NISTIR 6806

\title{
Project-Oriented Life-Cycle Costing Workshop for Energy Conservation in Buildings
}

Sieglinde K. Fuller

Amy S. Rushing

Gene M. Meyer

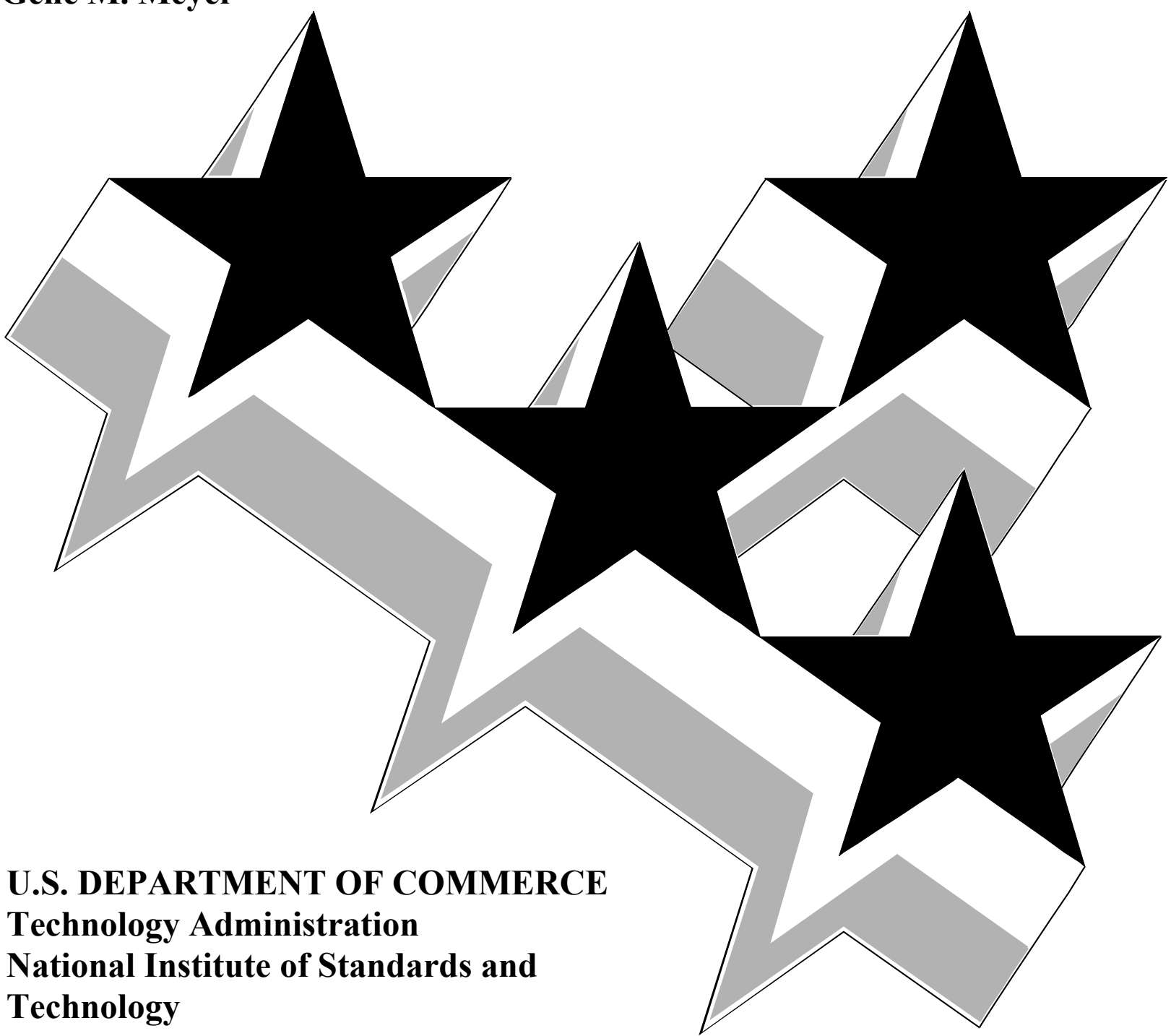

Prepared for:

United States Department of Energy

Federal Energy Management Program 



\section{Project-Oriented Life-Cycle Costing Workshop For Energy Conservation in Buildings}

Sieglinde K. Fuller

Amy S. Rushing

Office of Applied Economics

Gene M. Meyer

Kansas State University

September 2001

Building and Fire Research Laboratory

National Institute of Standards and Technology

Gaithersburg, MD 20899

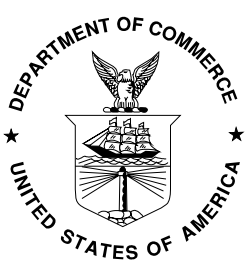

U.S. Department of Commerce

Donald L. Evans, Secretary

National Institute of Standards and Technology

Karen H. Brown, Acting Director
Sponsored by:

The Federal Energy Management Program

U.S. Department of Energy

Washington, DC 20585

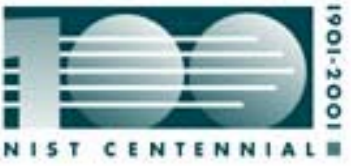





\section{Disclaimer}

Use of Non-Metric Units in NIST Internal Report No. 6806

The policy of the National Institute of Standards and Technology is to use metric units of measurement in all its publications. NISTIR 6806 is intended for a workshop audience that deals with energy projects for buildings and building systems. In construction-related industries in North America certain non-metric units are so widely used instead of metric units that it is more practical and less confusing to include in this workbook only measurement values for customary units. 


\section{Table of Contents}

Table of Contents ...............................................................................................................

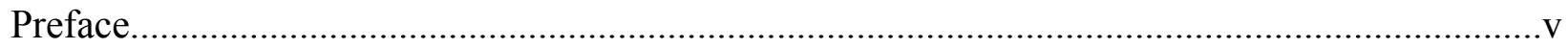

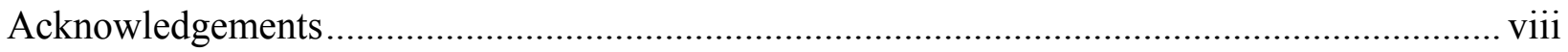

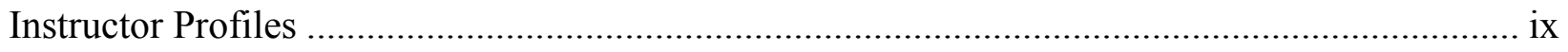

Workshop Objectives ...................................................................................................

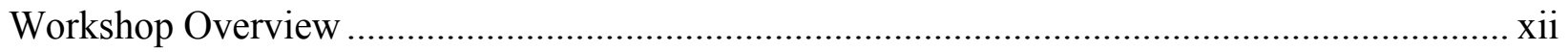

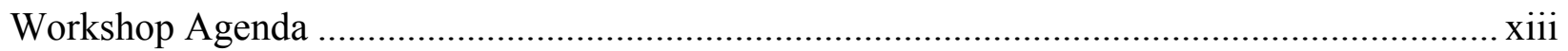

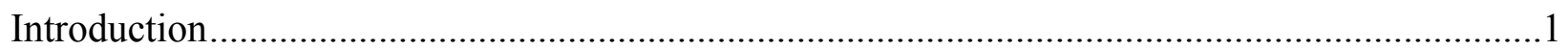

Module A: Review of LCC Method ................................................................................. A A

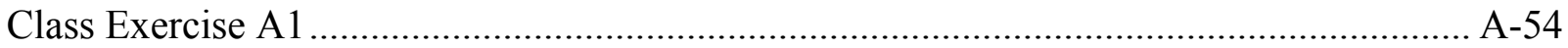

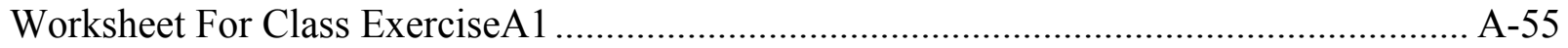

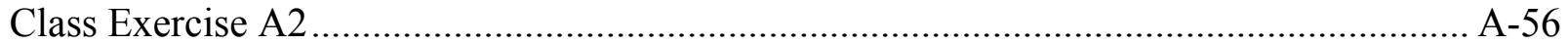



Solution to Class Exercise A1 ................................................................................... A-58

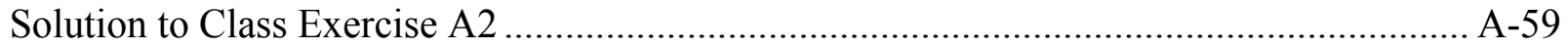

Summary of the Life-Cycle Costing Method ................................................................. A-60

Module B: NIST LCC Software: Overview and BLCC5 ….................................................

Module C: Fuel Switching and Phased-In Capital Replacements ............................................1

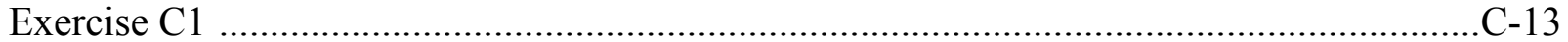

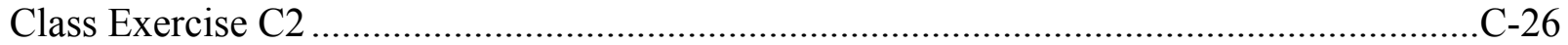



Module D: Replacement of Functional Systems to Improve Energy Efficiency.................... D-1

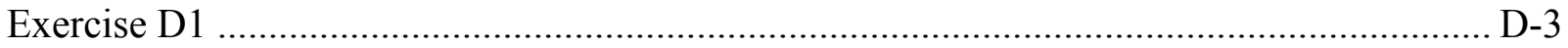

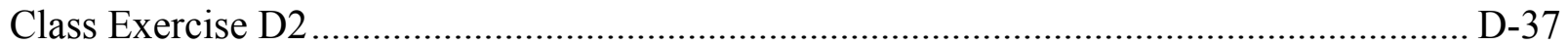

Solution to Class Exercise D2 …................................................................................ D-38

Module E: Replace Chiller or Purchase Chilled Water ...................................................... E-1



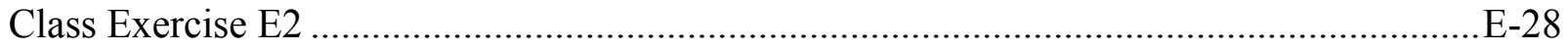

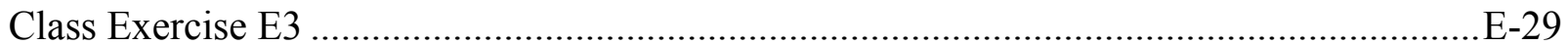

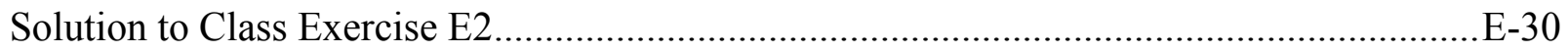

Solution to Class Exercise E3 .......................................................................................... 
Module F: Evaluation of Alternative Financing Contracts................................................

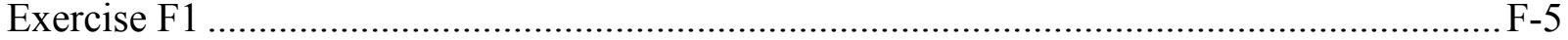

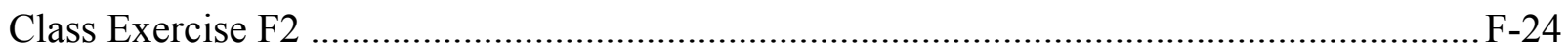

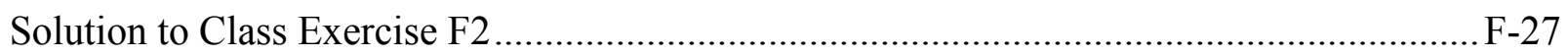

Module G: Class Examples............................................................................................ G-1

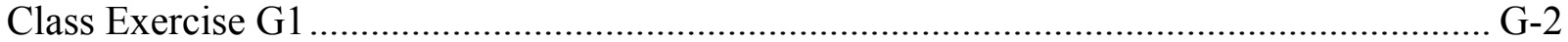

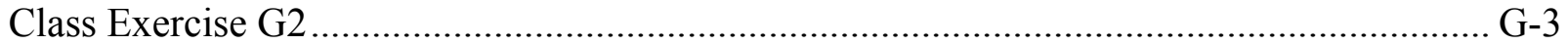

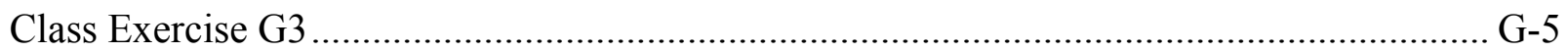

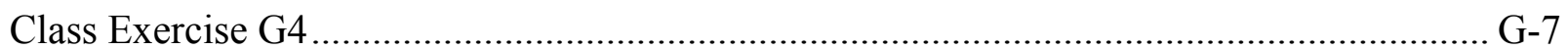



Solution to Class Exercise G2 …................................................................................ G-13

Solution to Class Exercise G3 …................................................................................. G-23

Solution to Class Exercise G4 .................................................................................... G-30

Economic Measures of Evaluation and Their Uses ......................................................... EM-1

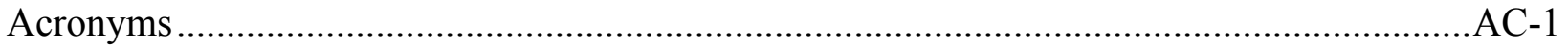

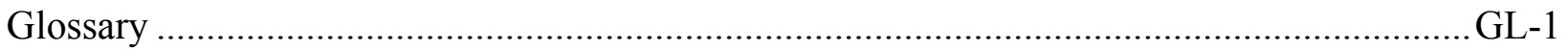

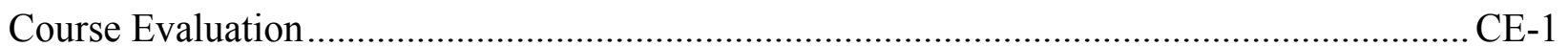




\section{Preface}

This student manual for the Project-Oriented Life-Cycle Costing Workshop for Energy Conservation in Buildings is a workbook for a two-day course on life-cycle costing developed by the National Institute of Standards and Technology (NIST) for the U.S. Department of Energy (DOE), Federal Energy Management Program (FEMP). The methodology and procedures in this manual are consistent with 10 CFR Part 436A and its amendments, which provide guidelines for the economic analysis of investments in energy and water conservation and renewable energy projects for federal buildings. These guidelines are explained in detail in Life-Cycle Costing Manual for the Federal Energy Management Program, Handbook 135, 1995 edition. The methodology is also consistent with American Society for Testing and Materials (ASTM) Standards on Building Economics, in particular ASTM Standard Practices E917, E964, E1057, E1074, E1121, and E1185.

The Project-Oriented LCC Workshop is one of three workshops conducted by NIST to provide energy managers with the knowledge and skills needed to perform quickly and correctly economic analyses required for building-related capital investments. The analytical methodology presented is equally useful for government and private-sector investment decisions. The Basic Life-Cycle Costing Workshop takes the participant through the steps of an LCC analysis, explains in detail the underlying theory of present-value analysis, and integrates it with the FEMP criteria. The ProjectOriented LCC Workshop builds on the basic workshop, focuses on the use of BLCC computer programs, and applies the LCC methodology to more complex issues. The third workshop is a twohour, interactive distance teaching workshop that introduces the elements of LCC analysis to participants at downlink sites across the U.S.

This student manual is organized into seven teaching modules. The workshop begins with a thorough review of LCC principles and 10 CFR 436 criteria. Each of the remaining modules is based on a topic that has emerged from past life-cycle costing workshops and the consulting activities of the Office of Applied Economics at NIST deemed of special interest to energy managers. The teaching material is organized around a representative example of an LCC analysis. A group exercise at the end of each module reinforces the students' knowledge gained during the presentation.

Visual materials (slides) used in the workshop are printed in the manual in the order they are presented to facilitate note taking. These visual materials are updated annually to reflect changes in the federal discount rate and projected energy price escalation rates used in federal LCC analyses of energy and water conservation projects.

Other materials used in the LCC workshop include the following:

(1) Energy Price Indices and Discount Factors for Life-Cycle Cost Analysis, Annual Supplement to NIST Handbook 135 and NBS Special Publication 709, National Institute of Standards and Technology, NISTIR 85-3273.

This report, which is updated annually, provides current DOE and OMB discount rates, projected energy price indices, and corresponding discount factors needed to estimate the present value of future energy and non-energy project-related costs. Request the latest edition when ordering.

NIST "Building Life-Cycle Cost" (BLCC) Computer Programs, BLCC5 and BLCC4, National Institute of Standards and Technology. These programs use as default values the same 
discount factors and energy price projections that underly the discount factor tables in the Annual Supplement. Use the latest BLCC versions, which are available at the DOE web site (see below).

The BLCC5 program is a windowed version of the DOS-based BLCC4. It is programmed in Java, uses an xml file format, and is thus platform-independent. The BLCC5 User's Guide is part of its Help system. BLCC5 has two modules:

(1) Module for Agency-Funded Projects

for LCC analyses of projects funded from direct appropriations.

(2) Module for Financed Projects

for LCC analyses of projects financed through ESPC or Utility Contracts as authorized by

Executive Order 13123 (6/99).

Other user-specific modules now in BLCC4 (e.g., for MILCON analyses, OMB analyses, and private-sector analyses, including taxes) will be transferred to BLCC5 as funding becomes available.

NIST BLCC programs provide comprehensive economic analysis capabilities for the evaluation of proposed capital investments that are expected to reduce the long-term operating costs of buildings and building systems. They compute the LCC for project alternatives, compare project alternatives in order to determine which has the lowest LCC, perform annual cash flow analysis, and compute net savings (NS), savings-to-investment ratio (SIR), adjusted internal rate of return (AIRR), and Payback Period (PB) for project alternatives over their designated study period. The BLCC programs can be used by federal, state, and local government agencies, as well as by the private sector (BLCC4). In their application to federal energy conservation and renewable energy projects, BLCC5 and BLCC4 are consistent with

- $\quad$ NIST Handbook 135, and the federal life-cycle cost methodology and procedures described in 10 CFR 436A,

- Circular A-94, and the

- Tri-Services Memorandum of Agreement on Criteria/Standards for Economic Analysis/LifeCycle Costing for MILCON Design.

In their application to private-sector and non-federal public-sector projects, they are consistent with ASTM standards for building economics.

The Annual Supplement to Handbook 135 can be downloaded from the DOE/FEMP web site at www.eren.doe.gov/femp (click on icon Technical Assistance and go to Analytical Software Tools).

Handbook 135 can be downloaded from the NIST web site at www.nist.bfrl.gov/oae/publications/handbooks/135.html. 
The latest versions of BLCC5 and BLCC4, associated programs, and user guides can be downloaded from the DOE/FEMP web site at

www.eren.doe.gov/femp (click on icon Technical Assistance and go to Analytical Software Tools).

To order diskettes of BLCC4 and associated programs and hard copies of the above publications, call the FEMP Help Desk:

Energy Efficiency and Renewable Energy Clearing House

(800) DOE-EREC (800-363-3732)

or write or fax your order to

U.S. Department of Energy

Federal Energy Management Program, EE-90

1000 Independence Avenue, S.W.

Washington, DC 20585-0121

Fax: (202) 586-3000

BLCC4 may also be purchased from the following vendors:

FlowSoft

5 Oak Forest Court

Saint Charles, MO 63303-6622

(636) 922-FLOW (3569)

www.flowsoft.com

Energy Information Services

P.O. Box 381

St. Johnsbury, VT 05819-0381

(802) 748-5148 


\section{Acknowledgements}

The authors are grateful to Dr. Robert Chapman and to Dr. Saul Gass for their review of this manual. Thanks are also due to the many workshop participants whose comments have been helpful in developing the course and the manual. The authors are especially indebted to Mr. Steven Petersen, formerly with the Office of Applied Economics, who initiated this effort and designed the first edition of this manual. J'aime Maynard assembled the latest revisions to the manuscript and managed its production. 


\title{
Instructor Profiles
}

\section{Sieglinde (Linde) K. Fuller, Ph.D}

Economist, Office of Applied Economics

Building and Fire Research Laboratory

National Institute of Standards and Technology

sieglinde.fuller@nist.gov

Dr. Fuller joined NIST's Office of Applied Economics in 1979. Her areas of expertise include benefit-cost analysis, economic impact studies, and the pricing of publicly supplied goods and services. As project leader of the NIST/DOE collaborative effort to promote energy and water conservation, she has been involved in developing techniques, workshops, instructional materials, and computer software for calculating the life-cycle costs and benefits of energy and water conservation projects in buildings, in accordance with federal legislation. She has participated in OAE projects to estimate the economic impacts of BFRL's research on U.S. industries and the return on BFRL's research investment dollars. Her doctoral studies focused on a public-sector pricing model in the Boiteux tradition, which calculates optimal prices and production plans for goods and services supplied by government agencies. She applied the model to NIST's Standard Reference Materials. Dr. Fuller has published manuals, reports, and articles related to these activities. In 1998 she was selected as a Twenty-First Century Citizenship Pioneer in DOE's "You Have the Power" Campaign.

Prior to her academic and professional work in economics, Dr. Fuller studied languages and linguistics in Germany and worked as an accredited translator and interpreter for industry representatives to the European Common Market, at trade exhibitions, and for commercial enterprises in Germany, Canada, and France.

\author{
Amy S. Rushing \\ Computer Specialist, Office of Applied Economics \\ Building and Fire Research Laboratory \\ National Institute of Standards and Technology \\ amy.rushing@nist.gov
}

Ms. Rushing joined the Office of Applied Economics in May 1997. Her major interests are computer programming and web site design. Currently she is using Java to update two DOS-based economic decision software tools to make the software more user-friendly. The first tool provides vehicle acquisition decision support, and the second is used for performing life-cycle costing of energy conservation projects in federal buildings. In addition, she is providing technical support for economic impact assessments of research related to cybernetic building systems and the computerintegrated construction environment.

Prior to joining the OAE staff, Ms. Rushing worked at Hood College utilizing her knowledge of computers to assist faculty, staff, and students. She also served as an intern at Frederick County Public Schools Technology Services where she initiated the design effort for the Frederick County Public Schools web site. 
Ms. Rushing programs in $\mathrm{C}++$ and Java. She is also proficient in HTML and web site design. In addition to her academic training, she has completed computer training courses in HTML, Java, and the design of user-interfaces.

\section{Gene M. Meyer, PE}

Engineering Extension Program

Kansas State University

gmeyer@ksu.edu

Mr. Meyer is an instructor with Engineering Extension at Kansas State University. Mr. Meyer's background includes seven years as a consulting engineer doing power plant design, and for the last 18 years he has assisted business and industry with energy and environmental issues. His areas of expertise include building HVAC systems, lighting, boiler operations and maintenance, solar design, and economic analysis. Meyer has taught building life-cycle cost analysis classes for the states of Ohio, Montana, Iowa, and Kansas; assisted with numerous FEMP BLCC classes; and has provided short courses on life-cycle cost analysis for the American Society of Heating, Refrigerating, and Air-Conditioning Engineers.

Meyer has a B.S. in mechanical engineering from the University of Kansas and an M.S. in mechanical engineering from Kansas State University. He is also a registered professional engineer in Kansas and Missouri. 


\section{Workshop Objectives}

Know how to use economic analysis to improve capital investment decisions related to energy and water conservation and renewable energy projects in buildings

Know the common methods and assumptions required for life-cycle cost analyses of energy- and water-related investments in federal buildings

Know how to use the BLCC programs for life-cycle cost analysis 


\section{Workshop Overview}

The workshop begins with a review of the LCC principles that are the subject of the Basic LCC Workshop. The elements of performing a life-cycle cost evaluation are explained. Emphasis is placed on clarifying those issues that often confuse practitioners. Issues include why it is necessary to adjust cash flows for the time-value of money and how to do it, how to estimate costs and savings, and how to handle inflation. Students are shown, step-by-step, how to compute Life-Cycle Costs, Net Savings, and the Savings-to-Investment Ratio. Federal criteria for performing economic evaluations of energy-related building projects are presented. The NIST LCC software is introduced with focus on the windowed version BLCC5. The course uses BLCC5 examples to address specific topics of interest to LCC practitioners, such as how to structure for LCC analysis projects that require

- $\quad$ fuel switching and phased-in capital replacements

- $\quad$ replacement of functional systems

- decisions whether to replace equipment or purchase services, and

- $\quad$ evaluation of an alternative financing contract.

The issue of uncertainty is discussed and guidance is given on how to deal with it in an LCC analysis. Exercises are provided on each topic, to be solved by student teams. 


\section{Workshop Agenda}

\section{Topic}
A. Review of LCC Method
B. NIST LCC Software: Overview and BLCC5
C. Fuel Switching and Phased-In Capital Replacements
D. Replacement of Functional Systems to Improve Energy Efficiency
E. Replace Chiller or Purchase Chilled Water
F. Evaluation of Alternative Financing Contracts
G. Class Examples 


\section{Introduction}

\section{Why this course}

The energy crisis of the 1970s, higher energy prices, and environmental concerns focused our attention on the critical need to include energy conservation as a major performance objective in the design or rehabilitation of buildings. In the last three decades, the Federal Government, as owner and operator of over a half-million buildings and the nation's largest user of energy, has played a leadership role in improving the energy efficiency of our nation's building stock. Through energy conservation alone, the Government has been able to save nearly a billion dollars a year between 1985 and 1994, at a savings-to-investment ratio of 5:1 and an internal rate of return of $25 \%$. More recently, water conservation in buildings and the use of renewable energy and green building materials have also been included in the Government's goal of ensuring efficient resource allocation.

Congress and the President, through legislation and executive order, have mandated energy and water conservation goals for federal buildings and have required that these goals be met using costeffective measures. These measures include both improved operating procedures and the incorporation of energy and water conservation features in the design of new and existing buildings. The primary criterion mandated by Congress and the President for assessing the cost-effectiveness of energy and water conservation measures is minimization of life-cycle costs. They have also instructed the Federal Government to make available to the public and private sector methods, computational tools, and data developed in the Federal Energy Management Program.

\section{Scope}

This workshop is complementary to the Basic LCC Workshop, which is theory-oriented. This workshop focuses more on project analysis and the use of LCC computer software. Each of the examples discussed provides a different insight into the application of economic analysis to energy and water conservation investments in buildings. The examples will also demonstrate how to structure an analysis for solution using the NIST BLCC computer programs.

The principles of economic evaluation taught in the Basic LCC Workshop, and reviewed at the beginning of this workshop, are applicable to investment decisions both in the public and private sectors. The decisions most relevant to building-related investments are (1) Is the higher initial cost of a project justified by the lower operating costs in later years? and (2) Of several potential alternative investments, which is the most economical in the long run? While this course focuses on investments in energy conservation and renewable resources in federal buildings, either agencyfunded or financed through energy services companies or utility energy services companies, the principles are equally applicable to projects undertaken by state and local governments, non-profit organizations, and for-profit companies and corporations. 


\begin{abstract}
About this manual
The manual is intended as both an in-class workbook and as a future source of reference and review. It is divided into seven modules by subject matter. The subject matter is discussed by way of sample analyses performed in BLCC5, the windowed version of the NIST LCC software. At the end of Module A, there is a summary of the LCC principles reviewed in the first lecture. For all other modules an exercise is provided to reinforce the material discussed in the lecture and to give students hands-on experience with BLCC5. Students are encouraged to work in small groups when solving these classroom exercises. The solution to each classroom exercise is included at the end of each corresponding module in the form of BLCC5 reports.
\end{abstract}





\section{Module A}

\section{Review of LCC Method}

Objectives: Upon completion of this module, you will understand

- rationale for Life-Cycle Cost Analysis

- basic LCC methodology

- federal LCC rules

- interpretation of analysis results 


\section{Basic Economic Criterion for Capital}

Investments that Reduce Future Operating

\section{Costs}

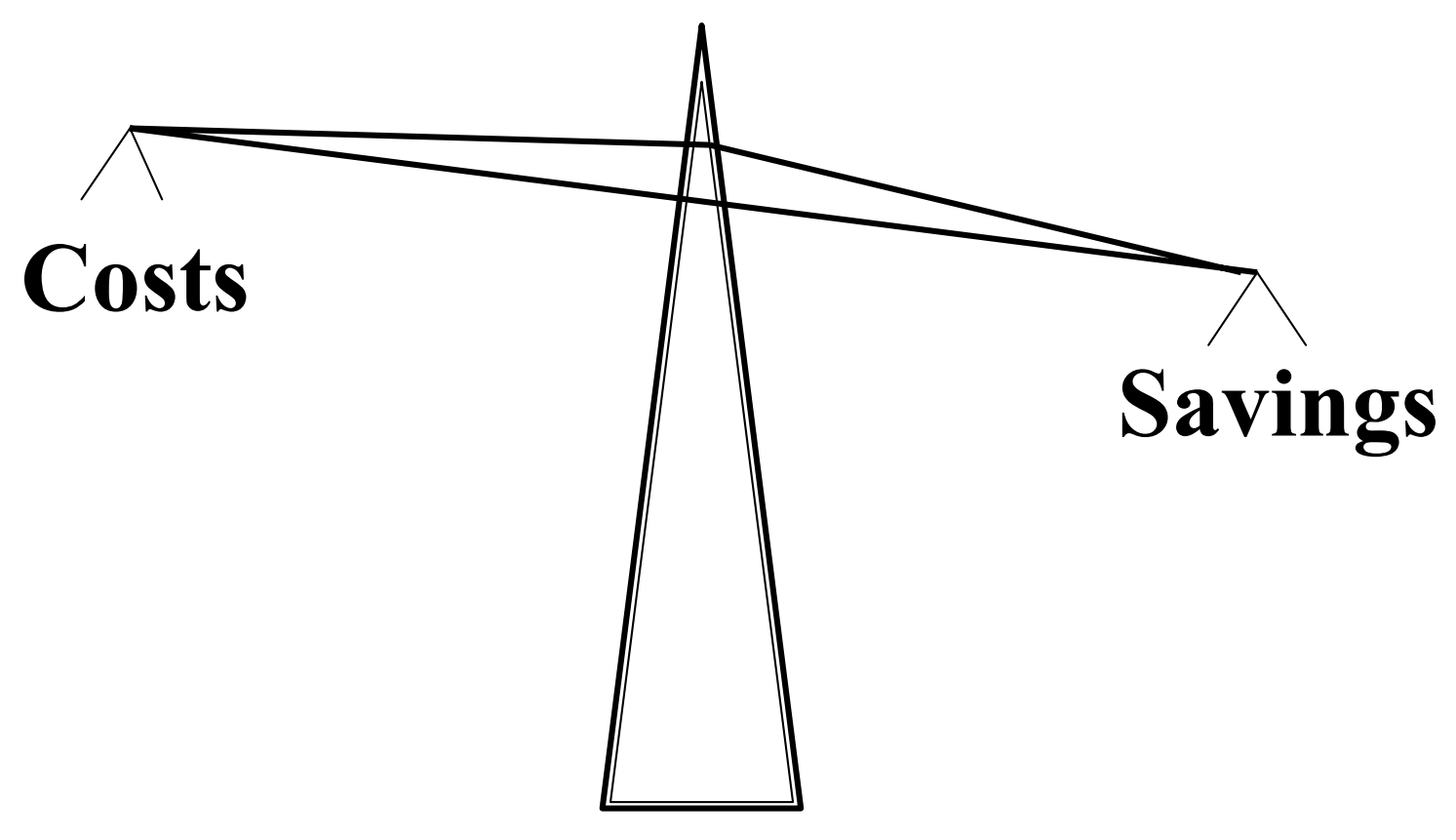

Savings must be greater than costs! 


\section{Life-Cycle Costs of Two Alternatives}

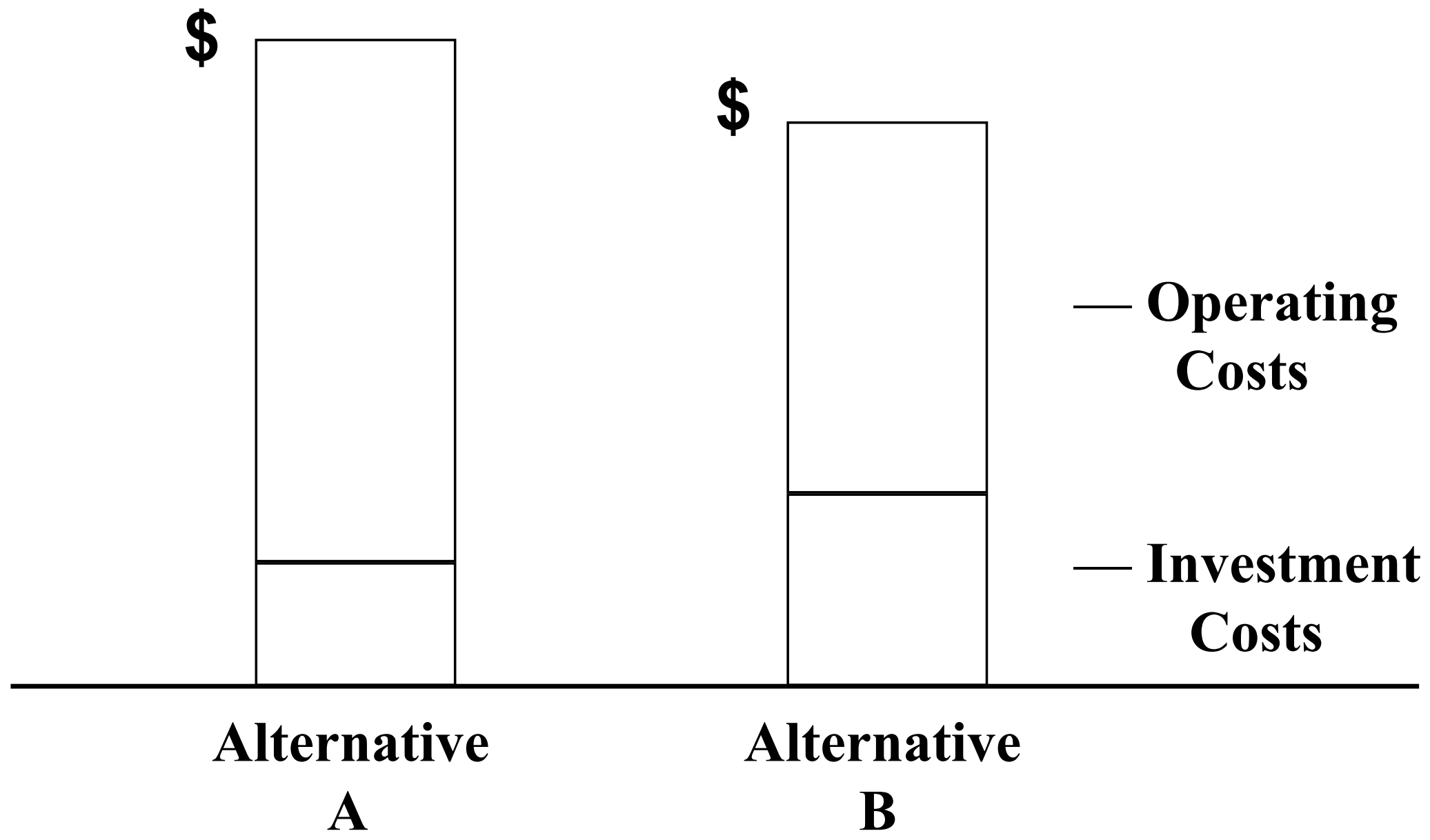




\section{Total Life-Cycle Cost is Minimized}






\section{Net Savings are Maximized}

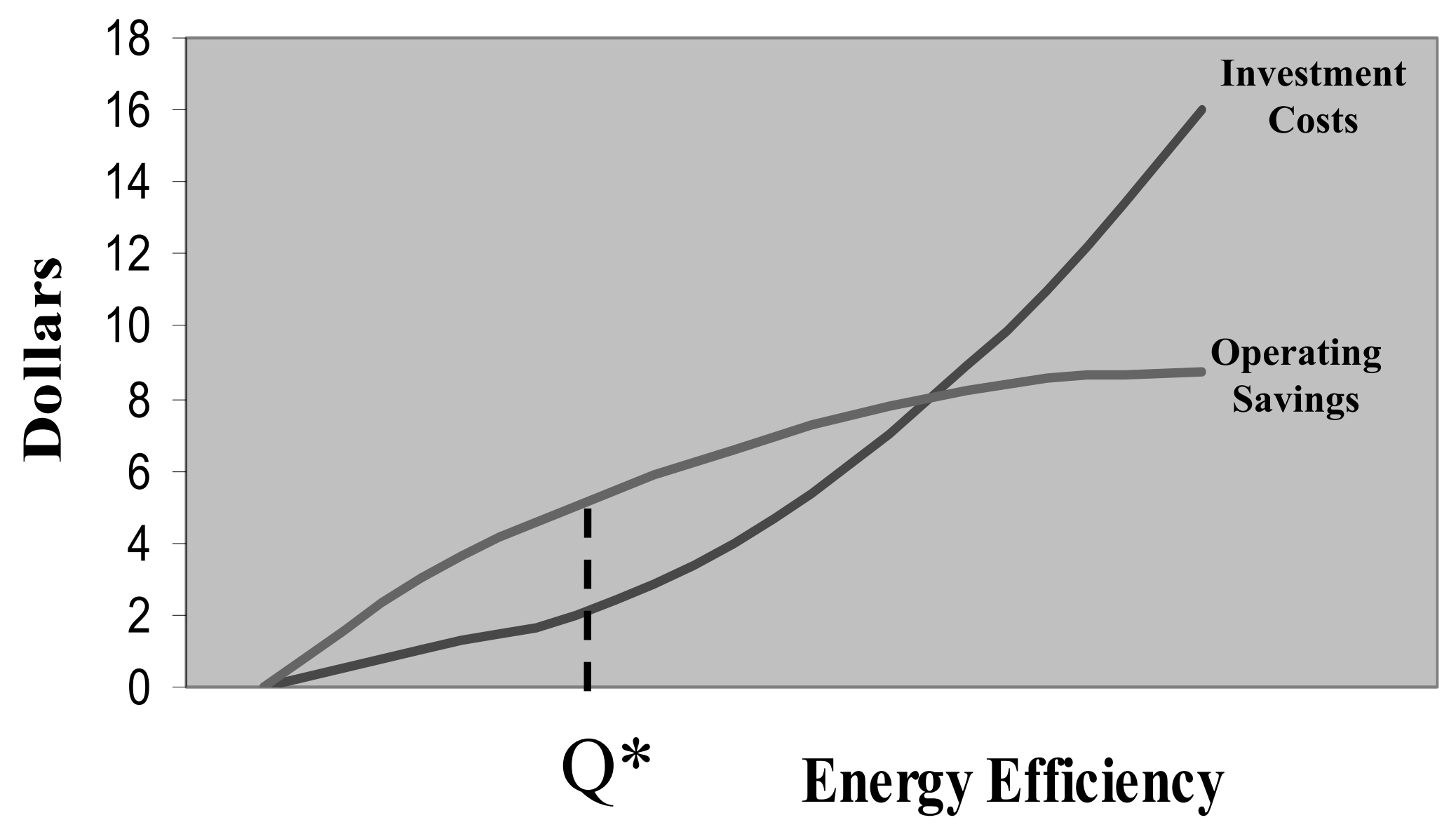




\section{Incremental Savings Equal Incremental Costs}






\section{Types of Decisions}

- Accept/reject projects

- Optimal energy efficiency level

- Optimal system selection or design

- Optimal combination of

interdependent systems

- Prioritization of independent projects 


\section{Life-Cycle Cost Analysis}

LCCA is

- a method of economic analysis that sums all relevant project costs over a given study period in present-value terms.

- most relevant when selecting among mutually exclusive project alternatives that provide the same functional performance but have different initial costs, OM\&R costs, and/or expected lives. 


\section{Typical Project Costs}

- Investment-related:

- Acquisition costs

- Replacement costs

- Residual value (resale or disposal cost)

- Operating-related:

- Operation, maintenance, and repair costs

- Energy and water costs

- Contract-related costs (for financed projects)

Generally, only amounts that are different need to be considered when comparing mutually exclusive alternatives. 


\section{The Study Period}

The study period

- is the length of time over which an investment is analyzed based on

- the expected life of the project and/or

- the investor's time horizon.

- Base Date: analysis date to which all cash flows are discounted.

- Service Date: date when building or system is occupied or becomes operational.

- Study period must be the same for all alternatives. 


\section{Study Period}

Base Date


Phased-in Planning/Construction/Implementation Period 


\section{Adjusting for Different System Lives}

SYSTEM I: 15 YRS

Residual

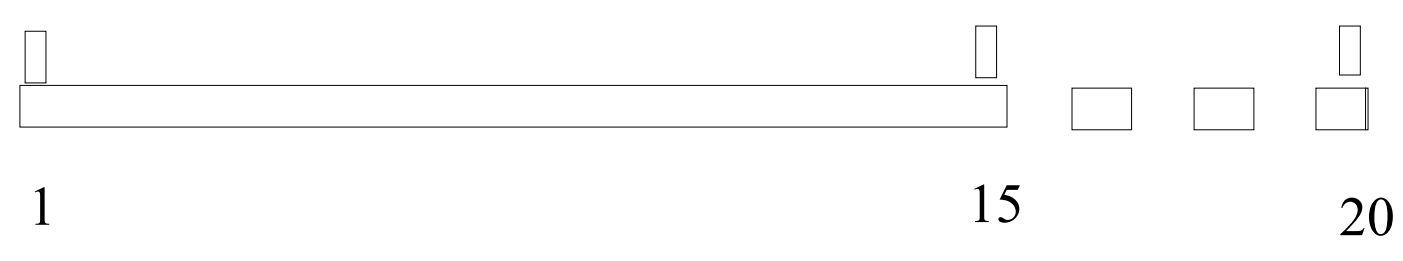

SYSTEM II: 20 YRS

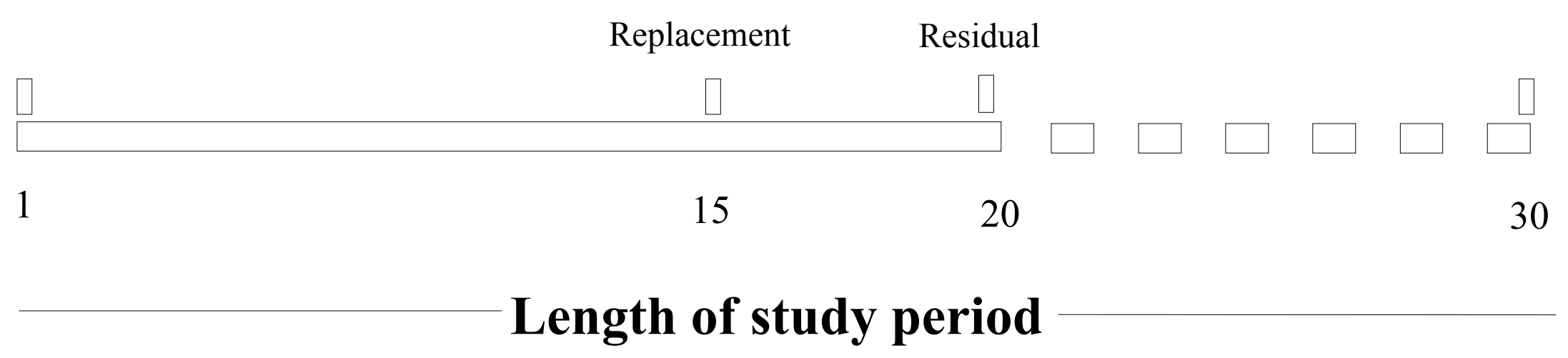




\section{Present Value and Discounting}

A present value amount

- is the equivalent value to an investor, as of the base date, of a cash amount paid or received at a future date.

The present value of a future amount

- is found by discounting;

discounting adjusts for the investor's time-value of money.

The discount rate

- is the interest rate that makes an investor indifferent between cash amounts received or paid at different points in time. 


\section{Life-Cycle Cost}

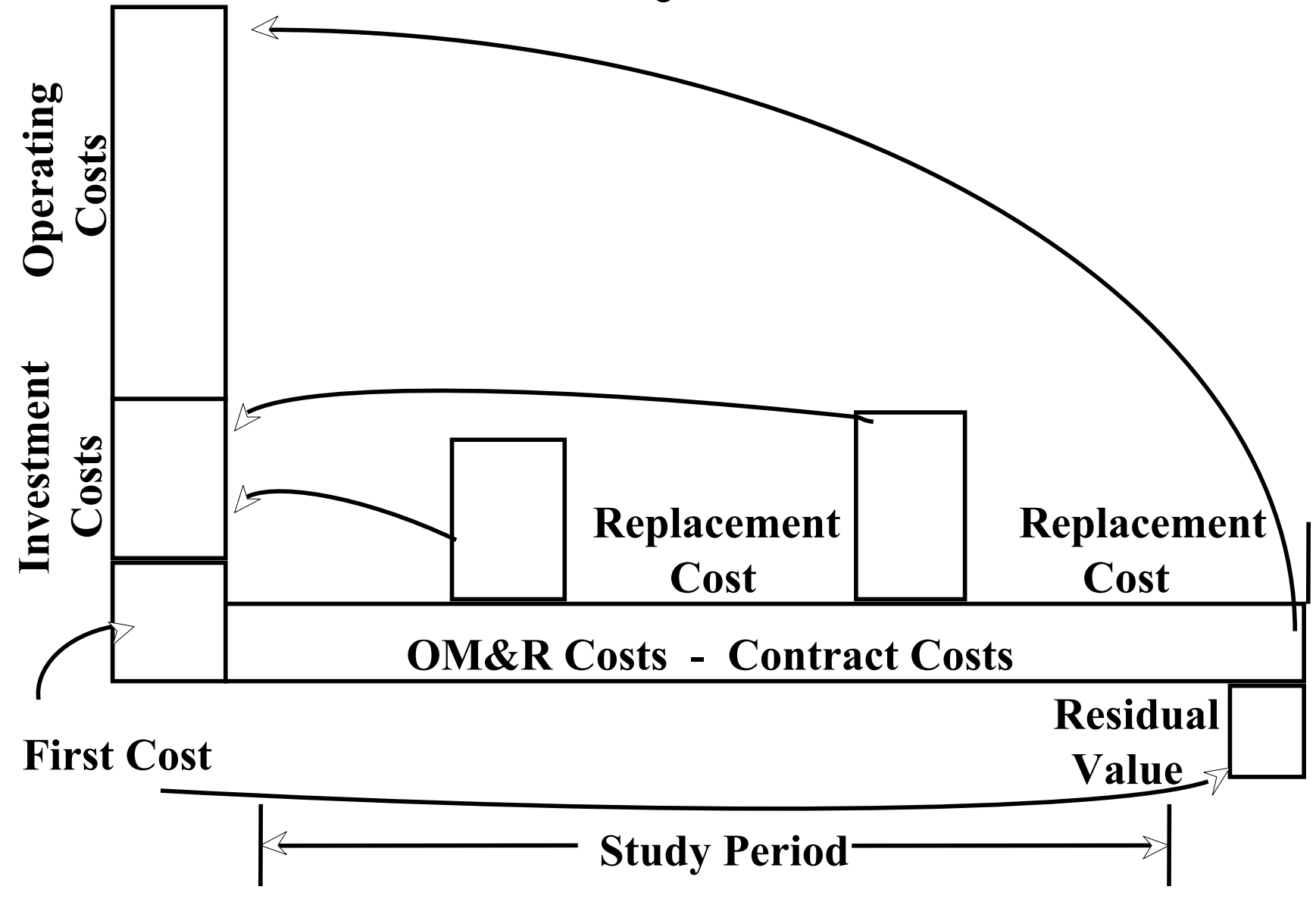




\section{Converting future amounts to present value:}

$$
P V=C_{t} \times \frac{1}{(1+d)^{t}}
$$

$$
L C C=\sum_{t=0}^{n} \frac{C_{t}}{(1+d)^{t}}
$$

where $n=$ length of study period. 


\section{Useful Discount Factors}

(1) Single present value (SPV) factor for one-time amounts or non-annually recurring amounts:

$$
P V=F_{t} \times \operatorname{SPV}_{(t, d)}
$$

(2) Uniform present value (UPV) factor for uniform annual amounts:

$$
\mathbf{P V}=\mathbf{A}_{0} \times \mathbf{U P V}_{(\mathrm{n}, \mathrm{d})}
$$

where $A_{0}=$ annual amount at base-date prices 


\section{Useful Discount Factors (cont.)}

(3) Modified uniform present value (UPV*) factor for changing annual amounts

$$
P V=A_{0} \times U^{*}{ }_{(\mathrm{n}, \mathrm{d}, \mathrm{e})}
$$




\section{DOE Energy Price Projections}

- DOE energy price escalation rates vary

- by region (census region)

- by fuel type (elec., oil, gas, LPG, coal)

- by rate (residential, commercial, industrial)

- by year 


\section{Summary of Present Value Factors}

Single future amount (year $t)$

$$
P V=F_{t} \times S P V_{(t, d)}
$$



Recurring annual amount (over n years) $P V=A_{0} \times U P V_{(n, d)}$

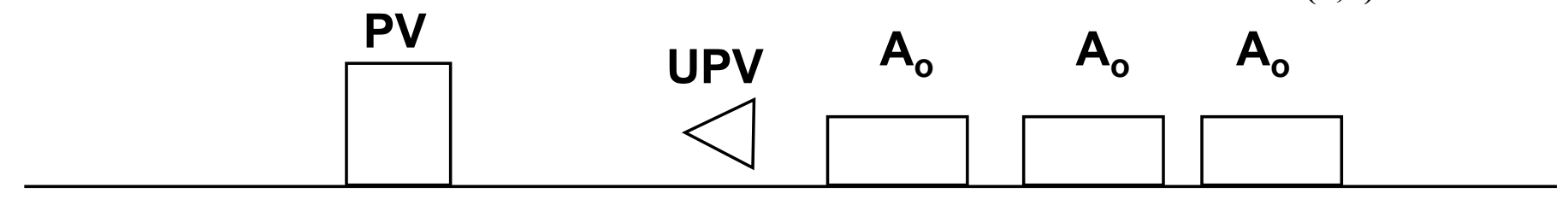

Changing annual amount (over n years) $P V=A_{0} \times U V^{*}{ }_{(n, d, e)}$






\section{Single Present Value Factor}

Example: Find the present value of $\$ 1,000$ received at the end of year 10 when the discount rate is $3.3 \%$ (table A-1, Annual Supplement to HB135).

$$
\begin{aligned}
P V & =F_{t} \times S P V \\
P V & =\$ 1,000 \times S P V \\
& =\$ 1,000 \times 0.723=\$ 723
\end{aligned}
$$




\section{Uniform Present Value (UPV) Factor}

Find the present value of an annually recurring operating cost of $\$ 1,000$ each year for 10 years when the discount rate is $3.3 \%$ (table A-2, Annual Supplement to HB135).

$$
\begin{aligned}
P V & =A_{0} \times U P V \\
P V & =\$ 1,000 \times U P V \\
& =\$ 1,000 \times 8.40=\$ 8.3, n=10) \\
& \$ 8,400
\end{aligned}
$$




\section{Modified Uniform Present Value} (UPV*) Factor

Find the present value of an annually recurring operating cost of $\$ 1,000$ over 10 years, when this cost is expected to escalate at $2 \% / y r$ and the discount rate is $3.3 \%$ (table A-3a, Annual Supplement to HB135).

$$
\begin{aligned}
P V & =A_{0} \times U^{*} V^{*} \\
P V & =\$ 1,000\left(\text { annual) } \times U^{*}{ }_{(d=3.3, n=10, e=2 \%)}\right. \\
& =\$ 1,000 \times 9.33=\$ 9,330
\end{aligned}
$$




\section{FEMP UPV* Factor for Energy Costs}

Find the present value of an annually recurring electricity cost of $\$ 1,000$ over 10 years, given current DOE energy price escalation rates (Region 4, industrial rates) and the current DOE discount rate of 3.3\% (table Ba-4, Annual Supplement to HB135).

$$
\begin{aligned}
P V & =A_{0} \times U^{*} * \\
P V & =\$ 1,000 \times \mathrm{UPV}^{*}{ }_{(\mathrm{d}=3.3, \mathrm{n}=10, \text { electr., industrial, region } 4)} \\
& =\$ 1,000 \times 6.96=\$ 6,960
\end{aligned}
$$




\section{Sources of Discount Factors}

- Discount factors can be hand-calculated, computercalculated, or looked up.

- Sources:

- Annual Supplement to Handbook 135 (for federal projects)

- NIST DISCOUNT computer program, NISTIR 85-3273-xx

- Generic discount factor tables, NISTIR 89-4203

- Available from:

- DOE HELP Desk at 1-800-DOE-EREC (363-3732) or

- www.eren.doe.gov - Technical Assistance - Analytical Software Tools 


\section{Inflation Adjustment in LCCA}

\section{Definitions}

- Inflation: rate of increase of the general level of prices.

- Escalation: rate of increase in the price of a particular commodity.

- Differential escalation: rate of increase in the price of a particular commodity relative to the rate of increase in the general level of prices. 


\section{Inflation Adjustment in LCCA}

Definitions (cont.)

- Constant dollars: dollars of uniform purchasing power from year to year, exclusive of general inflation.

- Current dollars: dollars of purchasing power of year in which actual prices are stated, including general inflation. 


\section{Two Approaches for Dealing with Inflation}

- Exclude general price inflation:

- Specify all costs in constant dollars.

- Use a real discount rate (excluding inflation).

- Include general price inflation:

- Specify all costs in current dollars.

- Use a nominal discount rate (including inflation). Both approaches yield the same present values. 


\section{Comparing LCCs of Alternative Systems Requires a Common Analytical Perspective}

- Base date

- Service date

- Study period

- Discount rate

- Inflation assumption (or constant dollar analysis)

- Cost estimating method(s)

- Operational schedule

- Energy analysis method 


\section{Federal Criteria for LCC Analysis}

- Energy and Water Conservation Projects-10 CFR 436A/HB135

- DOE discount rate (updated annually), published in Annual Supplement to Handbook 135

- Maximum 25-year service period

- Local energy prices, metered energy quantities

- DOE energy price escalation rates

- Analysis usually in constant base-year dollars (i.e., excluding inflation), except for financed projects

- Other federal projects-OMB Circular A-94

- OMB discount rates, varying with length of study period and type of project

- No limit on study period 


\section{Example I: Central AC System Selection for Office Building}

Location:

Discount rate:

Fuel type:

Price:

Rate type:

Useful life:

Study period:

Base date:
Federal building, Washington, DC;

DOE Region 3

2001 FEMP discount rate: 3.3\% real (constant-dollar analysis)

Electricity

$\$ 0.08 / \mathbf{k W h}$, local rate as of base date

Commercial

20 years

20 years

June 2001 


\section{Base Case:}

\section{Conventional System w/o Computer Controls and Economizer}

- $\$ 103,000$ Initial investment costs

- $\quad \$ 12,000$ Replacement cost for fan at the end of year 12

- $\quad 33,500$ Residual value at the end of the 20-year study period

- $\$ 20,000$ Annual electricity costs $(250,000 \mathrm{kWh}$ at $\$ \mathbf{\$ 0 . 0 8 / k W h )}$

- \$ 7,000 Annual OM\&R costs 


\section{Cash-Flow Diagram for Base Case}
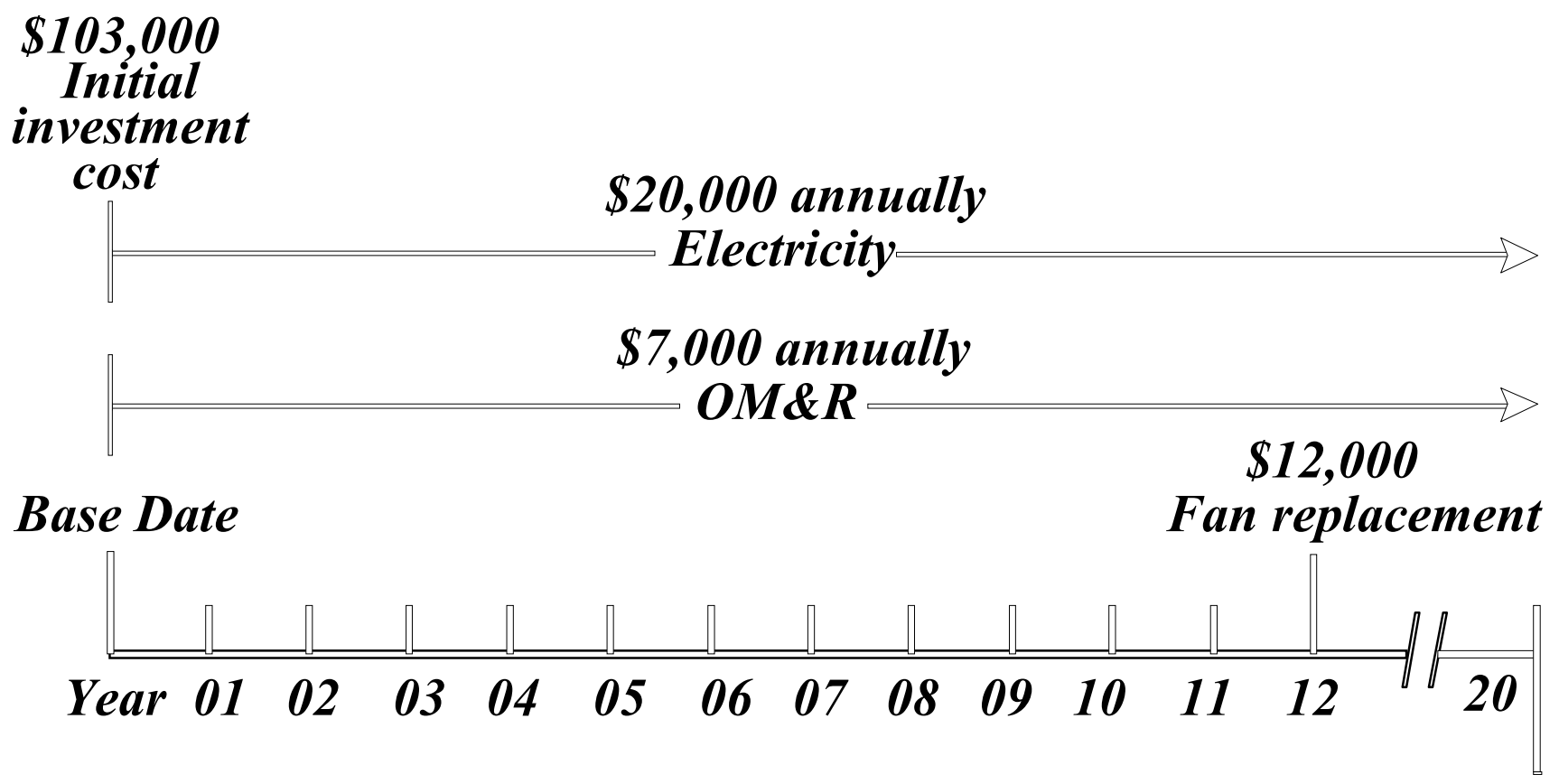


\section{LCC for Base Case (Conventional System)}

\begin{tabular}{|c|c|c|c|c|}
\hline $\begin{array}{c}\text { Cost Items } \\
\text { (1) }\end{array}$ & $\begin{array}{c}\text { Base Date } \\
\text { Cost } \\
\text { (2) }\end{array}$ & $\begin{array}{c}\text { Year of } \\
\text { Occurrence } \\
\text { (3) }\end{array}$ & $\begin{array}{l}\text { Discount } \\
\text { Factor } \\
\quad(4)\end{array}$ & $\begin{array}{l}\text { Present } \\
\text { Value } \\
(5)=(2) \times(4)\end{array}$ \\
\hline Initial investment & $\$ 103,000$ & Base date & $\begin{array}{l}\text { already in } \\
\text { present value }\end{array}$ & $\$ 103,000$ \\
\hline $\begin{array}{l}\text { Capital replacement } \\
\text { (fan) }\end{array}$ & $\$ 12,000$ & 12 & $\begin{array}{l}\text { SPV }_{12} \\
0.677\end{array}$ & $\$ 8,124$ \\
\hline Residual value & $(\$ 3,500)$ & 20 & $\begin{array}{l}\mathrm{SPV}_{20} \\
0.522\end{array}$ & $(\$ 1,827)$ \\
\hline $\begin{array}{l}\text { Electricity: } \\
250,000 \mathrm{kWh} \text { at } \\
\$ \mathbf{0 . 0 8} / \mathbf{k W h}\end{array}$ & $\$ 20,000$ & annual & $\begin{array}{l}U^{U P V}{ }^{*} \\
12.99\end{array}$ & $\$ 259,800$ \\
\hline OM\&R & $\$ 7,000$ & annual & $\begin{array}{l}\text { UPV }_{20} \\
14.47\end{array}$ & $\$ 101,290$ \\
\hline Total LCC & & & & $\$ 470,387$ \\
\hline
\end{tabular}




\section{Alternative Case:}

Energy-Saving System with Computer Controls and Economizer

- \$110,000 Initial investment costs

- \$12,500 Replacement cost for fan at the end of year 12

- $\$ 3,700$ Residual value at the end of the 20-year study period

- \$13,000 Annual electricity costs $(162,500 \mathrm{kWh}$ at $\$ \mathbf{0 . 0 8} / \mathbf{k W h})$

- \$ 8,000 Annual OM\&R costs 


\section{LCC for Alternative (Energy-saving system)}

\begin{tabular}{|c|c|c|c|c|}
\hline $\begin{array}{c}\text { Cost Items } \\
\text { (1) } \\
\end{array}$ & $\begin{array}{c}\text { Base Date } \\
\text { Cost } \\
\text { (2) }\end{array}$ & $\begin{array}{c}\text { Year of } \\
\text { Occurrence } \\
\text { (3) }\end{array}$ & $\begin{array}{l}\text { Discount } \\
\text { Factor } \\
\quad(4)\end{array}$ & $\begin{array}{l}\text { Present } \\
\text { Value } \\
(5)=(2) \times(4)\end{array}$ \\
\hline Initial investment cost & $\$ 110,000$ & Base date & $\begin{array}{l}\text { already in } \\
\text { present value }\end{array}$ & $\$ 110,000$ \\
\hline $\begin{array}{l}\text { Capital replacement } \\
\text { (fan) }\end{array}$ & $\$ 12,500$ & 12 & SPV $_{12} \quad 0.677$ & $\$ 8,462$ \\
\hline Residual value & $(\$ 3,700$ & 20 & $\mathrm{SPV}_{20} \quad 0.522$ & $(\$ 1,931)$ \\
\hline $\begin{array}{l}\text { Electricity: } \\
162,000 \mathrm{kWh} \text { at } \\
\$ 0.08 / \mathrm{kWh}\end{array}$ & $\$ 13,000$ & annual & $\mathrm{UPV}_{20}^{*} 12.99$ & $\$ 168,870$ \\
\hline OM\&R & $\$ 8,000$ & annual & $\mathbf{U P V}_{20} 14.47$ & $\$ 115,760$ \\
\hline Total LCC & & & & $\$ 401,161$ \\
\hline
\end{tabular}




\section{Lowest LCC}

LCC of Base Case : $\quad \$ \mathbf{\$ 4 0 , 3 8 7}$

LCC of Alternative: $\quad \$ 401,161$

Alternative with the lowest LCC

is the economic choice. 


\section{Uses of Life-Cycle Cost}

Types of Decisions

Accept /Reject

Optimal Performance

Optimal System/Design

Project Priority $\underline{\text { LCC }}$ Criterion

yes lowest LCC

yes lowest LCC

yes lowest LCC

no 


\section{Supplementary Economic Measures}

- Net Savings (NS)

- Savings-to-Investment Ratio (SIR)

- Adjusted Internal Rate of Return (AIRR)

- Discounted Payback (DPB) 


\section{Net Savings (NS)}

NS $=$ PV of operational savings minus PV of additional investment

$\begin{array}{ll}\mathbf{N S}_{\mathrm{Alt}} & =\mathbf{L C C}_{\mathrm{BC}}-\mathrm{LCC}_{\mathrm{ALT}} \\ \mathbf{N S}_{\mathrm{ALT}} & =\mathbf{\$ 4 7 0 , 3 8 7 -} \mathbf{\$ 4 0 1 , 1 6 1} \\ \mathbf{N S}_{\mathrm{ALT}} & =\mathbf{\$ 6 9 , 2 2 6}\end{array}$

Alternative with the highest NS is the economic choice. 


\section{Uses of Net Savings}

Types of Decisions

Accept/Reject

Optimal Performance

Optimal System/Design yes

Project Priority
$\underline{\mathrm{LCC}}$

yes

yes

no
Criterion

$>0$ / $<0$

maximize

maximize

- 


\section{Savings-to-Investment Ratio (SIR)}

SIR = Ratio of PV of operational savings to $P V$ of additional investment costs 


\title{
Savings-to-Investment Ratio
}

\author{
PV operational savings \\ SIR $=\overline{\text { PV of additional investment costs }}$
}

PV Operational savings $=\quad P V O \& M \operatorname{costs}_{B C}-P V O \& M \operatorname{costs}_{A L T}$ $P V \Delta$ Investment costs $=P V$ investment $_{A L T}-P V$ investment $_{B C}$

$$
\begin{aligned}
& \text { SIR }=\frac{(259,800+101,290)-(168,870+115,760)}{(110,000+8,462-1,931)-(103,000+8,124-1,827)} \\
& \operatorname{SIR}=\frac{76,460}{7,234}=10.6
\end{aligned}
$$




\section{Uses of Savings-to-Investment Ratio}

Types of Decisions

Accept /Reject

Optimal Performance

Optimal System/Design no

Project Priority



no

yes
Criterion

$>1 /<1$

descending

order

Meaningful SIR cannot be computed for financed projects. 
Adjusted Internal Rate of Return (AIRR)

$A I R R=$ Measure of performance of investment as a percentage yield, assuming reinvestment of cash flows at a given rate (r)

$A I R R=(1+r) S I R R^{1 / N}-1$

$=(1+0.033) 10.6^{1 / 20}-1$

$=16.2 \%$ 


\section{Uses of Adjusted Internal Rate of Return}

Types of Decisions

Accept/Reject

Optimal Performance no

Optimal System/Design no

Project Priority
$\underline{\mathrm{LCC}}$

yes

yes
Criterion

$>$ d $/<$ d

$-$

$--$

descending

order

Meaningful AIRR cannot be computed for financed projects. 


\section{Discounted Payback (DPB)}

DPB $=$ Minimum value of $n$, years, for which discounted savings in year $t$ are at least equal to additional initial investment costs 


\section{Discounted Payback for Alternative}

Base-year electricity savings: $\quad \$ \mathbf{\$ , 0 0 0}$ Base-year OM\&R savings: $\quad$ - $\$ 1000$ Additional Initial Investment: $\mathbf{\$ 7 , 0 0 0}$

$\begin{array}{cccr}\text { Year } & \text { Cumulative } & \Delta \text { Initial } & \begin{array}{c}\text { Cumulative } \\ \text { PV Net Savings }\end{array} \\ 1 & \text { PV Savings } & \text { Cost } & \text { PV No } \\ 2 & \$ \mathbf{5 , 6 1 0} & \mathbf{\$ 7 , 0 0 0} & \mathbf{\$ 1 , 3 9 0} \\ & \mathbf{1 0 , 9 7 0} & \mathbf{7 , 0 0 0} & \mathbf{3 , 9 7 0}\end{array}$

Discounted Payback occurs in year 2. 


\section{Uses of Discounted Payback}

Types of Decisions

Accept / Reject

Optimal Performance

Optimal System/Design no

Project Priority $\frac{\text { LCC }}{\text { yes }}$

no

no
Criterion

$\leq / \geq$ proj.life

$\boldsymbol{- a}$

므뭄

$--$

Meaningful DPB cannot be computed for financed projects. 


\section{Example II: CAC System Selection for Office Building with Planning/Construction Period}

- 2-year planning/construction period

- First half of investment cost incurred at end of year 1, second half at service date 


\section{Cash Flow Diagram for Base Case with P/C Period}

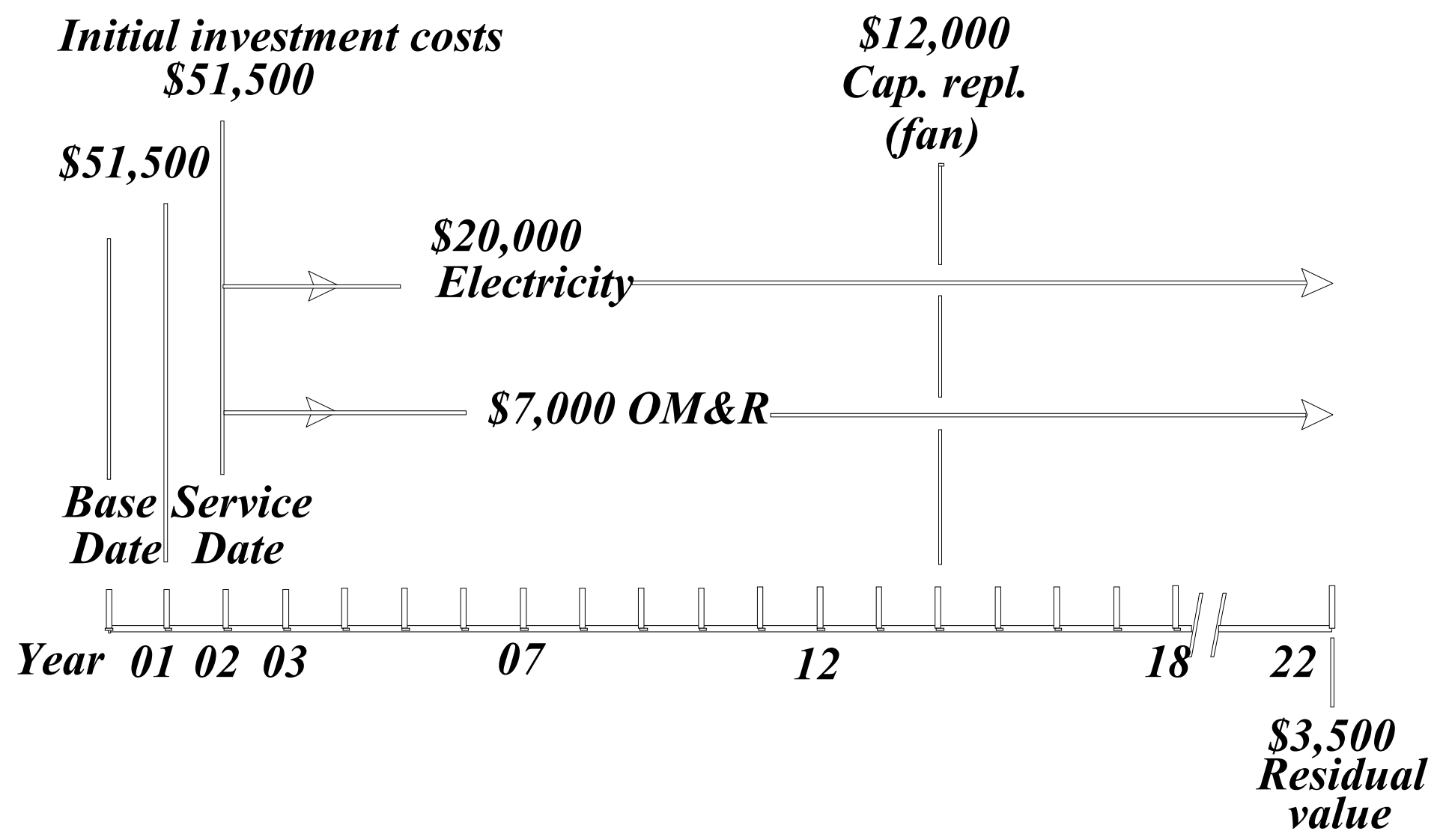




\section{LCC Calculation for Base Case with P/C Period}

\begin{tabular}{|c|c|c|c|c|}
\hline $\begin{array}{c}\text { Cost Items } \\
\text { (1) } \\
\end{array}$ & $\begin{array}{c}\text { Base Date } \\
\text { Cost } \\
(2) \\
\end{array}$ & $\begin{array}{c}\text { Year of } \\
\text { Occurrence } \\
(3)\end{array}$ & $\begin{array}{l}\text { Discount } \\
\text { Factor } \\
(4)\end{array}$ & $\begin{array}{l}\text { Present } \\
\text { Value } \\
(5)=(2) \times(4)\end{array}$ \\
\hline $\begin{array}{l}\text { Initial investment cost: } \\
1 \text { st Installment at } \\
\text { midpoint of construction }\end{array}$ & $\$ 51,500$ & 1 & $\mathrm{SPV}_{1}$ & $\$ 49,852$ \\
\hline $\begin{array}{l}\text { 2nd Installment at } \\
\text { beginning of service } \\
\text { period }\end{array}$ & $\$ 51,500$ & 2 & $\mathrm{SPV}_{2}$ & $\$ 48,256$ \\
\hline Capital replacement (fan) & $\$ 12,000$ & 14 & $\mathrm{SPV}_{14} \quad 0.635$ & $\$ 7,620$ \\
\hline Residual value & $(\$ 3,500)$ & 22 & $\mathrm{SPV}_{22} \quad 0.490$ & $(\$ 1,715)$ \\
\hline $\begin{array}{l}\text { Electricity: } \\
250,000 \mathrm{kWh} \text { at } \\
\$ 0.08 / \mathrm{kWh}\end{array}$ & $\$ 20,000$ & annual 1 ? & $\begin{array}{c}\mathrm{UPV}^{*}{ }^{22-2} \\
13.88-1.84=12.04\end{array}$ & $\$ 240,800$ \\
\hline $\mathrm{OM} \& \mathrm{R}$ & $\$ 7,000$ & annual & $\begin{array}{c}\mathrm{UPV}_{22-2} \\
15.47-1.91=13.56\end{array}$ & $\$ 94,920$ \\
\hline Total LCC & & & & $\$ 439,733$ \\
\hline
\end{tabular}




\section{LCC Calculation for Alternative with P/C Period}

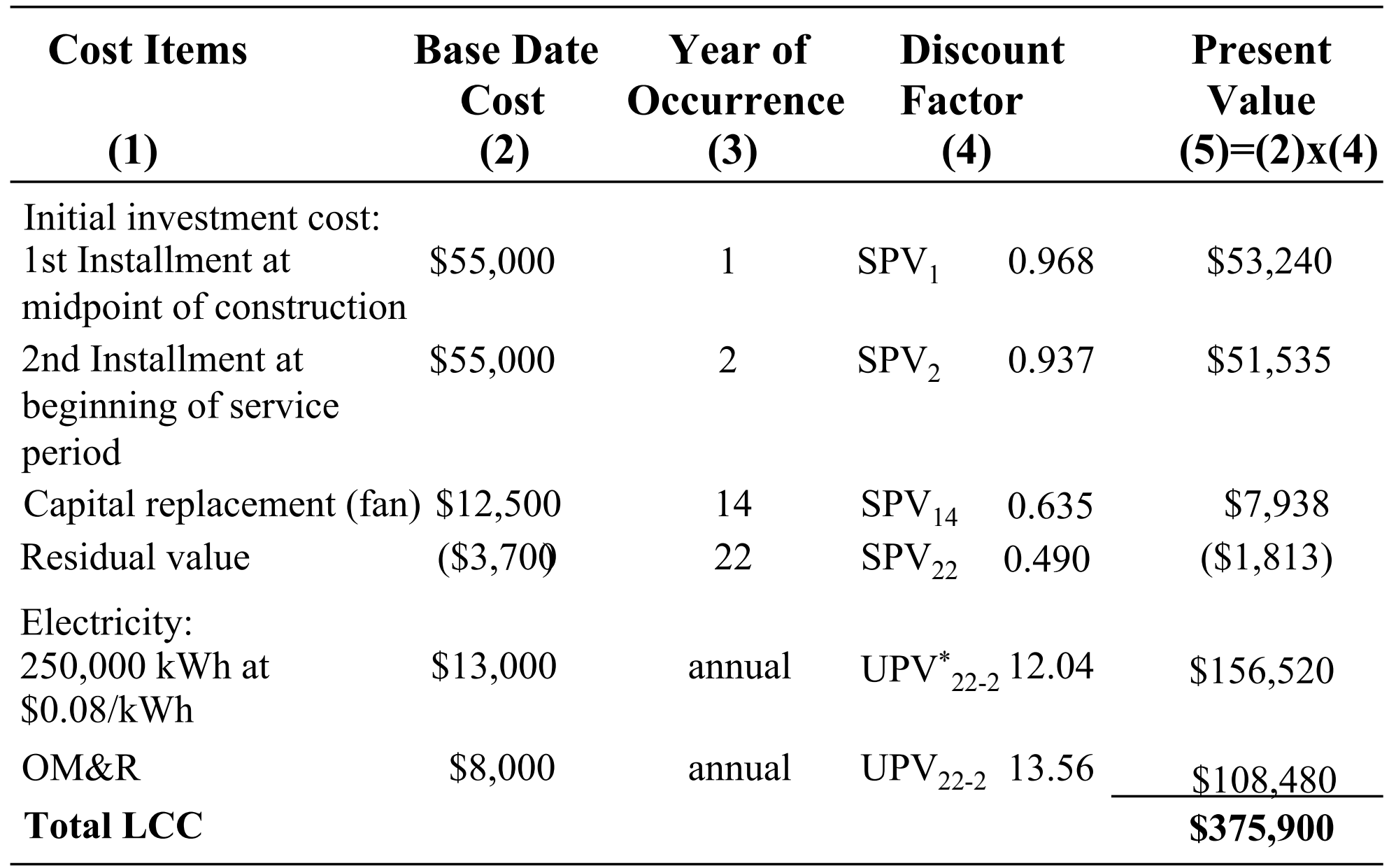




\section{Net Savings for Alternative with P/C Period}

$\mathrm{NS}_{\mathrm{Alt}}=\mathrm{LCC}_{\mathrm{BC}}-\mathrm{LCC}_{\mathrm{ALT}}$

$\mathrm{NS}_{\mathrm{ALT}}=\$ 439,733-375,900$

$\mathrm{NS}_{\mathrm{ALT}}=\$ 63,833$

Savings-to-Investment Ratio (with $\mathrm{P} / \mathrm{C}$ period)

$\operatorname{SIR}=\frac{(240,800+94,920)-(156,520+108,480)}{(104,775+7,938-1,813)-(98,108+7,620-1,715)}$

SIR $=\frac{70,720}{6,887}=10.3$ 


\section{Class Exercise A1}

Attic Insulation

Materials required: Annual Supplement to Handbook 135

Four-function calculator

Note: $\quad$ These problems are intended for manual solution.

Use the worksheet on the next page to determine the level of insulation with the lowest life-cycle cost, which is to be installed in the attic of a house located in Northern California. The existing insulation level is $\mathbf{R}-\mathbf{1 1}$.

$\begin{array}{lll}\text { Location: } & \text { West (Region 4) } & \\ \text { Base date: } & \text { June 2001 } \\ \text { Service date: } & \text { June } 2001 & \\ \text { Discount rate: } & \mathbf{3 . 3 \%} & \\ \text { Expected life: } & \mathbf{2 5} \text { years } & \\ \text { Replacements: } & \text { none } & \\ \text { Residual value: } & \text { none } & \\ \text { Electricity price: } & \mathbf{0 . 0 8 / k W h} & \\ \text { Rate type: } & \text { Residential } & \\ & & \text { Installed } \\ \text { Insulation } & \text { Annual energy consumption } & \text { Cost (\$) } \\ \text { Level } & \underline{\mathbf{k W h}} & \mathbf{0} \\ \text { R-11 } & \mathbf{9 6 0 2} & \mathbf{4 5 0} \\ \text { R-19 } & \mathbf{7 0 5 5} & \mathbf{6 5 0} \\ \text { R-30 } & \mathbf{6 8 0 4} & \mathbf{8 0 0} \\ \text { R-38 } & \mathbf{6 7 0 3} & \end{array}$




\section{Worksheet for Class Exercise A1}

(1)

(2)

(3)

(4) $=$

(3)X\$.08/kWh

(5)

(6) $=$

(4) $\times(5)$

(7) $=$

(2) $+(6)$

(8) $=$

$\mathrm{LCC}_{\mathrm{R}-\mathrm{0}}-\mathrm{LCC}_{\mathrm{R}-\mathrm{N}}$

Energy Cost

R-

Initial

value

Cost

(\$) $\quad \mathrm{kWh}$

$\underline{\mathrm{UPV}^{*}}$

Total

LCC

(\$)

Life

(\$)

Net Savings

R-11

0

9602

R-19

450

7055

R-30

650

6804

R-38

800

6703 


\section{Class Exercise A2}

Selection of Heating System

Select the residential heating system with the lower life-cycle cost and calculate its Net Savings and Savings-to-Investment Ratio. Use the worksheet on the next page.

Annual space heating load:

Fuel oil price:

Natural gas price:

Rate type:

Location:

Discount rate:

Base date/service date:

Study Period:

Initial cost:

Annual maintenance cost

Annual efficiency (average)

Expected life (years)

Residual value
50 MBtu

\$1.12/gallon (\$8.00/MBtu)

$\mathbf{\$ 0 . 8 0 / \text { therm (\$8.00/MBtu) }}$

Residential

Midwest (Region 2)

$3.3 \%$

June 2001

15 years

Oil Furnace

$\$ 4,500$

$\$ 100$

$82 \%$

15

$\$ 500$
Gas Furnace

$\$ 5,000$

$\$ 75$

$83 \%$

15

$\$ 1,000$ 


\section{Worksheet for Class Exercise A2}

LCC $=$ Initial Cost + PV energy + PV maintenance $-\mathrm{PV}$ residual value

Oil Furnace:

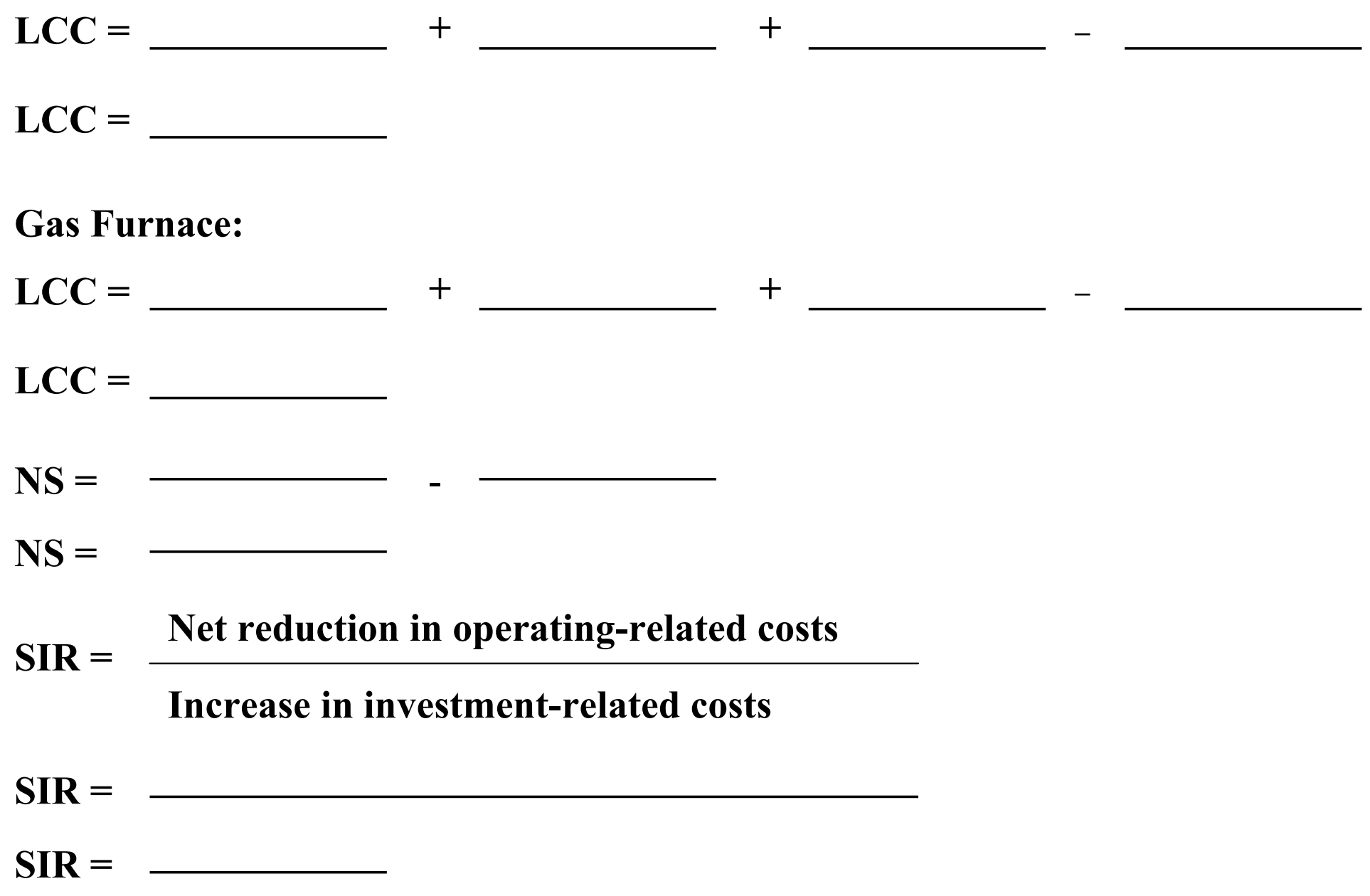




\section{Solution to Class Exercise A1}

Energy Cost

\begin{tabular}{|c|c|c|c|c|c|c|}
\hline $\begin{array}{l}\text { R- } \\
\text { value }\end{array}$ & $\begin{array}{c}\text { Initial Cost } \\
\text { (\$) }\end{array}$ & $\begin{array}{c}\text { Annual } \\
\text { kWh }\end{array}$ & $\begin{array}{c}\text { Annual } \\
(\$)\end{array}$ & $\begin{array}{l}\text { Life } \\
(\$)\end{array}$ & $\begin{array}{c}\text { Total LCC } \\
\text { (\$) }\end{array}$ & $\begin{array}{c}\text { Net Savi } \\
(\$)\end{array}$ \\
\hline 0 & 0 & 9602 & 768 & 12,150 & 12,150 & \\
\hline R-19 & 450 & 7055 & 564 & 8,922 & 9,372 & 2,778 \\
\hline$-30 *$ & 650 & 6804 & 544 & 8,606 & 9,256 & 2,894 \\
\hline R-38 & 800 & 6703 & 536 & 8,480 & 9,280 & 2,870 \\
\hline
\end{tabular}

$\mathrm{UPV} *=15.82$

*R-30 has the lowest Life-Cycle Cost and the highest Net Savings. 


\section{Solution to Class Exercise A2}

Lowest Life-Cycle Cost:

$\mathrm{LCC}=$ Initial Cost $+\mathrm{PV}$ energy $+\mathrm{PV}$ maintenance $-\mathrm{PV}$ residual value

Oil Furnace:

$\mathrm{LCC}=\$ 4,500+(50 / 0.82 \times \$ 8.00 \times 10.66)+(\$ 100 \times 11.68)-(\$ 500 \times 0.614)$

$\mathrm{LCC}=\$ 4,500+\$ 5,200+\$ 1,168-\$ 307$

$\mathrm{LCC}=\$ \mathbf{\$ 1 0 , 5 6 1}$

Gas Furnace:

$\mathrm{LCC}=\$ 5,000+(50 / 0.83 \times \$ 8.00 \times 10.16)+(\$ 75 \times 11.68)-(\$ 1,000 \times 0.614)$

$\mathrm{LCC}=\$ 5,000+\$ 4,896+\$ 876-\$ 614$

$\mathrm{LCC}=\$ \mathbf{1 0 , 1 5 8}$

Net Savings for Gas

Furnace:

$\mathrm{NS}=\$ 10,561-\$ 10,158$

$\mathrm{NS}=\$ \mathbf{4 0 3}$

SIR for Gas Furnace:

$\mathrm{SIR}=\frac{(\$ 5,200+\$ 1,168)-(\$ 4,896+\$ 876)}{(\$ 5,000-\$ 614)-(\$ 4,500-}$

$\mathrm{SIR}=\frac{\begin{array}{l}\$ 307) \\ \$ 596\end{array}}{\$ 193}$

$\mathrm{SIR}=3.09$ 


\section{Summary of the Life-Cycle Costing Method}

\section{Savings and investment costs}

The basic criterion for determining whether a design alternative that increases capital investment and lowers future operating costs is cost-effective is that the savings generated by the investment must be greater than the additional investment cost. The number of years over which the savings are accumulated and the weighting of future costs (or cost savings) relative to present costs are major considerations in life-cycle cost (LCC) analysis.

\section{Life-cycle cost}

The LCC concept requires that all costs and savings related to a design decision be evaluated over a common study period and be adjusted for the time value of money before they can be meaningfully compared. Choosing building systems on the basis of first cost alone can increase the long-run owning and operating costs of a building. For example, the purchase of a low-efficiency heating system, while initially less expensive than a more efficient system, will incur higher energy costs when in use. The difference may be significant since for many building systems only a small part of the life-cycle cost is attributable to the initial purchase price. The greater part is usually attributable to ongoing operating, maintenance, repair, and energy costs.

The principles of present-value analysis, which are the basis for the life-cycle cost method, apply to investments in federal, state, and local governments whether they are funded by the government agency from tax appropriations or financed through private-sector energy or utility services companies.

To supplement LCC analysis, there are additional measures of economic effectiveness, such as Net Savings (NS), Savings-to-Investment Ratio (SIR), Adjusted Internal Rate of Return (AIRR) and Discounted Payback Period (DPB) period. If computed correctly, all of these measures are consistent with the LCC method.

Particular care must be given to the use of the DPB as a criterion for accepting or rejecting projects. The DPB is consistent with the LCC method only when nothing more is required than that payback occur before the end of the study period and if cumulative net savings after payback is achieved are positive. DPB is not consistent with the LCC method when an arbitrary payback period is specified as a cut-off point for project acceptance.

\section{Comparing alternatives}

From a decision standpoint, the LCC of a design alternative only has meaning when it is compared against the LCC of a base case. For example, Alternative B has a higher investment cost but lower operating-related costs than Base Case A, although both are expected to perform equally well with regard to their basic purpose. Since the sum of investment cost plus operating cost (including energy costs) for alternative B is less than that for A, alternative B is the more costeffective choice. Note that in an existing building, the base case alternative (i.e., the existing design) may not require any investment; it may be the "do nothing" alternative. In that case, the life-cycle cost of the base case is made up entirely of operating-related costs, which must be compared against the combined investment and operating costs of the alternatives considered. In other cases (e.g., a 
new building design) the base case may be the design with the lowest first cost or the minimum level of performance that satisfies building code requirements.

\section{Minimizing total owning and operating costs}

The graph in slide A-5 is typical of energy conservation investments. It compares the owning and operating costs associated with a wide range of energy efficiency levels for a building system (e.g., exterior wall insulation or air conditioner efficiency). Generally, as the level of energy efficiency increases, the initial cost increases at an increasing rate. Lower levels of efficiency can generally be achieved at low cost, but as the efficiency level is increased, structural, mechanical, or design modifications must be made to accommodate the added components. This quickly adds to the initial cost. For example, to increase the effective thermal resistance value of a wall, the wall thickness must be increased or a more costly type of insulation must be used; or, in the case of air conditioners, significantly larger heat exchangers or more costly compressors are necessary to increase energy efficiency. For some systems, such as fossil-fired furnaces, there are practical limits to the extent to which efficiency can be increased, causing the investment cost curve to bend sharply upwards.

The operating cost curve in the graph shows that as the energy efficiency of the system is increased, energy consumption is decreased, but at a decreasing rate. In fact, energy consumption is generally inversely proportional to energy efficiency so that additional units of improvement generate less savings than the ones before. For example, increasing the thermal resistance value of attic insulation from R-30 to R-40 only saves about $18 \%$ as much energy as increasing the level from R-10 to R-20.

The total cost curve is the vertical summation of the investment cost and operating cost associated with any level of energy efficiency. The lowest point on the total cost curve, $\mathbf{Q}^{*}$, determines the level of energy efficiency that minimizes life-cycle costs. It is important to recognize that there are a number of factors that contribute to this result. For example, longer study periods, more severe climates, lower conservation costs (say through technology improvements), and higher energy prices all tend to result in a higher level of energy efficiency becoming cost-effective.

\section{Maximizing net savings}

The graph in slide A-6 shows that the most cost-effective level of energy conservation can also be determined by finding the level that maximizes net savings, the difference between total costs and total savings. The slide shows two curves, the investment cost curve, which is identical to that shown in the previous slide, and a savings curve. The savings curve is determined by taking the difference between the operating cost at the zero level of investment and the operating cost at any other level of investment on the graph.

Note that total savings are greater than total costs anywhere between the origin and the point where the two curves cross. Thus we might conclude that any level of investment between these two points is justified. But in fact the economically optimal level of energy efficiency is that level for which net savings is greatest, again $\mathrm{Q}^{*}$. This is the same point that was determined by finding the level with the lowest LCC. This is not surprising if you recognize that net savings at any point along the horizontal axis of the graph in slide A-5 is the difference between the LCC of the base case (measured at the zero investment level) and the LCC of the alternative at that point. Thus the energy efficiency level with the lowest LCC must have the highest net savings. By contrast, at the point 
where investment cost just equals savings (slide A-6), you are no better off than you were at the origin, since in both cases net savings is zero.

\section{Incremental savings versus incremental costs}

Graph A-7 provides an additional look at the relationship between the investment cost curve and the operating cost curve. Here incremental costs and incremental savings are plotted. Each additional unit of energy efficiency results in smaller and smaller increments in savings and greater and greater additions to cost. The shape of these curves is quite typical: conservation investment costs are increasing at an increasing rate and energy savings are decreasing at a decreasing rate. The point where these two curves cross determines the economically optimal level of energy efficiency, again $Q^{*}$, the point at which the last increment in cost increases savings by the same amount. This is the same point, $\mathrm{Q}^{*}$, found by minimizing LCC or maximizing net savings. At any point to the left of $Q^{*}$, incremental savings are higher than incremental costs, so that increasing the energy efficiency level will reduce life-cycle costs and increase net savings. At any point to the right of $\mathrm{Q}^{*}$, the intersection, incremental savings are less than incremental costs, so that reducing the energy efficiency level will reduce life-cycle costs and increase net savings.

\section{Economic efficiency}

It is essential to recognize that all three of these methods arrive at the same optimal level of energy efficiency. In general, if the LCC methodology is applied correctly, all three of these methods arrive at the same optimal level of energy efficiency. Economists refer to the level of investment where life-cycle cost is minimized, net savings is maximized, and incremental investment is equal to incremental savings as the "economically efficient" level of investment for a given project.

The above treatment of costs and savings assumes that the energy efficiency of building systems can be improved in a continuous fashion. In fact, commercially available systems are rarely available in a continuous range of efficiency ratings. However, the underlying concepts shown here are valid even when efficiency improvements come in "step" form. That is, the alternative with the lowest LCC will be the most cost-effective choice, given that it satisfies the other performance objectives of the system. In every case, finding the alternative with the lowest LCC will provide sufficient information to choose the economically efficient level of investment.

\section{Types of decisions}

There are five types of investment decisions related to energy conservation to which economic analysis can be usefully applied:

(1) An accept/reject project is a project that is optional from a building design standpoint and can be either implemented or not, depending on whether or not it is a good investment. A good example is the installation of standard storm windows over existing single-pane windows in a house. The comfort level of a house can be maintained at an acceptable level with or without storm windows, but with storm windows installed much less energy will be used. (If several options are available with different levels of energy performance, then this becomes a decision about the optimal efficiency level.) Optimal efficiency level refers to the problem of selecting the most cost-effective level of energy performance for a building system. For example, attic insulation can be installed over a wide range of thermal resistance levels, an air conditioner can have a wide range of seasonal efficiency ratings, and a solar heating system can have a wide range of collector areas. 
(2) Optimal system selection refers to the problem of selecting the most cost-effective system type for a particular application. System selection can directly impact the energy performance of a building. Examples include the choice of the heating and cooling system types for a building (e.g., electric heat pump or gas furnace with electric air conditioning), wall design (e.g., masonry or wood frame), or even insulation type (e.g., rigid foam or mineral wool).

(3) Optimal combination of interdependent projects refers to the problem of selecting two or more building systems at the same time, recognizing that the implementation of one system will have significant effects on the energy savings potential of the other, and vice-versa. For example, installing a high-efficiency furnace will reduce the energy savings potential of storm windows, while installing storm windows will reduce the energy savings potential of installing a high-efficiency furnace.

(4) Prioritization of independent projects is required when a number of cost-effective energy conservation investments have been identified but not enough funding is available to implement all of these projects. Economic analysis allows the ranking of these projects in decreasing order of cost-effectiveness as a guideline to allocating available funding.

\section{Basic steps in LCC analysis}

The basic steps in an LCC analysis are to

- $\quad$ identify the alternatives under consideration,

- $\quad$ specify the data requirements and establish assumptions,

- $\quad$ estimate the costs in dollars,

- $\quad$ adjust costs for time value of money,

- $\quad$ compute total LCC for each alternative, and

- $\quad$ choose the alternative with the lowest total life-cycle cost.

Depending on the circumstances, you may also want to calculate supplementary measures of economic performance, perform an uncertainty assessment, and add a narrative describing noneconomic issues. All of these steps will be covered during the workshop.

\section{Typical project costs Relevant effects}

To make a decision about economic efficiency, it is important to measure the economic consequences of alternatives. Data requirements for making an economic decision are not the same as those for keeping an accounting system. For an LCC analysis, you need, in general, evaluate only costs that change from one alternative to another. Costs that remain the same do not decrease or increase the life-cycle costs of an alternative relative to the base case and thus need not be included.

Because collecting cost data can be expensive, you want to focus on collecting those data which are likely to have a significant effect on the life-cycle costs of an alternative. You do not want to spend your limited resources on collecting data that have little impact. 
Do not include "sunk" costs in your analysis. Sunk costs are those costs that have already been incurred and cannot be avoided by future decisions. Only amounts that can be changed by the decision need to be included in the analysis.

Non-tangible costs are costs or benefits that cannot easily be expressed in dollar amounts. Even though they cannot be explicitly included in an LCC analysis, their effects should be described in a narrative so that they will not be overlooked when making a decision.

Types of costs

Life-cycle costs typically include investment-related costs and operational costs. Acquisition costs, including costs for planning, design, and construction, are investment-related, as are residual values such as resale value, salvage value, or disposal costs. Under the FEMP rule, capital replacement costs are also defined as investment-related. Energy costs, maintenance costs, and repair costs are considered operational costs, that is, non-investment-related costs. This definition is useful when computing economic measures that evaluate long-run savings in operational costs in relation to total capital investment costs.

Some of the costs included in an LCC analysis are annually recurring, such as energy, and routine maintenance and repair costs. Non-annually recurring costs are those that may occur only one time during the life-cycle, such as acquisition costs and residual values, or several times, such as replacement costs. This definition is needed for choosing the appropriate discount factors used to convert future costs to present values.

In a third classification, acquisition costs are designated as initial costs and all other costs as future costs, a useful classification both for selecting discount factors and for relating initial investment costs to the operating costs of a project.

All costs included in the analysis are expressed in base-year dollars. These base-year amounts will be multiplied by discount factors that incorporate the discount rate and any applicable escalation rate.

\section{Energy and water costs}

Special criteria apply to energy costs in analyses of conservation measures considered for federal buildings:

Current prices: It is essential to get current energy prices from local suppliers. It is better not to use regional or national average energy or water cost data, since they do not reflect local supply and demand conditions. Prices should take into account, where applicable, rate type, rate structure, summer and winter differentials, block rates, and demand charges to reflect an estimate as close as possible to today's actual price.

Energy price projections: Energy prices are assumed to increase or decrease at a rate different from general price inflation. To avoid inconsistencies in LCC analyses throughout the government, it is required under the FEMP rule (10 CFR 436A) to adjust today's energy price estimates by the energy price projections published annually by DOE. These energy price projections are embedded in the discount factors updated annually and published on April 1 of each year in Energy Prices and Discount Factors for Life-Cycle Cost Analysis 20xx, Annual Supplement to NBS Handbook 135 and 
NBS Special Publication 709. These projections are also included in the NIST BLCC computer programs.

Water costs: In 1995 water conservation was added to energy conservation as a designated goal for the Federal Energy Management Program. No special water usage/disposal escalation rates are projected by DOE.

\section{Setting the study period}

The study period is the time over which the effects of a decision are of interest to the decision-maker. There is no one correct study period, but it must be sufficiently long to enable a correct assessment of long-run economic performance. Often the life of the system under analysis is used as the study period. However, the Federal Government limits the study period for energy and water conservation projects to a maximum of 25 years from the service date. Apart from the 25 -year maximum limit, there are other factors that determine the length of the study period:

(1) Compare all alternatives over the same study period. Present-value cash flows calculated for one time period would not be comparable with those calculated for a longer or shorter period.

(2) Calculate all measures of economic evaluation (LCC, NS, SIR, AIRR) using the same study period, otherwise they would not be consistent with each other.

(3) Consider the time horizon of the investor. The study period may be shorter or longer depending on whether the investor is, for example, the builder or the occupant of a building.

(4) Adjust for different expected lives of buildings or systems. In order to fit different expected lives into the same study period, equalize the differing time periods by using replacement values and residual values, such as a resale value, salvage value, or disposal costs.

\section{Discounting future costs to present value}

Before we can compare or sum costs occurring at different points over the study period, they must be converted to a common point in time to reflect the time value of money. This means that future costs (or savings) have to be discounted to present value so that they can be directly compared with initial investment costs.

\section{Cash-flow conventions}

There are several cash-flow conventions that may be used when discounting costs occurring over the study period to present value. One-time costs are usually discounted from the actual time of occurrence. Annually recurring costs are discounted from the end of the year (FEMP) or the middle of the year (DoD). Costs occurring at the beginning of the study period do not need to be discounted since they are already in present value.

\section{Discount rate}

The discount rate used to adjust future costs to present value is the rate of interest that makes the investor indifferent between cash amounts received at different points in time. The discount rate adjusts for inflation and the real earning power of money. This rate is often referred to as the 
minimum acceptable rate of return (MARR). It is important to recognize that every investor has his or her own time preference for money, and thus his or her own discount rate.

\section{Discount factors}

Pre-calculated discount factors can be used to calculate present values by multiplying the base-year dollar amounts by the appropriate discount factor. NIST publication Discount Factor Tables for LifeCycle Cost Analyses (NISTIR 89-4203) contains pre-calculated discount factors that incorporate FEMP and OMB discount rates and DOE energy price escalation rates. These discount factors are also embedded in the NIST BLCC programs.

\section{Common discount factor applications}

When performing an LCC analysis, three types of future cash flows are most commonly encountered, each requiring a different type of present-value factor:

(1) The one-time cash flow is multiplied by the Single Present Value (SPV) factor to find its present value. An example of a one-time cash flow is a replacement cost or a residual value at the end of the study period.

(2) The uniform annual amount is multiplied by the Uniform Present Value (UPV) factor to find the present value. An example of a uniform annual amount is an annual operating and maintenance cost that remains the same from year to year.

(3) The changing annual amount varies from year to year at some known rate, which can be either constant or variable from year to year. The base-year amount $\left(\mathrm{A}_{0}\right)$ is multiplied by the Modified Uniform Present Value (UPV*) factor to find the present value. An example of an amount that changes at a variable rate each year is the annual energy cost of a building when the physical amount of energy consumed is expected to be reasonably constant but energy prices are expected to change from year to year. An amount changing at a constant rate may be an operating cost that increases annually due to expected higher maintenance costs.

\section{$\mathrm{UPV}^{*}$ factors for energy costs}

For LCC analyses related to energy conservation in federal facilities, NIST publishes UPV* factors specifically for use with future energy costs. The NIST UPV* factors explicitly incorporate the FEMP discount rate and DOE projections of energy price increases over the next 30 years. They are published in NISTIR 85-3273, Energy Price Indices and Discount Factors for Life-Cycle Cost Analysis 20xx, tables B-1a through B-5a. Because the FEMP discount rate and the DOE projections of energy price escalation rates change from year to year, this publication is updated by NIST each year on April 1. The UPV* factors in this publication are differentiated by fuel type, rate type (residential, commercial, industrial), and by region (Northeast, Midwest, South, and West). The

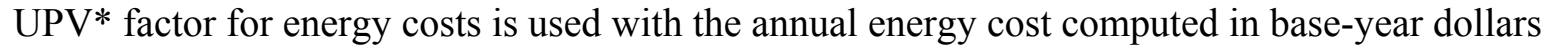

\section{How to handle inflation in LCC analysis \\ Definitions}

An economic evaluation of capital investments over time needs to consider both the earning power of money, as reflected by the discount rate, and the changing purchasing power of the 
dollar. The following five terms will be used in the discussion of how to handle inflation in lifecycle cost analysis:

- Price inflation: A rise in the general price level, tantamount to a decline in the general purchasing power of the dollar.

- $\quad$ Price escalation: Increase in the price of a particular commodity, such as energy.

- Differential price escalation: The difference between the rate of general inflation and the rate of escalation in the price of a particular commodity. For example, if the price of a particular commodity increases at exactly the same rate as general inflation, the differential price escalation rate is 0 percent. Energy prices are a type of cost that has deviated significantly from general inflation since the early 1970s. For this reason, the FEMP LCC methodology for evaluating energy conservation investments requires that projected increases in energy prices be explicitly included in the economic analysis, while other categories of costs are generally assumed to increase at the rate of general inflation.

Current dollars and constant dollars: Current dollars include the rate of general price inflation, constant dollars exclude the rate of general price inflation.

- Nominal discount rates and real discount rates: Nominal discount rates include the rate of general price inflation, real discount rates exclude the rate of general price inflation.

\section{Treatment of inflation}

There are two basic approaches for dealing with inflation in an economic analysis.

(1) Use current dollars and a nominal discount rate and price escalation rates. The rate of inflation is included in the future dollar amounts, and in the discount and price escalation rates. This is the approach that is generally used when tax considerations are included in the economic analysis, or when current-dollar cash flows need to be compared with current-dollar savings, as is the case for ESPC projects.

(2) Use constant dollars and a real discount rate and price escalation rates. Future dollar amounts exclude, and the discount and escalation rates exclude inflation. In this case only differential price escalation rates are included in the analysis, exclusive of general inflation. Constant-dollar analyses are generally used in agency-funded government studies.

Both constant- and current-dollar analyses, if conducted properly, will yield exactly the same present-value result, and thus support the same conclusion. However, it is generally easier to conduct an economic analysis in constant dollars because the underlying rate of inflation from year to year over the study period does not need to be estimated.

It is important to differentiate between a present-value analysis of a capital investment and a budget analysis, where funds must be appropriated for year-to-year disbursement. The purpose of a present-value analysis is to determine whether the overall savings appear to justify the required investment at the time that the investment decision is being made. A budget analysis must include 
general inflation to assure that sufficient funding will be appropriated in future years to cover actual expenses.

\section{Relationship between real and nominal rates:}

$$
\begin{array}{lll}
\mathrm{d} & = & (1+\mathrm{D}) /(1+\mathrm{I})-1 \\
\mathrm{D} & = & (1+\mathrm{d})(1+\mathrm{I})-1 \\
\mathrm{e} & = & (1+\mathrm{E}) /(1+\mathrm{I})-1 \\
\mathrm{E} & = & (1+\mathrm{e})(1+\mathrm{I})-1
\end{array}
$$

where $\mathrm{d}=$ real discount rate, excluding inflation

$\mathrm{D}=$ nominal discount rate, including inflation

e $=$ real rate of escalation, excluding inflation

$\mathrm{E}=$ nominal rate of escalation, including inflation

$\mathrm{I}=$ rate of inflation

\section{Supplementary measures of economic performance}

Supplementary measures of economic performance can be used to determine the comparative costeffectiveness of capital investment. Several widely used measures are presented in this workshop. These are Net Savings, Savings-to-Investment Ratio, Adjusted Internal Rate of Return, and Payback Period. Except for the Payback Period, these measures are consistent with and build upon the Life-Cycle Cost methodology. All of these supplementary measures are comparative rather than absolute measures of performance because they are only meaningful in relation to an alternative course of action, i.e., the base case.

\section{Net Savings (NS)}

NS is a measure of long-run profitability of an alternative relative to a base case. The NS can be calculated as an extension of the LCC method to show the difference between the LCC of a base case and the LCC of an alternative. It can also be calculated directly from differences in the individual cash flows between a base case and an alternative.

The NS can be used like the LCC measure to determine a project's cost-effectiveness. For a project alternative to be cost-effective with respect to the base case, it must have an NS of greater than zero. Even with a zero Net Savings, the minimum required rate of return (MARR) has been achieved because the required rate of return is built into the net savings computation through the discount rate. NS is not useful for ranking projects.

\section{Savings-to-Investment Ratio (SIR)}

The SIR is a dimensionless measure of performance that expresses the ratio of savings to costs. The numerator of the ratio contains the operation-related savings; the denominator contains the increase in investment-related costs. An SIR > 1.0 means that an alternative is cost-effective relative to a base case. For selecting the optimal energy efficiency level or the optimal system or design, the SIR method is reliable only if based on incremental SIRs.

The SIR is recommended for setting priority among projects when the budget is insufficient to fund all cost-effective projects. The projects are ranked in descending order of their SIRs. 
Adjusted Internal Rate of Return (AIRR)

The AIRR is calculated as a percentage yield. The yield rate is compared with the investor's MARR. The AIRR has to be higher than the MARR for an investment to be considered cost effective. (The AIRR is a modified version of the Internal Rate of Return (IRR); it uses the discount rate rather than the calculated rate of return as the reinvestment rate for saved cash flows.) The AIRR is used in the same way as the SIR.

\section{Discounted Payback (DPB)}

The DPB measures how long it takes to recover initial investment costs. It is calculated as the number of years elapsed between the initial investment and the time at which cumulative savings, net of accrued costs, are just sufficient to offset investment costs. The DPB takes the time value of money into account by using discounted cash flows. If the discount rate is assumed to be zero, the method is called Simple Payback (SPB), a measure of evaluation less accurate than the DPB.

Both the DPB and the SPB ignore all costs and savings that occur after payback has been reached. They should be used only as a rough screening measure for accept/reject decisions.

\section{Uncertainty assessment in LCC analysis}

Decisions about energy conservation investments in buildings typically involve a great deal of uncertainty about their costs and potential savings. Performing an LCC analysis greatly increases the likelihood of choosing an alternative that saves money in the long run. Yet, there may still be some uncertainty associated with the LCC results; LCC analyses are usually performed early in the design process when only estimates of costs and savings are available rather than certain dollar amounts. Uncertainty in input values creates risk that a decision will have a less favorable outcome than what is expected.

Even though you may be uncertain about some of the input values, especially those occurring in the future, it is still better to include them in an economic evaluation than to base your evaluation on first costs only. Ignoring uncertain long-run costs implies the assumption that they are zero, a poor assumption to make.

There are techniques that allow you to estimate the cost of choosing the "wrong" alternative. Sensitivity analysis and breakeven analysis are two approaches that are so simple to perform that they should be part of every LCC analysis. These and a number of other approaches to risk and uncertainty assessment are described in detail in Techniques for Treating Uncertainty and Risk in the Economic Evaluation of Building Investments by Harold E. Marshall, NIST Special Publication 757, September 1988.

\section{Sensitivity analysis}

Sensitivity Analysis measures the impact on the analysis results of changing one or more key input values about which there is uncertainty. Sensitivity analysis can be performed with respect to any measure of worth (LCC, NS, SIR, AIRR, PB). The sensitivity of these measures can be compared among alternatives. 
Identifying critical inputs: It is important to know which of the uncertain input parameters have the greatest effect on LCC results. To identify the critical inputs, simply increase the value of each of them in turn by a certain percentage and, holding all others constant, recalculate the economic measure to be tested. The higher the percentage change in outcome for a given change in input value, the greater the effect.

Estimating the range of results: To arrive at an estimate of the upper and lower bounds of an economic measure, it can be recalculated using the lowest and highest likely estimates of its input variables, corresponding to the most optimistic or pessimistic scenarios.

"What if" scenarios: Identifying critical input values and determining the range of economic measures answers a number of "what if" questions. Sensitivity analysis is a good technique for taking a closer look at the most plausible "what if" scenarios, in order to be prepared to answer these types of questions when they arise during the decision-making process.

\section{Breakeven analysis}

Decision makers sometimes want to know the maximum cost of an input that will allow the project to still break even, or, conversely, what minimum benefit a project can produce and still cover the cost of the investment.

To perform breakeven analysis, benefits and costs are set equal; all variables are specified, except the breakeven variable; and the breakeven variable is solved for algebraically.

\section{Advantages and disadvantages of sensitivity and breakeven analyses}

Results of sensitivity analysis and breakeven analysis can be presented in text, tables, or graphs. They are easy to perform and easy to understand and require no additional methods of computation beyond those needed for LCC analysis. The breakeven value can serve as a benchmark value to be compared against its predicted performance. The disadvantages of sensitivity analysis and breakeven analysis are that they do not give a probabilistic measure of the risk of choosing an uneconomic project and do not include an explicit measure of risk attitude.

\section{Summary of FEMP LCC criteria}

The following criteria, consistent with the FEMP rules outlined in 10 CFR 436A, specifically apply to the economic evaluation of energy and water conservation and renewable energy projects in federal buildings:

\section{Constant-dollar analysis}

In general, use constant dollar analysis and real discount and escalation rates. The DOE/FEMP discount rate and energy price escalation rates are real rates, that is, they exclude the rate of general price inflation. If, as for example, in the case of alternative financing projects, the analysis is performed in current dollars, the inflation rate has to be added to the discount rate and price escalation rates.

The DOE discount rate and corresponding discount factors are updated annually on April 1 and published in NISTIR 85-3273, Energy Price Indices and Discount Factors for Life-Cycle Cost Analysis, the Annual Supplement to NIST Handbook 135, and in the NIST LCC computer programs, BLCC4 and BLCC5. 


\section{Discounting convention}

Cash flows are discounted from the end of the year. (In analyses of military construction projects, cash flows are discounted from the middle of the year.)

\section{Present values}

For reasons of consistency, the FEMP rule prescribes the use of present-value analysis for evaluating energy- and water-related projects. All future dollar amounts should be discounted to the base date of the project. Note that "present-value" amounts are not the same as constant dollar amounts as of the base date, since the latter do not reflect the time value of money.

\section{Energy prices}

The FEMP LCC method uses local energy and water prices at the building site in calculating the annual dollar value of the energy or water consumed by a building or building system. Local energy and water prices should reflect the type of rate charged (residential, commercial, or industrial), differences between summer and winter rates, the impact of block rates on marginal energy and water costs, and demand charges. The analyst should not artificially adjust energy or water prices to reflect environmental externalities.

If fuel is purchased for on-site electricity generation, the costs of the fuel at the point of generation, plus the costs incurred in generating and distributing the electricity, should be used in the analysis.

\section{Quantity of energy and water usage}

Since the FEMP LCC method uses local energy and water prices at the building site, energy and water quantities should be stated in units consistent with unit prices at the point of metering. Equivalent quantities of energy or water at some earlier point in the supply chain (e.g., oil or coal prices before conversion to electricity) should not be used.

\section{DOE energy price escalation rates}

Energy prices are assumed to change at rates different from the rate of general price inflation. DOE annually projects real (differential) energy price escalation rates for the next three years, by Census region, rate type, and fuel type. These real energy price escalation rates and the real DOE discount rate are used to calculate the modified present value factors (UPV* factors) for use in FEMP LCC analyses. The UPV* factors are updated and published annually as a set of tables in NISTIR 853273, the Annual Supplement to Handbook 135. At present there are no equivalent DOE projections of escalation rates for water costs.

The real price escalation rates for energy costs are incorporated into LCC evaluations in the following ways:

(1) by multiplying the appropriate UPV* factor by the base-year annual energy cost (or savings) to calculate a present value; or

(2) by using the most recent version of the NIST BLCC computer programs, which read the DOE-projected differential escalation rates from a file on the diskette and automatically compute the present value of energy costs 
Items other than energy and water costs in FEMP studies are generally assumed to have a zero real escalation rate unless there is documentable evidence to the contrary. This is equivalent to saying that the prices of non-energy items are assumed to change at the same rate as general price inflation.

\section{Study period}

The maximum study period for federal energy conservation projects is 25 years from the date of occupancy of a building or the date of operation of a system. Any lead time for planning, design, or construction may be added to the 25 -year maximum study period.

The study period should be the same for all alternatives under consideration and the lesser of 25 years, or the estimated use of the building or life of the system. Replacement costs and residual values, such as a salvage value, a disposal cost, or a resale value, are used to equalize the study period for the various alternatives.

For evaluating energy use and related investments in a leased federal building, the study period is the lesser of 25 years or the effective remaining term of the lease, including renewal options likely to be exercised.

\section{Uncertainty assessment}

If uncertainty analysis casts substantial doubt on the results of LCC analysis, federal agencies are advised to obtain more reliable input data or eliminate the project. Federal agencies are directed to use the DOE discount rate as published, without testing for sensitivity.

\section{No evaluation required}

The FEMP rule states that

(1) A project is presumed cost-effective if it saves energy and if the costs of implementing the energy conservation measure are insignificant, and

(2) a project is presumed not cost-effective if the building is

(a) occupied under a one-year lease without renewal option or with a renewal option that is not likely to be exercised;

(b) occupied under a lease that includes the cost of utilities in the rent, with no pass-through to the government of energy savings; or

(c) scheduled for demolition or retirement within one year. 


\section{Module B}

\section{NIST LCC Software: Overview and BLCC5}

Objectives: Upon completion of this module, you will be able to

- use BLCC5 to evaluate energy and water conservation projects.

- describe the features of other NIST LCC computer programs. 


\section{BLCC 5.0-01 \\ Building Life-Cycle Cost Program (windowed version of BLCC4)}

for Energy and Water Conservation and Renewable Energy Projects 


\section{Overview - BLCC5}

- Economic analysis of capital investments that reduce future costs

- Focus on energy and water conservation in buildings

- Current modules

- agency-funded projects (direct appropriations)

- financed projects (ESPC/UC)

- Future modules

- MILCON

- private sector

- Downloadable from DOE web site 


\section{Data Requirements}

- Project Information

- name, location, analyst, comment, discounting convention, constant or current dollars, discount rate, base date, service date, and length of study period

- Capital Investment Costs

- investment costs

- cost-phasing

- escalation rates

- replacement costs and timing

- residual values 


\section{Data Requirements (cont.)}

- Operating-Related Costs

- annually recurring $\mathrm{OM \& R}$

- non-annually recurring OM\&R

- energy consumption and cost data

- water consumption and cost data

- escalation rates

- Contract Costs

- annually recurring (annual contract payment, debt service, performance period expense)

- non-annually recurring (implementation cost, financing procurement cost) 


\section{Creating a BLCC5 Input File}

- Input general information for the project.

- Input data for each alternative.

- Use tree as a guideline and checklist.

- Go to Help - Creating and Editing Data Files - for definitions of all input variables .

- Print reports

- LCC computations are made each time a report is opened.

- Save project file using user-supplied filename. 


\section{BLCC5 Tree}

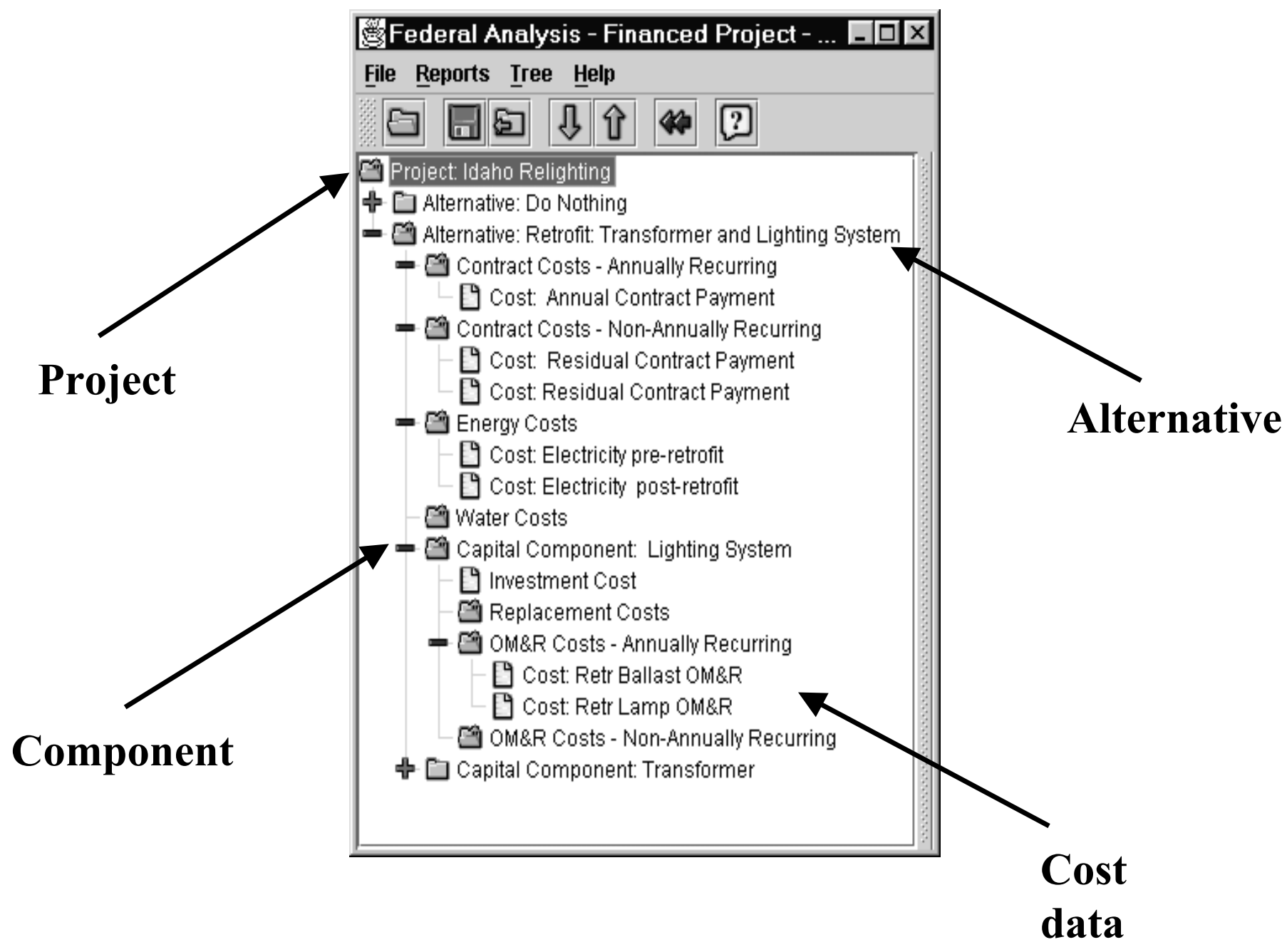




\section{Project Data}

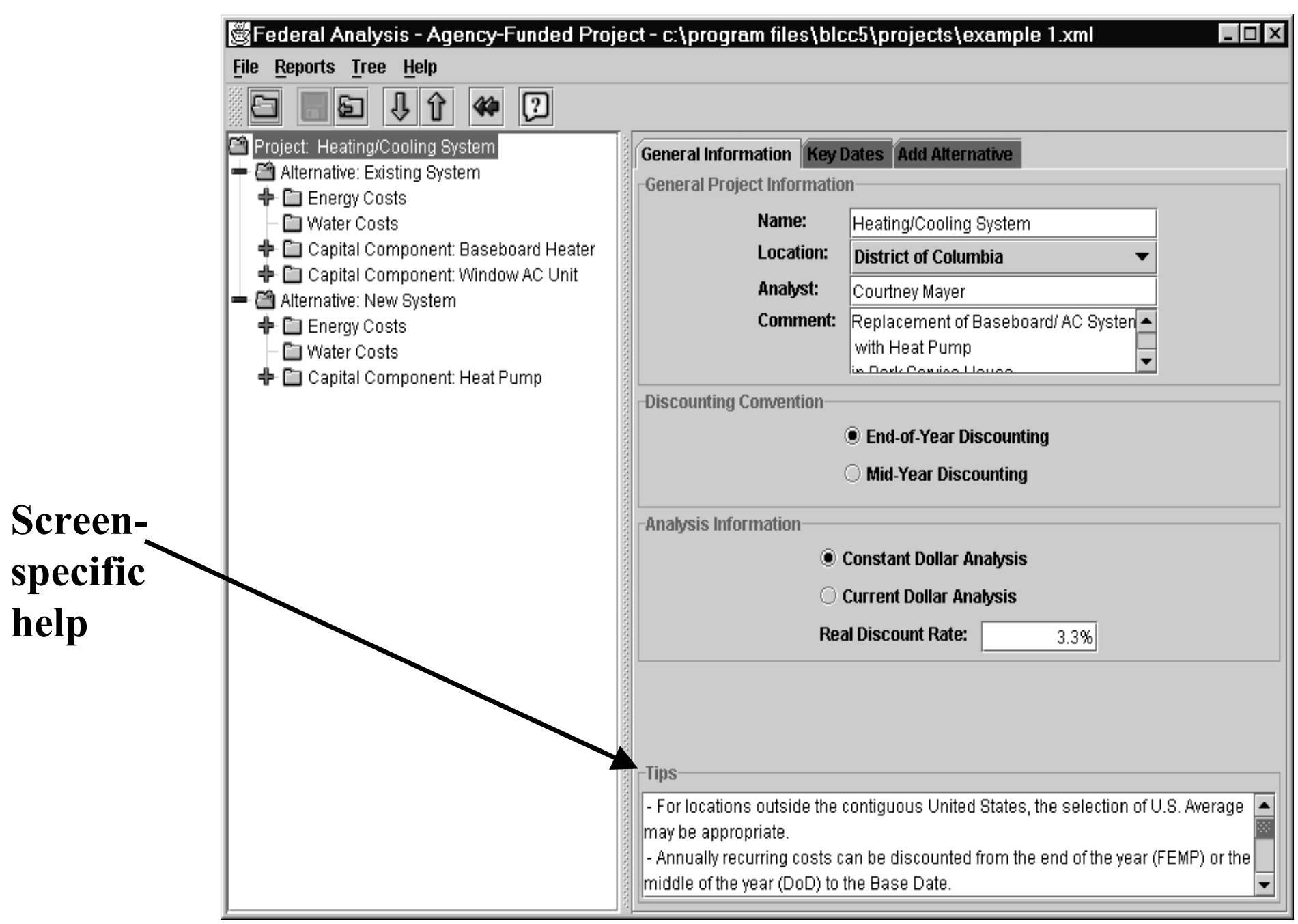




\section{Add/Copy Feature}

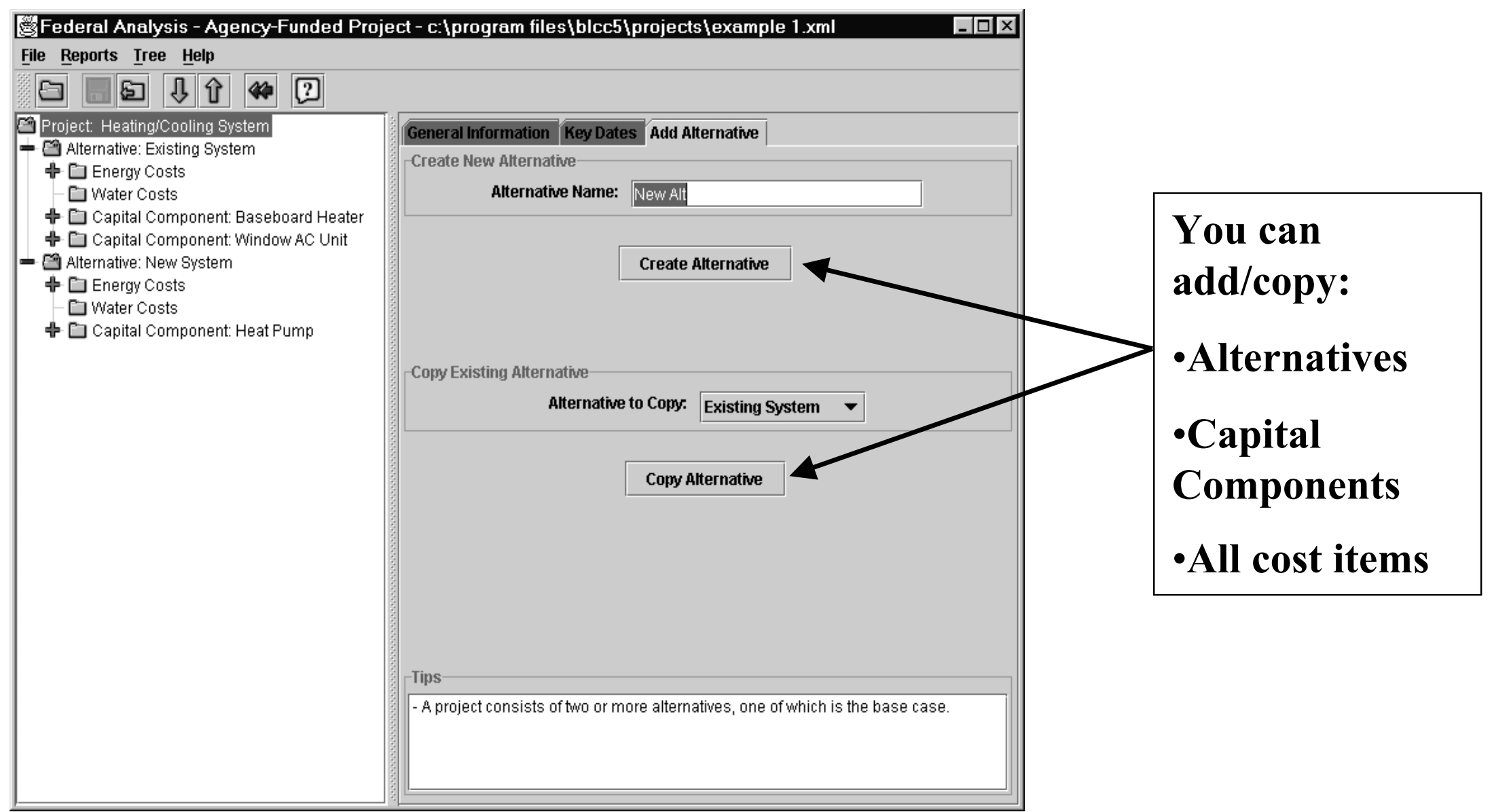




\section{Delete Feature}

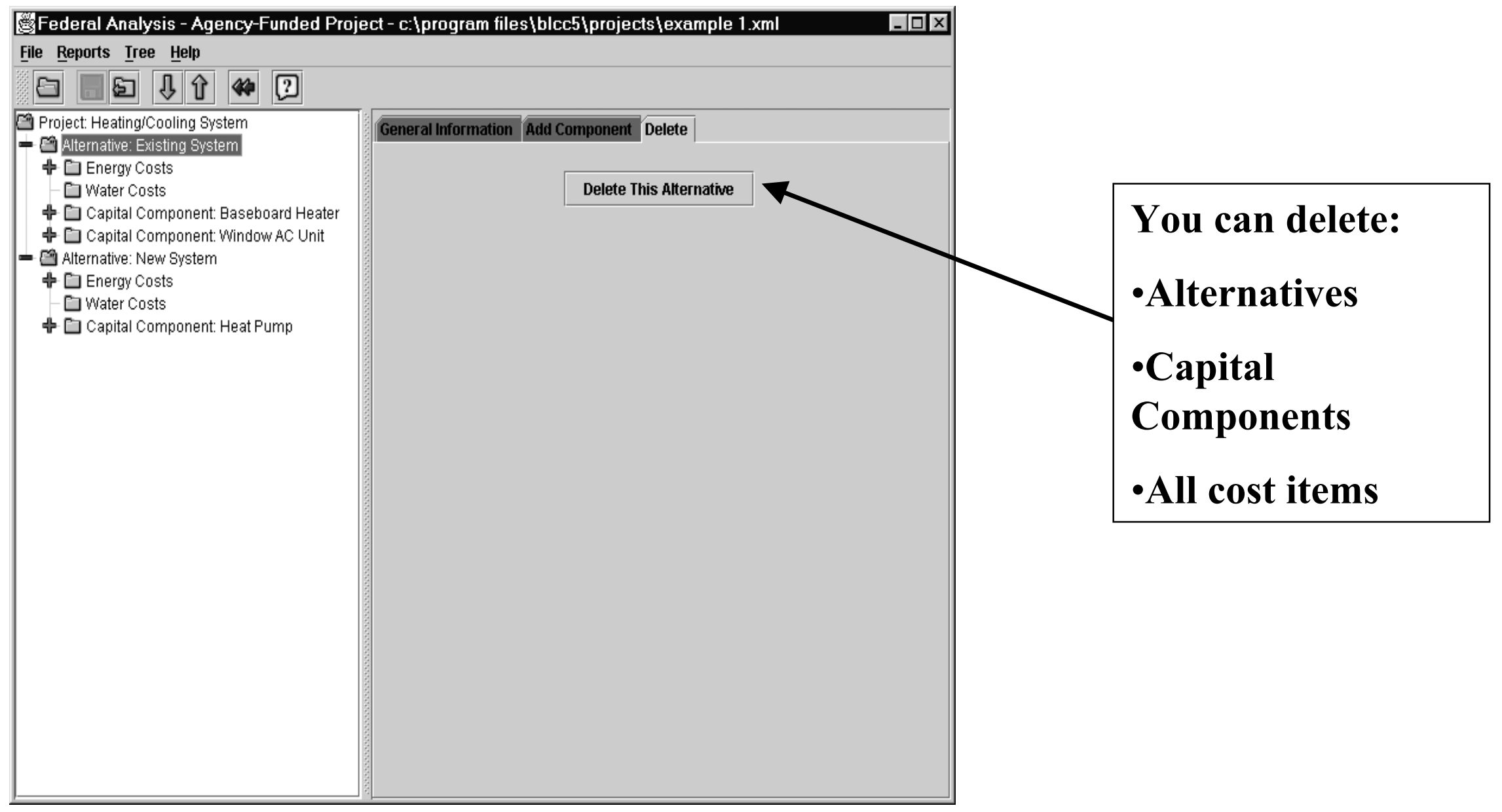




\section{Energy Usage}






\section{Energy Costs}

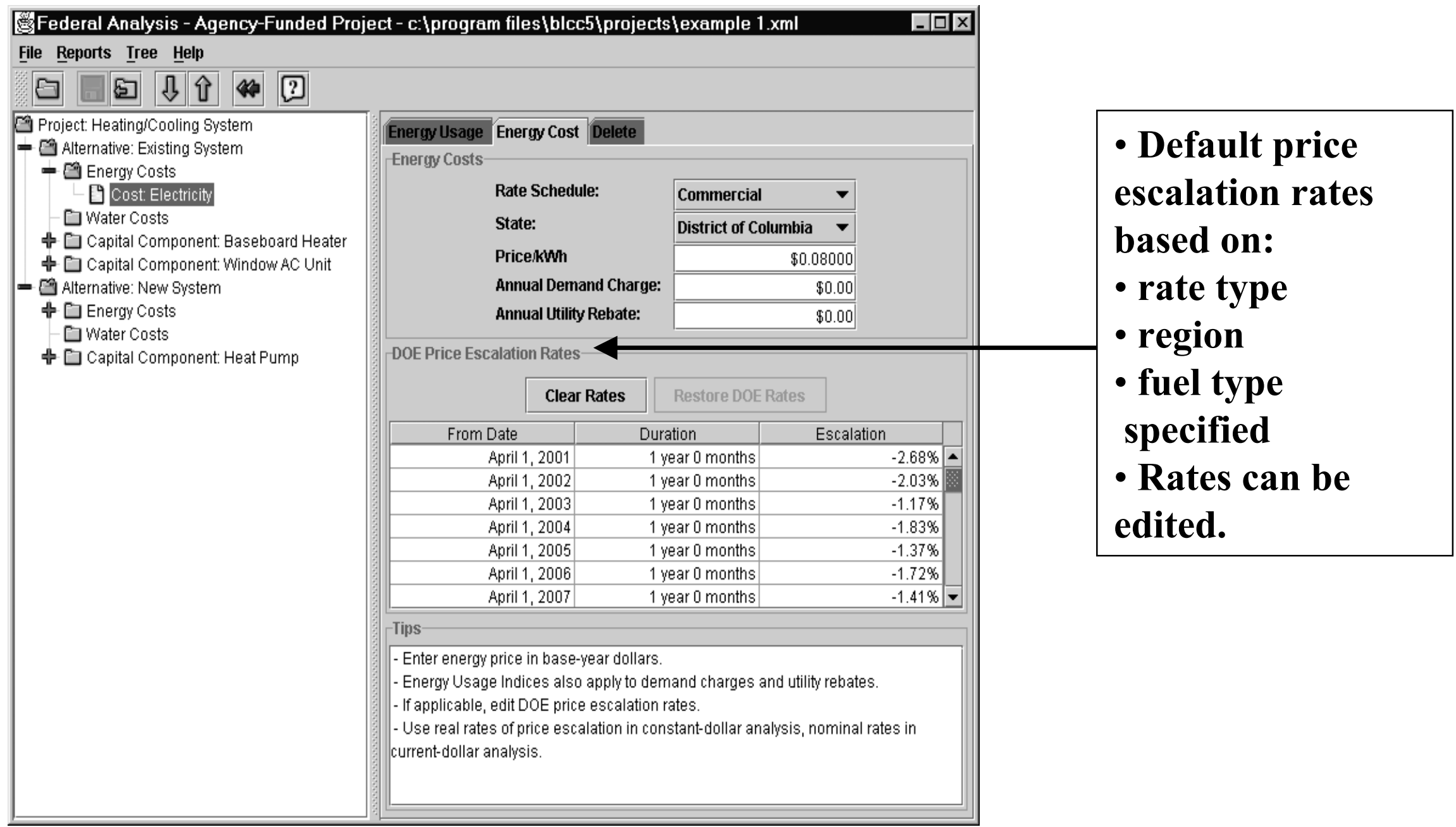




\section{Water Costs}

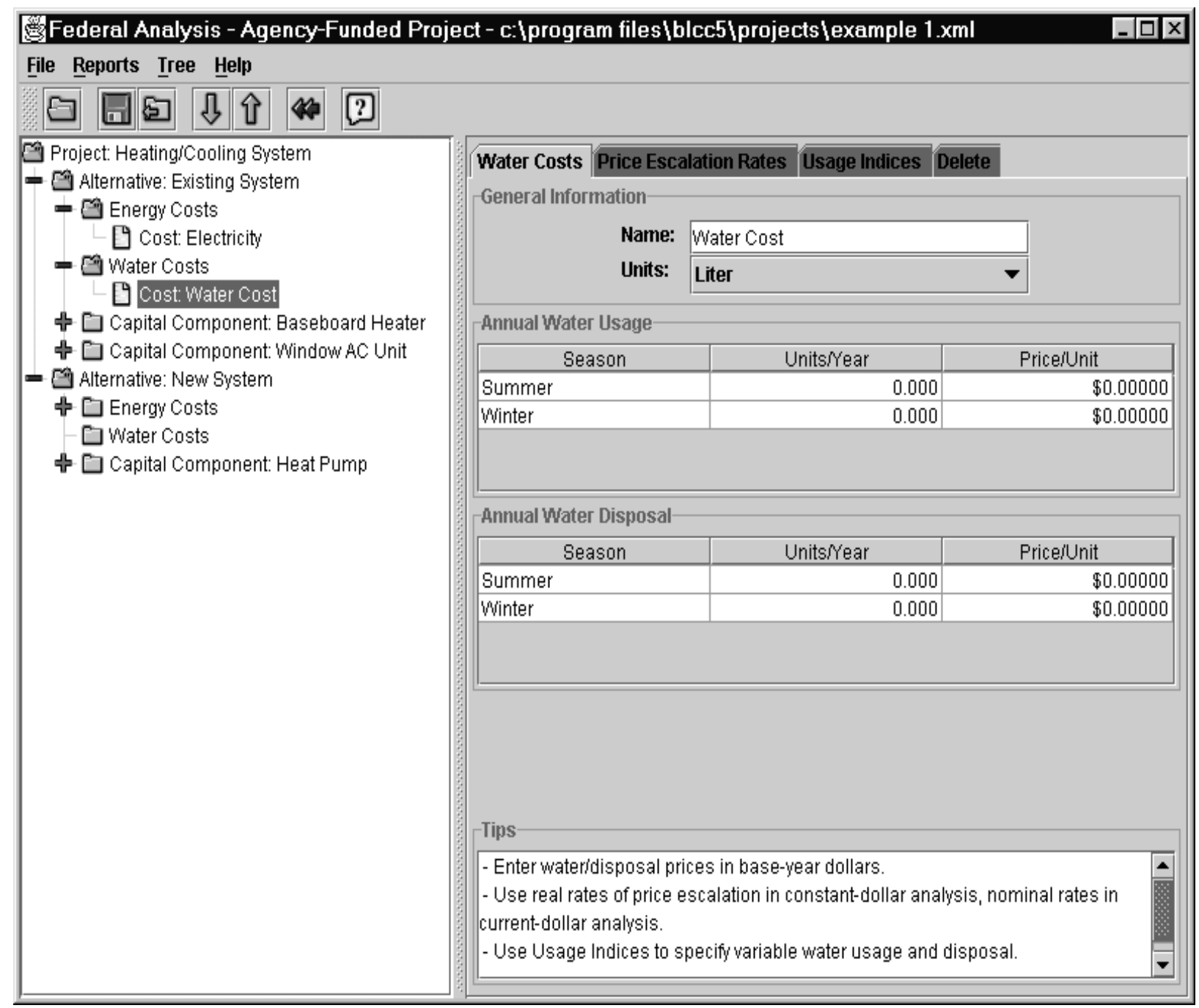




\section{Contract Costs}

\section{Annually Recurring}

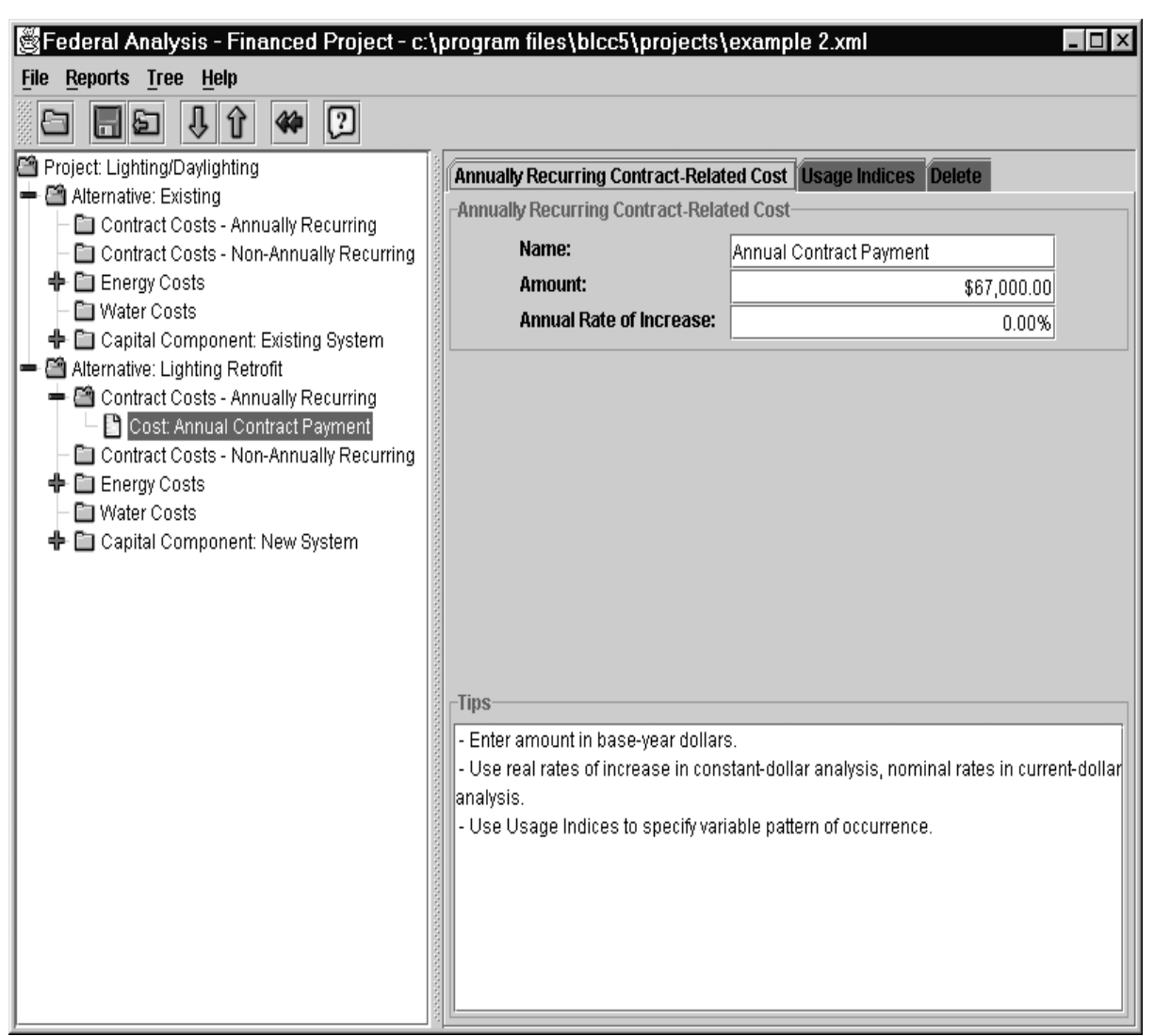

\section{Non-Annually Recurring}

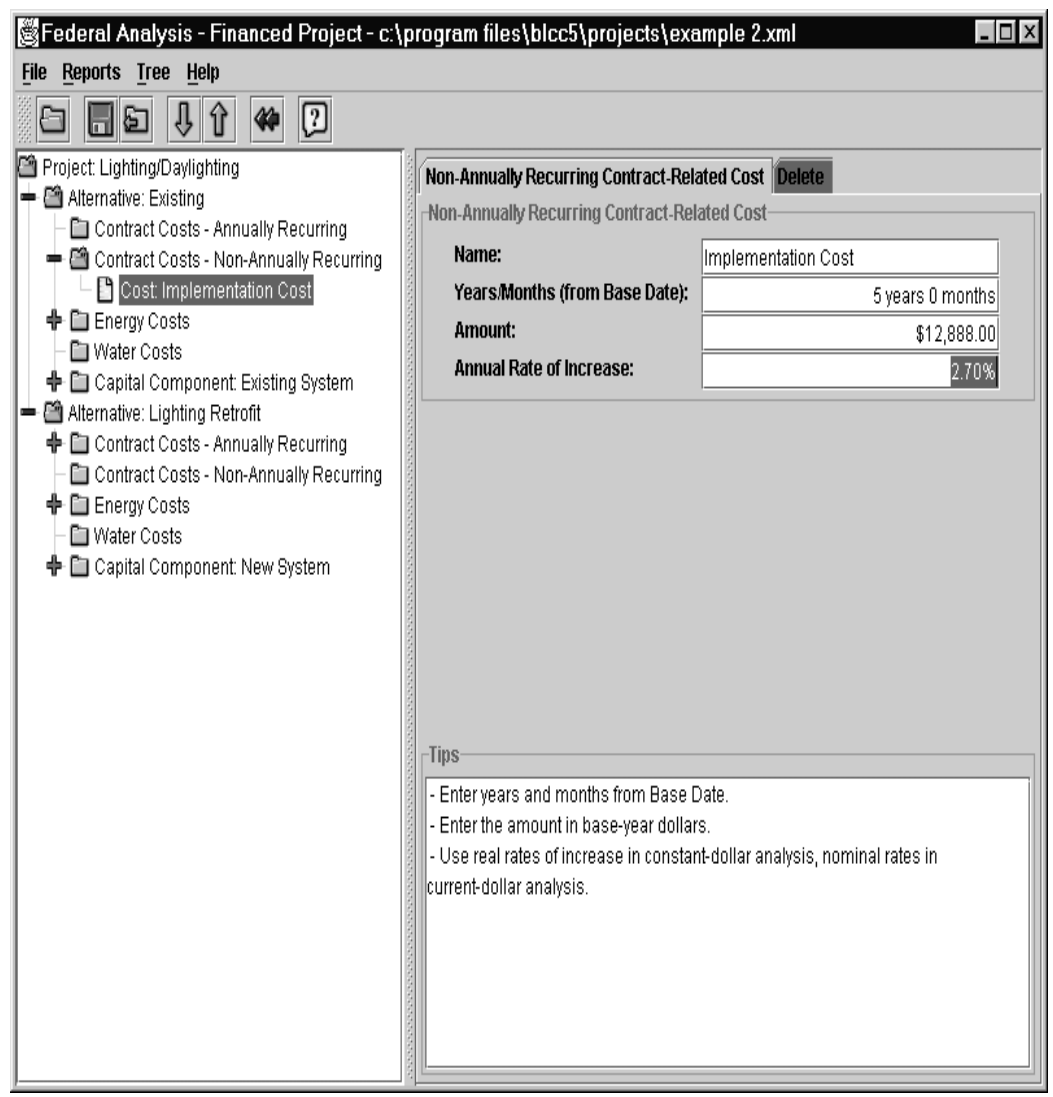




\section{Investment Costs}

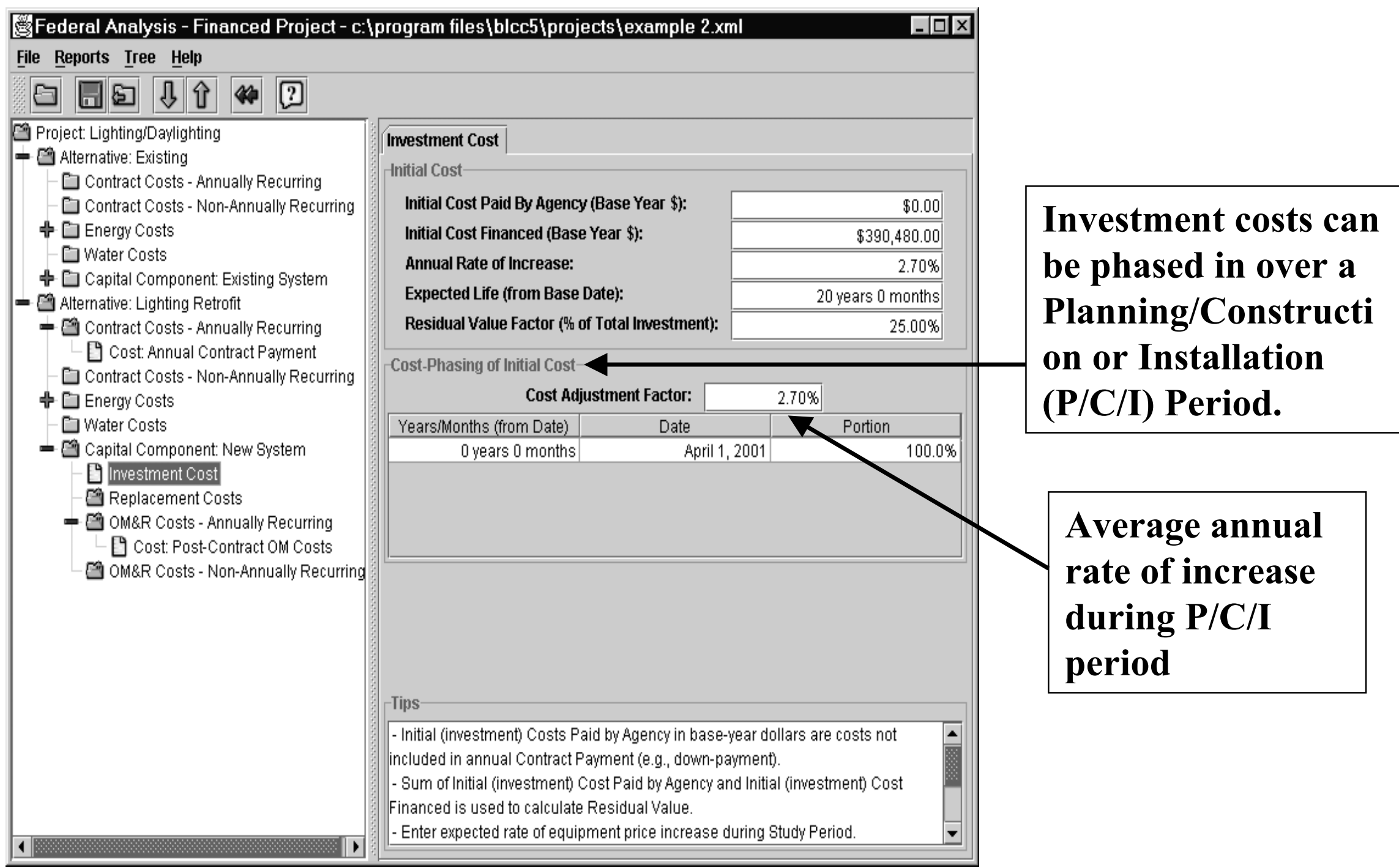




\section{Capital Replacement Costs}

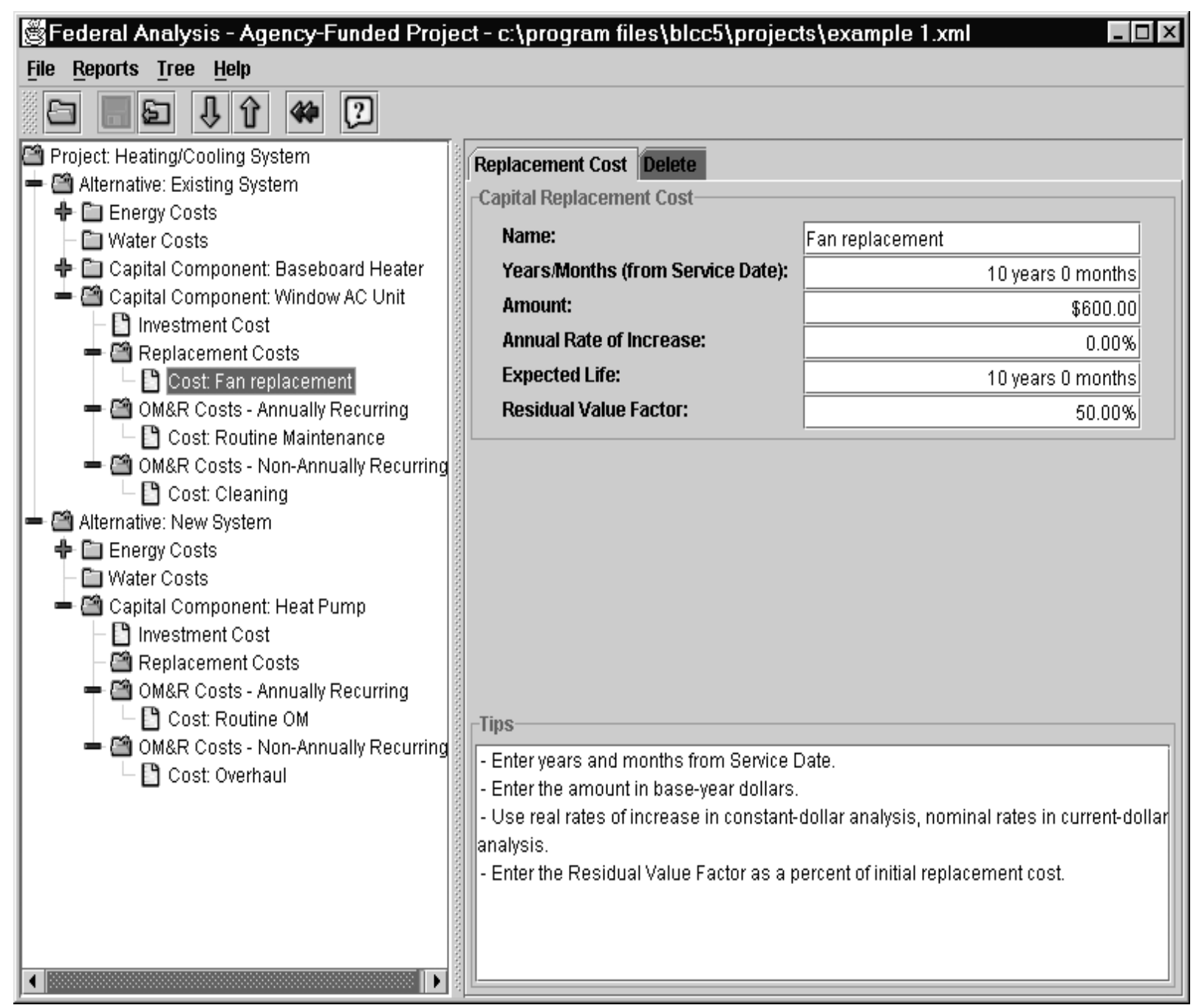




\section{Operating/Maintenance/Repair Costs}

\section{Annually Recurring}

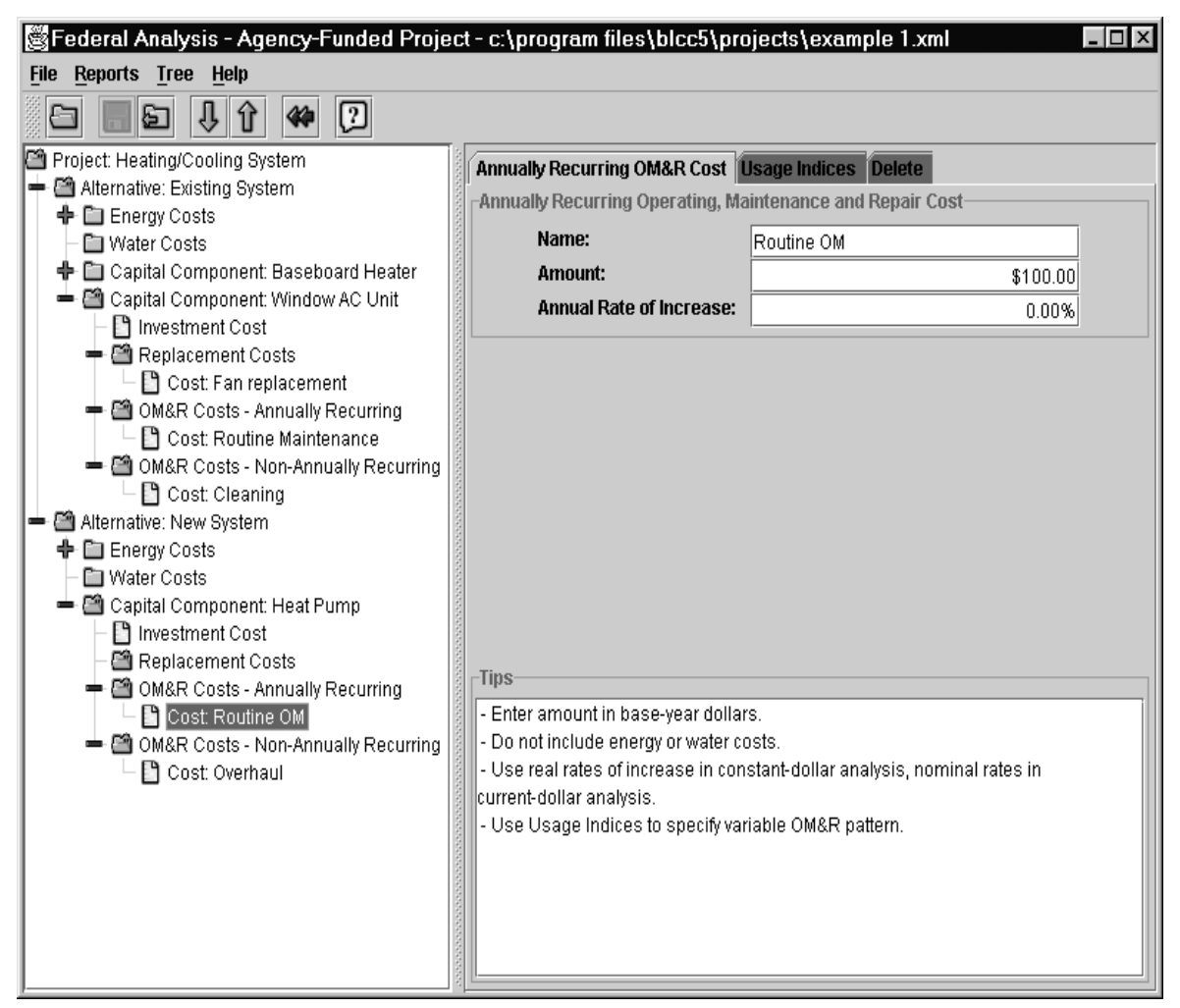

\section{Non-Annually Recurring}

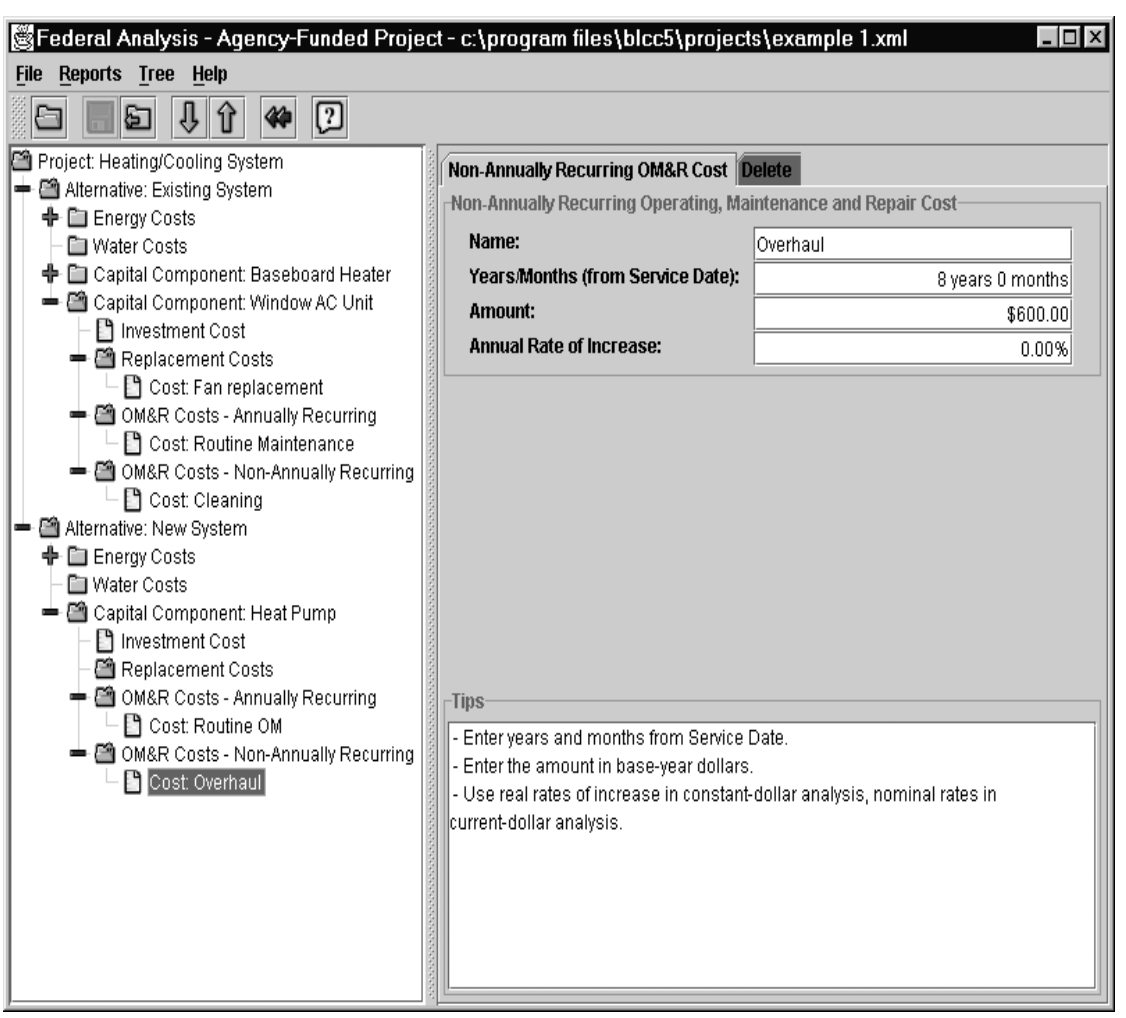




\section{BLCC5 Reports}

- For all alternatives in project

- input data listing

- life-cycle cost analysis (detailed and summary)

- yearly cash flow analysis

- Comparative analysis

- listing of LCCs for all project alternatives, with lowest LCC flagged

- comparative economic measures (alternative versus base case)

- side-by-side comparison of present values

- net savings

- savings-to-investment ratio

- adjusted internal rate of return

- payback

- energy savings

- emission reductions

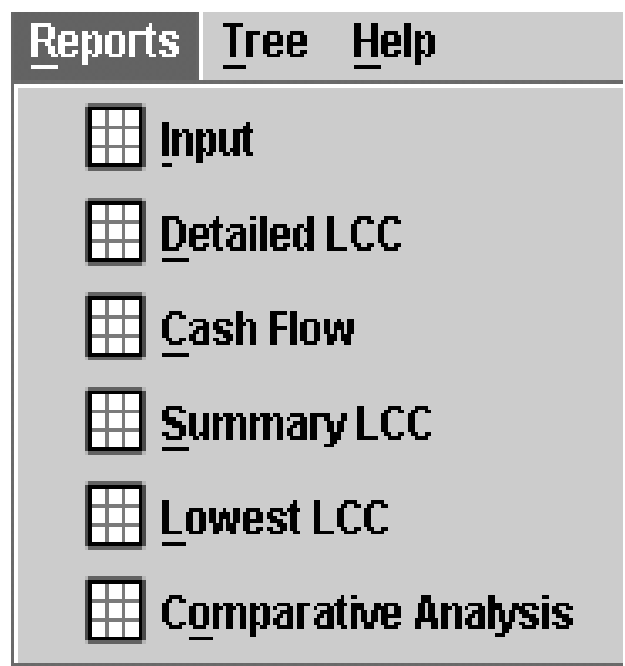




\section{Lowest LCC}

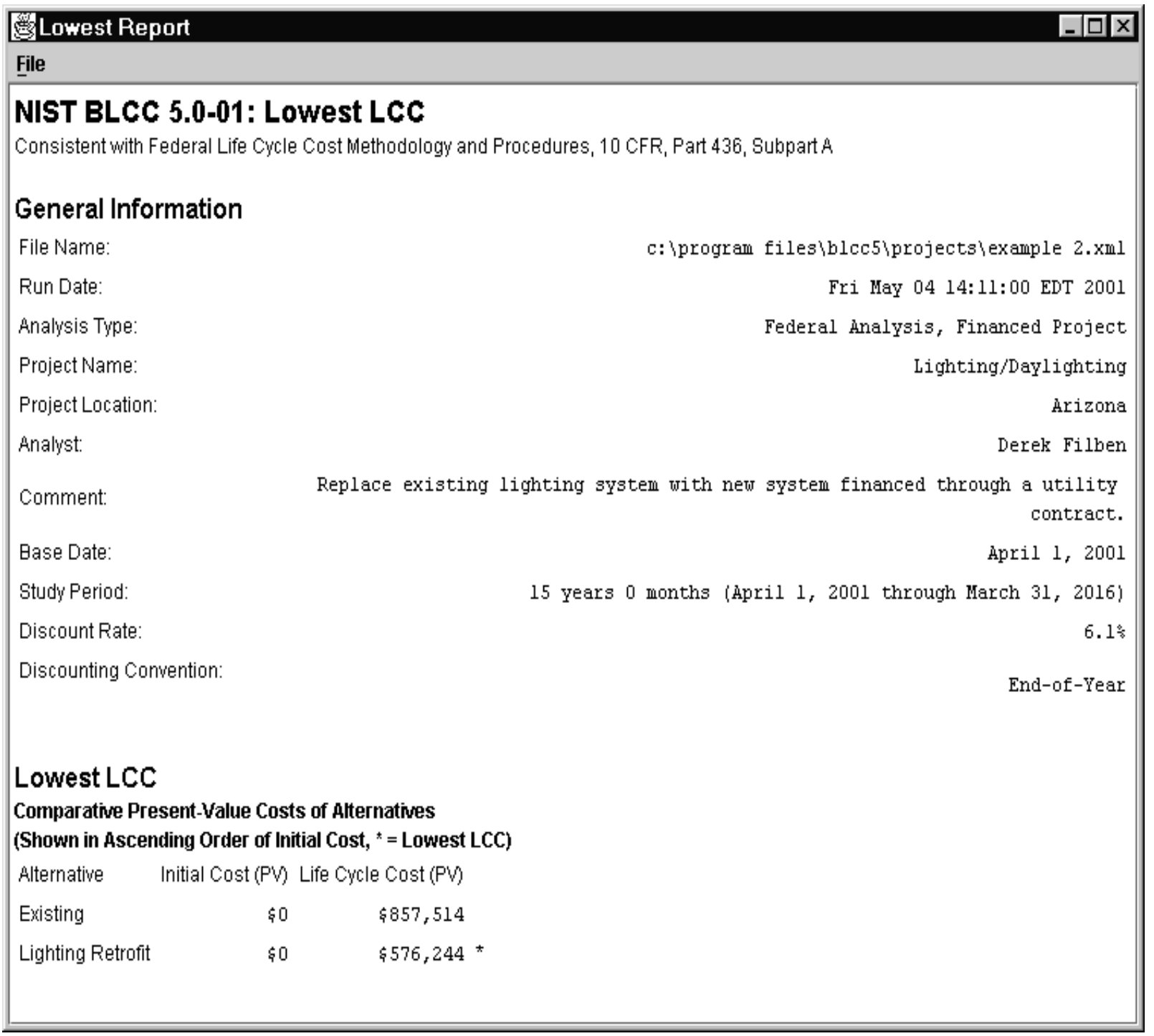




\section{NIST DOS-Based LCC Support Software}

- BLCC4

- ERATES: complex electricity rate schedules

- EMISS: air pollution emission factors

- DISCOUNT: present value factors and calculations 


\section{NIST LCC Programs}

- Programs updated every April 1 with new energy price escalation and discount rates

- Downloadable from DOE/FEMP Web site:

- www.eren.doe.gov/femp -- Technical Assistance Analytical Software Tools 



\section{Module C}

\section{Fuel Switching and Phased-In Capital Replacements}

Objective: Upon completion of this module, you will be able to

- evaluate capital replacements affecting energy types and energy usage amounts after occupancy. 


\section{Boiler Replacement Problem}

Location: Office building in Maryland

Existing: $\quad 3-700 \mathrm{kBtu}$ oil-fired boilers

$60 \%$ efficient, 15-year remaining life

oil price \$1.20/gallon (\$8.57 MBtu)

Proposal: $\quad 3-700 \mathrm{kBtu}$ gas/oil-fired boilers

$\$ 15,000$ each (installed)

80/83\% efficient, 30-year expected life

gas price $\$ 1.00 /$ therm $(\$ 10.00 \mathrm{MBtu})$

Maintenance similar for both systems

Annual heat load

$=2,065 \mathrm{MBtu}$

Study period

$=15$ years

FEMP LCC discount rate $=3.3 \%$ 


\section{Preliminary Analysis:}

\section{Replace All Three Boilers Immediately}

Calculate LCC of existing system.

$\mathrm{LCC}_{\text {existing }}=\mathrm{AL} / \mathbf{E f f}_{\text {existing }} \times \mathrm{P}_{\text {oil }} \times \mathrm{UPV}^{*}$

$\mathrm{LCC}_{\text {existing }}=2,065 / .60 \times \$ 8.57 \times 10.43$

$$
=\underline{\$ 307,634}
$$

Where:

$$
\text { IC = initial cost }
$$

AL = annual load

Eff = seasonal efficiency

$P=$ energy price (\$/MBtu)

$\mathrm{UPV}^{*}=$ modified uniform present value (commercial, region 3, oil or gas)

FR = residual value factor

SPV $=$ single present value factor

SP = study period 


\section{Preliminary Analysis (cont.): Replace All Three Boilers Immediately}

Calculate LCC of new boilers using both gas and oil.

$\mathbf{L C C}_{\text {new }}=\mathrm{IC}+\mathrm{AL} / \mathrm{Eff}_{\text {new }} \times \mathrm{P}_{\text {gas } / \text { oil }} \times \mathrm{UPV} *$

- IC x RF x SPV

$\mathrm{LCC}_{\text {new(gas) }}=\$ 45,000+2,065 / 0.80 \times \$ 10.00 \times 10.49$

- $\$ 45,000 \times 0.5 \times 0.614$

$=\underline{\$ 301,958}$

$\mathrm{LCC}_{\text {new(oil) }}=\$ 45,000+2,065 / 0.83 \times \$ 8.57 \times 10.43$

- $\$ 45,000 \times 0.5 \times 0.614$

$=\underline{\$ 253,571}$ 


\section{Phased-In Boiler Replacement}

Replace boiler \#1 immediately, \#2 at end of year 2,

\#3 at end of year 4.

$$
\begin{aligned}
& \mathrm{LCC}_{\text {new }}=\mathrm{IC}_{1} \times \mathrm{SPV}_{0}+\mathrm{IC}_{2} \times \mathrm{SPV}_{2}+\mathrm{IC}_{3} \times \mathrm{SPV}_{4}+ \\
& +\mathrm{AL}_{1} / \mathbf{E f f}_{\text {new }} \quad \times \mathbf{P}_{\text {oil }} \times \mathrm{UPV}_{(15,0 i 1, S, \text { com })} \\
& +\mathrm{AL}_{2} / \mathbf{E f f}_{\text {existing }} \times \mathbf{P}_{\text {oil }} \times \mathrm{UPV}^{*}{ }_{(2, \mathrm{oil}, \mathrm{S}, \mathrm{com})} \\
& +\mathrm{AL}_{2} / \mathrm{Eff}_{\text {new }} \quad x \mathbf{P}_{\text {oil }} \times\left[\mathrm{UPV}_{(15, \text { oil,S,com })-} \mathrm{UPV}_{(2,0 i l, S, \text { com })}\right] \\
& +\mathrm{AL}_{3} / \mathbf{E f f}_{\text {existing }} \times \mathbf{P}_{\text {oil }} \times \mathrm{UPV}^{*}{ }_{(4, \mathrm{oil}, \mathrm{S}, \mathrm{com})} \\
& +\mathrm{AL}_{3} / \mathbf{E f f}_{\text {new }} \quad x \mathbf{P}_{\text {oil }} \times\left[\mathrm{UPV}_{(15, \text { oil,S,com })-} \mathrm{UPV}_{(4, \mathrm{oil}, \mathrm{S}, \mathrm{com})}\right] \\
& -\mathrm{IC}_{1} \times \mathrm{RF}_{1} \times \mathrm{SPV}_{15}-\mathrm{IC}_{2} \times \mathrm{RF}_{2} \times \mathrm{SPV}_{15} \\
& -\mathrm{IC}_{3} \times \mathrm{RF}_{3} \times \mathrm{SPV}_{15}
\end{aligned}
$$




\section{Boiler Load Profile}

The annual load on each boiler $\left(\mathrm{AL}_{1}, \mathrm{AL}_{2}, \mathrm{AL}_{3}\right)$ is needed to identify energy use as boilers are phased in.

\begin{tabular}{|c|c|c|c|c|c|c|}
\hline \multirow{2}{*}{ bin } & $\begin{array}{c}\text { outdoor } \\
\text { temp }\end{array}$ & $\begin{array}{c}\text { load } \\
(\mathrm{kBtu})\end{array}$ & boiler 1 & boiler 2 & boiler 3 & $\begin{array}{c}\text { hrs/ } \\
\text { year }\end{array}$ \\
\hline 1 & 47 & 222 & 222 & 0 & 0 & 684 \\
\hline 2 & 42 & 444 & 444 & 0 & 0 & 790 \\
\hline 3 & 37 & 668 & 666 & 0 & 0 & 744 \\
\hline 4 & 32 & 889 & 700 & 189 & 0 & 542 \\
\hline 5 & 27 & 1111 & 700 & 411 & 0 & 254 \\
\hline 6 & 22 & 1333 & 700 & 633 & 0 & 138 \\
\hline 7 & 17 & 1556 & 700 & 700 & 156 & 54 \\
\hline 8 & 12 & 1778 & 700 & 700 & 378 & 17 \\
\hline 9 & 7 & 2000 & 700 & 700 & 600 & 2 \\
\hline
\end{tabular}




\section{Annual Energy Use by Individual Boiler}

\begin{tabular}{|c|c|c|c|c|}
\hline \multirow{2}{*}{ bin } & \multicolumn{3}{|c|}{ annual load (MBtu) } & total \\
\cline { 2 - 4 } & boiler 1 & boiler 2 & boiler 3 & load \\
\hline 1 & 152 & 0 & 0 & 152 \\
\hline 2 & 351 & 0 & 0 & 351 \\
\hline 3 & 496 & 0 & 0 & 496 \\
\hline 4 & 379 & 102 & 0 & 481 \\
\hline 5 & 178 & 104 & 0 & 282 \\
\hline 6 & 97 & 87 & 0 & 184 \\
\hline 7 & 38 & 38 & 8 & 84 \\
\hline 8 & 12 & 12 & 6 & 30 \\
\hline 9 & 1 & 2 & 1 & 4 \\
\hline Total & 1,704 & 345 & 15 & 2,064 \\
\hline
\end{tabular}




\section{LCC for Existing Boilers}

$\mathrm{LCC}_{\text {existing(i) }}=\mathrm{AL}_{1} / \mathrm{Eff}_{\text {existing }} \times \mathrm{P}_{\text {oil }} \times \mathrm{UPV}^{*}{ }_{15}$

$\mathrm{LCC}_{\text {existing(1) }}=1,704 / 0.60 \times \$ 8.57 \times 10.43=\$ 253,854$

$\mathrm{LCC}_{\text {existing(2) }}=345 / 0.60 \times \$ 8.57 \times 10.43=\$ 51,396$

$\mathrm{LCC}_{\text {existing(3) }}=\quad 15 / 0.60 \times \$ 8.57 \times 10.43=\$ 2,235$ 


\section{LCC for New Boilers (individual)}

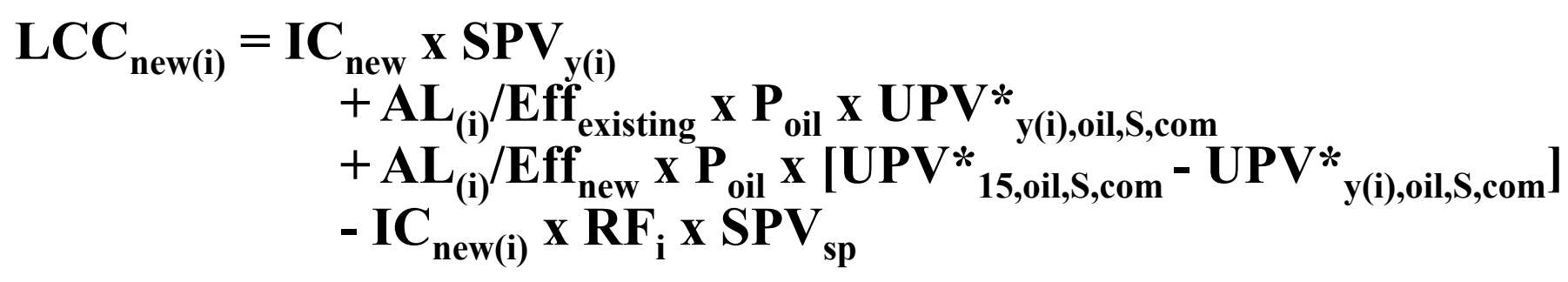

$\mathrm{LCC}_{\text {new(1) }}=\$ 15,000 \times 1.0$

$+1,704 / 0.60 \times \$ 8.57 \times 0.0$

$+1,704 / 0.83 \times \$ 8.57 \times(10.43-0.0)$

$+\$ 15,000 \times 0.50 \times 0.614=\$ 193,904$

$\mathrm{LCC}_{\text {new(2) }}=\$ 15,000 \times 0.937$

$+345 / 0.60 \times \$ 8.57 \times 1.68$

$+345 / 0.83 \times \$ 8.57 \times(10.43-1.68)$

$+\$ 15,000 \times 0.57 \times 0.614=\$ 48,253$

$\mathrm{LCC}_{\text {new(3) }}=\$ 15,000 \times 0.878$

$+15 / 0.60 \times \$ 8.57 \times 3.23$

$+15 / 0.83 \times \$ 8.57 \times(10.43-3.23)$

$+\$ 15,000 \times 0.63 \times 0.614=\$ 9,147$ 


\section{Lowest LCC and Net Savings}

\begin{tabular}{|c|c|c|c|}
\hline Boiler \# & Existing LCC & New LCC & Net Savings \\
\hline 1. & $\$ 253,854$ & $\$ 193,904$ & $\$ 59,950$ \\
\hline 2. & $\$ 51,396$ & $\$ 48,253$ & $\$ 3,143$ \\
\hline 3. & $\$ 2,235$ & $\$ 9,147$ & $-\$ 6,912$ \\
\hline
\end{tabular}




\section{Oil Only Versus Gas/Oil Boiler}

A single-fuel, oil-fired boiler costs $\$ 10,000$; all other costs are the same. Is it more cost-effective?

Calculate LCC of new oil-fired boilers.

$\begin{aligned} \mathbf{L C C}_{\text {new }}= & \mathrm{IC}+\mathrm{AL} / \mathrm{Eff}_{\text {new }} \times \mathrm{P}_{\text {oil }} \times \mathrm{UPV}^{*} \\ & -\mathrm{IC} \times \operatorname{RF} \times \operatorname{SPV}_{\mathrm{sp}}\end{aligned}$

$\mathrm{LCC}_{\text {new(oil) }}=\$ 30,000+2,065 / 0.83 \times \$ 8.57 \times 10.43$

- \$30,000 x 0.5 x 0.614

$=\underline{\$ 243,176}$ 


\section{Lowest Life-Cycle Cost}

\begin{tabular}{|l|c|}
\hline \multicolumn{1}{|c|}{ Option } & LCC \\
\hline Existing Oil-Fired Boiler & $\$ 307,634$ \\
\hline New Gas/Oil-Fired Boiler & $\$ 253,571$ \\
\hline New Oil-Fired Boiler & $\$ 243,176$ \\
\hline
\end{tabular}

What other issues need enter into the decision other than lowest LCC? 


\section{Exercise C1}

Determine the LCC, using BLCC5, for the following three cases:

Location:

Annual heat load:

Study period:

FEMP discount rate:

Oil price:

Gas price:
Office building in Maryland

2,065 MBtu

15 years

$3.3 \%$

\$1.20/gallon, 140,000 Btu/gallon

$\$ 1.00 /$ therm, 100,000 Btu/therm

Maintenance similar for all options. 


\section{Exercise C1 (cont.)}

Case 1: $\quad$ Existing 3 - $700 \mathrm{kBtu}$ oil-fired boilers $60 \%$ efficient, 15-year remaining life

Case 2: $\quad$ New 3 - 700 kBtu gas/oil-fired boilers $\$ 15,000$ each, 80/83\% (gas/oil) efficient 30-year expected life, fired-on oil

Case 3: New 3 - 700 kBtu gas/oil-fired boilers $\$ 15,000$ each, $80 / 83 \%$ (gas/oil) efficient 30-year expected life, fired-on gas 


\section{Annual Energy Use}

\begin{tabular}{|c|c|c|}
\hline Case \# & & Energy Use \\
\hline 1 & $2,065 \times 10^{6} /(140,000 \times .60)$ & 24,583 gallons \\
\hline 2 & $2,065 \times 10^{6} /(140,000 \times .83)$ & 17,771 gallons \\
\hline 3 & $2,065 \times 10^{6} /(100,000 \times .80)$ & 25,813 therms \\
\hline
\end{tabular}




\section{Alternative 1 - Existing Oil-Fired Boilers}

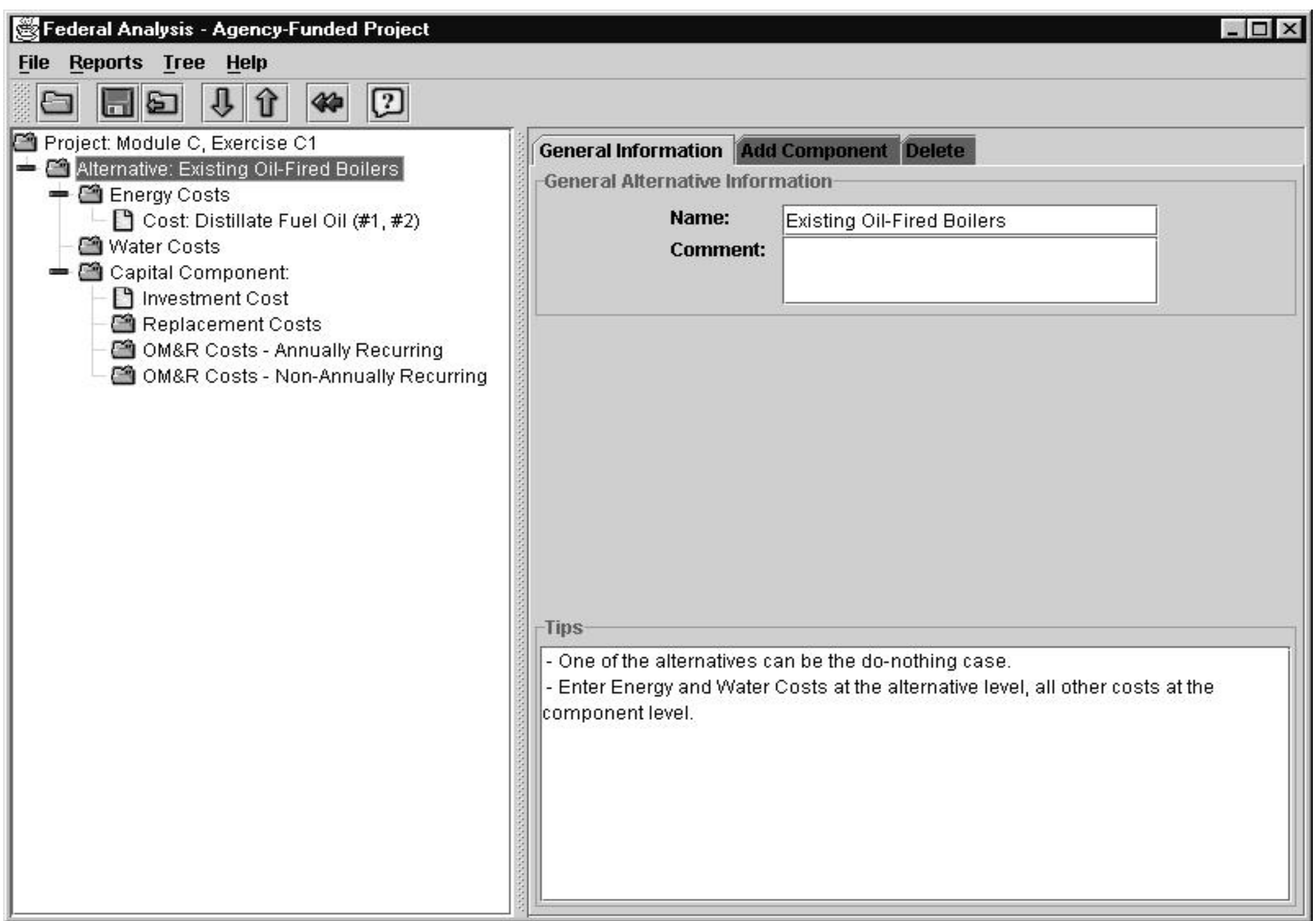




\section{Choose the Fuel Type}

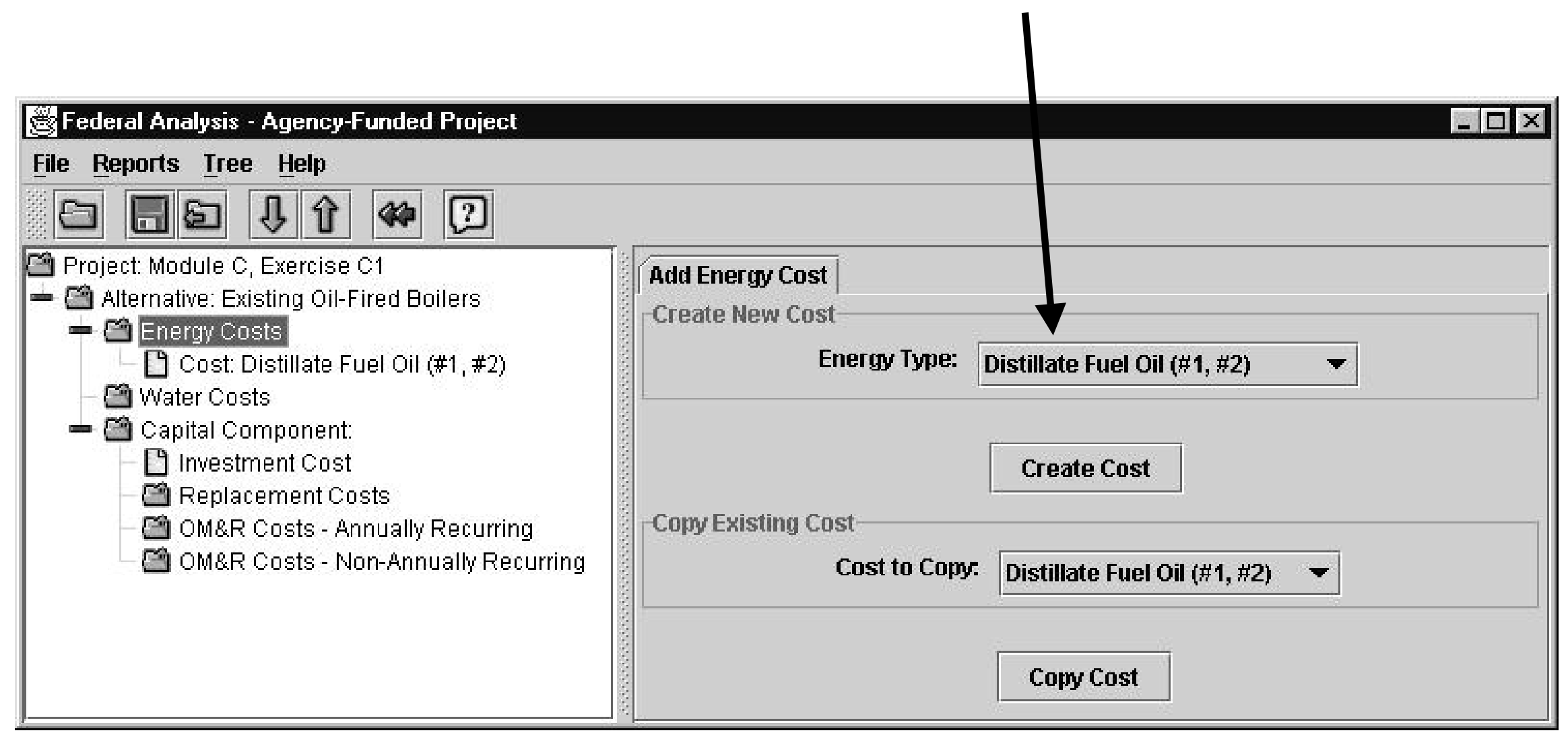




\section{Enter the Annual Consumption}

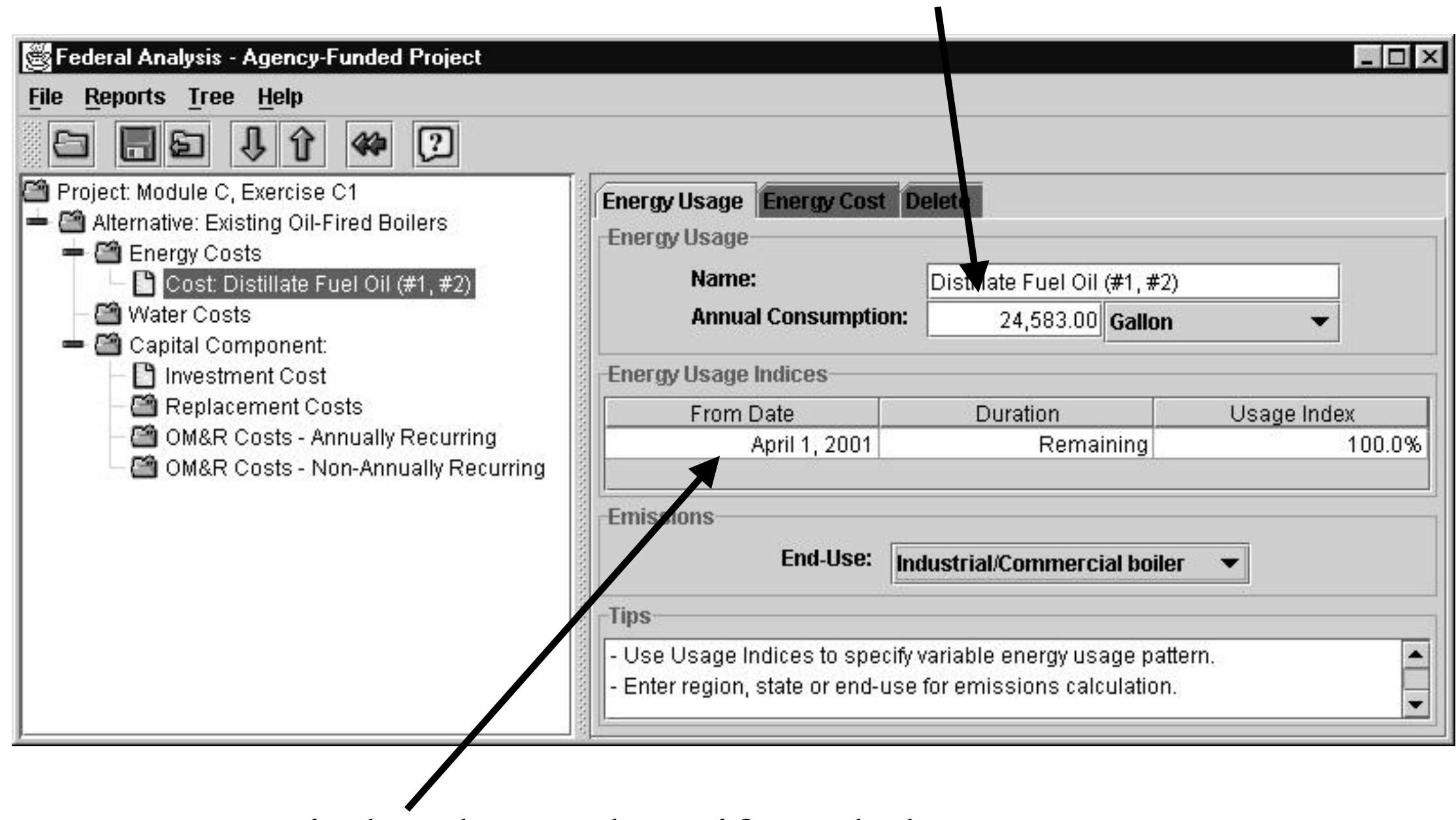

You can index the use here if needed. 


\section{Enter the Fuel Price and}

Escalation Information






\section{Review the Summary LCC Report}

\begin{tabular}{|c|c|c|c|}
\hline Summary Report & & & - \\
\hline File & & & \\
\hline Alternative: Existing Oil & Fired Boil & & 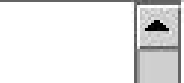 \\
\hline & Present value & Annual Value & \\
\hline Initial Cost & $\$ 0$ & $\$ 0$ & \\
\hline Energy Consumption Costs & $\$ 307,639$ & $\$ 26,335$ & \\
\hline Energy Demand Costs & $\$ 0$ & $\$ 0$ & \\
\hline Energy Utility Rebates & $\$ 0$ & $\$ 0$ & \\
\hline Water Usage Costs & $\$ 0$ & $\$ 0$ & 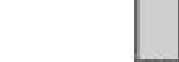 \\
\hline Water Disposal Costs & $\$ 0$ & $\$ 0$ & \\
\hline Annually Recurring OM\&R costs & $\$ 0$ & \$0 & \\
\hline Non-Annually Recurring OM\&R Costs & $\$ 0$ & $\$ 0$ & \\
\hline Replacement Costs & $\$ 0$ & $\$ 0$ & \\
\hline Less Remaining Value & $\$ 0$ & $\$ 0$ & \\
\hline Total Life-Cycle cost & $\$ 307,639$ & $\$ 26,335$ & $=$ \\
\hline
\end{tabular}




\section{Alternative 2 - Gas/Oil Boilers Burning Oil, Created by Copying Alternative 1 ,}

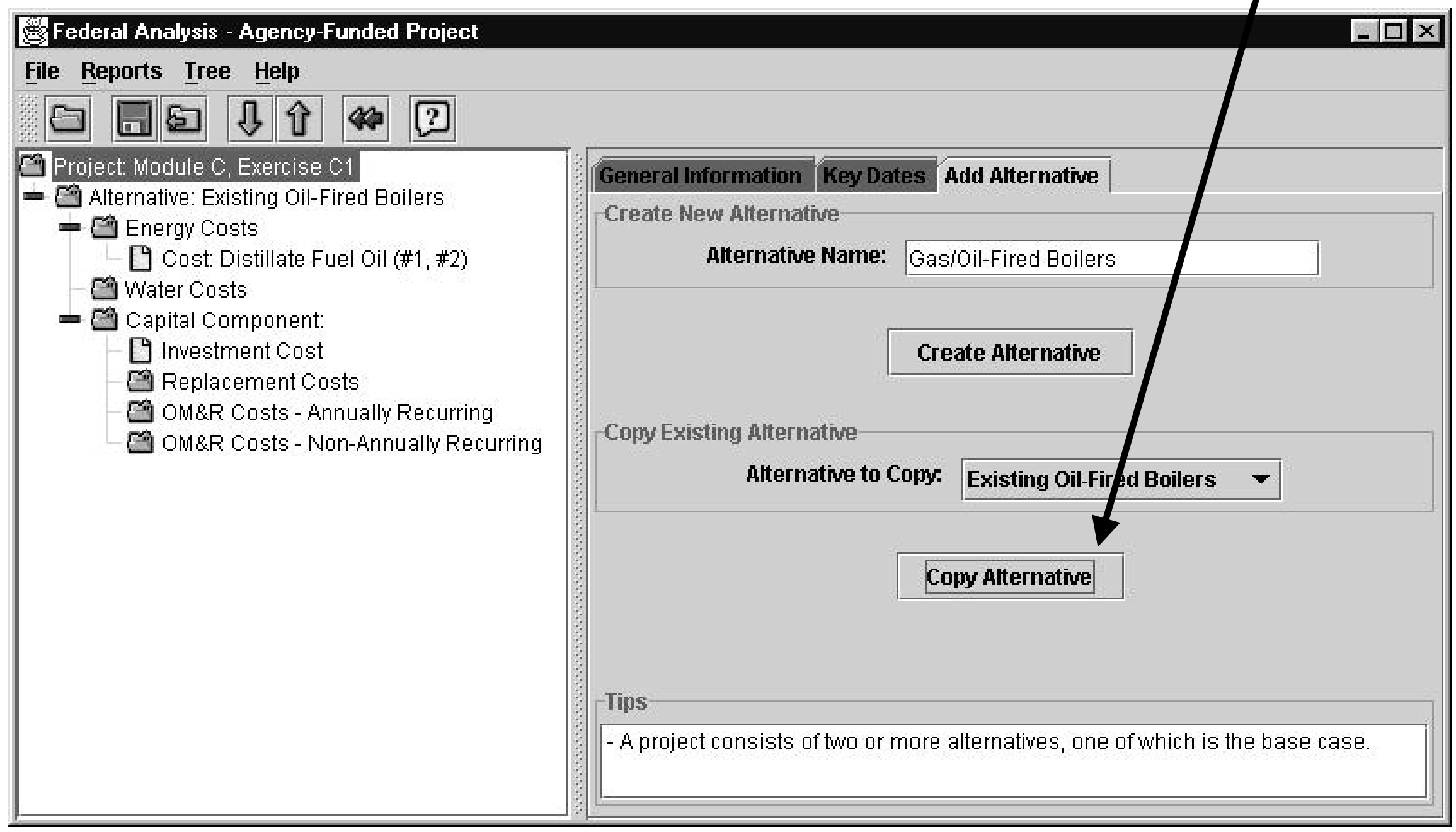




\section{Enter New Energy Use Data}

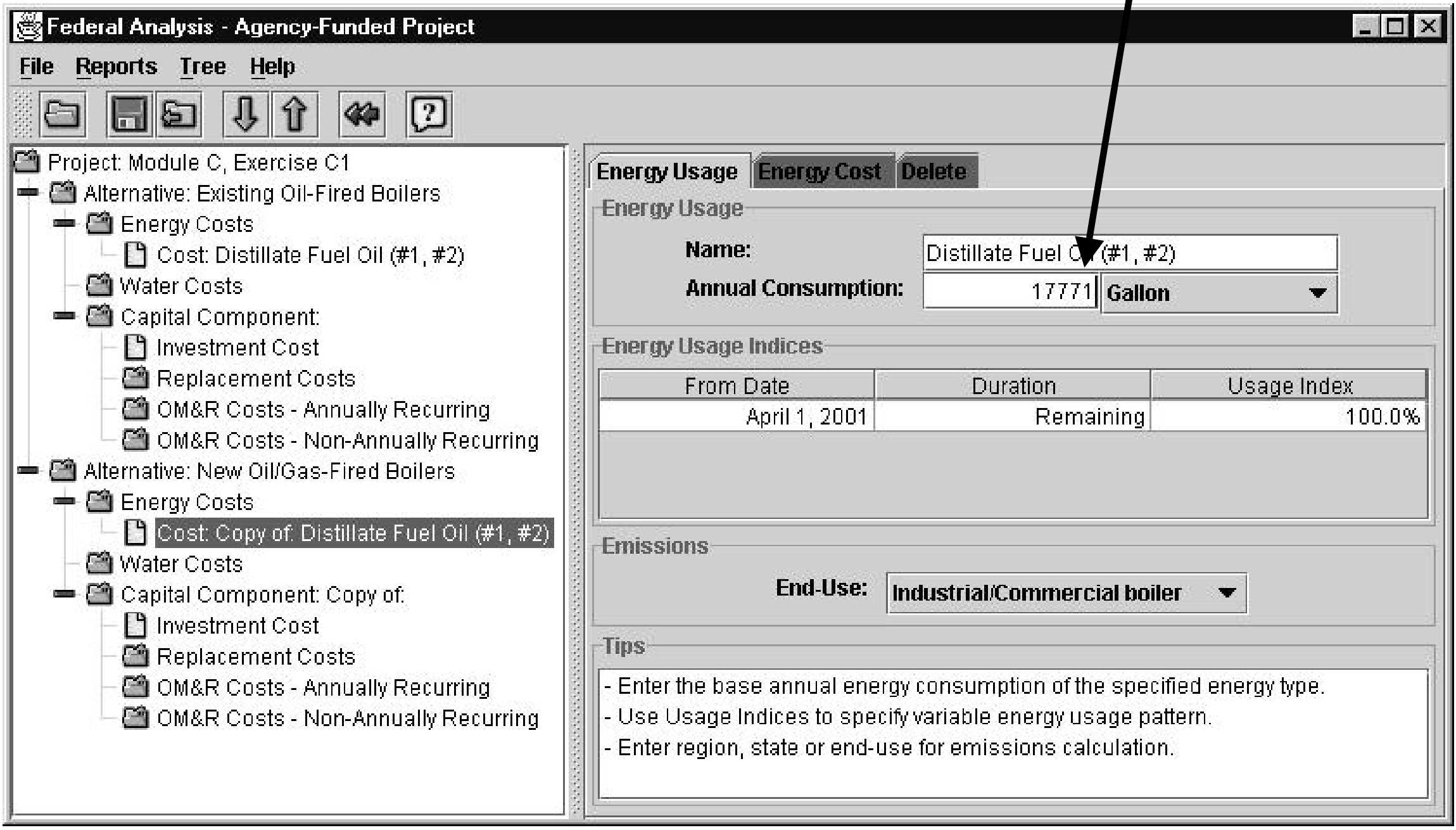




\section{Enter Initial Cost, Life, and}

Residual Value

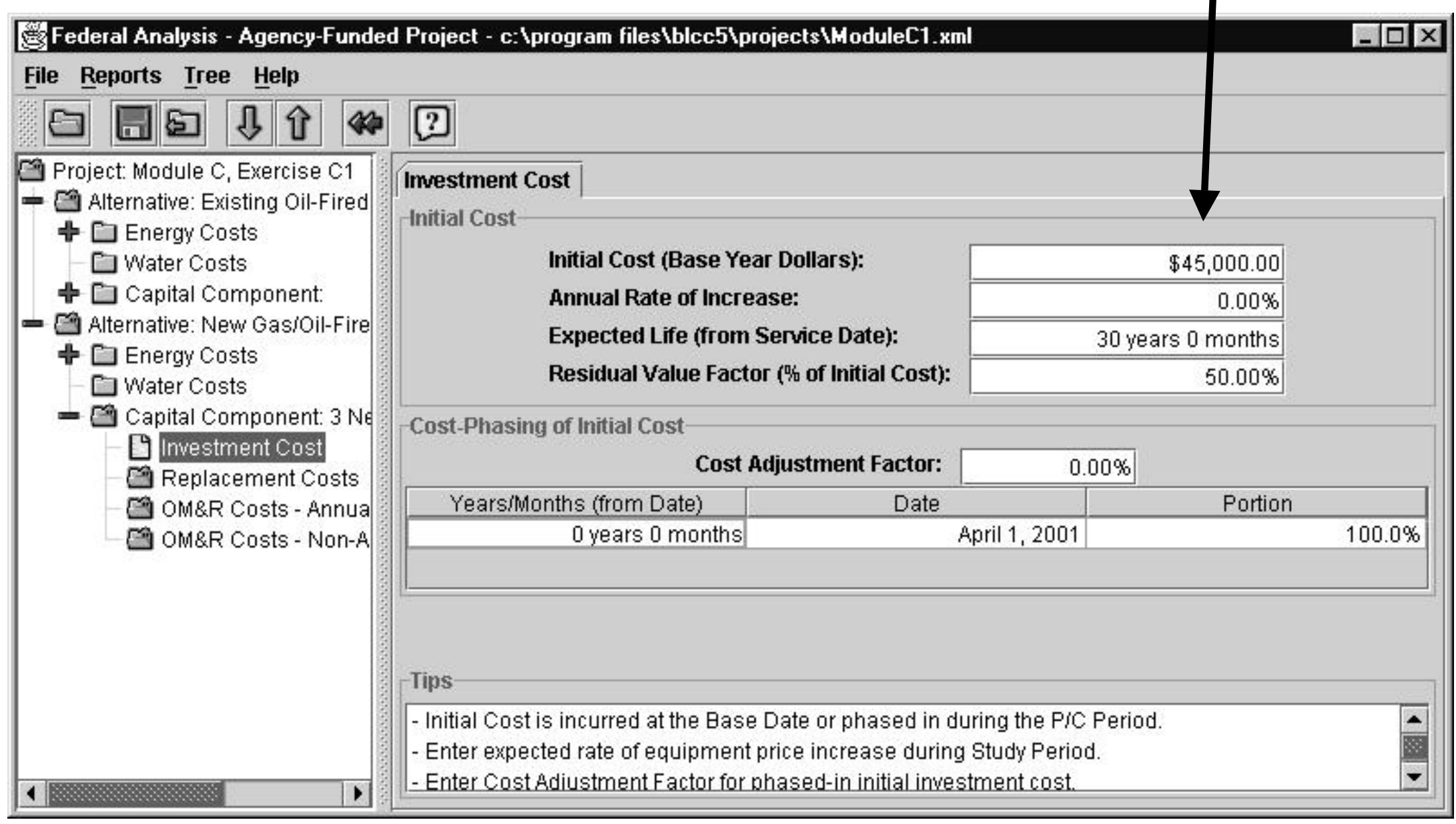




\section{Review the Summary LCC Report}

\begin{tabular}{|c|c|c|c|}
\hline Summary Report & & & 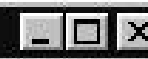 \\
\hline File & & & \\
\hline & & &  \\
\hline $\begin{array}{l}\text { Alternative: New GasiOi } \\
\text { Lcc summary }\end{array}$ & l-Fired Boi & ers on Oil & \\
\hline & Present Value & Annual Value & \\
\hline Initial Cost & $\$ 45,000$ & $\$ 3,852$ & \\
\hline Energy Consumption Costs & $\$ 222,391$ & $\$ 19,038$ & \\
\hline Energy Demand Costs & $\$ 0$ & $\$ 0$ & \\
\hline Energy Utility Rebates & $\$ 0$ & $\$ 0$ & \\
\hline Water Usage Costs & $\$ 0$ & $\$ 0$ & \\
\hline Water Disposal Costs & $\$ 0$ & $\$ 0$ & \\
\hline Annually Recurring OM\&R Costs & $\$ 0$ & $\$ 0$ & \\
\hline Non-Annually Recurring OM\&R Costs & $\$ 0$ & $\$ 0$ & 廆 \\
\hline Replacement Costs & $\$ 0$ & $\$ 0$ & \\
\hline Less Remaining Value & $-\$ 13,826$ & $-\$ 1,184$ & \\
\hline Total Life-Cycle cost & $\$ 253,565$ & $\$ 21,706$ & \\
\hline
\end{tabular}




\section{Analyze Alternative 3 and Review Results}

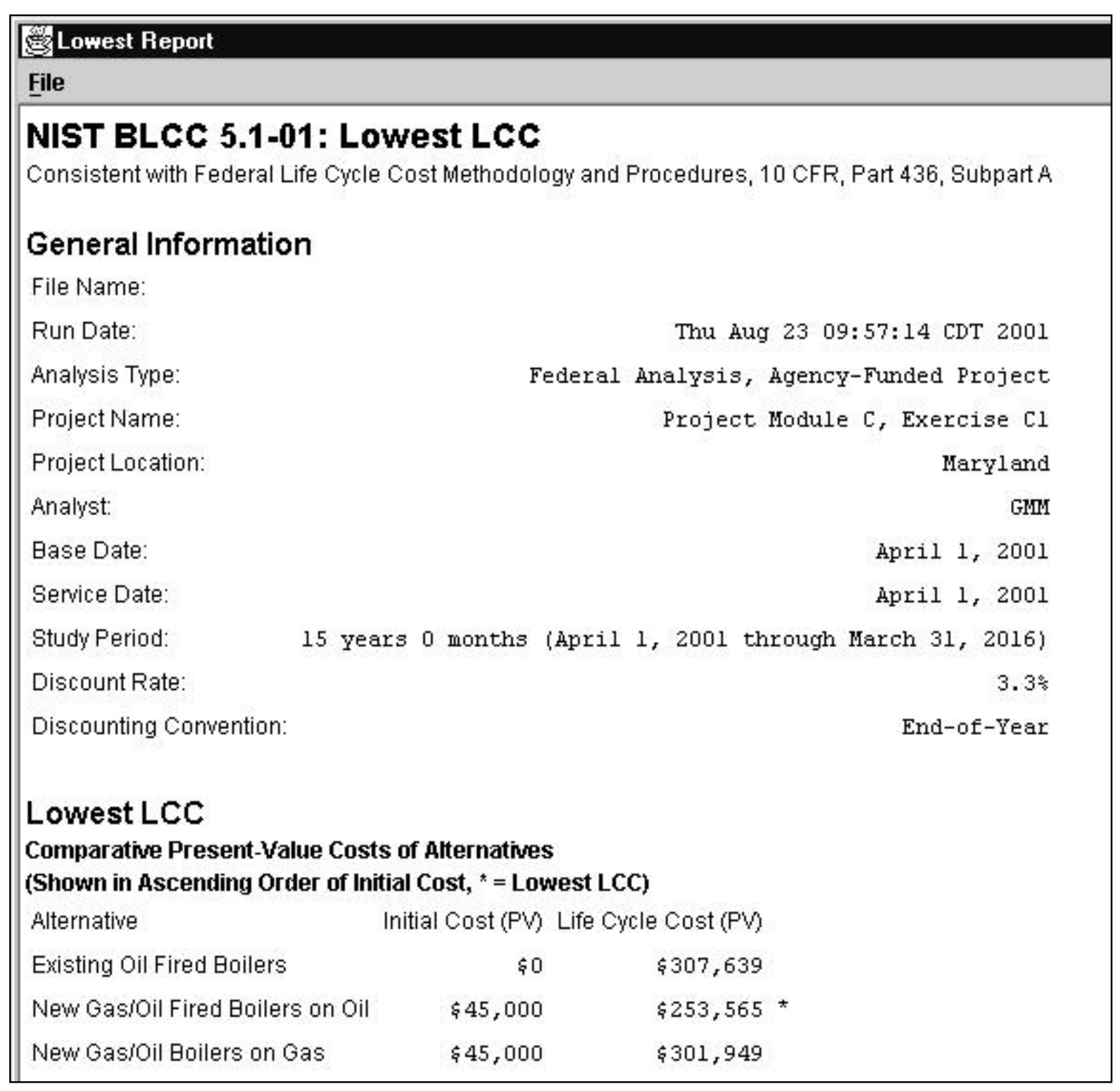




\section{Class Exercise C2}

The owner of a commercial building in Maryland is considering the replacement of three, older inefficient $(60 \%)$ distillate fuel oil-fired boilers with newer, more efficient $(83 \%)$ boilers. The annual heat load on the building is 2,065 MBtu distributed over the three boilers. \#2 oil has a heating value of $140,000 \mathrm{Btu} / \mathrm{gal}$ and presently costs $\$ 1.20$ per gallon.

Because of cash flow, the owner has decided she cannot afford to replace all three at the same time. Her schedule is to replace one boiler now, another at the end of year two, and a third at the end of year four.

The boiler control system presently stages one boiler on until it can no longer meet the load and then adds another boiler. Using this strategy, the lead boiler meets 1,704 MBtu of the load, the second boiler meets $345 \mathrm{MBtu}$, and the last boiler only comes on to meet $15 \mathrm{MBtu}$ of the load.

She plans to use the first new boiler installed as the lead boiler.

Compare the life-cycle cost of this approach against the status quo. Use a 15 -year study period and assume a 30-year life for the new boilers. The base date is specified as June 2001. Use the end-of-year discounting convention.

Hint: You will need to determine the oil use of each boiler during the construction period and use the energy-indexing feature of BLCC5. You will also need to determine the remaining life of each new boiler for residual value calculation. 


\section{Class Exercise C2 (cont.)}

\begin{tabular}{|c|c|c|c|c|c|c|c|}
\hline Boiler \# & $\begin{array}{c}\text { Annual } \\
\text { Load } \\
\text { MBtu }\end{array}$ & $\begin{array}{c}\text { Fuel Used } \\
\text { Gallons }\end{array}$ & Year 1 & Year 2 & Year 3 & Year 4 & $\begin{array}{c}\text { Year 5 } \\
\text { through 15 }\end{array}$ \\
\hline 1 old & 1,704 & 20,286 & & & & & \\
\hline 2 old & 345 & 4,107 & 4,107 & 4,107 & & & \\
\hline 3 old & 15 & 179 & 179 & 179 & 179 & 179 & \\
\hline & Total $=$ & 24,571 & & & & & \\
\hline 1 new & 1,704 & 14,664 & 14,664 & 14,664 & 14,664 & 14,664 & 14,664 \\
\hline 2 new & 345 & 2,969 & & & 2,969 & 2,969 & 2,969 \\
\hline 3 new & 15 & 129 & & & & & 129 \\
\hline & Total $=$ & 17,762 & 18,950 & 18,950 & 17,812 & 17,812 & 17,762 \\
\hline & & Fraction & 1 & 1 & 0.940 & 0.940 & 0.937 \\
\hline
\end{tabular}

\begin{tabular}{|c|c|c|c|}
\hline Boiler & Life Used & Life Left & $\begin{array}{c}\text { Residual Value } \\
\text { Factor }\end{array}$ \\
\hline 1 & 15 & 15 & 0.50 \\
\hline 2 & 13 & 17 & 0.57 \\
\hline 3 & 11 & 19 & 0.63 \\
\hline
\end{tabular}




\section{Solution to Class Exercise C2}

NIST BLCC 5.0-01: Input Data Listing

\section{General Information}

File Name:

Run Date:

Analysis Type:

Project Name:

Project Location:

Analyst:

Comment:

Base Date:

Service Date:

Study Period:

Discount Rate:

Discounting Convention:
C: $\backslash$ Program Files $\backslash B L C C 5 \backslash$ projects $\backslash$ Class Exercise C2.xml

Thu Sep 20 10:34:35 EDT 2001

Federal Analysis, Agency-Funded Project

Class Exercise C2

Maryland

Gene Meyer

Phased Boiler Replacement Versus Base Case of Do Nothing

June 1, 2001

June 1, 2001

15 years 0 months (June 1, 2001 through May 31, 2016)

End-of-Year

Discount and Escalation Rates are REAL (exclusive of general inflation)

\section{Alternative: Existing 60\% Boilers}

Energy: Distillate Fuel Oil (\#1, \#2)

$\begin{array}{lr}\text { Annual Consumption: } & 24,571.0 \mathrm{Gal} \\ \text { Price per Unit: } & \$ 1.20000 \\ \text { Demand Charge: } & \$ 0 \\ \text { Utility Rebate: } & \$ 0 \\ \text { End-Use: } & \text { Industrial/Commercial boiler } \\ \text { Rate Schedule: } & \text { Commercial } \\ \text { State: } & \text { Maryland }\end{array}$

Usage Indices

From Date Duration Usage Index

June 1, 2001 Remaining 100\%

Escalation Rates

$\begin{array}{cc}\text { From Date } \quad \text { Duration } & \text { Escalation } \\ \text { April 1, 2001 } 1 \text { year } 0 \text { months } & -9.59 \% \\ \text { April 1, 2002 1 year 0 months } & -5.10 \% \\ \text { April 1, 2003 1 year 0 months } & 0.65 \% \\ \text { April 1, 2004 1 year 0 months } & 0.64 \% \\ \text { April 1, 2005 1 year 0 months } & -1.27 \% \\ \text { April 1, 2006 1 year 0 months } & 1.29 \% \\ \text { April 1, 2007 1 year 0 months } & 0.64 \% \\ \text { April 1, 2008 1 year 0 months } & 0.84 \% \\ \text { April 1, 2009 1 year 0 months } & 1.67 \%\end{array}$


April 1, 20101 year 0 months

April 1, 20111 year 0 months

April 1, 20121 year 0 months

April 1, 20131 year 0 months

April 1, 20141 year 0 months

April 1, 20151 year 0 months

April 1, 20161 year 0 months

April 1, 20171 year 0 months

April 1, 20181 year 0 months

April 1, 20191 year 0 months

April 1, 20201 year 0 months

April 1, 20211 year 0 months

April 1, 20221 year 0 months

April 1, 20231 year 0 months

April 1, 20241 year 0 months

April 1, 20251 year 0 months

April 1, 20261 year 0 months

April 1, 20271 year 0 months

April 1, 20281 year 0 months

April 1, 20291 year 0 months

April 1, 20301 year 0 months

April 1, 2031 Remaining
$0.62 \%$
$0.82 \%$
$1.01 \%$
$0.60 \%$
$2.59 \%$
$1.36 \%$
$0.77 \%$
$0.95 \%$
$1.13 \%$
$1.12 \%$
$0.37 \%$
$0.18 \%$
$0.37 \%$
$0.37 \%$
$0.36 \%$
$0.36 \%$
$0.36 \%$
$0.36 \%$
$0.36 \%$
$0.18 \%$
$0.36 \%$
$0.32 \%$

\section{Component:}

\section{Initial Investment}

Initial Cost (base-year \$): $\quad \$ 0$

Annual Rate of Increase: $\quad 0 \%$

Expected Asset Life: $\quad 0$ years 0 months

Residual Value Factor: $\quad 0 \%$

Cost-Phasing

Cost Adjustment Factor: 0\%

Years/Months (from Date) Date Portion

O years 0 months June 1, $2001 \quad 100 \%$

\section{Alternative: Phased Boiler Replacement}

\section{Energy: Distillate Fuel Oil (\#1, \#2)}

$\begin{array}{lr}\text { Annual Consumption: } & 18,950.0 \text { Therm } \\ \text { Price per Unit: } & \$ 1.20000 \\ \text { Demand Charge: } & \$ 0 \\ \text { Utility Rebate: } & \$ 0 \\ \text { End-Use: } & \text { Industrial/Commercial boiler } \\ \text { Rate Schedule: } & \text { Commercial } \\ \text { State: } & \text { Maryland }\end{array}$




\section{Usage Indices}

$\begin{array}{ccr}\text { From Date } & \text { Duration } & \text { Usage Index } \\ \text { June 1, 2001 } 2 \text { years 0 months } & 100 \% \\ \text { June 1, 2003 } 2 \text { years 0 months } & 94 \% \\ \text { June 1, 2005 } & \text { Remaining } & 93.7 \%\end{array}$

\section{Escalation Rates}

From Date Duration Escalation

April 1, 20011 year 0 months $\quad-9.59 \%$

April 1, 20021 year 0 months $\quad-5.10 \%$

April 1, 20031 year 0 months $\quad 0.65 \%$

April 1, 20041 year 0 months $\quad 0.64 \%$

April 1, 20051 year 0 months $\quad-1.27 \%$

April 1, 20061 year 0 months $\quad 1.29 \%$

April 1, 20071 year 0 months $\quad 0.64 \%$

April 1, 20081 year 0 months $\quad 0.84 \%$

April 1, 20091 year 0 months $\quad 1.67 \%$

April 1, 20101 year 0 months $\quad 0.62 \%$

April 1, 20111 year 0 months $\quad 0.82 \%$

April 1, 20121 year 0 months $\quad 1.01 \%$

April 1, 20131 year 0 months $\quad 0.60 \%$

April 1, 20141 year 0 months $\quad 2.59 \%$

April 1, 20151 year 0 months $\quad 1.36 \%$

April 1, 20161 year 0 months $\quad 0.77 \%$

April 1, 20171 year 0 months $\quad 0.95 \%$

April 1, 20181 year 0 months $1.13 \%$

April 1, 20191 year 0 months $1.12 \%$

April 1, 20201 year 0 months $\quad 0.37 \%$

April 1, 20211 year 0 months $\quad 0.18 \%$

April 1, 20221 year 0 months $\quad 0.37 \%$

April 1, 20231 year 0 months $\quad 0.37 \%$

April 1, 20241 year 0 months $\quad 0.36 \%$

April 1, 20251 year 0 months $\quad 0.36 \%$

April 1, 20261 year 0 months $\quad 0.36 \%$

April 1, 20271 year 0 months $\quad 0.36 \%$

April 1, 20281 year 0 months $\quad 0.36 \%$

April 1, 20291 year 0 months $\quad 0.18 \%$

April 1, 20301 year 0 months $\quad 0.36 \%$

April 1, 2031 Remaining $\quad 0.32 \%$

\section{Component: Boiler \#1}

Comment: Installed in year 1

\section{Initial Investment}

Initial Cost (base-year \$): $\quad \$ 15,000$

Annual Rate of Increase: $\quad \quad 0 \%$

Expected Asset Life: $\quad 30$ years 0 months

Residual Value Factor: $\quad 50 \%$ 
Cost-Phasing

Cost Adjustment Factor: 0\%

Years/Months (from Date) Date Portion O years 0 months June 1, $2001 \quad 100 \%$

\section{Component: Boiler \#2}

Comment: Installed at end of year two.

\section{Initial Investment}

Initial Cost (base-year \$):

Annual Rate of Increase:

Expected Asset Life: $\quad 32$ years 0 months

Residual Value Factor: $\quad 57 \%$

\section{Cost-Phasing}

Cost Adjustment Factor: 0\%

Years/Months (from Date) Date Portion

2 years 0 months June 1, $2003 \quad 100 \%$

\section{Component: Boiler \#3}

Comment: Installed at end of year 4

\section{Initial Investment}

Initial Cost (base-year \$):

$\$ 15,000$

Annual Rate of Increase:

$0 \%$

Expected Asset Life: $\quad 34$ years 0 months

Residual Value Factor: $\quad 63 \%$

\section{Cost-Phasing}

Cost Adjustment Factor: 0\%

Years/Months (from Date) Date Portion

4 years 0 months June 1, $2005100 \%$ 


\section{Base Case: Existing 60\% Boilers Alternative: Phased Boiler Replacement \\ General Information}

File Name:

Run Date:

Project Name:

Project Location:

Analysis Type:

Analyst:

Comment

Base Date of Study:

Service Date:

Study Period:

Discount Rate:

C:\Program Files \BLCC5\projects\Class Exercise C2.xml

Thu Sep 20 10:44:20 EDT 2001

Class Exercise C2

Maryland

Federal Analysis, Agency-Funded Project

Gene Meyer

Phased Boiler Replacement Versus Base Case of Do Nothing

June 1, 2001

June 1, 2001

15 years 0 months(June 1, 2001 through May 31, 2016)

$3.3 \%$

End-of-Year

Discounting Convention:

\section{Comparison of Present-Value Costs}

\section{PV Life-Cycle Cost}

Base Case Alternative Savings from Alternative

Initial Investment Costs:

Capital Requirements as of Base Date

$\$ 0 \$ 42,231$

$-\$ 42,231$

Future Costs:

$\begin{array}{lrrr}\text { Energy Consumption Costs } & \$ 312,870 & \$ 228,639 & \$ 84,231 \\ \text { Energy Demand Charges } & \$ 0 & \$ 0 & \$ 0 \\ \text { Energy Utility Rebates } & \$ 0 & \$ 0 & \$ 0 \\ \text { Water Costs } & \$ 0 & \$ 0 & \$ 0 \\ \text { Recurring and Non-Recurring OM\&R Costs } & \$ 0 & \$ 0 & \$ 0 \\ \text { Capital Replacements } & \$ 0 & \$ 0 & \$ 0 \\ \text { Residual Value at End of Study Period } & \$ 0 & -\$ 15,670 & \$ 15,670 \\ & ------- & ------- & \$ 99,901 \\ \text { Subtotal (for Future Cost Items) } & \$ 312,870 & \$ 212,969 & --------- \\ & ---------- & ---------- & \$ 57,670\end{array}$




\section{Net Savings from Alternative Compared with Base Case}

PV of Non-Investment Savings $\$ 84,231$

- Increased Total Investment $\$ 26,561$

Net Savings $\$ 57,670$

Savings-to-Investment Ratio (SIR)

$\operatorname{SIR}=3.17$

\section{Adjusted Internal Rate of Return}

$\operatorname{AIRR}=11.56 \%$

\section{Payback Period}

Estimated Years to Payback (from beginning of Service Period)

Simple Payback occurs in year 7

Discounted Payback occurs in year 8

\section{Energy Savings Summary}

\section{Energy Savings Summary (in stated units)}

Units are not the same for each energy type; can't report energy savings.

\section{Energy Savings Summary (in MBtu)}

$\begin{array}{lcccc}\text { Energy } & -----A v e r a g e & \text { Annual } & \text { Consumption----- } & \text { Life-Cycle } \\ \text { Type } & \text { Base Case } & \text { Alternative } & \text { Savings } & \text { Savings }\end{array}$

Distillate Fuel Oil (\#1, \#2) 3,729.1 MBtu 1,792.3 MBtu 1,936.8 MBtu 29,047.7 MBtu

\section{Emissions Reduction Summary}

Energy

Type

Distillate Fuel Oil (\#1, \#2)

$$
\begin{aligned}
& \mathrm{CO} 2 \\
& \mathrm{SO} 2
\end{aligned}
$$

NOx

Total:

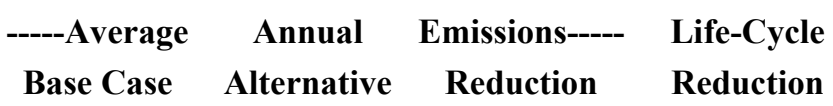

Base Case Alternative Reduction Reduction

$$
1,935.98 \mathrm{~kg} \quad 930.49 \mathrm{~kg} \quad 1,005.49 \mathrm{~kg} \quad 15,080.33 \mathrm{~kg}
$$$$
243.96 \mathrm{~kg} \quad 117.26 \mathrm{~kg} \quad 126.71 \mathrm{~kg} \quad 1,900.37 \mathrm{~kg}
$$

$\mathrm{CO2}$

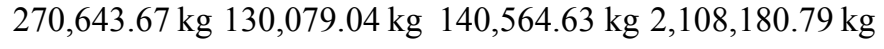

$\mathrm{SO} 2$

$1,935.98 \mathrm{~kg}$

$930.49 \mathrm{~kg}$

$1,005.49 \mathrm{~kg}$

$15,080.33 \mathrm{~kg}$

NOx

$243.96 \mathrm{~kg}$

$117.26 \mathrm{~kg}$

$126.71 \mathrm{~kg}$

$1,900.37 \mathrm{~kg}$ 



\section{Module D}

Replacement of Functional Systems to Improve Energy Efficiency

Objectives: Upon completion of this module, you will understand

- cost-effectiveness requirements for

- new systems or mandatory replacement of functional systems

- optional replacement of functional systems.

- timing of optional system replacement.

- sensitivity analysis. 


\section{Optional Replacement to Increase Energy Efficiency}

- Entire investment cost must be justified, not just incremental cost.

- Timing of optional replacement is independent of remaining system life.

- Optimal timing is affected by changes in energy prices, technology, and other factors. 


\section{Exercise D1}

\section{Economic Evaluation of Air Conditioning System}

\section{PROBLEM STATEMENT}

The existing facility, an 8100 sq. ft. government office building in Virginia, provides administrative space, counseling rooms, and records and research areas. Over time, the increased use of devices such as individual work stations and printers has increased the cooling requirements at the building. The building is currently cooled by several window air conditioners, which require frequent maintenance and consume excessive amounts of energy. On very hot days there are complaints about uncomfortably high temperatures in the building. The building is heated by electric baseboard heating.

\section{Options}

\section{Maintain Existing System}

With the current maintenance schedule, the present heating and cooling system could be kept functional for another 20 years.

\section{Install DX Split System}

Install new "split-system" air-conditioning unit and associated elements required to provide adequate space conditioning. The installation will provide a new air distribution system for the building, with central air conditioning throughout.

\section{Connect to Central Chilled Water Plant}

Install piping network to connect the office building to the central chilled water plant on the site. The installation will provide a new air distribution system for the building, with air conditioning throughout. This option, if cost-effective, would be preferred to the DX Split System because it would allow centralized maintenance. A general overhaul of the Central Plant is scheduled for 2004. If the piping connection to the office building were done then, the initial investment cost would be reduced by about $15 \%$.

Electric baseboard heating will continue to be used for the facility. The removed air conditioning units will not have any appreciable salvage value. Either upgrade will require a planning and installation period of one year. The equipment installation will inconvenience personnel in the office building but should not shut the office down 


\section{Exercise D1 (cont.)}

\section{ANALYSIS}

Perform an LCC analysis to determine which of the available options results in the lowest life-cycle cost. Perform sensitivity analysis for those of the uncertain variables that have the greatest impact on LCC, in this case initial investment cost and electricity prices.

\section{Scenarios}

1. Analyze the outcomes, assuming that

a) you will keep the existing system if its LCC is lower than the LCCs of the alternatives, or

b) you have already decided to replace the existing system with one of the possible two alternatives.

2. Perform sensitivity analysis by varying initial investment costs and electricity prices.

a) Determine critical inputs by changing all input values by $10 \%$ and calculating the percentage effect on LCC.

b) Calculate NS for all alternatives by changing energy prices and investment costs by $\pm 10 \%$, $\pm 25 \%$, and $\pm 50 \%$. 


\section{General Project Information}

- AC system in NAVFAC office building in Virginia

- Discount rate: $\mathbf{3 . 3 \%}$

- Mid-year discounting

- Constant-dollar analysis

- Agency-funded project 


\section{Key dates}

- Base Date:

- Study period:

- Implementation Period:

- Service Date:
June 2001

21 years

1 year

June 2002 


\section{Base Case: Keep Existing System}

Initial cost: $\quad \$ 0$

Energy consumption: $\quad 290,000 \mathrm{kWh} / \mathrm{yr}$

Energy price: $\quad \mathbf{\$ 0 . 0 8 7 1 1 / k W h}$, industrial

Ann.-recurr. OM\&R costs: \$1,050, increasing at 2\%/yr

Non-ann.rec. $O M \& R$ costs: $\$ \mathbf{5 , 0 0 0}$ in 3 -year intervals through year 18

Expected system life: $\quad 20$ years 


\section{Alternative I: DX Split System AC}

Initial cost:

Energy consumption:

Energy price:
$\$ 210,000$

$120,330 \mathrm{kWh} / \mathrm{yr}$

$\$ \mathbf{0 . 0 8 7 1 1 / k W h}$, industrial

Ann.-recurr. OM\&R costs: $\$ 530$

Non-ann.rec. $O M \& R$ costs: $\$ 6,300$ in yrs. $5,10,15$

Capital replacement cost: $\$ 331,130$ in year 15

Useful Life: 15 years

Residual Value Factor: 67\%

Expected system life: $\quad 20$ years 


\section{Alternative II: Central Plant Connection}

Initial cost:

Energy consumption:

Energy price:
$\$ 265,000$

$112,000 \mathrm{kWh} / \mathrm{yr}$

$\$ 0.08711 / \mathrm{kWh}$, industrial

Ann.-recurr. OM\&R costs: $\$ 126$

Non-ann.rec. OM\&R costs: \$950 in yrs 3, 9, 15, 18

Expected system life: $\quad 20$ years 


\section{Split System - Cash Flow Diagram}

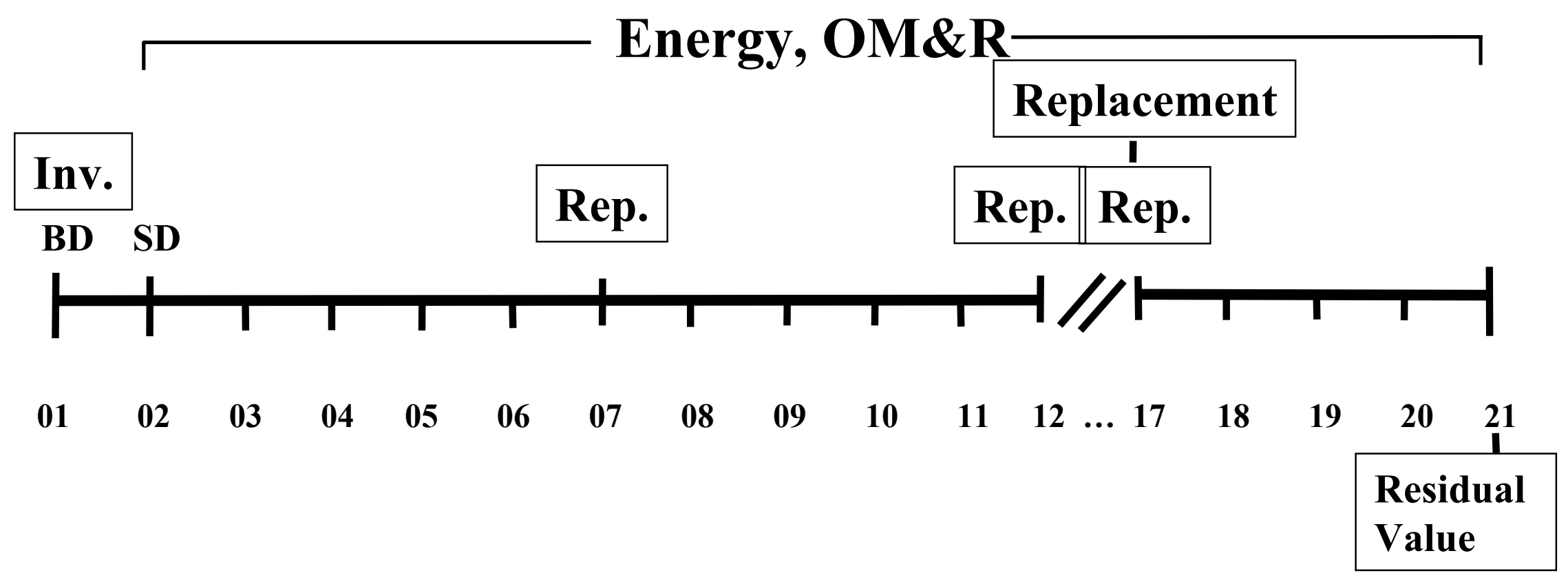




\section{Key Dates}

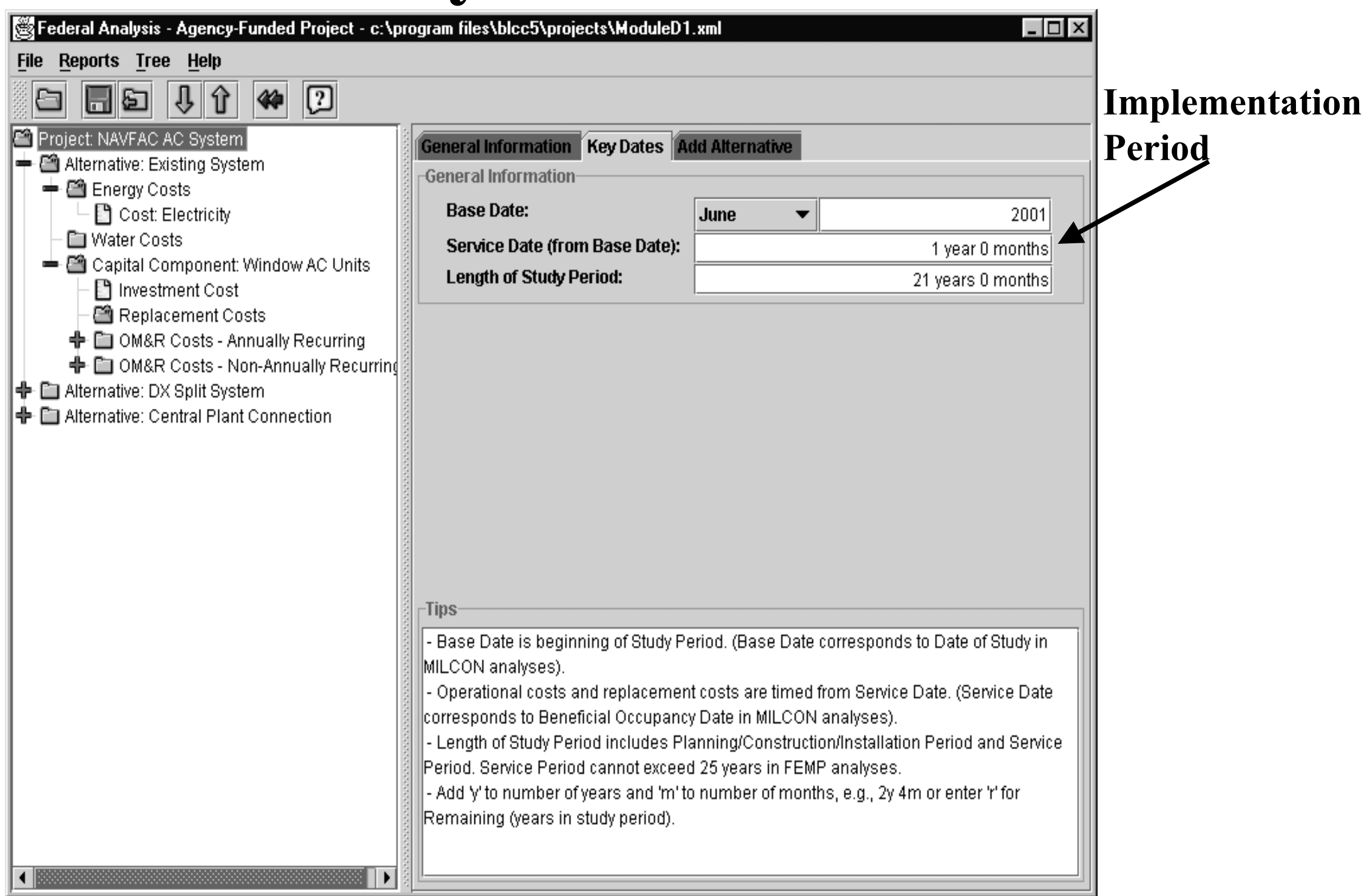




\section{Energy Costs}

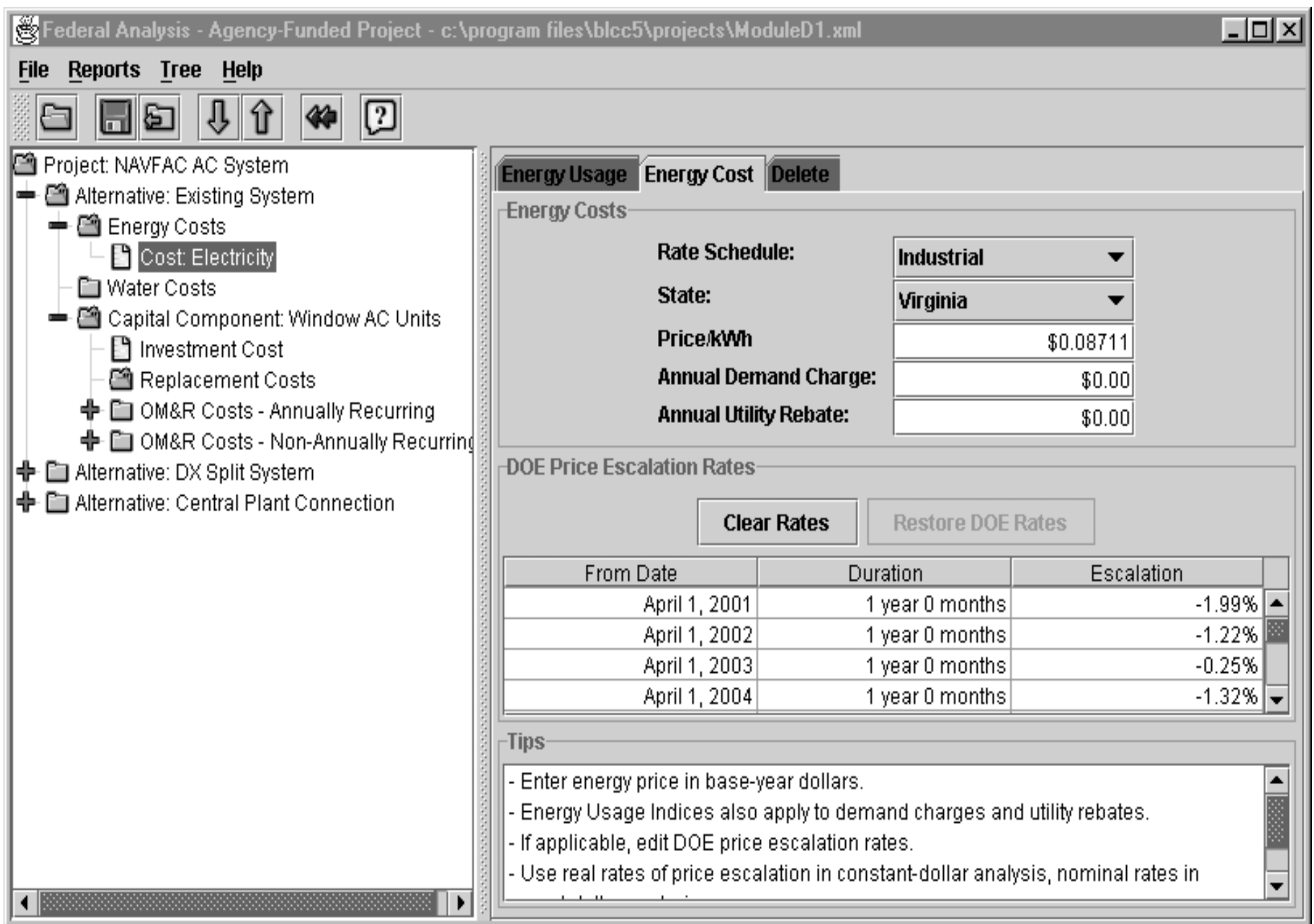




\section{Investment Costs}

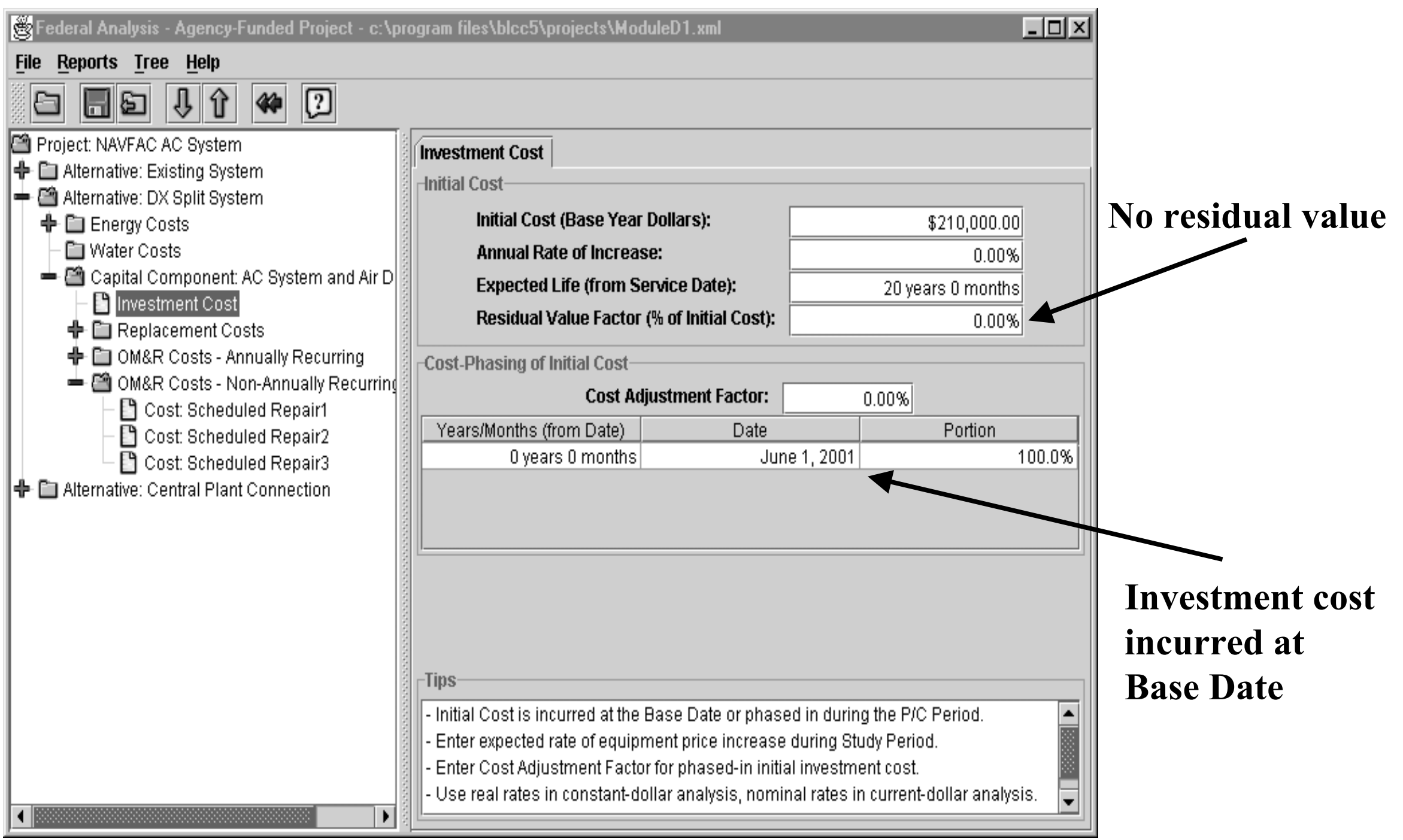




\section{OM\&R Costs}

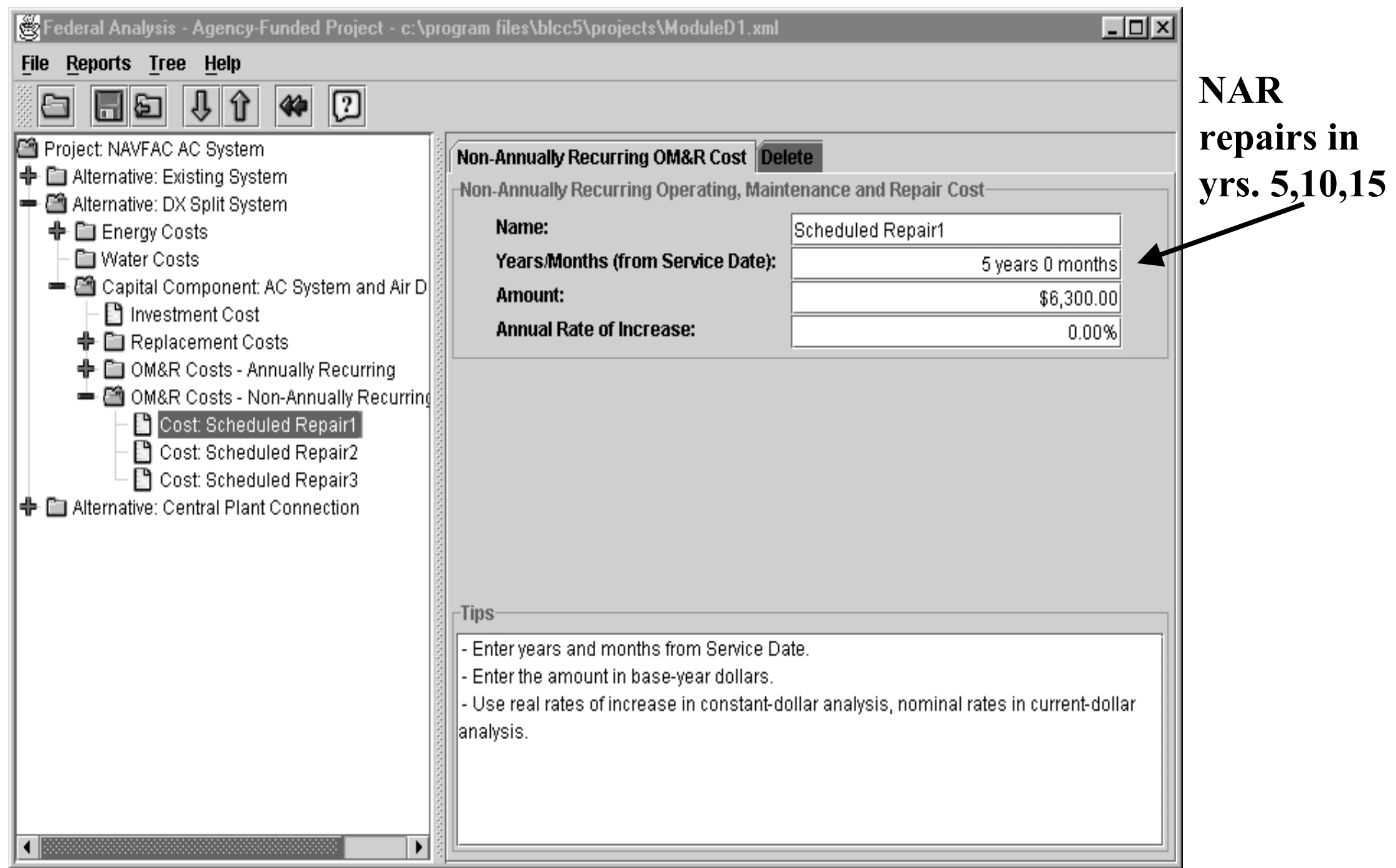




\section{NIST BLCC 5.0-01: Lowest LCC}

Consistent with Federal Life Cycle Cost Methodology and Procedures, 10 CFR, Part 436, Subpart A

\section{General Information}

File Name:

c: \program files\blcc5\projects\ModuleDl.xml

Run Date:

Thu fug 02 16:20:54 EDT 2001

Analysis Type:

Federal Analysis, Agency-Funded Project

Project Name:

NAVFAC AC system

Project Location:

Virginia

Analyst:

SKF

Comment:

Provide economical and effective air conditioning for the family housing office at

Base Date:

the Dahlgren, VA Naval station.

Service Date:

June 1,2001

Study Period:

21 years 0 months (June 1, 2001 through May 31, 2022)

Discount Rate:

Discounting

Convention:

Lowest LCC

Mid-Year

\section{Lowest LCC} Existing System

Comparative Present-Value Costs of Alternatives

(Shown in Ascending Order of Initial Cost, * = Lowest LCC)

Alternative

Initial Cost (PV) Life Cycle Cost (PV)

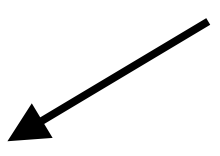

Existing System

$\$ 0$

$\$ 372,359$ *

DX Split System

$\$ 210,000$

$\$ 377,070$

Central Plant Connection

$\$ 265,000$

$\$ 398,039$ 


\section{Existing System and DX SS}

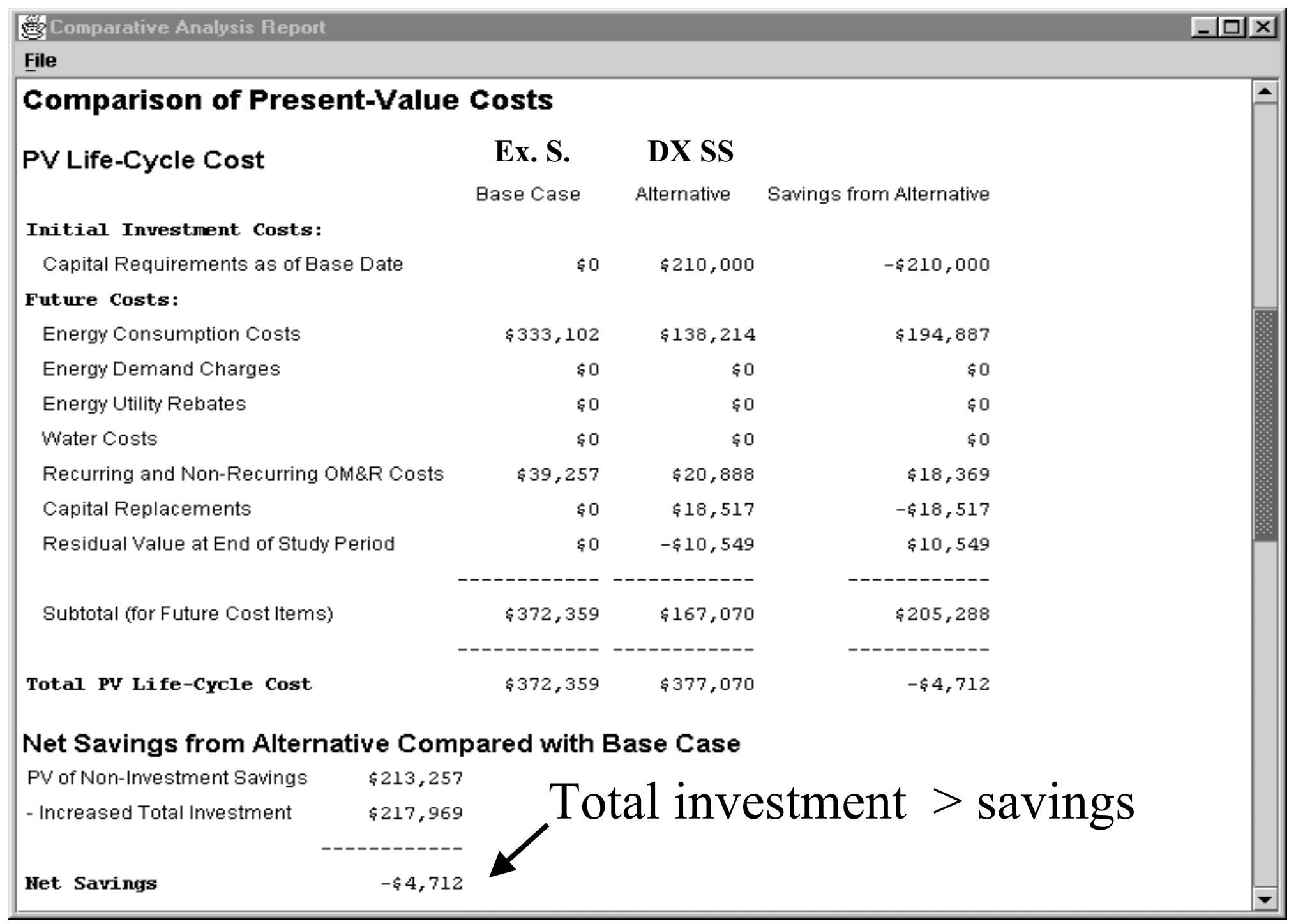




\section{Existing System and CP Conn.}

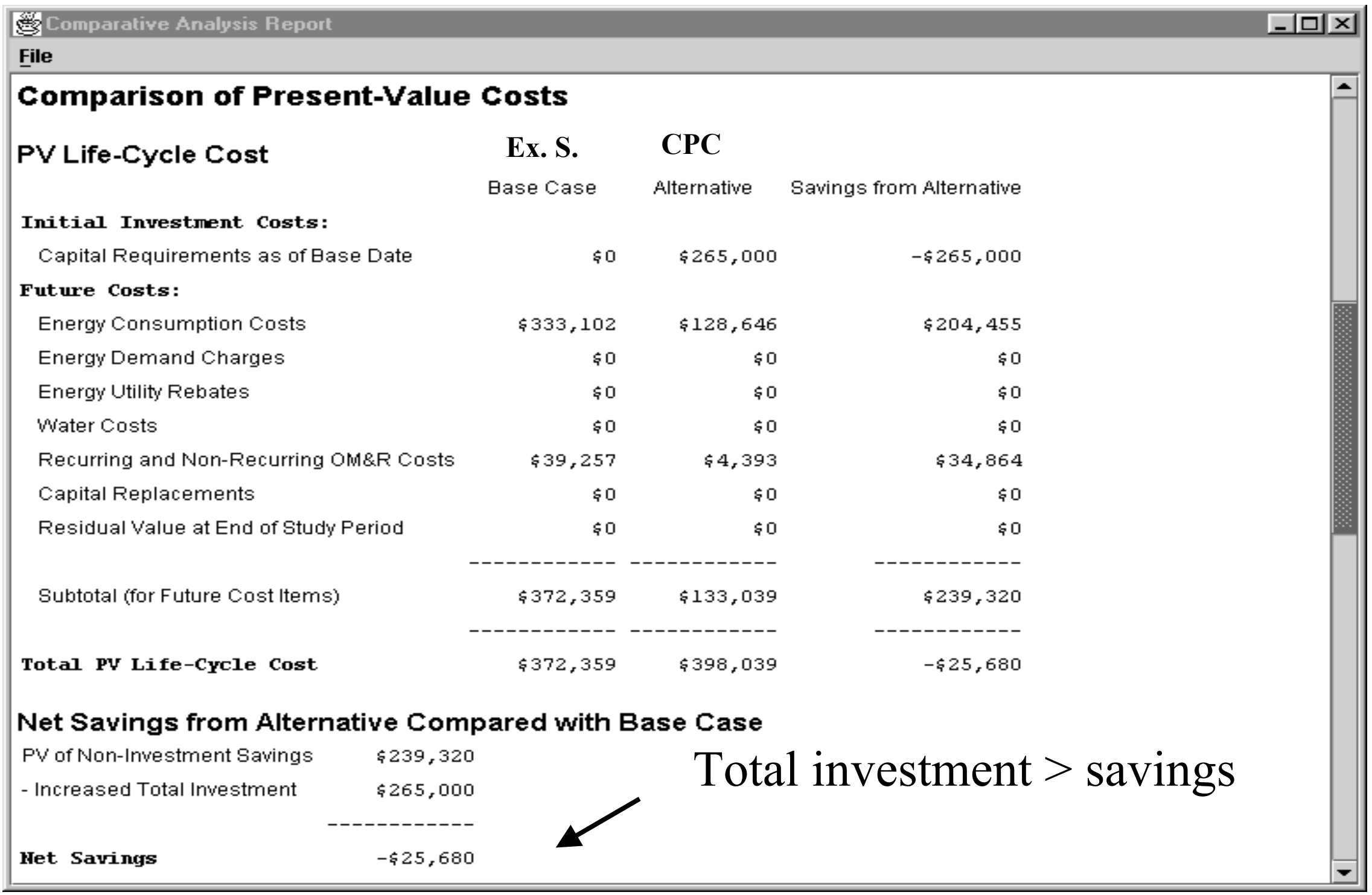




\section{LCCs - Optional Replacement}

For optional replacement of a functional system, entire investment cost must be supported by savings.

Investment Base Case Costs Savings from Upgrades Replacement costs Ex. System Residual Value Total Inv. Costs PV energy costs $\$ \mathbf{\$ 3 3 3 , 1 0 2}$ PV OM\&R costs Total Operat'l Costs Net Savings 0

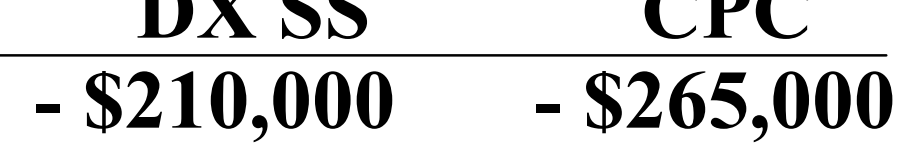

$-18,517$

\begin{tabular}{lr} 
& \multicolumn{1}{c}{-} \\
\hline & \\
& $\$ 333,102$ \\
39,257
\end{tabular}
10,549 $-\$ 217,969 \quad-\$ 265,000$ 194,887 204,456 39,257 18,369 $\$ 213,257$ 34,864 $\$ 239,320$ $-\$ 25,680$ 


\section{Split System and Central Plant Conn.}

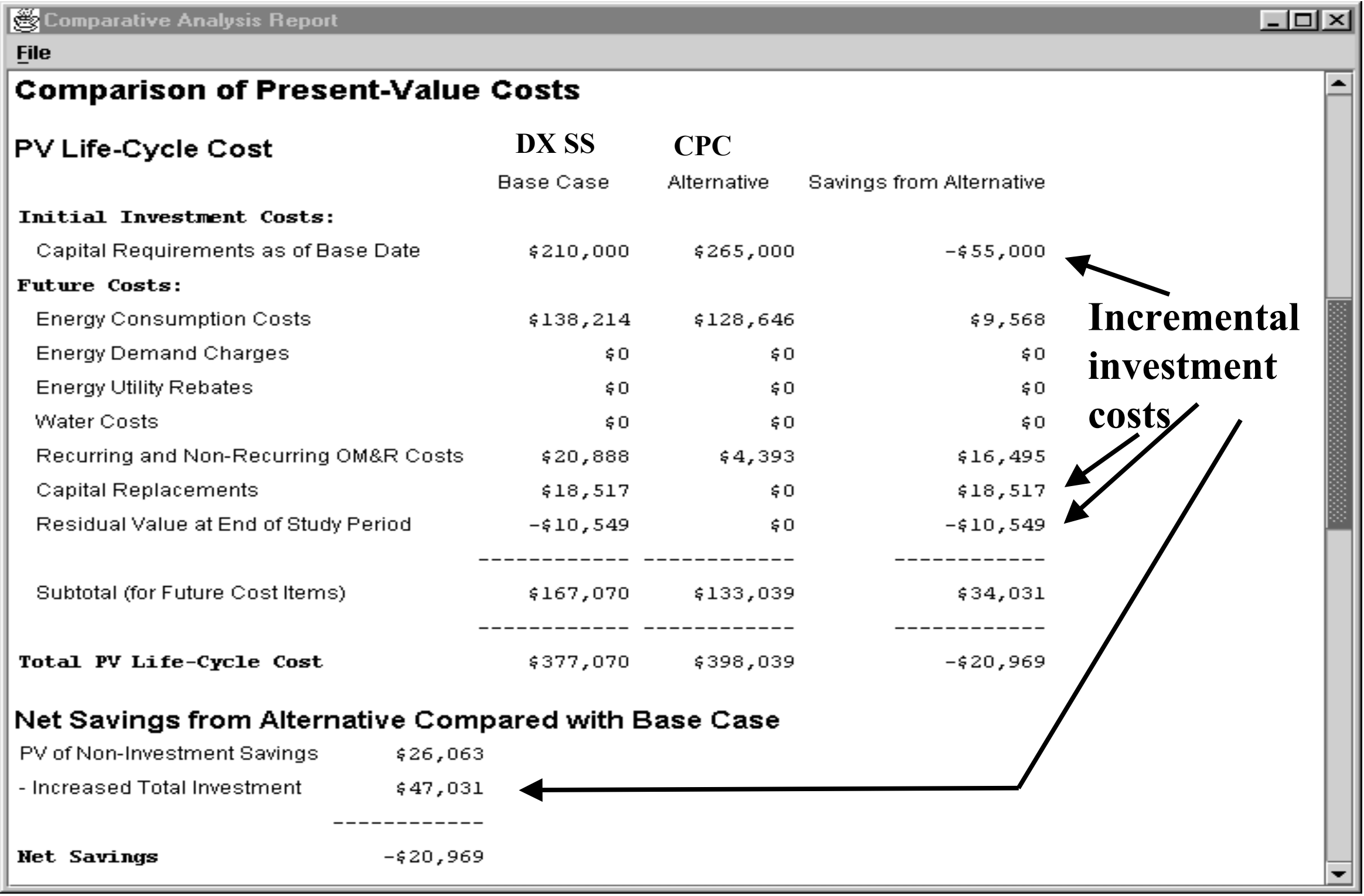




\section{LCCs - Mandatory Replacement}

For new system or mandatory replacement of an existing system, incremental investment cost must be supported by savings.

Investment

Replacement costs

Residual Value

Total Inv. Costs

PV energy costs

PV OM\&R costs
Total Operat'l Costs

Net Savings
Costs

\begin{tabular}{rcr}
\multicolumn{1}{c}{ DX SS } & CPC & from alternative \\
\hline $\mathbf{2 1 0 , 0 0 0}$ & $\mathbf{\$ 2 6 5 , 0 0 0}$ & $\mathbf{- \$ 5 5 , 0 0 0}$ \\
$\mathbf{1 8 , 5 1 7}$ & - & $\mathbf{1 8 , 5 1 7}$ \\
$-\mathbf{1 0 , 5 4 9}$ & - & $-\mathbf{1 0 , 5 4 9}$ \\
\hline $\mathbf{2 1 7 , 9 6 8}$ & $\mathbf{\$ 2 6 5 , 0 0 0}$ & $\mathbf{\$ 4 7 , 0 3 2}$ \\
$\mathbf{1 3 8 , 2 1 4}$ & $\mathbf{1 3 4 , 1 4 1}$ & $\mathbf{9 , 5 6 8}$ \\
$\mathbf{2 0 , 8 8 8}$ & $\mathbf{4 , 3 9 3}$ & $\mathbf{1 6 , 4 9 5}$ \\
\hline $\mathbf{\$ 1 5 9 , 1 0 2}$ & $\mathbf{\$ 1 3 8 , 5 3 4}$ & $\mathbf{\$} \mathbf{2 6 , 0 6 3}$ \\
- & & $-\mathbf{\$ 2 0 , 9 6 9}$
\end{tabular}




\section{LCCs of AC Systems (cont.)}

Analysis results:

- If replacement is optional, Existing System has lowest LCC.

- If replacement is mandatory, DX Split System has lowest LCC.

- Central Plant Connection is not cost-effective in either case.

Other considerations:

- Outcome may be changed by

- Change in energy prices, investment or OM\&R costs.

- Change in heating and cooling requirements, timing, and other factors.

Evaluate other option:

- Postpone Central Plant Connection. 


\section{Sensitivity Analysis}

Repeat economic evaluation with one or more input values changed.

- Determine

- which input values are uncertain.

- which input values are critical.

- Evaluate

- effect of changes on LCC, NS, or any other measure of economic evaluation. 


\section{Sensitivity Analysis (cont.)}

Identify critical inputs for DX Split System

Uncertain Input

Energy price/kWh $\quad \$ \mathbf{\$ 0 . 0 9 5 8}$

Investment cost

$A R O M \& R$ cost

NAR OM\&R cost
$10 \%$ Increase

231,000

583

6,930
Change in LCC in \$ in $\%$
$\$ 13,788 \quad 3.7 \%$ *

$21,000 \quad 5.6 \%$ *

$755 \quad 0.2 \%$

$1,334 \quad 0.4 \%$

*Input values with highest impact on LCC. 


\section{Sensitivity Analysis (cont.)}

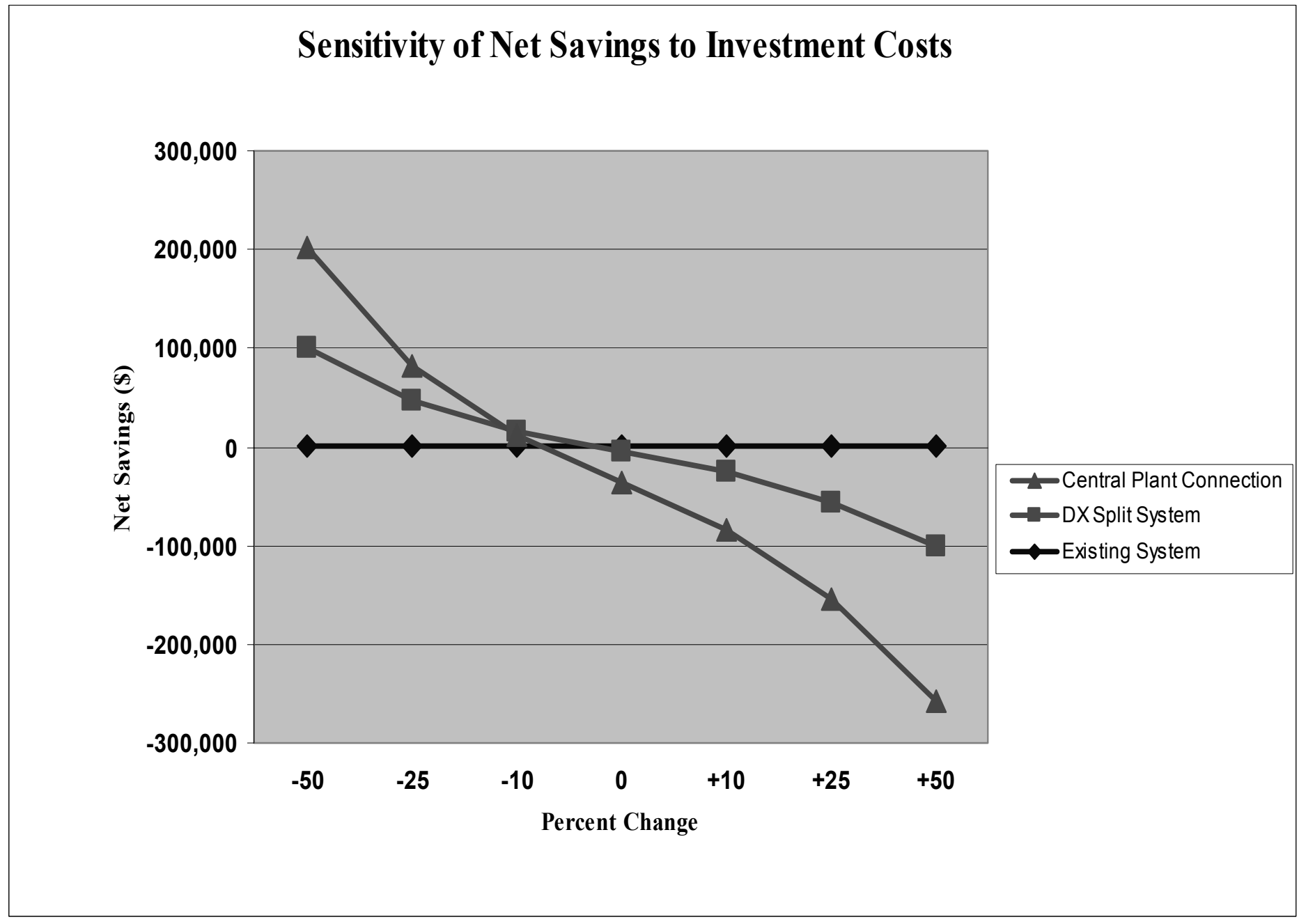




\section{Sensitivity Analysis (cont.)}

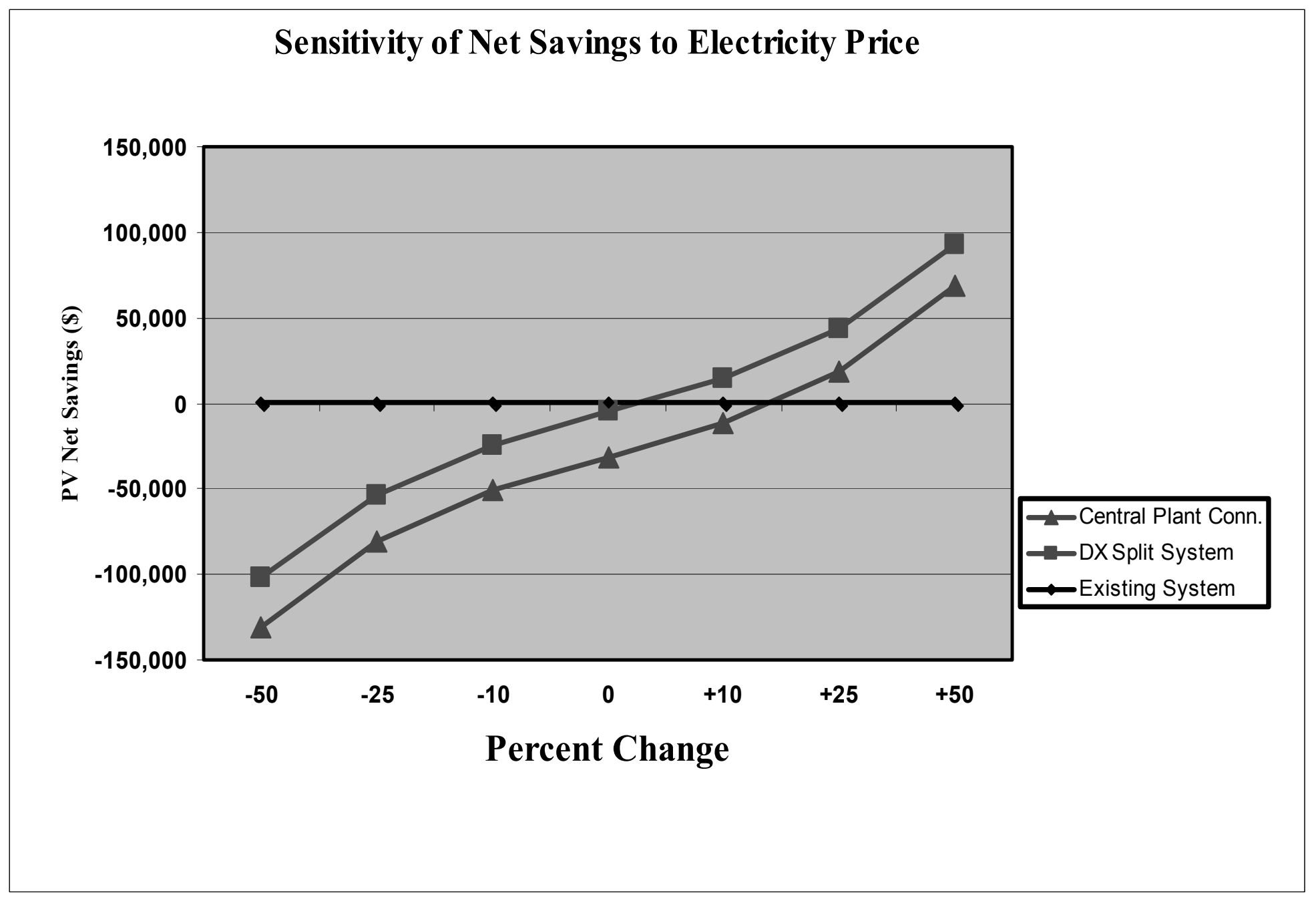




\section{Postponed Central Plant Connection}

Postpone CP Connection by three years

- Use cost phasing of initial investment cost.

- Use residual value factor of $\mathbf{1 5 \%}$.

- Use indexing to postpone energy and OM\&R costs.

- Include energy costs and OM\&R costs of the existing system for the three-year delay.

Perform Sensitivity Analysis

- Increase electricity costs for DX Split System by $35 \%$. 


\section{PP CP Conn. - Cash Flow Diagram}

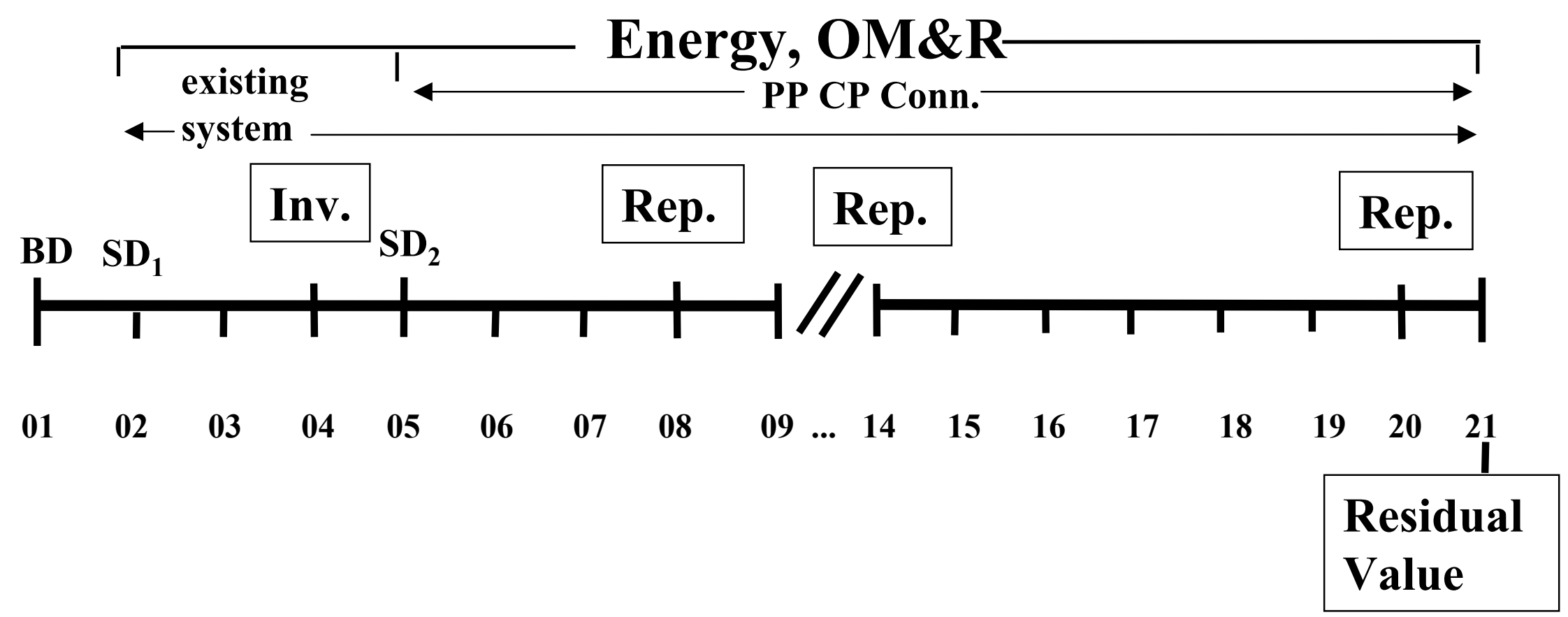




\section{Cost Phasing of Initial Investment}

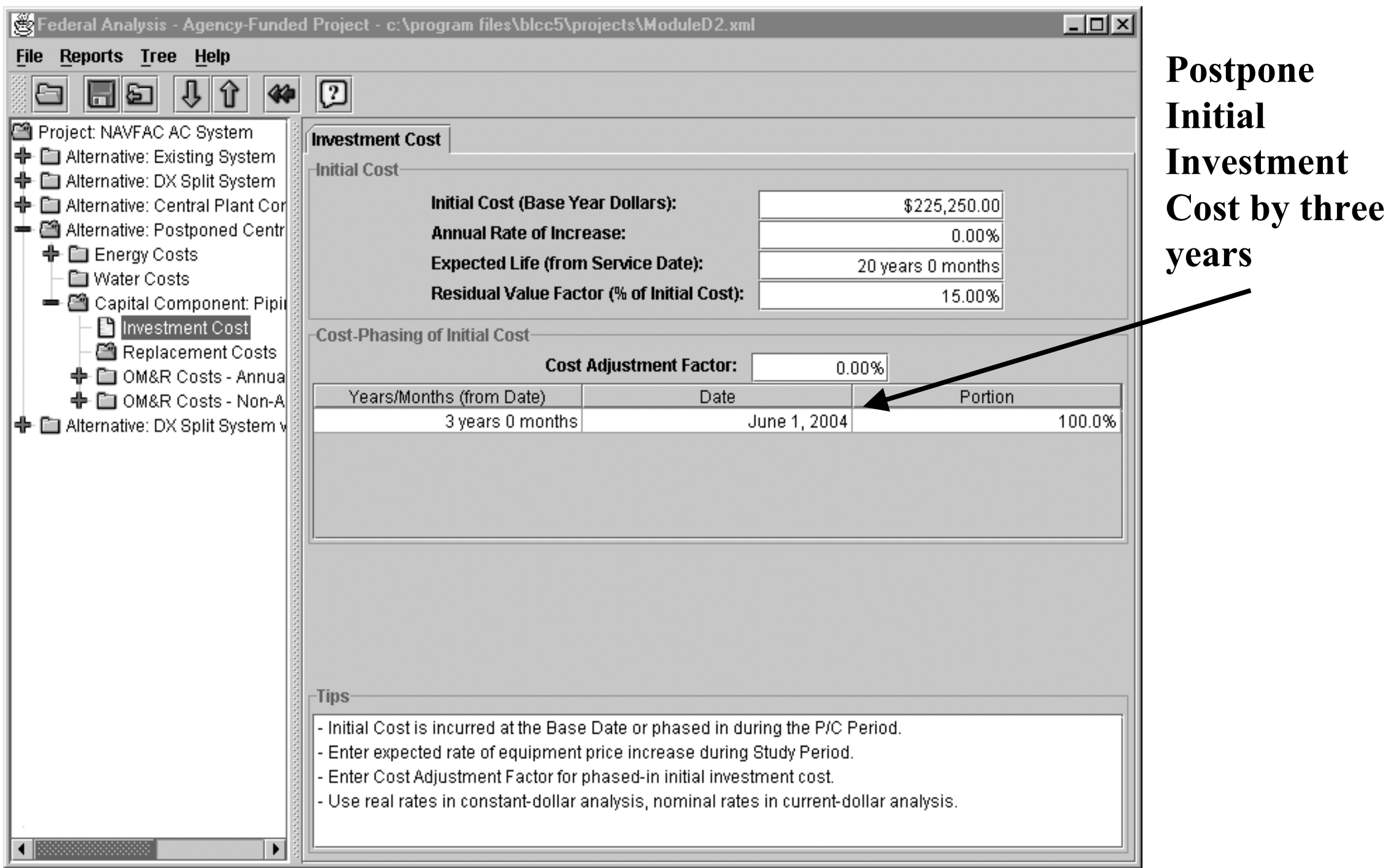




\section{Indexing of Energy Usage}

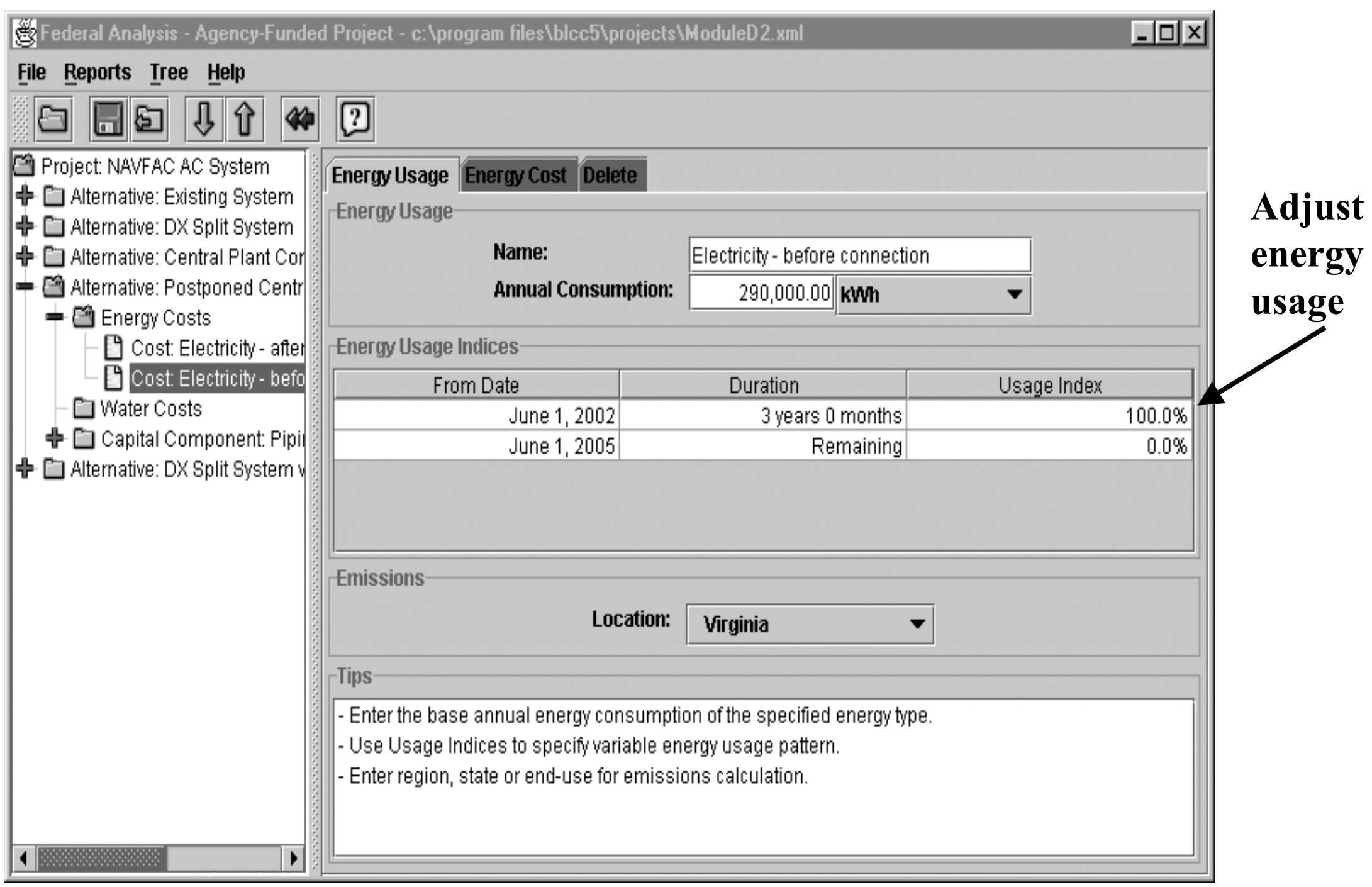




\section{Indexing of OM\&R Costs}

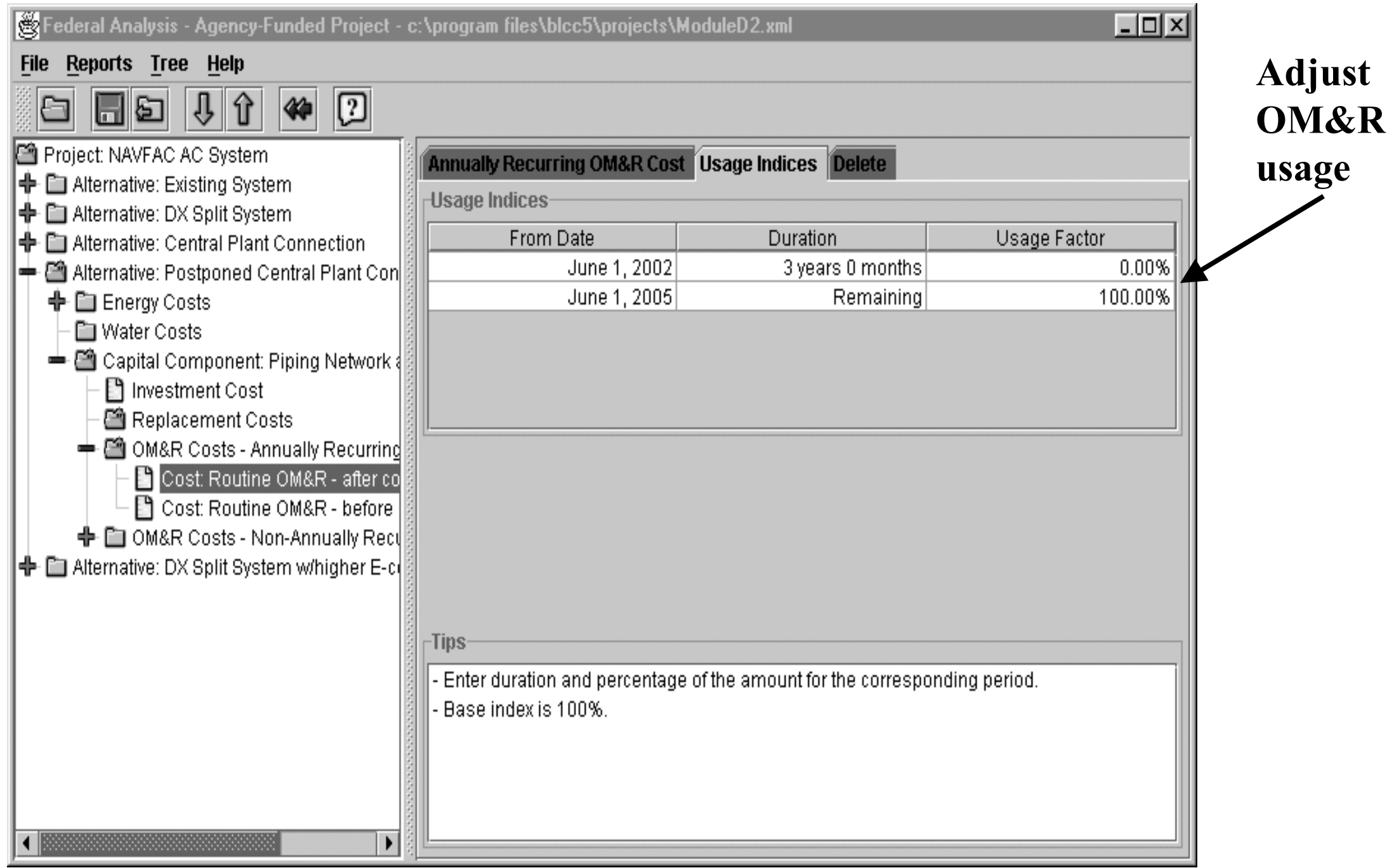




\section{Lowest LCC Report}

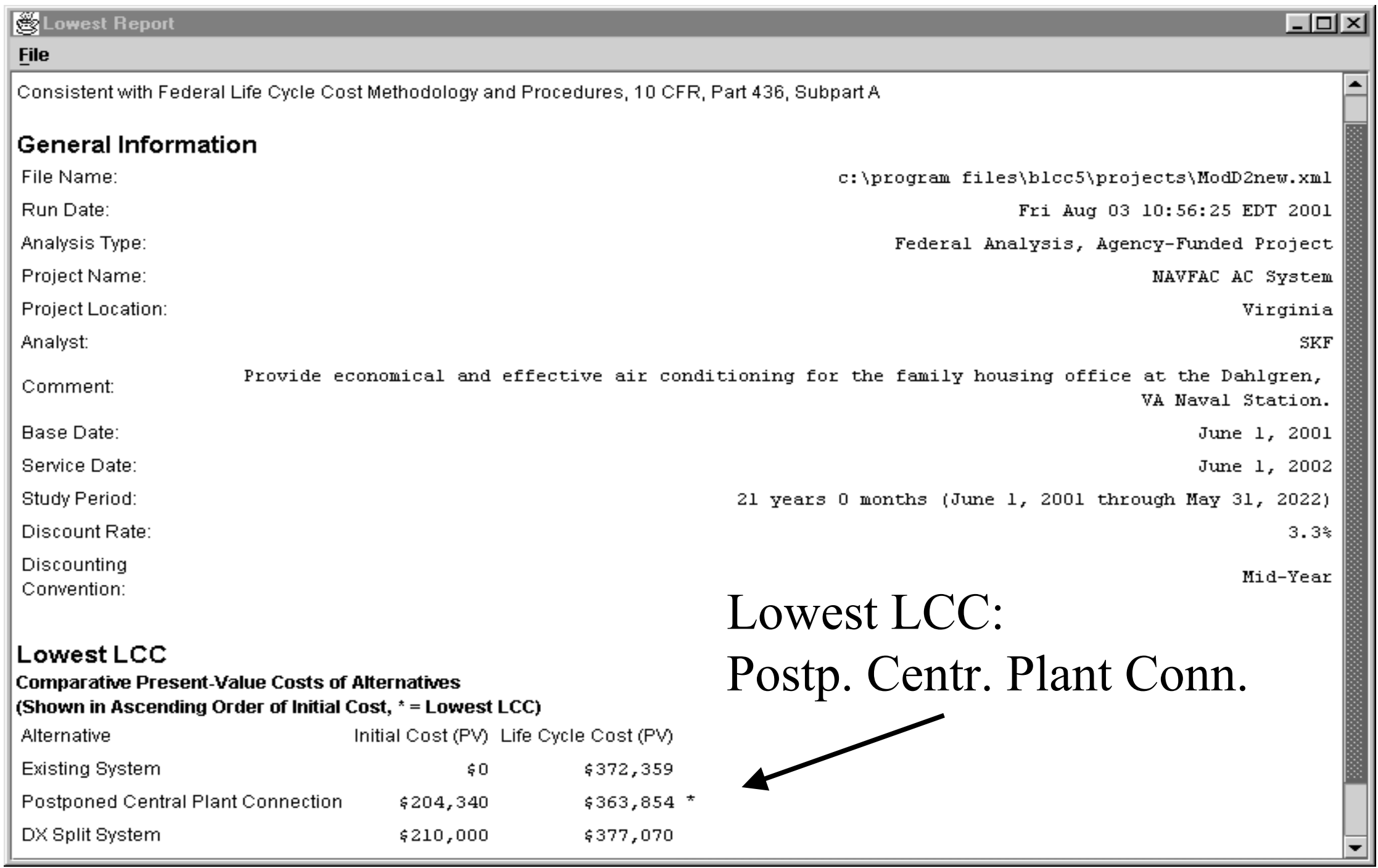




\section{SS and Postponed CP Conn.}

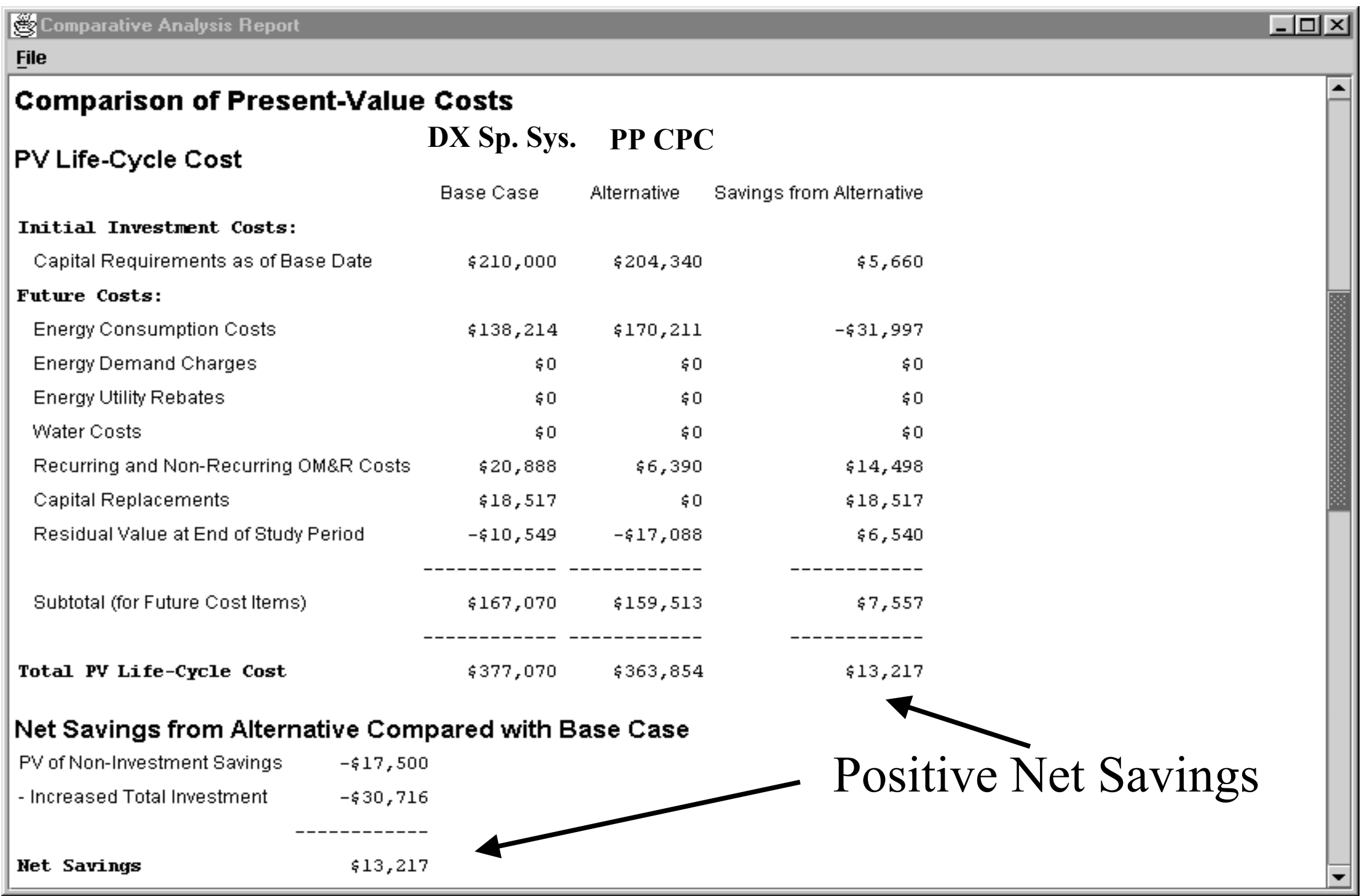




\section{Hi-E SS and Imm. CP Conn.}

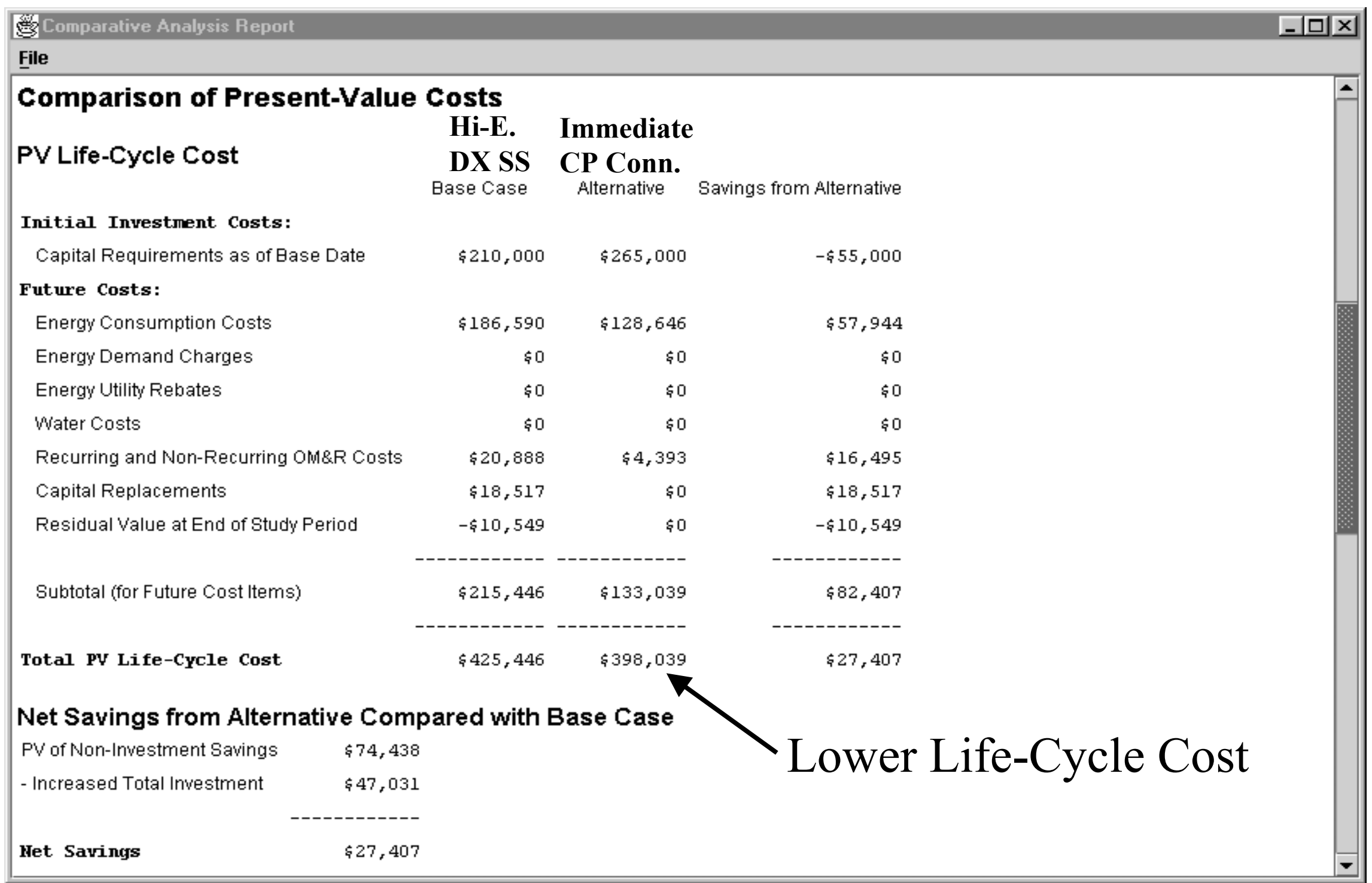




\section{Summary of LCC Results}

DX SS $\quad$ CP $\quad$ PPCP Hi-E DX SS

Investment cost

Replacement costs

Residual value

Energy costs

OM\&R costs

Total PV LCC
$\$ 210,000 \quad \$ 265,000 \quad \$ 204,340 \quad \$ 210,000$

$\begin{array}{llllll}\$ 18,517 & \$ & 0 & \$ & \$ 18,517\end{array}$

$\begin{array}{lllllll}-\$ 10,549 & \$ & 0 & -\$ 17,088 & -\$ 10,549\end{array}$

$\mathbf{\$ 1 3 8 , 2 1 4} \$ \mathbf{\$ 1 2 8 , 6 4 6} \mathbf{\$ 1 7 0 , 2 1 1} \mathbf{\$ 1 8 6 , 5 9 0}$

$\begin{array}{lllllll}\$ 20,888 & \$ & 4,393 & \$ & 6,099 & \$ 20,888\end{array}$

$\$ \mathbf{\$ 3 7 7 , 0 7 0} \$ \mathbf{\$ 3 9 8 , 0 3 9} \quad \$ 363,563 \quad \$ 425,446$ 


\section{Comparison of LCC Costs}

\section{Life-Cycle Costs of AC System Alternatives}

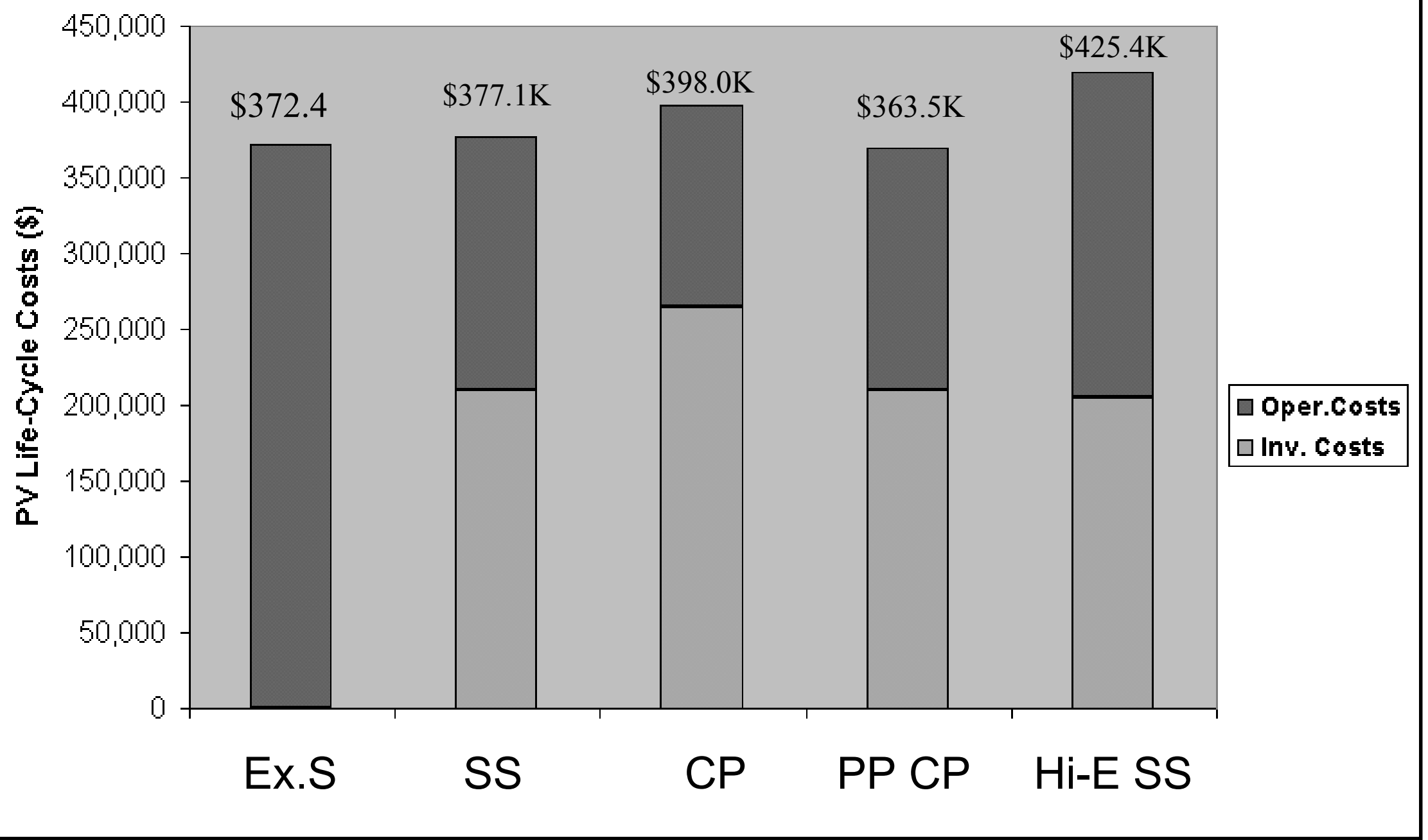




\section{Summary of Analysis Results}

- Cost-effectiveness selection depends on circumstances and timing.

- Other considerations:

- Postponed CP Connection has higher life-cycle energy consumption and emissions than immediate installation of DX Split System.

- LCC for postponed CP Connection does not include productivity losses for period of delay.

- Conclusion:

- Lowest LCC is one among many criteria that affect decision making. 


\section{Class Exercise D2}

\section{Economic Evaluation of Air Conditioning System}

Refer to the problem statement in Module D. Add Alternative 3 to BLCC5 project file Exercise D1.xml.

\section{Alternative 3: Postponed Central Plant Connection}

Assume that to avoid the expected decline in staff productivity during the summer months, management has decided to upgrade to the DX Split System or the Central Plant Connection regardless of whether the existing system is costeffective or not. Determine whether the Central Plant Connection would be cost-effective if postponed by three years to coincide with the planned general overhaul of the Central Plant.

-Use the same inputs as above for Central Plant Connection, except for investment costs, which would be lower by 15 $\%$.

-Postpone Service Date by three years.

-Use cost-phasing feature in BLCC5 to enter initial investment cost with a $0 \%$ rate of increase.

-Enter residual value factor for a period of three years $(3 / 20$ years $=15 \%)$.

-Use indexing feature to postpone occurrence of energy and OM\&R costs.

-Include in analysis energy costs and OM\&R costs of the existing system for the three-year delay.

\section{Perform Sensitivity Analysis}

\section{Alternative 4: - DX Split System with High Energy Consumption}

Consider there is uncertainty about the energy consumption of the DX Split System and that annual utility costs could be higher by $35 \%$. Determine how this scenario would change the selection of the most cost-effective alternative. 


\section{Solution to Class Exercise D2}

\section{NIST BLCC 5.0-01: Input Data Listing}

Consistent with Federal Life Cycle Cost Methodology and Procedures, 10 CFR, Part 436, Subpart A

\section{General Information}

File Name:

Run Date:

Analysis Type:

Project Name:

Project Location:

Analyst:

Comment:

Base Date:

Service Date:

Study Period:

Discount Rate:

Discounting

Convention:
C:\Program Files \BLCC5 \projects \Class Exercise D2.xml

Thu Sep 20 11:07:37 EDT 2001

Federal Analysis, Agency-Funded Project

Class Exercise D2

Virginia

SKF

Provide economical and effective air conditioning for the family housing office at the Dahlgren,

VA Naval Station.

June 1, 2001

June 1, 2002

21 years 0 months (June 1, 2001 through May 31, 2022)

Mid-Year

Discount and Escalation Rates are REAL (exclusive of general inflation)

\section{Alternative: Existing System}

Comment: Functional for 20 years with current maintenance and repair schedule

\section{Energy: Electricity}

$\begin{array}{lr}\text { Annual Consumption: } & 290,000.0 \mathrm{kWh} \\ \text { Price per Unit: } & \$ 0.08711 \\ \text { Demand Charge: } & \$ 0 \\ \text { Utility Rebate: } & \$ 0 \\ \text { Location: } & \text { Virginia } \\ \text { Rate Schedule: } & \text { Industrial } \\ \text { State: } & \text { Virginia }\end{array}$

\section{Usage Indices}

From Date Duration Usage Index

June 1, 2002 Remaining 100\%

\section{Escalation Rates}

From Date Duration Escalation

April 1, 20011 year 0 months $\quad-1.99 \%$

April 1, 20021 year 0 months $\quad-1.22 \%$

April 1, 20031 year 0 months $\quad-0.25 \%$

April 1, 20041 year 0 months $\quad-1.32 \%$

April 1, 20051 year 0 months $\quad-1.09 \%$

April 1, 20061 year 0 months $\quad-1.52 \%$

April 1, 20071 year 0 months $\quad-1.2 \%$ 
April 1, 20081 year 0 months

April 1, 20091 year 0 months

April 1, 20101 year 0 months

April 1, 20111 year 0 months

April 1, 20121 year 0 months

April 1, 20131 year 0 months

April 1, 20141 year 0 months

April 1, 20151 year 0 months

April 1, 20161 year 0 months

April 1, 20171 year 0 months

April 1, 20181 year 0 months

April 1, 20191 year 0 months

April 1, 20201 year 0 months

April 1, 20211 year 0 months

April 1, 20221 year 0 months

April 1, 20231 year 0 months

April 1, 20241 year 0 months

April 1, 20251 year 0 months

April 1, 20261 year 0 months

April 1, 20271 year 0 months

April 1, 20281 year 0 months

April 1, 20291 year 0 months

April 1, 20301 year 0 months

April 1, 2031 Remaining
$-0.87 \%$
$-0.35 \%$
$-0.79 \%$
$-0.8 \%$
$-0.27 \%$
$0.36 \%$
$0.36 \%$
$0.62 \%$
$0.79 \%$
$0.79 \%$
$0.43 \%$
$0.61 \%$
$0.26 \%$
$0.26 \%$
$0.26 \%$
$0.17 \%$
$0.26 \%$
$0.25 \%$
$0.17 \%$
$0.25 \%$
$0.25 \%$
$0.25 \%$
$0.17 \%$
$0.22 \%$

\section{Component: Window AC Units}

\section{Initial Investment}

Initial Cost (base-year \$): $\quad \$ 0$

Annual Rate of Increase: $\quad \quad 0 \%$

Expected Asset Life: $\quad 20$ years 0 months

Residual Value Factor: $\quad 0 \%$

\section{Cost-Phasing}

Cost Adjustment Factor: 0\%

Years/Months (from Date) Date Portion 0 years 0 months $\quad$ June 1, $2001 \quad 100 \%$

\section{Recurring OM\&R: Routine OM\&R}

Amount: $\quad \$ 1,050$

Annual Rate of Increase: $\quad 2.0 \%$

Usage Indices

From Date Duration Factor

June 1, 2002 Remaining 100\%

Non-Recurring OM\&R: Major Repair1

Years/Months: $\quad 3$ years 0 months

Amount: $\quad \$ 5,000$ 
Non-Recurring OM\&R: Major Repair2

Years/Months: 6 years 0 months

Amount: $\quad \$ 5,000$

Annual Rate of Increase: $\quad 0 \%$

Non-Recurring OM\&R: Major Repair3

Years/Months: $\quad 9$ years 0 months

Amount: $\quad \$ 5,000$

Annual Rate of Increase: $\quad 0 \%$

Non-Recurring OM\&R: Major Repair4

Years/Months: $\quad 12$ years 0 months

Amount: $\quad \$ 5,000$

Annual Rate of Increase: $\quad 0 \%$

Non-Recurring OM\&R: Major Repair5

Years/Months: $\quad 15$ years 0 months

Amount: $\quad \$ 5,000$

Annual Rate of Increase: $\quad 0 \%$

Non-Recurring OM\&R: Major Repair6

Years/Months: $\quad 18$ years 0 months

Amount: $\quad \$ 5,000$

Annual Rate of Increase: $\quad 0 \%$

\section{Alternative: DX Split System}

Comment: Install split-system central AC unit, with new air distribution system

\section{Energy: Electricity}

Annual Consumption: $120,330.0 \mathrm{kWh}$

Price per Unit: $\quad \$ 0.08711$

Demand Charge: $\quad \$ 0$

Utility Rebate: $\quad \$ 0$

Location: Virginia

Rate Schedule: Industrial

State: Virginia

\section{Usage Indices}

From Date Duration Usage Index

June 1, 2002 Remaining 100\%

Escalation Rates

From Date Duration Escalation

April 1, 20011 year 0 months $\quad-1.99 \%$

April 1, 20021 year 0 months $\quad-1.22 \%$

April 1, 20031 year 0 months $\quad-0.25 \%$

April 1, 20041 year 0 months $\quad-1.32 \%$ 
April 1, 20051 year 0 months

April 1, 20061 year 0 months

April 1, 20071 year 0 months

April 1, 20081 year 0 months

April 1, 20091 year 0 months

April 1, 20101 year 0 months

April 1, 20111 year 0 months

April 1, 20121 year 0 months

April 1, 20131 year 0 months

April 1, 20141 year 0 months

April 1, 20151 year 0 months

April 1, 20161 year 0 months

April 1, 20171 year 0 months

April 1, 20181 year 0 months

April 1, 20191 year 0 months

April 1, 20201 year 0 months

April 1, 20211 year 0 months

April 1, 2022 1 year 0 months

April 1, 20231 year 0 months

April 1, 20241 year 0 months

April 1, 20251 year 0 months

April 1, 20261 year 0 months

April 1, 20271 year 0 months

April 1, 20281 year 0 months

April 1, 20291 year 0 months

April 1, 20301 year 0 months

April 1, 2031 Remaining
$-1.09 \%$
$-1.52 \%$
$-1.2 \%$
$-0.87 \%$
$-0.35 \%$
$-0.79 \%$
$-0.8 \%$
$-0.27 \%$
$0.36 \%$
$0.36 \%$
$0.62 \%$
$0.79 \%$
$0.79 \%$
$0.43 \%$
$0.61 \%$
$0.26 \%$
$0.26 \%$
$0.26 \%$
$0.17 \%$
$0.26 \%$
$0.25 \%$
$0.17 \%$
$0.25 \%$
$0.25 \%$
$0.25 \%$
$0.17 \%$
$0.22 \%$

\section{Component: AC System and Air Distribution}

\section{Initial Investment}

Initial Cost (base-year \$): $\quad \$ 210,000$

Annual Rate of Increase: $\quad \quad 0 \%$

Expected Asset Life: $\quad 20$ years 0 months

Residual Value Factor: $\quad 0 \%$

\section{Cost-Phasing}

Cost Adjustment Factor: 0\%

Years/Months (from Date) Date Portion 0 years 0 months June 1, $2001 \quad 100 \%$

\section{Replacement: Compressor/Condens}

Years/Months: $\quad 15$ years 0 months

Amount:

$\$ 31,130$

Annual Rate Of Increase:

$0 \%$

Expected Asset Life: 15 years 0 months

Residual Value Factor: $\quad 67 \%$ 
Recurring OM\&R: Routine OM\&R

Amount: $\quad \$ 530$

Annual Rate of Increase: $\quad 0 \%$

Usage Indices

From Date Duration Factor

June 1, 2002 Remaining 100\%

Non-Recurring OM\&R: Scheduled Repair1

Years/Months: $\quad 5$ years 0 months

Amount: $\quad \$ 6,300$

Annual Rate of Increase: $\quad \quad 0 \%$

Non-Recurring OM\&R: Scheduled Repair2

Years/Months: $\quad 10$ years 0 months

Amount: $\quad \$ 6,300$

Annual Rate of Increase: $\quad \quad 0 \%$

Non-Recurring OM\&R: Scheduled Repair3

Years/Months: $\quad 15$ years 0 months

Amount: $\quad \$ 6,300$

Annual Rate of Increase: $\quad 0 \%$

\section{Alternative: Central Plant Connection}

Comment: Install piping network to connect officebuilding to central chilled water plant

Energy: Electricity

Annual Consumption: $112,000.0 \mathrm{kWh}$

Price per Unit: $\quad \$ 0.08711$

Demand Charge: $\quad \$ 0$

Utility Rebate: $\quad \$ 0$

Location: Virginia

Rate Schedule: Industrial

State: Virginia

Usage Indices

From Date Duration Usage Index

June 1, 2002 Remaining $\quad 100 \%$

Escalation Rates

From Date Duration Escalation

April 1, 20011 year 0 months $\quad-1.99 \%$

April 1, 20021 year 0 months $\quad-1.22 \%$

April 1, 20031 year 0 months $\quad-0.25 \%$

April 1, 20041 year 0 months $\quad-1.32 \%$

April 1, 20051 year 0 months $\quad-1.09 \%$

April 1, 20061 year 0 months $\quad-1.52 \%$

April 1, 20071 year 0 months $\quad-1.2 \%$

April 1, 20081 year 0 months $\quad-0.87 \%$ 
April 1, 20091 year 0 months

April 1, 20101 year 0 months

April 1, 20111 year 0 months

April 1, 20121 year 0 months

April 1, 20131 year 0 months

April 1, 20141 year 0 months

April 1, 20151 year 0 months

April 1, 20161 year 0 months

April 1, 20171 year 0 months

April 1, 20181 year 0 months

April 1, 20191 year 0 months

April 1, 2020 1 year 0 months

April 1, 20211 year 0 months

April 1, 20221 year 0 months

April 1, 20231 year 0 months

April 1, 20241 year 0 months

April 1, 20251 year 0 months

April 1, 20261 year 0 months

April 1, 20271 year 0 months

April 1, 20281 year 0 months

April 1, 20291 year 0 months

April 1, 20301 year 0 months

April 1, 2031 Remaining
$-0.35 \%$

$-0.79 \%$

$-0.8 \%$

$-0.27 \%$

$0.36 \%$

$0.36 \%$

$0.62 \%$

$0.79 \%$

$0.79 \%$

$0.43 \%$

$0.61 \%$

$0.26 \%$

$0.26 \%$

$0.26 \%$

$0.17 \%$

$0.26 \%$

$0.25 \%$

$0.17 \%$

$0.25 \%$

$0.25 \%$

$0.25 \%$

$0.17 \%$

$0.22 \%$

\section{Component: Piping Network and Air Distribution}

\section{Initial Investment}

Initial Cost (base-year \$): $\quad \$ 265,000$

Annual Rate of Increase: $\quad 0 \%$

Expected Asset Life: 20 years 0 months

Residual Value Factor: $\quad 0 \%$

Cost-Phasing

Cost Adjustment Factor: 0\%

Years/Months (from Date) Date Portion

0 years 0 months June 1, $2001 \quad 100 \%$

Recurring OM\&R: Routine OM\&R

Amount: $\quad \$ 126$

Annual Rate of Increase： $0 \%$

Usage Indices

From Date Duration Factor

June 1, 2002 Remaining 100\%

Non-Recurring OM\&R: Scheduled Repair1

Years/Months: $\quad 3$ years 0 months

Amount: $\quad \$ 950$

Annual Rate of Increase: $\quad \quad 0 \%$ 
Non-Recurring OM\&R: Scheduled Repair2

Years/Months: $\quad 9$ years 0 months

Amount: $\quad \$ 950$

Annual Rate of Increase: $\quad \quad 0 \%$

Non-Recurring OM\&R: Scheduled Repair3

Years/Months: $\quad 15$ years 0 months

Amount: $\quad \$ 950$

Annual Rate of Increase: $\quad 0 \%$

Non-Recurring OM\&R: Scheduled Repair1

Years/Months: $\quad 18$ years 0 months

Amount: $\quad \$ 950$

Annual Rate of Increase: $\quad 0 \%$

\section{Alternative: Postponed Central Plant Connection}

Comment: $\quad$ Postpone installation of piping network to 2004 to coincide with general over- haul of Central Plant. The AC system would become operational in 2005 .

\section{Energy: Electricity - after connection}

Annual Consumption: 112,000.0 kWh

Price per Unit: $\quad \$ 0.08711$

Demand Charge: $\quad \$ 0$

Utility Rebate: $\$ 0$

Location: Virginia

Rate Schedule: Industrial

State: Virginia

Usage Indices

From Date Duration Usage Index

June 1, 20023 years 0 months $\quad 0 \%$

June 1, 2005 Remaining 100\%

Escalation Rates

From Date Duration Escalation

April 1, 20011 year 0 months $\quad-1.99 \%$

April 1, 20021 year 0 months $\quad-1.22 \%$

April 1, 20031 year 0 months $\quad-0.25 \%$

April 1, 20041 year 0 months $\quad-1.32 \%$

April 1, 20051 year 0 months $\quad-1.09 \%$

April 1, 20061 year 0 months $\quad-1.52 \%$

April 1, 20071 year 0 months $\quad-1.2 \%$

April 1, 20081 year 0 months $\quad-0.87 \%$

April 1, 20091 year 0 months $\quad-0.35 \%$

April 1, 20101 year 0 months $\quad-0.79 \%$

April 1, 20111 year 0 months $\quad-0.8 \%$ 
April 1, 20121 year 0 months

April 1, 20131 year 0 months

April 1, 20141 year 0 months

April 1, 20151 year 0 months

April 1, 20161 year 0 months

April 1, 20171 year 0 months

April 1, 20181 year 0 months

April 1, 20191 year 0 months

April 1, 20201 year 0 months

April 1, 20211 year 0 months

April 1, 20221 year 0 months

April 1, 20231 year 0 months

April 1, 20241 year 0 months

April 1, 20251 year 0 months

April 1, 20261 year 0 months

April 1, 20271 year 0 months

April 1, 20281 year 0 months

April 1, 20291 year 0 months

April 1, 20301 year 0 months

April 1, 2031 Remaining

$$
\begin{array}{r}
-0.27 \% \\
0.36 \% \\
0.36 \% \\
0.62 \% \\
0.79 \% \\
0.79 \% \\
0.43 \% \\
0.61 \% \\
0.26 \% \\
0.26 \% \\
0.26 \% \\
0.17 \% \\
0.26 \% \\
0.25 \% \\
0.17 \% \\
0.25 \% \\
0.25 \% \\
0.25 \% \\
0.17 \% \\
0.22 \%
\end{array}
$$

\section{Energy: Electricity - before connection}

Annual Consumption: $290,000.0 \mathrm{kWh}$

Price per Unit: $\quad \$ 0.08711$

Demand Charge: $\quad \$ 0$

Utility Rebate: $\quad \$ 0$

Location: Virginia

Rate Schedule: Industrial

State: Virginia

\section{Usage Indices}

From Date Duration Usage Index

June 1, 20023 years 0 months $\quad$ 100\%

June 1, 2005 Remaining $\quad 0 \%$

\section{Escalation Rates}

From Date Duration Escalation

April 1, 20011 year 0 months $\quad-1.99 \%$

April 1, 20021 year 0 months $\quad-1.22 \%$

April 1, 20031 year 0 months $\quad-0.25 \%$

April 1, 20041 year 0 months $\quad-1.32 \%$

April 1, 20051 year 0 months $\quad-1.09 \%$

April 1, 20061 year 0 months $\quad-1.52 \%$

April 1, 20071 year 0 months $\quad-1.2 \%$

April 1, 20081 year 0 months $\quad-0.87 \%$

April 1, 20091 year 0 months $\quad-0.35 \%$

April 1, 20101 year 0 months $\quad-0.79 \%$

April 1, 20111 year 0 months $\quad-0.8 \%$

April 1, 20121 year 0 months $\quad-0.27 \%$ 
April 1, 20131 year 0 months

April 1, 20141 year 0 months

April 1, 20151 year 0 months

April 1, 20161 year 0 months

April 1, 20171 year 0 months

April 1, 20181 year 0 months

April 1, 20191 year 0 months

April 1, 20201 year 0 months

April 1, 20211 year 0 months

April 1, 20221 year 0 months

April 1, 20231 year 0 months

April 1, 20241 year 0 months

April 1, 20251 year 0 months

April 1, 20261 year 0 months

April 1, 20271 year 0 months

April 1, 20281 year 0 months

April 1, 20291 year 0 months

April 1, 2030 1 year 0 months

April 1, 2031 Remaining
$0.36 \%$
$0.36 \%$
$0.62 \%$
$0.79 \%$
$0.79 \%$
$0.43 \%$
$0.61 \%$
$0.26 \%$
$0.26 \%$
$0.26 \%$
$0.17 \%$
$0.26 \%$
$0.25 \%$
$0.17 \%$
$0.25 \%$
$0.25 \%$
$0.25 \%$
$0.17 \%$
$0.22 \%$

\section{Component: Piping Network and Air Distribution}

\section{Initial Investment}

Initial Cost (base-year \$): $\quad \$ 225,250$

Annual Rate of Increase:

Expected Asset Life: $\quad 20$ years 0 months

Residual Value Factor: $\quad 15 \%$

Cost-Phasing

Cost Adjustment Factor: 0\%

Years/Months (from Date) Date Portion

3 years 0 months June 1, $2004 \quad 100 \%$

Recurring OM\&R: Routine OM\&R - after connection

Amount: $\quad \$ 126$

Annual Rate of Increase: $\quad 0 \%$

Usage Indices

From Date Duration Factor

June 1, 20023 years 0 months $\quad 0 \%$

June 1, 2005 Remaining 100\%

Recurring OM\&R: Routine OM\&R - before connection

Amount: $\quad \$ 1,050$

Annual Rate of Increase: $\quad 2.0 \%$

Usage Indices

From Date Duration Factor

June 1, 20023 years 0 months 100\% 
June 1, $2005 \quad$ Remaining $\quad 0 \%$

Non-Recurring OM\&R: Scheduled Repair1

Years/Months: $\quad 6$ years 0 months

Amount: $\quad \$ 950$

Annual Rate of Increase: $\quad 0 \%$

Non-Recurring OM\&R: Scheduled Repair2

Years/Months: 12 years 0 months

Amount: $\quad \$ 950$

Annual Rate of Increase: $\quad 0 \%$

Non-Recurring OM\&R: Scheduled Repair3

Years/Months: 18 years 0 months

Amount: $\quad \$ 950$

Annual Rate of Increase: $\quad$ : $\quad$ \%

\section{Alternative: DX Split System w/higher E-cost}

Comment: Install split-system central AC unit. Sensitivity Analysis with 35\% increase in energy costs

\section{Energy: Electricity}

Annual Consumption: $162,446.0 \mathrm{kWh}$

Price per Unit: $\quad \$ 0.08711$

Demand Charge: $\quad \$ 0$

Utility Rebate: $\quad \$ 0$

Location: $\quad$ Virginia

Rate Schedule: Industrial

State: Virginia

Usage Indices

From Date Duration Usage Index

June 1, 2002 Remaining 100\%

Escalation Rates

From Date Duration Escalation

April 1, 20011 year 0 months $\quad-1.99 \%$

April 1, 20021 year 0 months $\quad-1.22 \%$

April 1, 20031 year 0 months $\quad-0.25 \%$

April 1, 20041 year 0 months $\quad-1.32 \%$

April 1, 20051 year 0 months $\quad-1.09 \%$

April 1, 20061 year 0 months $\quad-1.52 \%$

April 1, 20071 year 0 months $\quad-1.2 \%$

April 1, 20081 year 0 months $\quad-0.87 \%$

April 1, 20091 year 0 months $\quad-0.35 \%$

April 1, 20101 year 0 months $\quad-0.79 \%$

April 1, 20111 year 0 months $\quad-0.8 \%$

April 1, 20121 year 0 months $\quad-0.27 \%$

April 1, 20131 year 0 months $\quad 0.36 \%$

April 1, 20141 year 0 months $\quad 0.36 \%$ 
April 1, 20151 year 0 months

April 1, 20161 year 0 months

April 1, 20171 year 0 months

April 1, 20181 year 0 months

April 1, 20191 year 0 months

April 1, 20201 year 0 months

April 1, 20211 year 0 months

April 1, 20221 year 0 months

April 1, 20231 year 0 months

April 1, 20241 year 0 months

April 1, 20251 year 0 months

April 1, 20261 year 0 months

April 1, 20271 year 0 months

April 1, 20281 year 0 months

April 1, 2029 1 year 0 months

April 1, 20301 year 0 months

April 1, 2031 Remaining
$0.62 \%$

$0.79 \%$

$0.79 \%$

$0.43 \%$

$0.61 \%$

$0.26 \%$

$0.26 \%$

$0.26 \%$

$0.17 \%$

$0.26 \%$

$0.25 \%$

$0.17 \%$

$0.25 \%$

$0.25 \%$

$0.25 \%$

$0.17 \%$

$0.22 \%$

\section{Component: Copy of: AC System and Air Distribution}

\section{Initial Investment}

Initial Cost (base-year \$): $\quad \$ 210,000$

Annual Rate of Increase:

Expected Asset Life: 20 years 0 months

Residual Value Factor: $\quad 0 \%$

\section{Cost-Phasing}

Cost Adjustment Factor: 0\%

Years/Months (from Date) Date Portion

0 years 0 months June 1, $2001 \quad 100 \%$

\section{Replacement: Compressor/Condens}

Years/Months: $\quad 15$ years 0 months

Amount:

$\$ 31,130$

Annual Rate Of Increase:

Expected Asset Life: 15 years 0 months

Residual Value Factor: $\quad 67 \%$

\section{Recurring OM\&R: Routine OM\&R}

Amount: $\quad \$ 530$

Annual Rate of Increase: $\quad 0 \%$

Usage Indices

From Date Duration Factor

June 1, 2002 Remaining 100\% 
Non-Recurring OM\&R: Scheduled Repair1

Years/Months: $\quad 5$ years 0 months

Amount: $\quad \$ 6,300$

Annual Rate of Increase: $\quad \quad 0 \%$

Non-Recurring OM\&R: Scheduled Repair2

Years/Months: $\quad 10$ years 0 months

Amount: $\quad \$ 6,300$

Annual Rate of Increase: $\quad 0 \%$

Non-Recurring OM\&R: Scheduled Repair3

Years/Months: $\quad 15$ years 0 months

Amount: $\quad \$ 6,300$

Annual Rate of Increase: $\quad$ $\quad$ \% 


\section{NIST BLCC 5.0-01: Lowest LCC}

Consistent with Federal Life Cycle Cost Methodology and Procedures, 10 CFR, Part 436, Subpart A

\section{General Information}

File Name:

Run Date:

Analysis Type:

Project Name:

Project Location:

Analyst:

Comment:

Base Date:

Service Date:

Study Period:

Discount Rate:

Discounting

Convention:
C: $\backslash$ Program Files $\backslash$ BLCC5 $\backslash$ projects $\backslash$ Class Exercise D2.xml

Thu Sep 20 11:18:23 EDT 2001

Federal Analysis, Agency-Funded Project

Class Exercise D2

Virginia

SKF

Provide economical and effective air conditioning for the family housing office at the Dahlgren, VA

Naval Station.

June 1, 2001

June 1, 2002

21 years 0 months (June 1, 2001 through May 31, 2022)

\section{Lowest LCC}

Comparative Present-Value Costs of Alternatives

(Shown in Ascending Order of Initial Cost, * = Lowest LCC)

Alternative

Existing System

Postponed Central Plant Connection

DX Split System

DX Split System w/higher E-cost

Central Plant Connection
Initial Cost (PV) Life Cycle Cost (PV)

$\$ 0$

$\$ 204,340$

$\$ 210,000$

$\$ 372,359$

$\$ 363,854$ *

$\$ 210,000$

$\$ 377,070$

$\$ 265,000$

$\$ 425,446$

$\$ 398,039$

Mid-Year 


\section{NIST BLCC 5.0-01: Summary LCC \\ Consistent with Federal Life Cycle Cost Methodology and Procedures, 10 CFR, Part 436, Subpart A}

\section{General Information}

File Name:

Run Date:

Analysis Type:

Project Name:

Project Location:

Analyst:

Comment:

Base Date:

Service Date:

Study Period:

Discount Rate:

Discounting

Convention:
C: $\backslash$ Program Files $\backslash$ BLCC5 $\backslash$ projects $\backslash$ Class Exercise D2.xml

Thu Sep 20 11:20:22 EDT 2001

Federal Analysis, Agency-Funded Project

Class Exercise D2

Virginia

SKF

Provide economical and effective air conditioning for the family housing office at the Dahlgren, VA Naval Station.

June 1, 2001

June 1, 2002

21 years 0 months (June 1, 2001 through May 31, 2022)

Mid-Year

Discount and Escalation Rates are REAL (exclusive of general inflation)

\section{Alternative: Existing System}

\section{LCC Summary}

Initial Cost

Energy Consumption Costs

Energy Demand Costs

Energy Utility Rebates

Water Usage Costs

Water Disposal Costs

Annually Recurring OM\&R Costs

Non-Annually Recurring OM\&R Costs

Replacement Costs

Less Remaining Value

Total Life-Cycle Cost

Present Value Annual Value

$\begin{array}{rr}\$ 0 & \$ 0 \\ \$ 333,102 & \$ 22,241 \\ \$ 0 & \$ 0 \\ \$ 0 & \$ 0 \\ \$ 0 & \$ 0 \\ \$ 0 & \$ 0 \\ \$ 18,318 & \$ 1,223 \\ \$ 20,939 & \$ 1,398 \\ \$ 0 & \$ 0 \\ \$ 0 & \$ 0 \\ -------- \\ \$ 372,359 & \$ 24,862\end{array}$

\section{Alternative: DX Split System}

\section{LCC Summary}

Initial Cost

Energy Consumption Costs

Energy Demand Costs

Energy Utility Rebates

Water Usage Costs

Water Disposal Costs
Present Value Annual Value

$\begin{array}{rr}\$ 210,000 & \$ 14,021 \\ \$ 138,214 & \$ 9,228 \\ \$ 0 & \$ 0 \\ \$ 0 & \$ 0 \\ \$ 0 & \$ 0 \\ \$ 0 & \$ 0\end{array}$




$\begin{array}{lrr}\text { Annually Recurring OM\&R Costs } & \$ 7,547 & \$ 504 \\ \text { Non-Annually Recurring OM\&R Costs } & \$ 13,340 & \$ 891 \\ \text { Replacement Costs } & \$ 18,517 & \$ 1,236 \\ \text { Less Remaining Value } & -\$ 10,549 & -\$ 704 \\ & -------- & --------- \\ \text { Total Life-Cycle Cost } & \$ 377,070 & \$ 25,176\end{array}$

\section{Alternative: Central Plant Connection}

\section{LCC Summary}

$\begin{array}{lrr}\text { Initial Cost } & \$ 265,000 & \$ 17,694 \\ \text { Energy Consumption Costs } & \$ 128,646 & \$ 8,590 \\ \text { Energy Demand Costs } & \$ 0 & \$ 0 \\ \text { Energy Utility Rebates } & \$ 0 & \$ 0 \\ \text { Water Usage Costs } & \$ 0 & \$ 0 \\ \text { Water Disposal Costs } & \$ 0 & \$ 0 \\ \text { Annually Recurring OM\&R Costs } & \$ 1,794 & \$ 120 \\ \text { Non-Annually Recurring OM\&R Costs } & \$ 2,599 & \$ 174 \\ \text { Replacement Costs } & \$ 0 & \$ 0 \\ \text { Less Remaining Value } & \$ 0 & \$ 0 \\ & --------- & ---------- \\ \text { Total Life-Cycle Cost } & \$ 398,039 & \$ 26,577\end{array}$

\section{Alternative: Postponed Central Plant Connection}

\section{LCC Summary}

Initial Cost

Energy Consumption Costs

Energy Demand Costs

Energy Utility Rebates

Water Usage Costs

Water Disposal Costs

Annually Recurring OM\&R Costs

Non-Annually Recurring OM\&R Costs

Replacement Costs

Less Remaining Value

Total Life-Cycle Cost
Present Value Annual Value

$\begin{array}{rr}\$ 204,340 & \$ 13,644 \\ \$ 170,211 & \$ 11,365 \\ \$ 0 & \$ 0 \\ \$ 0 & \$ 0 \\ \$ 0 & \$ 0 \\ \$ 0 & \$ 0 \\ \$ 4,498 & \$ 300 \\ \$ 1,892 & \$ 126 \\ \$ 0 & \$ 0 \\ -\$ 17,088 & -\$ 1,141 \\ ---------- & ----------- \\ \$ 363,854 & \$ 24,294\end{array}$




\section{Alternative: DX Split System w/higher E-cost}

\section{LCC Summary}

$\begin{array}{lrr}\text { Initial Cost } & \$ 210,000 & \$ 14,021 \\ \text { Energy Consumption Costs } & \$ 186,590 & \$ 12,458 \\ \text { Energy Demand Costs } & \$ 0 & \$ 0 \\ \text { Energy Utility Rebates } & \$ 0 & \$ 0 \\ \text { Water Usage Costs } & \$ 0 & \$ 0 \\ \text { Water Disposal Costs } & \$ 0 & \$ 0 \\ \text { Annually Recurring OM\&R Costs } & \$ 7,547 & \$ 504 \\ \text { Non-Annually Recurring OM\&R Costs } & \$ 13,340 & \$ 891 \\ \text { Replacement Costs } & \$ 18,517 & \$ 1,236 \\ \text { Less Remaining Value } & -\$ 10,549 & -\$ 704 \\ & ---------- & ----------- \\ \text { Total Life-Cycle Cost } & \$ 425,446 & \$ 28,406\end{array}$




\section{NIST BLCC 5.0-01: Comparative Analysis}

Consistent with Federal Life Cycle Cost Methodology and Procedures, 10 CFR, Part 436, Subpart A

\section{Base Case: Existing System}

\section{Alternative: DX Split System}

\section{General Information}

File Name:

Run Date:

Project Name:

Project Location:

Analysis Type:

Analyst:

Comment

Base Date of Study:

Service Date:

Study Period:

Discount Rate:

Discounting

Convention:
$\mathrm{C}: \backslash$ Program Files $\backslash$ BLCC5 $\backslash$ projects $\backslash$ Class Exercise D2.xml

Thu Sep 20 11:21:33 EDT 2001

Class Exercise D2

Virginia

Federal Analysis, Agency-Funded Project

SKF

Provide economical and effective air conditioning for the family housing office at the Dahlgren,

VA Naval Station.

June 1, 2001

June 1, 2002

21 years 0 months(June 1, 2001 through May 31, 2022)

$3.3 \%$

Mid-Year

\section{Comparison of Present-Value Costs \\ PV Life-Cycle Cost}

Base Case Alternative Savings from Alternative

Initial Investment Costs:

Capital Requirements as of Base Date

$\$ 0 \$ 210,000$

$-\$ 210,000$

Future Costs:

Energy Consumption Costs

$\$ 333,102 \quad \$ 138,214$

$\$ 194,887$

Energy Demand Charges

$\$ 0 \quad \$ 0$

$\$ 0$

Energy Utility Rebates

$\$ 0$

$\$ 0$

$\$ 0$

Water Costs

$\$ 0$

$\$ 0$

$\$ 0$

Recurring and Non-Recurring OM\&R Costs

Capital Replacements

$\$ 39,257$

$\$ 20,888$

$\$ 18,369$

$\$ 0 \quad \$ 18,517$

$-\$ 18,517$

$\$ 0 \quad-\$ 10,549$

$\$ 10,549$

Residual Value at End of Study Period

Subtotal (for Future Cost Items)
$\$ 372,359 \quad \$ 167,070$

$\$ 205,288$ 
Net Savings from Alternative Compared with Base Case

PV of Non-Investment Savings $\$ 213,257$

- Increased Total Investment $\$ 217,969$

Net Savings

$-\$ 4,712$

Savings-to-Investment Ratio (SIR)

$\mathbf{S I R}=0.98$

SIR is lower than 1.0; project alternative is not cost effective.

\section{Adjusted Internal Rate of Return}

AIRR $=3.19 \%$

AIRR is lower than your discount rate; project alternative is not cost effective.

\section{Payback Period}

Estimated Years to Payback (from beginning of Service Period)

Simple Payback occurs in year 15

Simple Payback is negated in year 16

Simple Payback occurs in year 17

\section{Energy Savings Summary}

$\begin{array}{lcccc}\text { Energy } & \text { Savings } & \text { Summary } & \text { (in stated units) } \\ \text { Energy } & ----A v e r a g e & \text { Annual } & \text { Consumption---- } & \text { Life-Cycle } \\ \text { Type } & \text { Base Case } & \text { Alternative } & \text { Savings } & \text { Savings } \\ \text { Electricity } & 290,000.0 \mathrm{kWh} & 120,330.0 \mathrm{kWh} & 169,670.0 \mathrm{kWh} & 3,392,935.5 \mathrm{kWh} \\ \text { Energy } & \text { Savings } & \text { Summary } & \text { (in MBtu) } \\ \text { Energy } & - \text {----Average } & \text { Annual } & \text { Consumption---- } & \text { Life-Cycle } \\ \text { Type } & \text { Base Case } & \text { Alternative } & \text { Savings } & \text { Savings } \\ \text { Electricity } & 989.5 \mathrm{MBtu} & 410.6 \mathrm{MBtu} & 578.9 \mathrm{MBtu} & 11,577.2 \mathrm{MBtu}\end{array}$




\section{Emissions Reduction Summary}

\begin{tabular}{lrrrr}
$\begin{array}{l}\text { Energy } \\
\text { Type }\end{array}$ & \multicolumn{1}{c}{ - $\begin{array}{c}\text { Base Case } \\
\text { Electricity }\end{array}$} & \multicolumn{1}{c}{$\begin{array}{c}\text { Alternative } \\
\text { Reduction }\end{array}$} & \multicolumn{1}{c}{ Reduction } \\
CO2 & $266,197.98 \mathrm{~kg}$ & $110,453.80 \mathrm{~kg}$ & $155,744.17 \mathrm{~kg}$ & $3,114,457.09 \mathrm{~kg}$ \\
$\mathbf{S O 2}$ & $575.32 \mathrm{~kg}$ & $238.72 \mathrm{~kg}$ & $336.60 \mathrm{~kg}$ & $6,731.15 \mathrm{~kg}$ \\
NOx & $607.69 \mathrm{~kg}$ & $252.15 \mathrm{~kg}$ & $355.54 \mathrm{~kg}$ & $7,109.85 \mathrm{~kg}$ \\
Total: & & & & \\
CO2 & $266,197.98 \mathrm{~kg}$ & $110,453.80 \mathrm{~kg}$ & $155,744.17 \mathrm{~kg}$ & $3,114,457.09 \mathrm{~kg}$ \\
SO2 & $575.32 \mathrm{~kg}$ & $238.72 \mathrm{~kg}$ & $336.60 \mathrm{~kg}$ & $6,731.15 \mathrm{~kg}$ \\
NOx & $607.69 \mathrm{~kg}$ & $252.15 \mathrm{~kg}$ & $355.54 \mathrm{~kg}$ & $7,109.85 \mathrm{~kg}$
\end{tabular}




\section{Module E}

\section{Replace Chiller or Purchase Chilled Water}

Objectives: Upon completion of this module, you will know how to

- compare LCCs of capital investments and outsourcing,

- and when to include inflation estimates in federal LCCAs,

- use BLCC to evaluate contracted costs that include inflation adjustments. 


\section{Pros and Cons of Chiller Replacement versus Chilled Water Contract}

- CHILLER REPLACEMENT:

High initial investment cost

Significant maintenance (building engineer needed on site)

Fixed output capacity

Scheduled shutdowns may be inconvenient or impractical

Performance degradation over time

Not subject to contract renewal negotiations -- less uncertainty

- CHILLED WATER CONTRACT:

Flexible contract length

Low initial cost

Negligible maintenance

Flexible capacity

Higher reliability; no down time for maintenance

Metered output

Contract subject to renegotiation at expiration (uncertainty) 


\section{Chilled Water Contract Requires Careful Analysis}

- Capacity charge and energy charge

- Extra energy charge for low ${ }^{\mathrm{a}} \mathrm{T}$ water return

- Extra charge for unreturned chilled water

- Escalation clauses for capacity and energy charges based on ${ }^{a}$ CPI and ${ }^{a}$ gas prices

- Current dollar analysis required to include ${ }^{a}$ CPI

- Estimates of general inflation and nominal energy price escalation rates required 


\section{Exercise E1}

230 Ton Chiller Replacement in Federal Building in Texas vs. Chilled Water Contract

Chiller Replacement:

Initial cost $=\$ \mathbf{3 5 0 , 0 0 0}$

Annual kWh cost $(450,000 \mathrm{kWh} @ \$ \mathbf{\$ 0 . 0 5} / \mathrm{kWh})=\$ 22,500$

Annual kW demand charge $=\$ 5,000$

Annual make-up water cost $=\$ \mathbf{2 , 1 0 0}$

Annual in-house labor $=\$ \mathbf{1 0 , 0 0 0}$

Annual service contract/supplies $=\$ \mathbf{5 , 0 0 0}$

Expected life $=20$ years with refurbishment at end of year 10

(@) 40\% of initial cost)

Residual value $=0$ 


\section{Chilled Water Contract Proposal}

- Contract life negotiable:

- Capacity (demand) charges:

- Monthly capacity charge $=\$ \mathbf{1 3 . 0 0} /$ ton

- Excess capacity charge $=\$ \mathbf{\$ 1 3 . 0 0} /$ ton

- Excess capacity "ratchet" $=12$ months

- Partially subject to annual CPI adjustment:

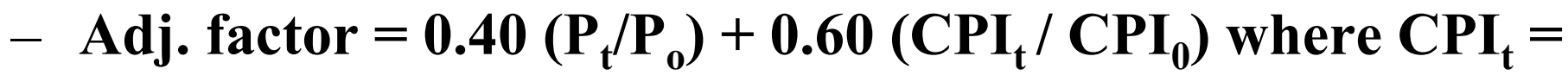
$\mathrm{CPI}$ in year $\mathrm{t}\left(\mathrm{CPI}_{0}=\mathrm{CPI}\right.$ at start of contract)

- Energy charges:

- Basic energy charge $=\$ \mathbf{\$ 0 . 0 6} /$ ton-h

- Energy efficiency charge $=\$ \mathbf{\$ 0 . 0 1} /$ ton-h $\left(\right.$ based on $\left.{ }^{\mathrm{a}} \mathbf{T}=12 \mathrm{~F}\right)$

- Energy charge subject to annual CPI and gas price adjustments

Adj. factor $=0.35\left(P_{t} / P_{0}\right)+0.65\left(\mathrm{CPI}_{t} / \mathrm{CPI}_{0}\right)$ where $\mathrm{P}_{t}=$ gas price in year $t\left(P_{0}=\right.$ gas price at start of contract $)$ 


\section{Current-Dollar or Constant- Dollar Analysis?}

- Use constant dollars when contract includes general inflation adjustment for all costs.

- Use current dollars when contract has different escalation rates for different costs. 


\section{Chiller Replacement - 20-Year Analysis}

Current-dollar analysis using DOE discount rate and inflation rate Nominal discount rate $=6.1 \%$, Inflation rate $=2.7 \%$

Initial cost

Annual electric cost

Annual make-up water

Annual in-house labor

Annual service contract

Scheduled refurbishment (year 10) 140,000

Residual value (year 20)

Total PV Cost
Cost at

Base Date

$\$ 350,000$

27,500

2,100

10,000

5,000

0
Discount

Factor

1.000

13.39

14.47

14.47

14.47

0.723

0.522
Present

Value

$\$ 350,000$

368,225

30,387

144,700

72,350

101,220

0

$\$ 1,066,882$

${ }^{a}$ from Annual Supplement to Handbook 135, page 1 


\section{Purchase Chilled Water - 20-Year Analysis}

Cost (base Discount date prices) Factor

$\$ 10,000$

Initial system modification

Annual costs (20 years):

Basic capacity charge (230 tons) $\mathbf{\$ 3 5 , 8 8 0}$

Amount not subject to CPI adj. (40\%)

Amount subject to CPI adj. (60\%)

Energy charge:

(390,000 ton-hs@\$0.07) \$27,300

Amount subject to gas price adj. (35\%)

Amount subject to CPI adj. (65\%)
14,352

21,528

$\mathbf{9 , 5 5 5}$

17,745
1.000

Present

Value

$\$ 10,000$

11.38

163,326

$14.47^{\mathrm{a}}$

311,510

Total 20-year cost $12.01^{\mathrm{b}}$

14.47
114,756

256,770

$\$ 856,362$

a Assumes 2.7\% annual CPI increase, based on inflation assumption in ASHB135.

b Based on DOE industrial gas price escalation rates for region 3 with $2.7 \%$ inflation. 


\section{Chilled Water Purchase - 10-Year Analysis}

Initial system modification

Basic capacity charge (230 tons) $\mathbf{3 5 , 8 8 0}$

Amount not subject to CPI adj. (40\%)

Amount subject to CPI adj. $\quad(60 \%)$

Cost at
base date

$\$ 10,000$

14,352

21,528

$\$ 27,300$

(390,000 ton-hs@\$0.07)

Amount subject to gas price adj. (35\%)

Amount subject to CPI adj. (65\%)

Total 20-year cost
Present

Value

Factor

1.00

$\$ 10,000$

7.33

105,200

$8.40^{\mathrm{a}}$

180,835

64,019

149,058

$\$ 509,112$

${ }^{a}$ Assumes 2.7\% annual CPI increase, based on inflation assumption in ASHB135.

b Based on DOE industrial gas price escalation rates for region 3 with $2.7 \%$ inflation. 


\section{Chiller Replacement - 10-Year Analysis}

Initial cost

Annual electric cCost

Annual make-up water

Annual in-house labor

Annual service contract

Residual value (year 10) *

Total PV Cost
Cost at Base Date

$\$ 350,000$

27,500

2,100

10,000

5,000

35,000
Discount

Factor

1.00

7.89

8.40

8.40

8.40

0.723
Present

Value

$\$ 350,000$

216,975

17,640

84,000

42,000

$(25,305)$

$\$ 685,310$

*Residual value based on 10 years remaining of 20-year life, less needed refurbishment. $\$ 175,000-\$ 140,000=\$ 35,000$ 


\section{Chiller Replacement - Years 11 to 20 2.7\% Inflation, 6.1\% Discount Rate}

Initial cost

Annual electric cost

Annual make-up water

Annual in-house labor

Annual Service contract

Scheduled refurbishment (year 10)

Residual value (year 20)

Total PV Cost
Discount

Factor

$0.723^{\mathrm{a}}$

$5.50^{\mathrm{b}}$

$6.07^{\mathrm{b}}$

$6.07^{\mathrm{b}}$

$6.07^{b}$

$0.522^{c}$

$0.522^{c}$

175,000
Present

Value

$\$ 253,050$

151,250

12,747

60,700

30,350

73,080

$(91,350)$

$\$ 489,827$

a $S P V *$ for year 10 (2.7\% inflation)

b UPV* for 20 years - UPV* for 10 years

c $\mathrm{SPV} *$ for year 20 (2.7\% inflation) 


\section{LCC Summary}

10-Year Analysis

PV 10-year chiller replacement cost

PV 10-year chilled water contract cost

$\$ 685,310$

509,112

20-Year Analysis

PV 20-year chiller replacement cost

PV 20-year chilled water contract cost

PV 10-year contract with chiller replacement at year 11

$\$ 1,066,882$

856,362

PV 10-year chilled water contract cost

PV 10-year chiller replacement at year 11

$\$ 509,112$

$+\underline{489,827}$

$\$ 998,939$ 


\section{Set Project Information}

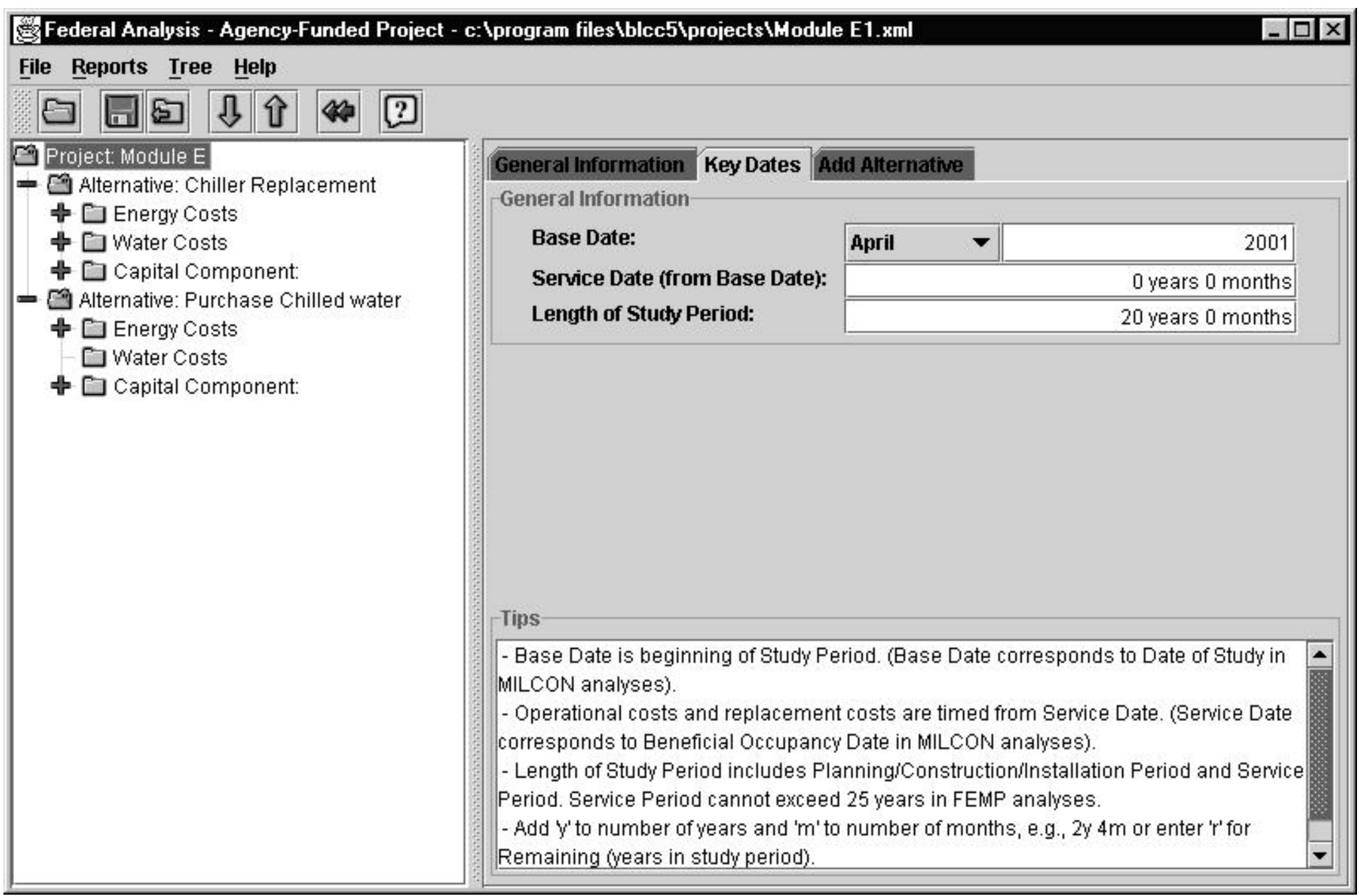




\section{Enter Electricity Use}






\section{Energy, Demand Charges, and Escalation Rates}

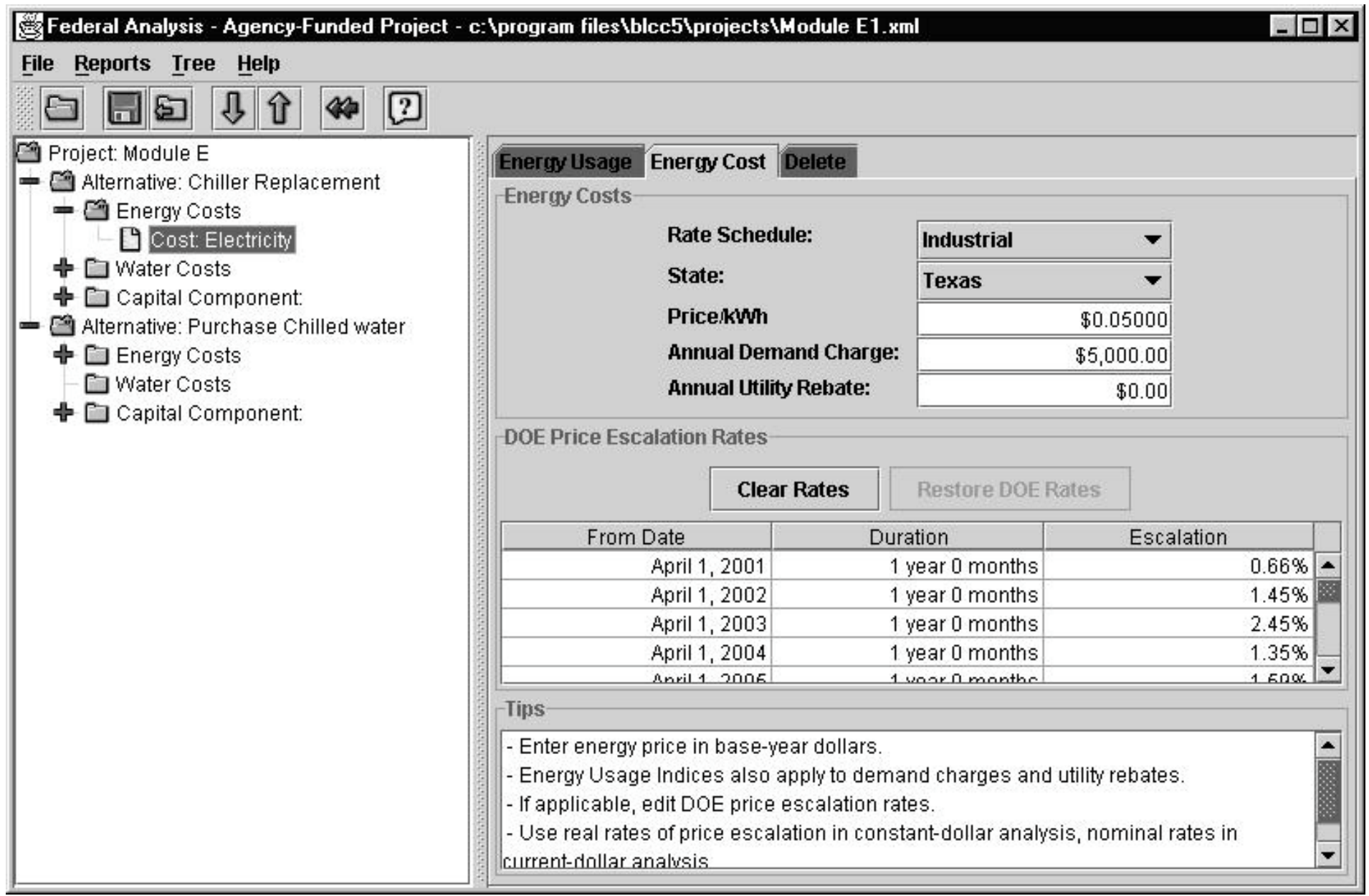




\section{Water Use, Prices, and Escalation}

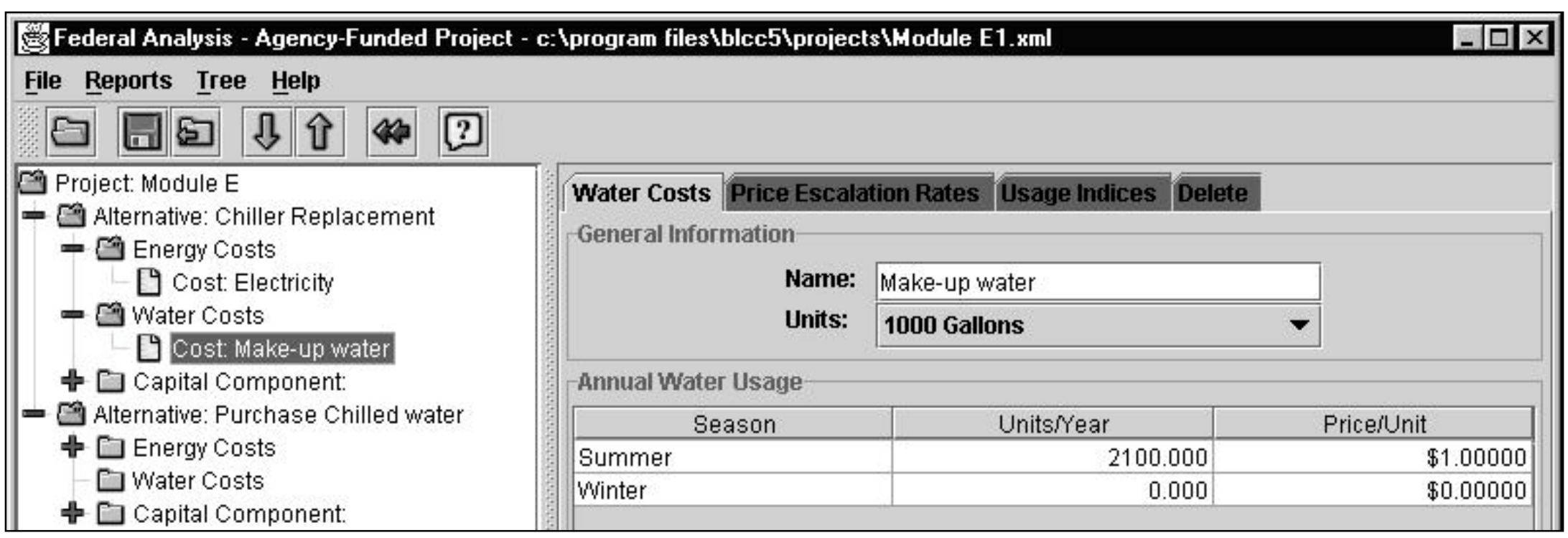

\begin{tabular}{|c|c|c|c|c|c|c|c|}
\hline \multicolumn{8}{|c|}{ Sederal Analysis - Agency-Funded Project - c:lprogram filestblcc5łprojectsłModule E1.xml } \\
\hline \multicolumn{8}{|c|}{ File Reports Iree Help } \\
\hline$\Xi$ & 四 & ภ & $\infty$ & 2 & & & \\
\hline \multirow{3}{*}{\multicolumn{4}{|c|}{ 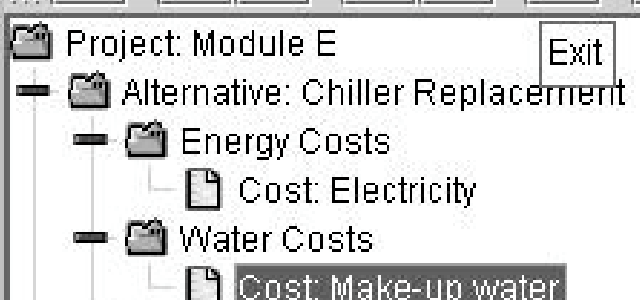 }} & & \multicolumn{3}{|c|}{ Water Costs Price Escalation Rates Usage Indices Delete } \\
\hline & & & & & From Date & Duration & Usage Cost Escalation \\
\hline & & & & & April 1,2001 & Remaining & $2.70 \%$ \\
\hline
\end{tabular}




\section{Investment Costs}

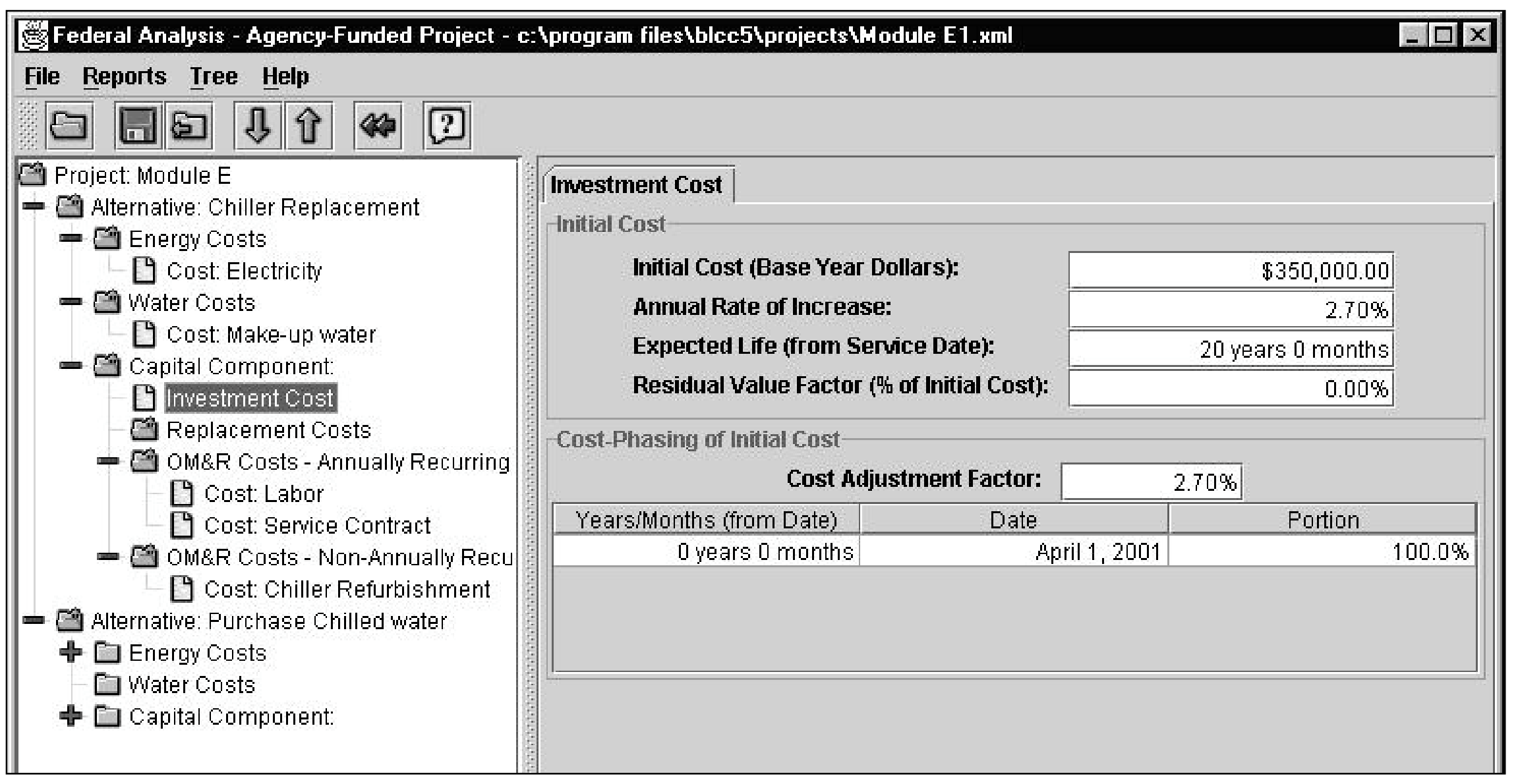




\section{Annually Recurring OM\&R Costs}

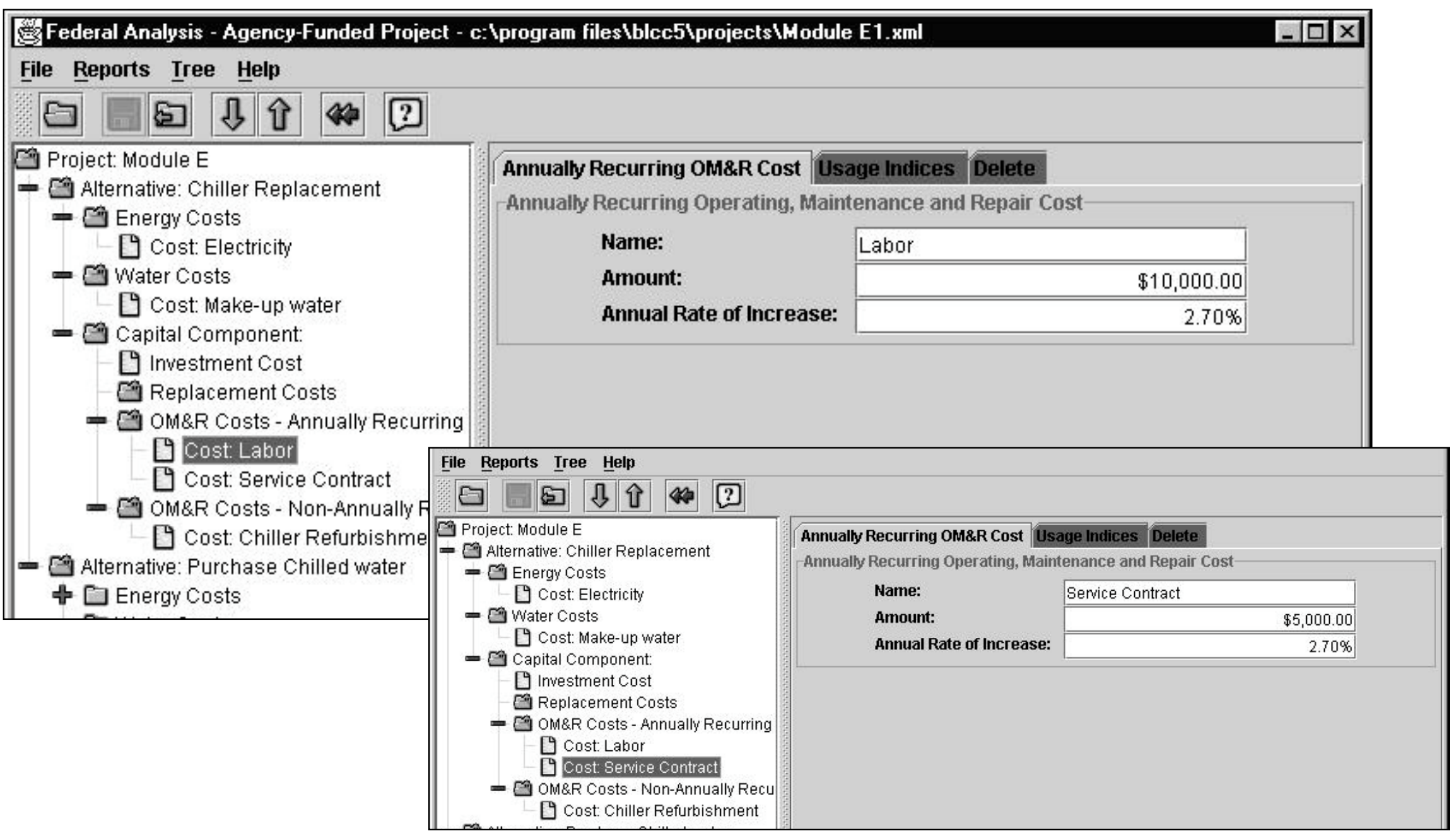




\section{Non-Annually Recurring OM\&R Costs}

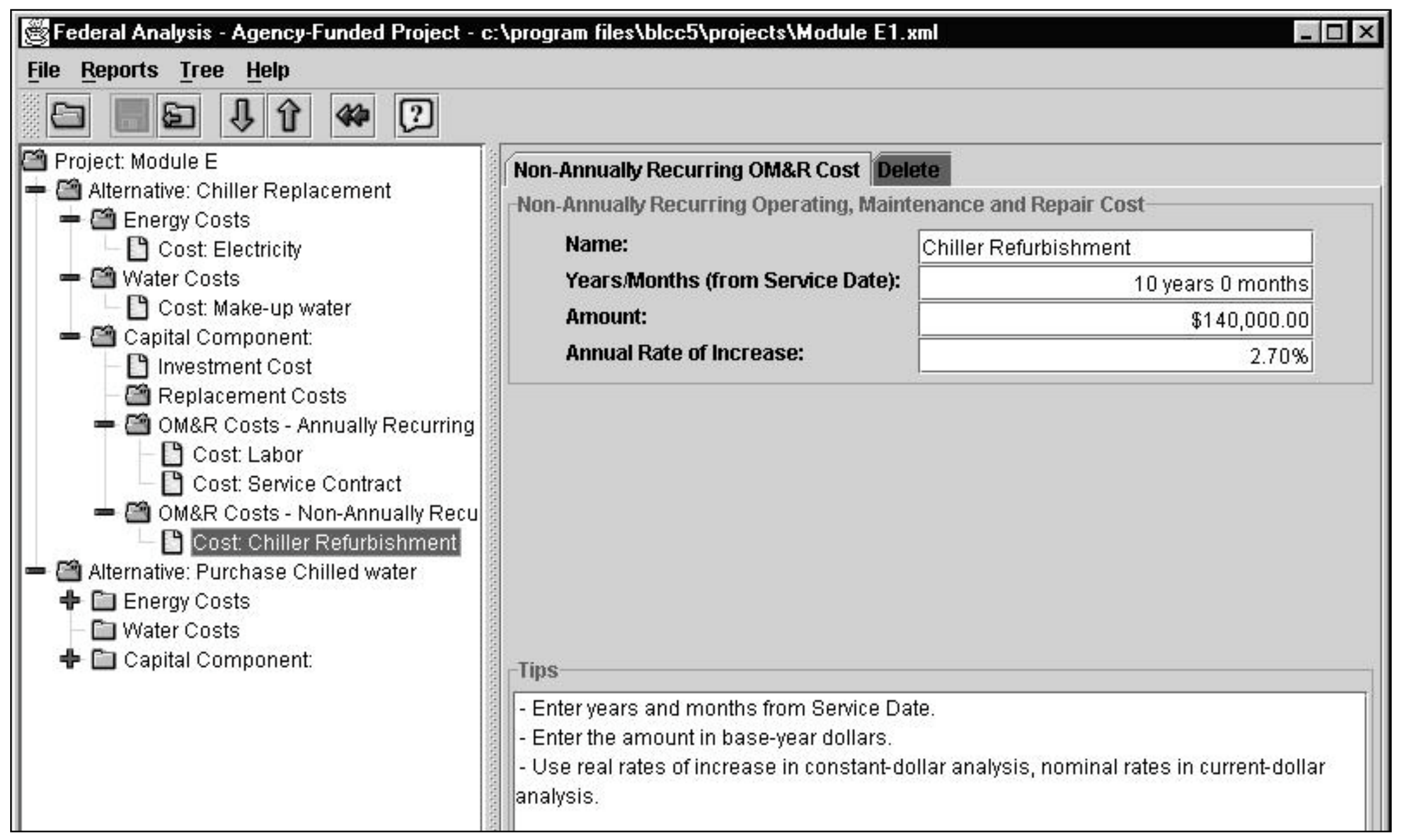




\section{Summary LCC for Replace Chiller Alternative}

\begin{tabular}{|c|c|c|}
\hline \multicolumn{3}{|l|}{ Summary Report } \\
\hline \multicolumn{3}{|l|}{ File } \\
\hline \multicolumn{3}{|c|}{$\begin{array}{l}\text { Alternative: Chiller Replacement } \\
\text { Lcc summary }\end{array}$} \\
\hline & Present value & Annual Value \\
\hline Initial Cost & $\$ 350,000$ & $\$ 30,738$ \\
\hline Energy Consumption Costs & $\$ 301,350$ & $\$ 26,465$ \\
\hline Energy Demand Costs & $\$ 66,967$ & $\$ 5,881$ \\
\hline Energy Utility Rebates & $\$ 0$ & $\$ 0$ \\
\hline Water Usage costs & $\$ 30,397$ & $\$ 2,670$ \\
\hline Water Disposal Costs & $\$ 0$ & $\$ 0$ \\
\hline Annually Recurring OM\&R Costs & $\$ 217,119$ & $\$ 19,068$ \\
\hline Non-Annually Recurring OM\&R Costs & $\$ 101,192$ & $\$ 8,887$ \\
\hline Replacement Costs & $\$ 0$ & $\$ 0$ \\
\hline Less Remaining Value & $\$ 0$ & $\$ 0$ \\
\hline Total Life-Cycle cost & $\$ 1,067,023$ & $\$ 93,708$ \\
\hline
\end{tabular}




\section{Purchase Chilled Water}

Alternative



\section{Energy costs have differing escalation rates}




\section{Non-Adjusted Capacity Cost}

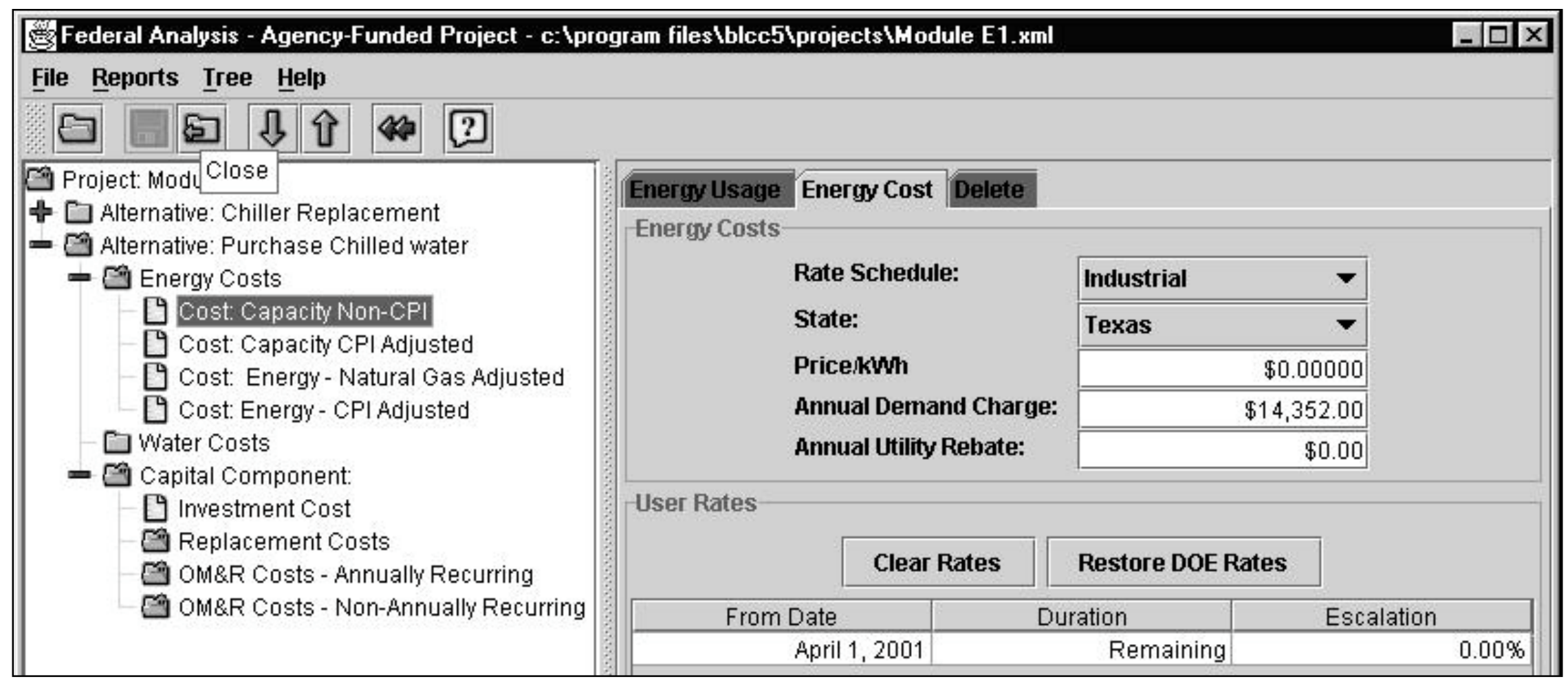




\section{CPI-Adjusted Capacity Cost}

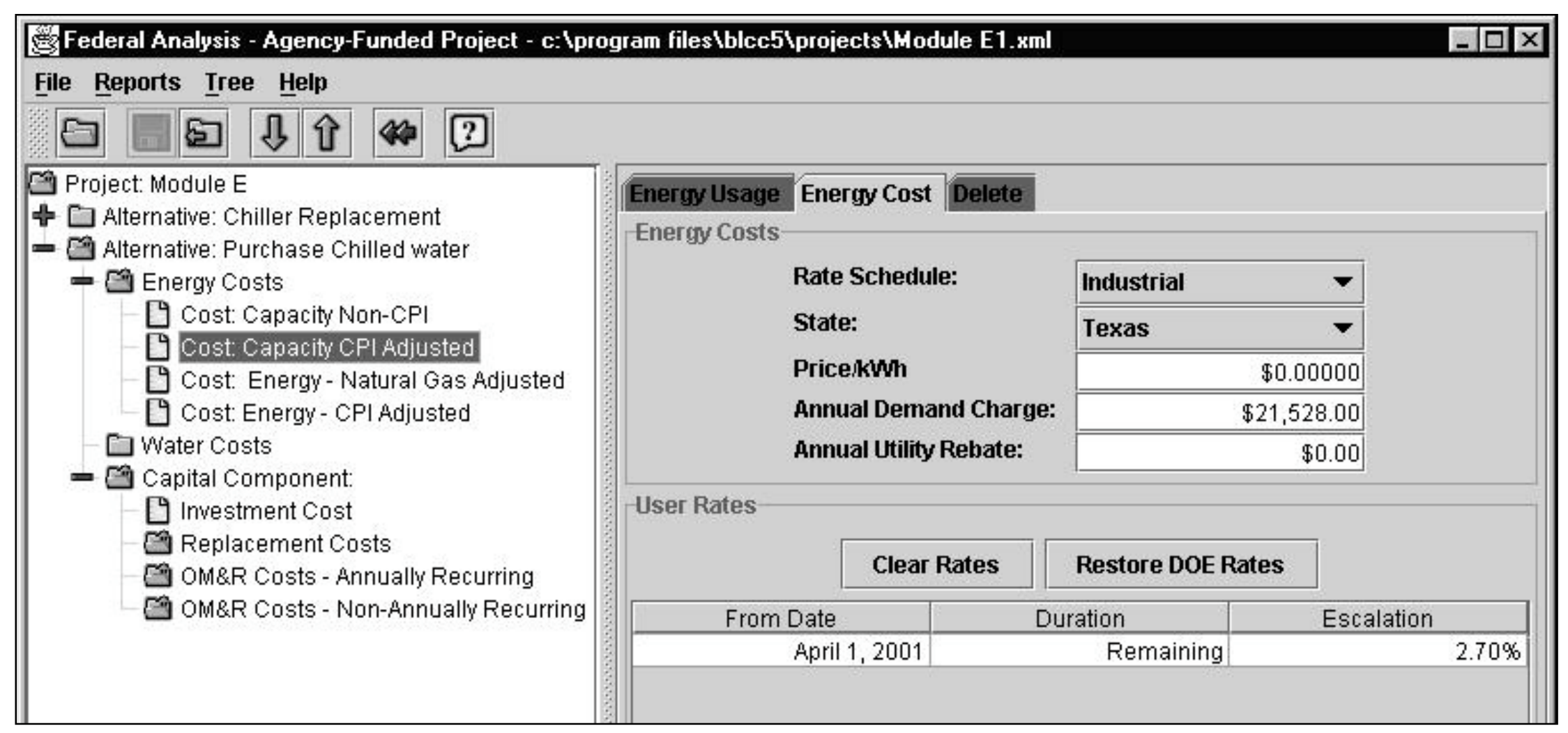




\section{DOE-Escalated Natural Gas}

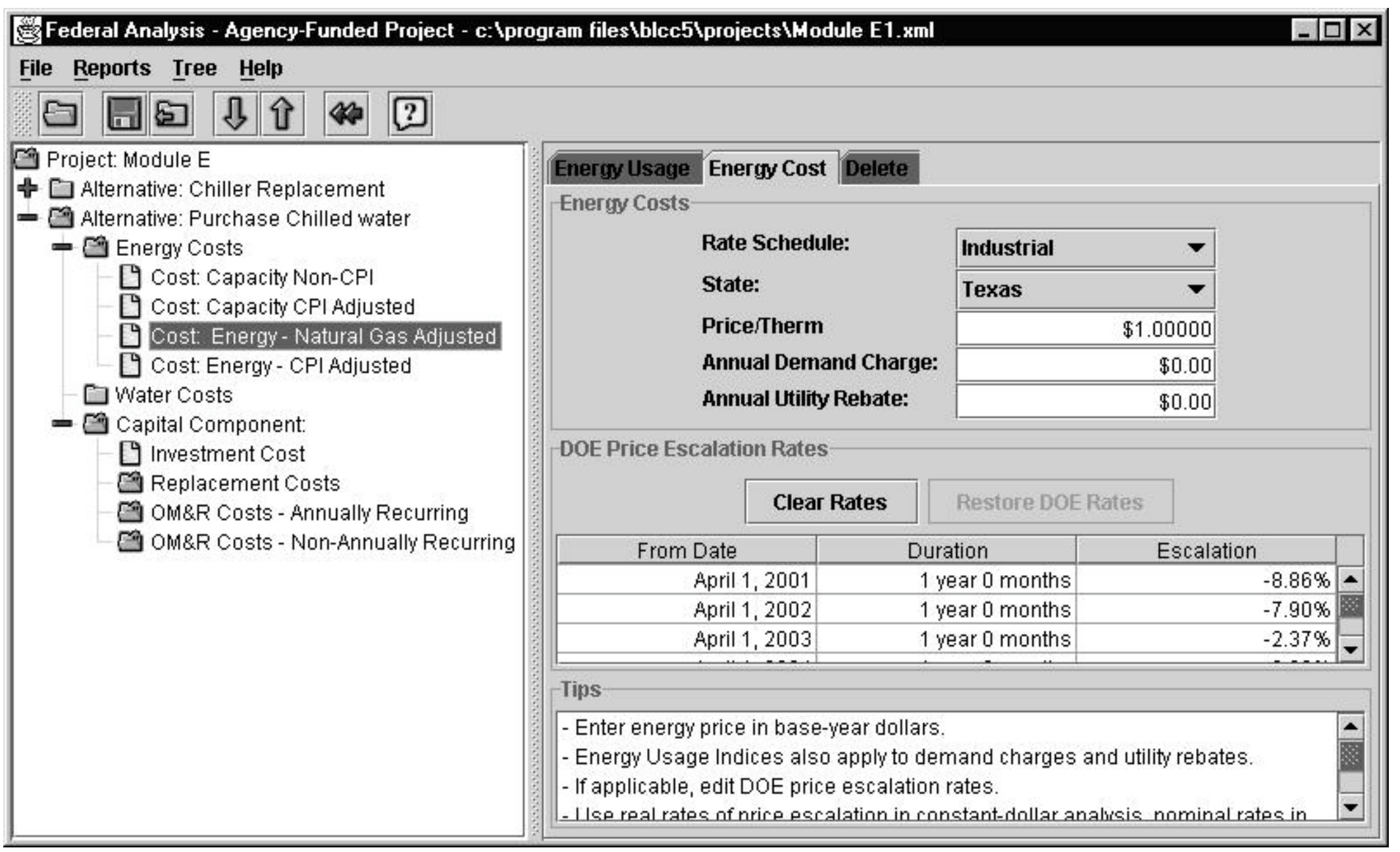




\section{CPI-Adjusted Natural Gas}

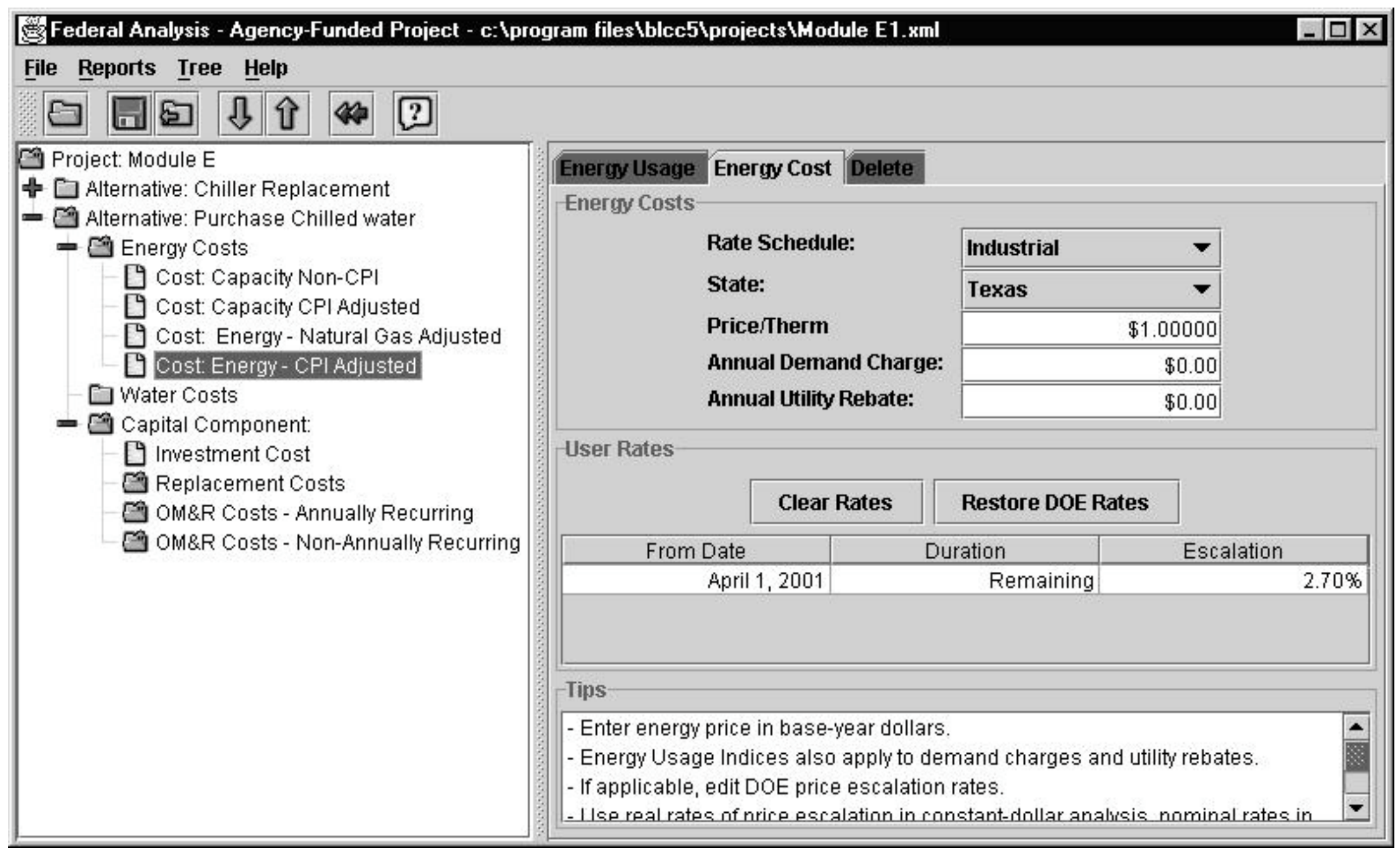




\section{Investment Cost}






\section{Summary LCC for Purchase Chilled Water Alternative}

\begin{tabular}{|c|c|c|c|}
\hline Summary Report & & & $\mathrm{X}$ \\
\hline File & & & \\
\hline Alternative: Purchase $\mathrm{Cl}$ & illed Mate & & $\triangle$ \\
\hline & Present value & Annual Value & \\
\hline Initial Cost & $\$ 10,000$ & $\$ 878$ & \\
\hline Energy Consumption Costs & $\$ 371,605$ & $\$ 32,635$ & \\
\hline Energy Demand Costs & $\$ 475,072$ & $\$ 41,722$ & \\
\hline Energy Utility Rebates & $\$ 0$ & $\$ 0$ & \\
\hline Water Usage Costs & $\$ 0$ & $\$ 0$ & \\
\hline Water Disposal Costs & $\$ 0$ & $\$ 0$ & \\
\hline Annually Recurring OM\&R Costs & $\$ 0$ & $\$ 0$ & \\
\hline Non-Annually Recurring OM\&R costs & $\$ 0$ & $\$ 0$ & $\overline{8}$ \\
\hline Replacement Costs & $\$ 0$ & $\$ 0$ & \\
\hline Less Remaining Value & $\$ 0$ & $\$ 0$ & \\
\hline Total Life-CYcle cost & $\$ 856,676$ & $\$ 75,235$ & $\bar{V}$ \\
\hline
\end{tabular}




\section{Class Exercise E2}

\section{PROBLEM STATEMENT}

The building energy coordinator has reviewed the analysis and has concluded that given present natural gas prices and DOE projections for energy escalation, it is cost-effective to enter into a contract to purchase chilled-water.

However, he is concerned about the changing price and availability of natural gas resulting from decreasing supplies and a national trend towards summer peak electrical generation using natural gas. As a result, he wants to determine the rate of natural gas price escalation that will make his decision to purchase chilled water a bad decision, i.e. not cost-effective.

His contract with the chilled water supplier is for a minimum of five years. Determine the breakeven natural gas price for a five-year study period. The breakeven gas price will be the one where the net savings is zero (equal life-cycle costs for both alternatives).

Note: The chiller's residual value will change based on the study period. Also, the chiller refurbishment is not planned until the tenth year. For the analysis, assume the residual value of the chiller for the five-year study period is $75 \%$. 


\section{Class Exercise E3}

\section{PROBLEM STATEMENT}

The manager of the buildings is still uncertain about leaving the supply of chilled water up to a third party. He has asked you to compare the life-cycle cost of purchasing chilled water for a 20 -year period versus purchasing chilled water for 10 years and then buying a chiller.

To purchase chilled water for 10 years and then purchase a chiller has the following costs:

Purchase chilled water contract cost $=\$ 10,000$

Purchase chiller in year $10=\$ 350,000$

First 10 years

Capacity charge, $\$ 35,880$, of which $40 \%$ is not adjusted and $60 \%$ is adjusted for inflation.

Energy charge, $\$ 27,300$, of which $35 \%$ is adjusted for changing natural gas prices and $65 \%$ is adjusted for inflation.

Years 11-20

Energy costs for $450,000 \mathrm{kWh}$ at $\$ 0.05$ per $\mathrm{kWh}$ plus $\$ 5,000$ demand charges, both adjusted for changing electricity prices.

Make-up water costs of \$2,100 annually, adjusted for inflation.

In-house labor of $\$ 2,100$ annually.

Service contract of $\$ 5,000$ annually.

The chiller residual value after 10 years of use and needing a refurbishment will be $\$ 350,000 / 2-\$ 140,000=\$ 35,000$ or ten percent. 


\section{Solution to Class Exercise E2 \\ NIST BLCC 5.0-01: Input Data Listing \\ Consistent with Federal Life Cycle Cost Methodology and Procedures, 10 CFR, Part 436, Subpart A}

\section{General Information}

File Name:

$\mathrm{C}: \mid$ Program Files $\backslash$ BLCC5 $\backslash$ projects $\backslash$ Class Exercise

E2.xml

Run Date:

Thu Sep 20 11:34:24 EDT 2001

Analysis Type:

Project Name:

Class Exercise E2

Project Location:

Texas

Analyst:

GMM

Comment:

Base Date:

Replace Chiller or Purchase Chilled Water.

Service Date:

April 1, 2001

April 1, 2001

Study Period:

5 years 0 months (April 1, 2001 through March 31,

Discount Rate:

$6.1 \%$

Discounting Convention:

End-of-Year

Discount and Escalation Rates are NOMINAL (inclusive of general inflation)

\section{Alternative: Chiller Replacement}

\section{Energy: Electricity}

Annual Consumption: $450,000.0 \mathrm{kWh}$

Price per Unit: $\quad \$ 0.05000$

Demand Charge: $\quad \$ 5,000$

Utility Rebate: $\$ 0$

Location: U.S. Average

Rate Schedule: Industrial

State: Texas

Usage Indices

From Date Duration Usage Index

April 1, 2001 Remaining 100\%

Escalation Rates

From Date Duration Escalation

April 1, 20011 year 0 months $\quad 0.66 \%$

April 1, 20021 year 0 months $1.45 \%$

April 1, 20031 year 0 months $2.45 \%$

April 1, 20041 year 0 months $1.35 \%$

April 1, 20051 year 0 months $1.59 \%$

April 1, 20061 year 0 months $1.14 \%$

April 1, 20071 year 0 months $1.47 \%$

April 1, 20081 year 0 months $1.81 \%$ 
April 1, 20091 year 0 months

April 1, 20101 year 0 months

April 1, 20111 year 0 months

April 1, 20121 year 0 months

April 1, 20131 year 0 months

April 1, 20141 year 0 months

April 1, 20151 year 0 months

April 1, 20161 year 0 months

April 1, 20171 year 0 months

April 1, 20181 year 0 months

April 1, 20191 year 0 months

April 1, 20201 year 0 months

April 1, 20211 year 0 months

April 1, 20221 year 0 months

April 1, 20231 year 0 months

April 1, 20241 year 0 months

April 1, 20251 year 0 months

April 1, 20261 year 0 months

April 1, 20271 year 0 months

April 1, 20281 year 0 months

April 1, 20291 year 0 months

April 1, 20301 year 0 months

April 1, 2031 Remaining

$$
\begin{aligned}
& 2.34 \% \\
& 1.89 \% \\
& 1.88 \% \\
& 2.43 \% \\
& 3.07 \% \\
& 3.07 \% \\
& 3.34 \% \\
& 3.52 \% \\
& 3.51 \% \\
& 3.15 \% \\
& 3.32 \% \\
& 2.96 \% \\
& 2.96 \% \\
& 2.96 \% \\
& 2.88 \% \\
& 2.96 \% \\
& 2.96 \% \\
& 2.87 \% \\
& 2.96 \% \\
& \hline 2.96 \% \\
& 2.96 \% \\
& \hline 2.87 \% \\
& \hline 2.93 \%
\end{aligned}
$$

\section{Water: Make-up water}



(a) Summer Rates 2,100.0 ThousGal $\$ 1.000000 .0$ ThousGal $\$ 0.00000$

(a)Winter Rates $\quad 0.0$ ThousGal $\$ 0.000000 .0$ ThousGal $\$ 0.00000$

\section{Escalation Rates - Usage}

From Date Duration Usage Cost Escalation

April 1, 2001 Remaining $\quad 2.7 \%$

\section{Escalation Rates - Disposal}

From Date Duration Disposal Cost Escalation
April 1, 2001 Remaining
$2.7 \%$

Usage Indices - Usage

From Date Duration Index

April 1, 2001 Remaining 100\%

Usage Indices - Disposal

From Date Duration Index

April 1, 2001 Remaining 100\% 


\section{Component:}

\section{Initial Investment}

Initial Cost (base-year \$): $\quad \$ 350,000$

Annual Rate of Increase: $\quad 2.7 \%$

Expected Asset Life: 20 years 0 months

Residual Value Factor: $\quad 75 \%$

\section{Cost-Phasing}

Cost Adjustment Factor: 2.7\%

Years/Months (from Date) Date Portion

0 years 0 months April 1, $2001 \quad 100 \%$

\section{Recurring OM\&R: Labor}

$\begin{array}{lr}\text { Amount: } & \$ 10,000 \\ \text { Annual Rate of Increase: } & 2.7 \%\end{array}$

Usage Indices

From Date Duration Factor

April 1, 2001 Remaining 100\%

\section{Recurring OM\&R: Service Contract}

Amount: $\quad \$ 5,000$

Annual Rate of Increase: $\quad 2.7 \%$

Usage Indices

From Date Duration Factor

April 1, 2001 Remaining 100\%

\section{Alternative: Purchase Chilled water}

\section{Energy: Capacity Non-CPI}

$\begin{array}{lr}\text { Annual Consumption: } & 0.0 \mathrm{kWh} \\ \text { Price per Unit: } & \$ 0.00000 \\ \text { Demand Charge: } & \$ 14,352 \\ \text { Utility Rebate: } & \$ 0 \\ \text { Location: } & \text { U.S. Average } \\ \text { Rate Schedule: } & \text { Industrial } \\ \text { State: } & \text { Texas }\end{array}$

Usage Indices

From Date Duration Usage Index

April 1, 2001 Remaining 100\%

Escalation Rates

From Date Duration Escalation

April 1, 2001 Remaining $\quad 0 \%$ 


\section{Energy: Capacity CPI Adjusted}

$\begin{array}{lr}\text { Annual Consumption: } & 0.0 \mathrm{kWh} \\ \text { Price per Unit: } & \$ 0.00000 \\ \text { Demand Charge: } & \$ 21,528 \\ \text { Utility Rebate: } & \$ 0 \\ \text { Location: } & \text { U.S. Average } \\ \text { Rate Schedule: } & \text { Industrial } \\ \text { State: } & \text { Texas }\end{array}$

Usage Indices

From Date Duration Usage Index

April 1, 2001 Remaining $\quad 100 \%$

Escalation Rates

From Date Duration Escalation

Energy: Energy - Natural Gas Adjusted

Annual Consumption:

9,555.0 Therm

Price per Unit:

$\$ 1.00000$

Demand Charge: $\quad \$ 0$

Utility Rebate: $\quad \$ 0$

End-Use: Industrial Boiler, uncontrolled

Rate Schedule: Industrial

State: Texas

Usage Indices

From Date Duration Usage Index

April 1, 2001 Remaining 100\%

Escalation Rates

From Date Duration Escalation

April 1, 2001 Remaining 23\%

Energy: Energy - CPI Adjusted

Annual Consumption:

17,745.0 Therm

Price per Unit:

$\$ 1.00000$

Demand Charge: $\quad \$ 0$

Utility Rebate: $\quad \$ 0$

End-Use: Industrial Boiler, uncontrolled

Rate Schedule: Industrial

State: Texas

Usage Indices

From Date Duration Usage Index

April 1, 2001 Remaining $\quad 100 \%$

Escalation Rates

From Date Duration Escalation

April 1, 2001 Remaining $\quad 2.7 \%$ 


\section{Component:}

\section{Initial Investment}

Initial Cost (base-year \$): $\quad \$ 10,000$

Annual Rate of Increase: $\quad 2.7 \%$

Expected Asset Life: 20 years 0 months

Residual Value Factor: $\quad 0 \%$

\section{Cost-Phasing}

Cost Adjustment Factor: 2.7\%

Years/Months (from Date) Date Portion

0 years 0 months April 1, $2001 \quad 100 \%$ 


\section{Breakeven Analysis for Purchase Chiller versus Chilled Water}

$\begin{array}{crcc}\text { Nominal Escalation Rate } & \text { Net Savings } & \text { LCC Chiller } & \text { LCC Chilled Water } \\ 2.7 \% & \$ 32,757 & \$ 324,737 & \$ 291,980 \\ 7.7 \% & \$ 26,159 & \$ 324,737 & \$ 298,578 \\ 12.7 \% & \$ 18,684 & \$ 324,737 & \$ 306,053 \\ 17.7 \% & \$ 10,237 & \$ 324,737 & \$ 314,500 \\ 22.7 \% & \$ 717 & \$ 324,737 & \$ 324,020 \\ 27.7 \% & -\$ 9,987 & \$ 324,737 & \$ 334,724\end{array}$

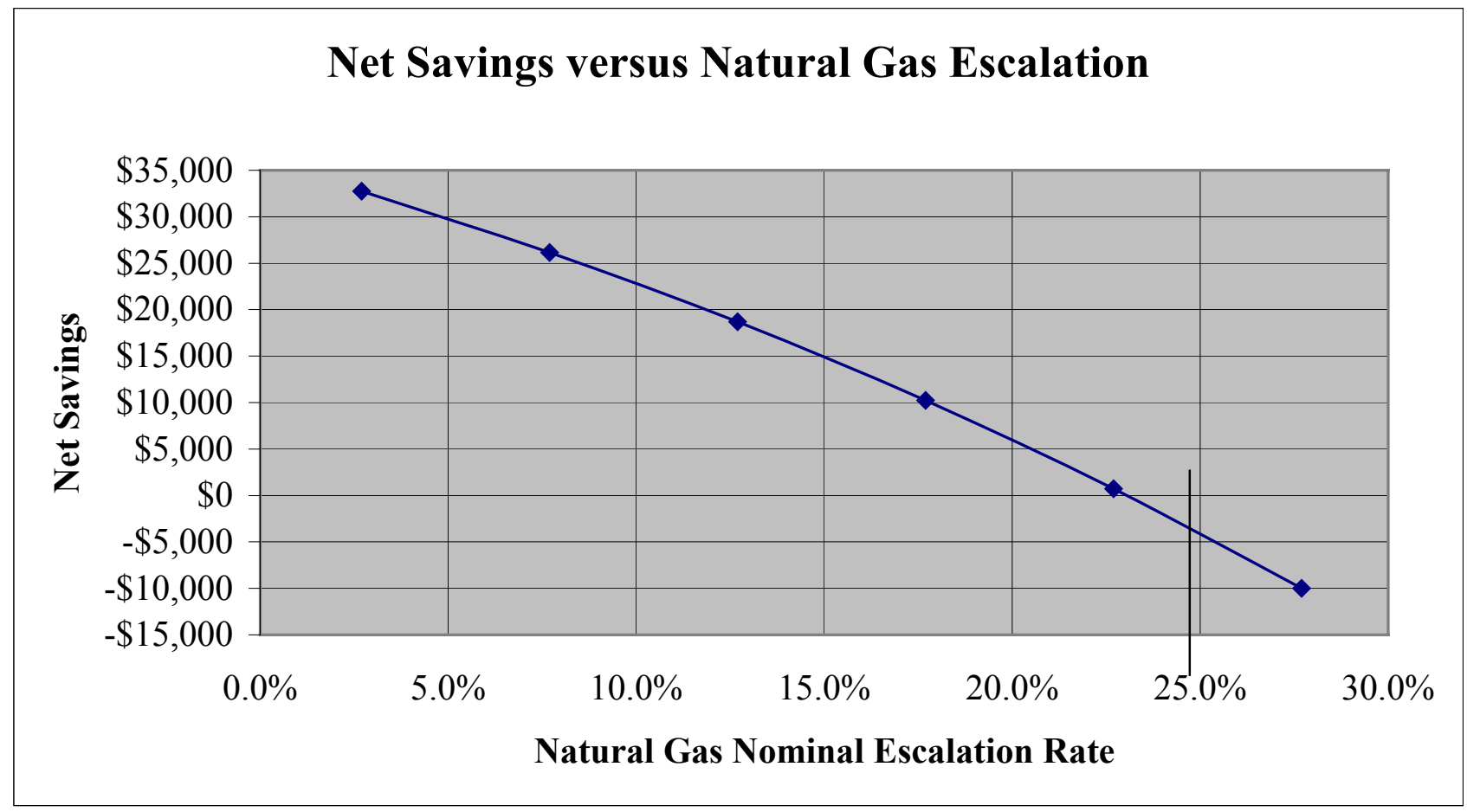

Breakeven occurs at about 23 percent nominal escalation rate. 


\section{Solution to Class Exercise E3 \\ NIST BLCC 5.0-01: Input Data Listing \\ Consistent with Federal Life Cycle Cost Methodology and Procedures, 10 CFR, Part 436, Subpart A}

\section{General Information}

File Name:

Run Date:

Analysis Type:

Project Name:

Project Location:

Analyst:

Comment:

Base Date:

Service Date:

Study Period:

Discount Rate:

Discounting Convention:
C:|Program Files $\backslash$ BLCC5 $\backslash$ projects $\backslash$ Class Exercise E3.xml

Thu Sep 20 11:51:03 EDT 2001

Federal Analysis, Agency-Funded Project

Class Exercise E3

Texas

GMM

Purchase chilled water for 10 years and then chiller versus purchase chilled water for 20

years

April 1, 2001

April 1, 2001

20 years 0 months (April 1, 2001 through March 31, 2021)

$6.1 \%$

Discount and Escalation Rates are NOMINAL (inclusive of general inflation)

\section{Alternative: Chilled water and then chiller}

Energy: Capacity - Non CPI

$\begin{array}{lr}\text { Annual Consumption: } & 0.0 \mathrm{kWh} \\ \text { Price per Unit: } & \$ 0.00000 \\ \text { Demand Charge: } & \$ 14,352 \\ \text { Utility Rebate: } & \$ 0 \\ \text { End-Use: } & \text { Industrial Boiler, uncontrolled } \\ \text { Rate Schedule: } & \text { Industrial } \\ \text { State: } & \text { Texas }\end{array}$

Usage Indices

From Date Duration Usage Index

April 1, 200110 years 0 months $\quad 100 \%$

April 1, 2011 Remaining $\quad 0 \%$

Escalation Rates

From Date Duration Escalation

April 1, 2001 Remaining $\quad 0 \%$

Energy: Natural Gas

Annual Consumption:

9,555.0 Therm

Price per Unit:

$\$ 1.00000$

Demand Charge: $\quad \$ 0$

Utility Rebate:

$\$ 0$

End-Use:

Industrial Boiler, uncontrolled 


\section{Usage Indices}

From Date Duration Usage Index

April 1, 200110 years 0 months $\quad$ 100\%

April 1, 2011 Remaining $0 \%$

\section{Escalation Rates}

\section{From Date Duration Escalation}

April 1, 20011 year 0 months $\quad-8.86 \%$

April 1, 20021 year 0 months $\quad-7.90 \%$

April 1, 20031 year 0 months $\quad-2.37 \%$

April 1, 20041 year 0 months $\quad 3.06 \%$

April 1, 20051 year 0 months $\quad 4.12 \%$

April 1, 20061 year 0 months $\quad 4.45 \%$

April 1, 20071 year 0 months $\quad 4.42 \%$

April 1, 20081 year 0 months $\quad 3.38 \%$

April 1, 20091 year 0 months $\quad 3.71 \%$

April 1, 20101 year 0 months $\quad 3.36 \%$

April 1, 20111 year 0 months $\quad 3.36 \%$

April 1, 20121 year 0 months $\quad 4.01 \%$

April 1, 20131 year 0 months $\quad 3.67 \%$

April 1, 20141 year 0 months $\quad 4.30 \%$

April 1, 20151 year 0 months $\quad 4.28 \%$

April 1, 20161 year 0 months $\quad 4.57 \%$

April 1, 20171 year 0 months $\quad 4.53 \%$

April 1, 20181 year 0 months $\quad 4.80 \%$

April 1, 20191 year 0 months $\quad 5.35 \%$

April 1, 20201 year 0 months $\quad 4.42 \%$

April 1, 20211 year 0 months $\quad 4.11 \%$

April 1, 20221 year 0 months $\quad 3.81 \%$

April 1, 20231 year 0 months $\quad 4.08 \%$

April 1, 20241 year 0 months $\quad 4.06 \%$

April 1, 20251 year 0 months $\quad 4.04 \%$

April 1, 20261 year 0 months $\quad 4.02 \%$

April 1, 20271 year 0 months $\quad 4.01 \%$

April 1, 20281 year 0 months $\quad 3.99 \%$

April 1, 20291 year 0 months $\quad 4.23 \%$

April 1, 20301 year 0 months $\quad 3.96 \%$

April 1, 2031 Remaining $\quad 4.04 \%$

\section{Energy: Capacity - CPI adjusted}

Annual Consumption:

Price per Unit:

Demand Charge:

Utility Rebate:

End-Use:
$0.0 \mathrm{kWh}$

$\$ 0.00000$

$\$ 21,528$

$\$ 0$

Industrial Boiler, uncontrolled 
Rate Schedule:

Industrial

State:

Texas

Usage Indices

From Date Duration Usage Index

April 1, 200110 years 0 months $\quad$ 100\%

April 1, 2011 Remaining $\quad 0 \%$

\section{Escalation Rates}

From Date Duration Escalation

April 1, 2001 Remaining $\quad 2.7 \%$

Energy: Energy - CPI adjusted

$\begin{array}{lr}\text { Annual Consumption: } & 17,745.0 \text { Therm } \\ \text { Price per Unit: } & \$ 1.00000 \\ \text { Demand Charge: } & \$ 0 \\ \text { Utility Rebate: } & \$ 0 \\ \text { End-Use: } & \text { Industrial Boiler, uncontrolled } \\ \text { Rate Schedule: } & \text { Industrial } \\ \text { State: } & \text { Texas }\end{array}$

Usage Indices

From Date Duration Usage Index

April 1, 200110 years 0 months $\quad$ 100\%

April 1, 2011 Remaining $\quad 0 \%$

Escalation Rates

From Date Duration Escalation

April 1, 2001 Remaining $\quad 2.7 \%$

\section{Energy: Electricity}

Annual Consumption: $450,000.0 \mathrm{kWh}$

Price per Unit: $\quad \$ 0.05000$

Demand Charge: $\quad \$ 5,000$

Utility Rebate: $\quad \$ 0$

Location: U.S. Average

Rate Schedule: Industrial

State: Texas

Usage Indices

From Date Duration Usage Index

April 1, 200110 years 0 months $\quad 0 \%$

April 1, 2011 Remaining 100\%

\section{Escalation Rates}

From Date Duration Escalation

April 1, 20011 year 0 months $\quad 0.66 \%$

April 1, 20021 year 0 months $1.45 \%$

April 1, 20031 year 0 months $\quad 2.45 \%$ 
April 1, 20041 year 0 months

April 1, 20051 year 0 months

April 1, 20061 year 0 months

April 1, 20071 year 0 months

April 1, 20081 year 0 months

April 1, 20091 year 0 months

April 1, 20101 year 0 months

April 1, 20111 year 0 months

April 1, 20121 year 0 months

April 1, 20131 year 0 months

April 1, 20141 year 0 months

April 1, 20151 year 0 months

April 1, 20161 year 0 months

April 1, 20171 year 0 months

April 1, 20181 year 0 months

April 1, 20191 year 0 months

April 1, 20201 year 0 months

April 1, 20211 year 0 months

April 1, 20221 year 0 months

April 1, 20231 year 0 months

April 1, 20241 year 0 months

April 1, 20251 year 0 months

April 1, 20261 year 0 months

April 1, 20271 year 0 months

April 1, 20281 year 0 months

April 1, 20291 year 0 months

April 1, 20301 year 0 months

April 1, 2031 Remaining
$1.35 \%$

$1.59 \%$

$1.14 \%$

$1.47 \%$

$1.81 \%$

$2.34 \%$

$1.89 \%$

$1.88 \%$

$2.43 \%$

$3.07 \%$

$3.07 \%$

$3.34 \%$

$3.52 \%$

$3.51 \%$

$3.15 \%$

$3.32 \%$

$2.96 \%$

$2.96 \%$

$2.96 \%$

$2.88 \%$

$2.96 \%$

$2.96 \%$

$2.87 \%$

$2.96 \%$

$2.96 \%$

$2.96 \%$

$2.87 \%$

$2.93 \%$

Water: Make-up water

Annual Usage Annual Disposal

Units/Year Price/Unit Units/Year Price/Unit

@Summer Rates $\quad 2,100.0 \mathrm{~L} \quad \$ 1.00000 \quad 0.0 \mathrm{~L} \quad \$ 0.00000$

$\begin{array}{lllll}\text { aWinter Rates } & 0.0 \mathrm{~L} & \$ 0.00000 & 0.0 \mathrm{~L} & \$ 0.00000\end{array}$

Escalation Rates - Usage

From Date Duration Usage Cost Escalation

April 1, 2001 Remaining $\quad 2.7 \%$

Escalation Rates - Disposal

From Date Duration Disposal Cost Escalation

April 1, 2001 Remaining

$2.7 \%$

Usage Indices - Usage

From Date Duration Index

April 1, 200110 years 0 months $\quad 0 \%$

April 1, $2011 \quad$ Remaining $\quad 100 \%$ 
Usage Indices - Disposal

From Date Duration Index

April 1, 2001 Remaining 100\%

\section{Component: Purchase chilled water for 10 years}

\section{Initial Investment}

Initial Cost (base-year \$): $\quad \$ 10,000$

Annual Rate of Increase: $\quad 2.7 \%$

Expected Asset Life: 1 year 0 months

Residual Value Factor: $\quad 0 \%$

Cost-Phasing

Cost Adjustment Factor: $2.7 \%$

Years/Months (from Date) Date Portion

0 years 0 months April 1, $2001 \quad 100 \%$

\section{Component: Purchase Chiller}

\section{Initial Investment}

Initial Cost (base-year \$): $\quad \$ 350,000$

Annual Rate of Increase: $\quad 2.7 \%$

Expected Asset Life: $\quad 20$ years 0 months

Residual Value Factor: $\quad 10 \%$

Cost-Phasing

Cost Adjustment Factor: 2.7\%

Years/Months (from Date) Date Portion

10 years 0 months $\quad$ April 1, $2011 \quad 100 \%$

Recurring OM\&R: In-house labor

Amount: $\quad \$ 10,000$

Annual Rate of Increase: $\quad 2.7 \%$

Usage Indices

From Date Duration Factor

April 1, 200110 years 0 months $\quad 0 \%$

April 1, $2011 \quad$ Remaining $\quad 100 \%$

Recurring OM\&R: Service contract

Amount: $\quad \$ 5,000$

Annual Rate of Increase： $2.7 \%$

Usage Indices

From Date Duration Factor

April 1, 200110 years 0 months $\quad 0 \%$

April 1, $2011 \quad$ Remaining $\quad 100 \%$ 


\section{Alternative: 20 Year Chilled Water}

\section{Energy: Copy of: Capacity - Non CPI}

Annual Consumption:

Price per Unit:

Demand Charge:

Utility Rebate:

End-Use:

Rate Schedule:

State:

\section{Usage Indices}

From Date Duration Usage Index

April 1, 200120 years 0 months $\quad 100 \%$

April 1, $2021 \quad$ Remaining 100\%

\section{Escalation Rates}

From Date Duration Escalation

April 1, 2001 Remaining $\quad 0 \%$

\section{Energy: Copy of: Natural Gas}

$\begin{array}{lr}\text { Annual Consumption: } & 9,555.0 \text { Therm } \\ \text { Price per Unit: } & \$ 1.00000 \\ \text { Demand Charge: } & \$ 0 \\ \text { Utility Rebate: } & \$ 0 \\ \text { End-Use: } & \text { Industrial Boiler, uncontrolled } \\ \text { Rate Schedule: } & \text { Industrial } \\ \text { State: } & \text { Texas }\end{array}$

\section{Usage Indices}

From Date Duration Usage Index

April 1, 200120 years 0 months $\quad 100 \%$

April 1, 2021 Remaining 100\%

\section{Escalation Rates}

\begin{tabular}{|c|c|}
\hline on & nn \\
\hline pril 1, 20011 year 0 months & $-\varepsilon$ \\
\hline pril 1, 20021 year 0 months & $-7.90 \%$ \\
\hline pril 1, 20031 year 0 months & $-2.37^{\circ}$ \\
\hline 1,20041 year 0 & $3.06 \%$ \\
\hline 1,20051 year 0 mo & 4.12 \\
\hline 1, 20061 year 0 mon & $4.45 \%$ \\
\hline 20071 year & 4.4 \\
\hline 1, 20081 year 0 mon & 3.3 \\
\hline , 20091 year 0 months & 3.71 \\
\hline 1, 20101 year 0 mor & 3.3 \\
\hline , 20111 year 0 mon & 3.36 \\
\hline $20121 \mathrm{y}$ & 4.0 \\
\hline
\end{tabular}

$0.0 \mathrm{kWh}$

$\$ 0.00000$

$\$ 14,352$

$\$ 0$

Industrial

Texas 


\begin{tabular}{|c|c|}
\hline April 1, 20131 year 0 months & $3.67 \%$ \\
\hline April 1, 20141 year 0 months & $4.30 \%$ \\
\hline April 1, 20151 year 0 months & $4.28 \%$ \\
\hline April 1, 20161 year 0 months & $4.57 \%$ \\
\hline April 1, 20171 year 0 months & $4.53 \%$ \\
\hline April 1, 20181 year 0 months & $4.80 \%$ \\
\hline April 1, 20191 year 0 months & $5.35 \%$ \\
\hline April 1, 20201 year 0 months & $4.42 \%$ \\
\hline April 1, 20211 year 0 months & $4.11 \%$ \\
\hline April 1, 20221 year 0 months & $3.81 \%$ \\
\hline April 1, 20231 year 0 months & $4.08 \%$ \\
\hline April 1, 20241 year 0 months & $4.06 \%$ \\
\hline April 1, 20251 year 0 months & $4.04 \%$ \\
\hline April 1, 20261 year 0 months & $4.02 \%$ \\
\hline April 1, 20271 year 0 months & $4.01 \%$ \\
\hline April 1, 20281 year 0 months & $3.99 \%$ \\
\hline April 1, 20291 year 0 months & $4.23 \%$ \\
\hline April 1, 20301 year 0 months & $3.96 \%$ \\
\hline April 1, $2031 \quad$ Remaining & $4.04 \%$ \\
\hline
\end{tabular}

\section{Energy: Copy of: Capacity - CPI adjusted}

$\begin{array}{lr}\text { Annual Consumption: } & 0.0 \mathrm{kWh} \\ \text { Price per Unit: } & \$ 0.00000 \\ \text { Demand Charge: } & \$ 21,528 \\ \text { Utility Rebate: } & \$ 0 \\ \text { End-Use: } & \text { Industrial Boiler, uncontrolled } \\ \text { Rate Schedule: } & \text { Industrial } \\ \text { State: } & \text { Texas }\end{array}$

\section{Usage Indices}

From Date Duration Usage Index

April 1, 200120 years 0 months $\quad 100 \%$

April 1, $2021 \quad$ Remaining 100\%

\section{Escalation Rates}

From Date Duration Escalation

April 1, 2001 Remaining $\quad 2.7 \%$

\section{Energy: Copy of: Energy - CPI adjusted}

Annual Consumption: $\quad 17,745.0$ Therm

Price per Unit: $\quad \$ 1.00000$

Demand Charge: $\quad \$ 0$

Utility Rebate: $\quad \$ 0$

End-Use: Industrial Boiler, uncontrolled

Rate Schedule: Industrial

State: Texas

\section{Usage Indices}

From Date Duration Usage Index 
April 1, 200120 years 0 months $\quad$ 100\%

April 1, 2021 Remaining 100\%

Escalation Rates

From Date Duration Escalation

April 1, 2001 Remaining $\quad 2.7 \%$

\section{Component: Copy of: Purchase chilled water for 10 years}

\section{Initial Investment}

Initial Cost (base-year \$): $\quad \$ 10,000$

Annual Rate of Increase: $\quad 2.7 \%$

Expected Asset Life: 1 year 0 months

Residual Value Factor: $\quad 0 \%$

Cost-Phasing

Cost Adjustment Factor: $2.7 \%$

Years/Months (from Date) Date Portion

0 years 0 months April 1, $2001 \quad 100 \%$ 


\section{NIST BLCC 5.0-01: Detailed LCC Analysis}

Consistent with Federal Life Cycle Cost Methodology and Procedures, 10 CFR, Part 436, Subpart A

\section{General Information}

File Name:

Run Date:

Analysis Type:

Project Name:

Project Location:

Analyst:

Comment:

Base Date:

Service Date:

Study Period:

Discount Rate:

Discounting Convention:
C:|Program Files $\backslash$ BLCC5 $\backslash$ projects $\backslash$ Class Exercise E3.xml

Thu Sep 20 13:25:39 EDT 2001

Federal Analysis, Agency-Funded Project

Class Exercise E3

Texas

GMM

Purchase chilled water for 10 years and then chiller versus purchase chilled water for 20

years

April 1, 2001

April 1, 2001

20 years 0 months (April 1, 2001 through March 31, 2021)

$6.1 \%$

Discount and Escalation Rates are NOMINAL (inclusive of general inflation)

\section{Alternative: Chilled water and then chiller \\ Initial Cost Data (not Discounted)}

\section{Initial Capital Costs}

(adjusted for price escalation)

Initial Capital Costs for All Components: $\$ 466,832$

Component: Purchase chilled water for 10 years

Cost-Phasing

Date Portion Yearly Cost

April 1, 2001

$100 \% \$ \$ 10,000$

Total (for Component)

$\$ 10,000$

Component: Purchase Chiller

Cost-Phasing

Date

April 1, 2011

Portion Yearly Cost

$100 \% \$ 456,832$

Total (for Component)

$\$ 456,832$

Energy Costs: Capacity - Non CPI

(base-year dollars)
Average
Average
Average
Average

Annual Usage Price/Unit Annual Cost Annual Demand Annual Rebate
$0.0 \mathrm{kWh} \quad \$ 0.00000$
$\$ 0$
$\$ 7,176$
$\$ 0$ 
Energy Costs: Natural Gas

(base-year dollars)

Average Average Average Average

Annual Usage Price/Unit Annual Cost Annual Demand Annual Rebate

$\begin{array}{lllll}4,777.5 & \text { Therm } & \$ 1.00000 & \$ 4,778 & \$ 0\end{array}$

Energy Costs: Capacity - CPI adjusted

(base-year dollars)

Average Average Average Average

Annual Usage Price/Unit Annual Cost Annual Demand Annual Rebate
$0.0 \mathrm{kWh} \$ 0.00000$
$\$ 0$
$\$ 10,764$
$\$ 0$

Energy Costs: Energy - CPI adjusted

(base-year dollars)

Average Average Average Average

Annual Usage Price/Unit Annual Cost Annual Demand Annual Rebate

$\begin{array}{lllll}8,872.5 & \text { Therm } & \$ 1.00000 & \$ 8,872 & \$ 0\end{array}$

Energy Costs: Electricity

(base-year dollars)

Average Average Average Average

Annual Usage Price/Unit Annual Cost Annual Demand Annual Rebate
$225,000.0 \mathrm{kWh} \$ 0.05000$
$\$ 11,250$
$\$ 2,500$
$\$ 0$

Water Costs: Make-up water

(base-year dollars)

Average Annual Usage Average Annual Disposal Average Annual

\begin{tabular}{lrrrrr} 
Water & Units/Year & Price/Unit & Units/Year & Price/Unit & \multicolumn{1}{c}{ Cost } \\
(a) Summer Rates & $1,050.0 \mathrm{~L}$ & $\$ 1.00000$ & $0.0 \mathrm{~L}$ & $\$ 0.00000$ & $\$ 1,050$ \\
(a) Winter Rates & $0.0 \mathrm{~L}$ & $\$ 0.00000$ & $0.0 \mathrm{~L}$ & $\$ 0.00000$ & $\$ 0$
\end{tabular}

\section{Life-Cycle Cost Analysis}

Initial Capital Costs

Energy Costs

Energy Consumption Costs

Energy Demand Charges

Energy Utility Rebates

Subtotal (for Energy):

Water Usage Costs

Water Disposal Costs
Present Value Annual Value

$$
\$ 262,979 \quad \$ 23,095
$$

$\begin{array}{rr}\$ 336,857 & \$ 29,584 \\ \$ 313,579 & \$ 27,539 \\ \$ 0 & \$ 0 \\ ------ & -------- \\ \$ 650,437 & \$ 57,123\end{array}$

$\begin{array}{rr}\$ 12,753 & \$ 1,120 \\ \$ 0 & \$ 0\end{array}$

Operating, Maintenance \& Repair Costs 
Component: Purchase chilled water for 10 years

Annually Recurring Costs

Non-Annually Recurring Costs

Component: Purchase Chiller

Annually Recurring Costs

Non-Annually Recurring Costs

Subtotal (for OM\&R):

Replacements to Capital Components

Component: Purchase chilled water for 10 years

Component: Purchase Chiller

Subtotal (for Replacements):

Residual Value of Original Capital Components

Component: Purchase chilled water for 10 years

Component: Purchase Chiller

Subtotal (for Residual Value):

Residual Value of Capital Replacements

Component: Purchase chilled water for 10 years

Component: Purchase Chiller

Subtotal (for Residual Value):

Total Life-Cycle Cost

\section{Emissions Summary}

Energy Name

Capacity - Non CPI:

$\mathrm{CO} 2$

SO2

NOx
Annual

$$
\begin{aligned}
& 0.00 \mathrm{~kg} \\
& 0.00 \mathrm{~kg} \\
& 0.00 \mathrm{~kg}
\end{aligned}
$$

$\$ 0$

$\$ 0$

$\begin{array}{rr}\$ 91,089 & \$ 8,000 \\ \$ 0 & \$ 0 \\ ------- & ------ \\ \$ 91,089 & \$ 8,000\end{array}$

Natural Gas:

$\begin{array}{lrr}\text { CO2 } & 25,236.45 \mathrm{~kg} & 504,659.81 \mathrm{~kg} \\ \text { SO2 } & 203.67 \mathrm{~kg} & 4,072.76 \mathrm{~kg} \\ \text { NOx } & 29.74 \mathrm{~kg} & 594.78 \mathrm{~kg}\end{array}$

Capacity - CPI adjusted:

$\begin{array}{lll}\text { CO2 } & 0.00 \mathrm{~kg} & 0.00 \mathrm{~kg} \\ \text { SO2 } & 0.00 \mathrm{~kg} & 0.00 \mathrm{~kg} \\ \text { NOx } & 0.00 \mathrm{~kg} & 0.00 \mathrm{~kg}\end{array}$

Energy - CPI adjusted:

$\mathrm{CO} 2$

$46,867.68 \mathrm{~kg} \quad 937,225.37 \mathrm{~kg}$ 


$\begin{array}{lrr}\text { SO2 } & 378.24 \mathrm{~kg} & 7,563.70 \mathrm{~kg} \\ \text { NOx } & 55.24 \mathrm{~kg} & 1,104.60 \mathrm{~kg}\end{array}$

Electricity:

$\begin{array}{lrr}\text { CO2 } & 218,094.01 \mathrm{~kg} & 4,361,283.00 \mathrm{~kg} \\ \text { SO2 } & 664.29 \mathrm{~kg} & 13,284.00 \mathrm{~kg} \\ \text { NOx } & 657.00 \mathrm{~kg} & 13,138.20 \mathrm{~kg}\end{array}$

Total:

$\begin{array}{lrr}\text { CO2 } & 290,198.14 \mathrm{~kg} & 5,803,168.18 \mathrm{~kg} \\ \text { SO2 } & 1,246.19 \mathrm{~kg} & 24,920.47 \mathrm{~kg} \\ \text { NOx } & 741.98 \mathrm{~kg} & 14,837.59 \mathrm{~kg}\end{array}$

\section{Alternative: 20 Year Chilled Water}

\section{Initial Cost Data (not Discounted)}

\section{Initial Capital Costs}

(adjusted for price escalation)

Initial Capital Costs for All Components: $\$ 10,000$

Component: Copy of: Purchase chilled water for 10 years

Cost-Phasing

Date

April 1, 2001

Portion Yearly Cost

$100 \% \quad \$ 10,000$

Total (for Component)

$\$ 10,000$

Energy Costs: Copy of: Capacity - Non CPI (base-year dollars)

Average Average Average Average

Annual Usage Price/Unit Annual Cost Annual Demand Annual Rebate $\begin{array}{llll}0.0 \mathrm{kWh} & \$ 0.00000 & \$ 0 & \$ 14,352\end{array}$

Energy Costs: Copy of: Natural Gas

(base-year dollars)

Average Average Average Average

Annual Usage Price/Unit Annual Cost Annual Demand Annual Rebate

9,555.0 Therm $\$ 1.00000 \quad \$ 9,555 \quad \$ 0 \quad \$ 0$

Energy Costs: Copy of: Capacity - CPI adjusted (base-year dollars)

Average Average Average Average

Annual Usage Price/Unit Annual Cost Annual Demand Annual Rebate $\begin{array}{lllll}0.0 \mathrm{kWh} & \$ 0.00000 & \$ 0 & \$ 21,528 & \$ 0\end{array}$

Energy Costs: Copy of: Energy - CPI adjusted (base-year dollars)
Average
Average
Average
Average

Annual Usage Price/Unit Annual Cost Annual Demand Annual Rebate 
$\begin{array}{lllll}17,745.0 \text { Therm } & \$ 1.00000 & \$ 17,745 & \$ 0 & \$ 0\end{array}$

\section{Life-Cycle Cost Analysis}

Initial Capital Costs

Energy Costs

Energy Consumption Costs

Energy Demand Charges

Energy Utility Rebates

Subtotal (for Energy):

Water Usage Costs

Water Disposal Costs

Operating, Maintenance \& Repair Costs

Component: Copy of: Purchase chilled water for 10 years Annually Recurring Costs

Non-Annually Recurring Costs

Subtotal (for OM\&R):

Replacements to Capital Components

Component: Copy of: Purchase chilled water for 10 years

Subtotal (for Replacements):

Residual Value of Original Capital Components

Component: Copy of: Purchase chilled water for 10 years

Subtotal (for Residual Value):

Residual Value of Capital Replacements

Component: Copy of: Purchase chilled water for 10 years

Subtotal (for Residual Value):

Total Life-Cycle Cost
Present Value Annual Value

$\$ 10,000$

$\$ 878$

$\begin{array}{rr}\$ 371,605 & \$ 32,635 \\ \$ 475,072 & \$ 41,722 \\ \$ 0 & \$ 0\end{array}$

$\$ 0 \quad \$ 0$

$\$ 0 \quad \$ 0$
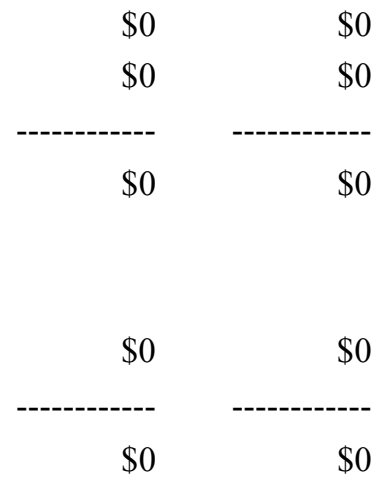

$\$ 0$

$\$ 0$

$\$ 0$

$\$ 0$

$\$ 0$

$\$ 0$

$\$ 0$

$\$ 0$

$\$ 856,676 \quad \$ 75,235$ 


\section{Emissions Summary}

Energy Name

Copy of: Capacity - Non CPI:

$\mathrm{CO} 2$
$\mathrm{SO} 2$
$\mathrm{NOx}$

Copy of: Natural Gas:

$\mathrm{CO} 2$
$\mathrm{SO} 2$

NOx

Copy of: Capacity - CPI adjusted:

$\mathrm{CO} 2$
$\mathrm{SO} 2$
NOx

Copy of: Energy - CPI adjusted:

$\begin{array}{lrr}\text { CO2 } & 93,735.37 \mathrm{~kg} & 1,874,450.74 \mathrm{~kg} \\ \text { SO2 } & 756.47 \mathrm{~kg} & 15,127.41 \mathrm{~kg} \\ \text { NOx } & 110.48 \mathrm{~kg} & 2,209.20 \mathrm{~kg}\end{array}$

Total:

\section{Annual Life-Cycle}

$\begin{array}{ll}0.00 \mathrm{~kg} & 0.00 \mathrm{~kg} \\ 0.00 \mathrm{~kg} & 0.00 \mathrm{~kg} \\ 0.00 \mathrm{~kg} & 0.00 \mathrm{~kg}\end{array}$

$\begin{array}{rr}50,472.89 \mathrm{~kg} & 1,009,319.63 \mathrm{~kg} \\ 407.33 \mathrm{~kg} & 8,145.53 \mathrm{~kg} \\ 59.49 \mathrm{~kg} & 1,189.57 \mathrm{~kg}\end{array}$

$\begin{array}{ll}0.00 \mathrm{~kg} & 0.00 \mathrm{~kg} \\ 0.00 \mathrm{~kg} & 0.00 \mathrm{~kg} \\ 0.00 \mathrm{~kg} & 0.00 \mathrm{~kg}\end{array}$

$93,735.37 \mathrm{~kg} 1,874,450.74 \mathrm{~kg}$

$144,208.26 \mathrm{~kg} \mathrm{2,883,770.36 \textrm {kg }}$

$1,163.81 \mathrm{~kg} \quad 23,272.94 \mathrm{~kg}$

$169.96 \mathrm{~kg} \quad 3,398.77 \mathrm{~kg}$ 


\section{NIST BLCC 5.0-01: Comparative Analysis}

Consistent with Federal Life Cycle Cost Methodology and Procedures, 10 CFR, Part 436, Subpart A

\section{Base Case: Chilled water and then chiller}

Alternative: 20 Year Chilled Water

\section{General Information}

File Name:

Run Date:

Project Name:

Project Location:

Analysis Type:

Analyst:

Comment

Base Date of Study:

Service Date:

Study Period:

Discount Rate:

Discounting Convention:
C: Program Files $\backslash$ BLCC5 $\backslash$ projects $\backslash$ Class Exercise E3.xml

Thu Sep 20 11:54:01 EDT 2001

Class Exercise E3

Texas

Federal Analysis, Agency-Funded Project

GMM

Purchase chilled water for 10 years and then chiller versus purchase chilled water for 20 years

April 1, 2001

April 1, 2001

20 years 0 months(April 1, 2001 through March 31, 2021)

$6.1 \%$

End-of-Year

\section{Comparison of Present-Value Costs}

\section{PV Life-Cycle Cost}

Base Case Alternative Savings from Alternative

Initial Investment Costs:

Capital Requirements as of Base Date

$\$ 262,979$

$\$ 10,000$

$\$ 252,979$

Future Costs:

Energy Consumption Costs

$\$ 336,857 \$ 371,605$

$\$ 313,579 \$ 475,072$

$-\$ 34,747$

Energy Demand Charges

$\$ 0$

$\$ 0$

$-\$ 161,492$

Energy Utility Rebates

$\$ 12,753$

$\$ 0$

$\$ 0$

Water Costs

$\$ 91,089$

$\$ 0$

$\$ 12,753$

Recurring and Non-Recurring OM\&R Costs

$\$ 0$

$\$ 0$

$\$ 91,089$

Capital Replacements

$-\$ 18,285$

$\$ 0$

$\$ 0$

Residual Value at End of Study Period

$\$ 735,993$

Subtotal (for Future Cost Items)

$\$ 735,993$

$\$ 846,676$

$-\$ 110,683$

Total PV Life-Cycle Cost

$\$ 998,972 \quad \$ 856,676$

$\$ 142,296$

\section{Net Savings from Alternative Compared with Base Case}

PV of Non-Investment Savings - $\$ 92,398$

- Increased Total Investment $\quad$-\$234,694 


\section{Savings-to-Investment Ratio (SIR)}

$\mathbf{S I R}=0.39$

SIR is lower than 1.0; project alternative is not cost effective.

\section{Adjusted Internal Rate of Return}

$\operatorname{AIRR}=1.26 \%$

AIRR is lower than your discount rate; project alternative is not cost effective.

\section{Payback Period}

Estimated Years to Payback (from beginning of Service Period)

Simple Payback occurs in year 1

Discounted Payback occurs in year 1

\section{Energy Savings Summary}

\section{Energy Savings Summary (in stated units)}

Units for every energy type not the same, can't report energy savings

\section{Energy Savings Summary (in MBtu)}

\begin{tabular}{lcccc} 
Energy & -----Average & \multicolumn{1}{c}{ Annual } & Consumption----- & \multicolumn{1}{c}{ Life-Cycle } \\
Type & Base Case & Alternative & \multicolumn{1}{c}{ Savings } & \multicolumn{1}{c}{ Savings } \\
Electricity & $767.7 \mathrm{MBtu}$ & $0.0 \mathrm{MBtu}$ & $767.7 \mathrm{MBtu}$ & $15,352.5 \mathrm{MBtu}$ \\
Natural Gas & $1,365.0 \mathrm{MBtu}$ & $2,730.0 \mathrm{MBtu}$ & $-1,365.0 \mathrm{MBtu}$ & $-27,296.4 \mathrm{MBtu}$
\end{tabular}

\section{Emissions Reduction Summary}

\begin{tabular}{|c|c|c|c|c|}
\hline $\begin{array}{l}\text { Energy } \\
\text { Type }\end{array}$ & $\begin{array}{l}\text {----Average } \\
\text { Base Case }\end{array}$ & $\begin{array}{c}\text { Annual } \\
\text { Alternative }\end{array}$ & $\begin{array}{c}\text { Emissions----- } \\
\text { Reduction }\end{array}$ & $\begin{array}{l}\text { Life-Cycle } \\
\text { Reduction }\end{array}$ \\
\hline \multicolumn{5}{|l|}{ Electricity } \\
\hline $\mathrm{CO} 2$ & $218,094.01 \mathrm{~kg}$ & $0.00 \mathrm{~kg}$ & $218,094.01 \mathrm{~kg}$ & $4,361,283.00 \mathrm{~kg}$ \\
\hline $\mathrm{SO} 2$ & $664.29 \mathrm{~kg}$ & $0.00 \mathrm{~kg}$ & $664.29 \mathrm{~kg}$ & $13,284.00 \mathrm{~kg}$ \\
\hline NOx & $657.00 \mathrm{~kg}$ & $0.00 \mathrm{~kg}$ & $657.00 \mathrm{~kg}$ & $13,138.20 \mathrm{~kg}$ \\
\hline \multicolumn{5}{|c|}{ Natural Gas } \\
\hline $\mathrm{CO} 2$ & $72,104.13 \mathrm{~kg}$ & $144,208.26 \mathrm{~kg}$ & $-72,104.13 \mathrm{~kg}$ & $-1,441,885.18 \mathrm{~kg}$ \\
\hline $\mathrm{SO} 2$ & $581.90 \mathrm{~kg}$ & $1,163.81 \mathrm{~kg}$ & $-581.90 \mathrm{~kg}$ & $-11,636.47 \mathrm{~kg}$ \\
\hline NOx & $84.98 \mathrm{~kg}$ & $169.96 \mathrm{~kg}$ & $-84.98 \mathrm{~kg}$ & $-1,699.39 \mathrm{~kg}$ \\
\hline \multicolumn{5}{|l|}{ Total: } \\
\hline $\mathrm{CO} 2$ & $290,198.14 \mathrm{~kg}$ & $144,208.26 \mathrm{~kg}$ & $145,989.88 \mathrm{~kg}$ & $2,919,397.82 \mathrm{~kg}$ \\
\hline $\mathrm{SO} 2$ & $1,246.19 \mathrm{~kg}$ & $1,163.81 \mathrm{~kg}$ & $82.39 \mathrm{~kg}$ & $1,647.53 \mathrm{~kg}$ \\
\hline NOx & $741.98 \mathrm{~kg}$ & $169.96 \mathrm{~kg}$ & $572.02 \mathrm{~kg}$ & $11,438.81 \mathrm{~kg}$ \\
\hline
\end{tabular}





\section{Module F}

\section{Evaluation of Alternative Financing Contracts}

Objectives: Upon completion of this module, you will

know how to

- structure alternative financing (AF) projects

for LCCA.

- Energy Savings Performance Contracts (ESPCs)

- Utility Energy Services Contracts (UCs)

- use BLCC5 to perform the analysis. 


\section{Steps in LCCA of AF Contracts}

- Select the systems and equipment to impact and at what level.

- Perform LCCAs for individual ECMs.

- Determine which ECMs to bundle.

- Evaluate project for cost-effectiveness compared with status quo or other strategies. 


\section{Typical AF Costs and Benefits}

- Acquisition and debt service

- Principal

- Interest

- Performance Period Expenses

- Management and administration

- Measurement and verification

- Overhead and profit

- O\&M *

- Repair and replacement*

- Down payment

- Energy costs

* Capitalization of traditional operating expenses blurs the lines between investment and operational costs. 


\section{Bundling of ECMs}

- Bundling of independent projects

- Each individual project should be cost-effective.

- EO 13123 allows bundling of non-cost-effective ECMs with those that generate high NS.

- Bundling does not guarantee maximization of NS for government investments overall.

- Bundling of interdependent projects

- Analysts must account for interaction among systems.

- Energy consumption of different combinations needs to be recalculated. 


\section{Exercise F1}

Evaluation of ESPC Contract

\section{PROBLEM STATEMENT}

The building manager of the Jefferson Training Facility in Tennessee has been investigating the possibility of financing, through an Energy Savings Performance Contract, an upgrade of the facility's hot water system and other energy conservation measures. In collaboration with an ESCO, she has identified five retrofit measures, which, according to the ESCO proposal, would result in operational cost savings of approximately $\$ 120 \mathrm{~K}$ annually. With the current maintenance and repair schedule, the existing system could be kept functional for another 25 years.

\section{Options}

\section{Maintain status quo with current maintenance and repair schedule.}

\section{Install the following Energy Conservation Measures (ECMs:}

1. Install new natural gas hot water boilers $(\$ 262,500)$.

2. Convert existing, electric DHW heating system to natural gas DHW system $(\$ 50,000)$.

3. Install campus-wide direct digital control (DDC) system $(\$ 412,500)$.

4. Improve lighting system $(\$ 250,000)$.

5. Convert constant HW and CW loops to variable flow $(\$ 187,500)$. 


\section{Exercise F1 (cont.)}

\section{ANALYSIS}

Perform an LCC analysis to determine whether the project would be life-cycle cost-effective if it were financed. Are the expected non-discounted annual savings sufficient in each year to cover the proposed contract payments? Does your analysis confirm the ESCO's estimate of annual operational savings of $\$ 120 \mathrm{~K}$ ?

\section{Scenario}

The building manager has already performed LCCAs on the individual ECMs and found them to be costeffective. She has decided to bundle the ECMs into one project, which she will compare with the base case of doing nothing. 


\section{General project information}

- ECMs in Training Facility, Jefferson, TN

- current-dollar analysis

- end-of-year discounting

- discount rate: $6.1 \%$ nominal

- inflation rate: $\mathbf{2 . 7 \%}$

- DOE energy price escalation rates

- all costs, except debt service payments, increase at rate of inflation 


\section{Key Dates}

- Base date:

June 2001

- Implementation period:

1 year

- Service date:

June 2002

- Contract period:

20 years

- Study period:

25 years 


\section{Base Case: Status Quo}

Initial cost:

Energy consumption:

Energy price:

AR OM\&R costs:

Expected system life: 25 years
\$0

4,584,396 kWh/yr

$\$ 0.04324 / \mathrm{kWh}$, commercial

$\$ 18,300$ 


\section{Alternative: ESPC}

Initial cost paid by agency:

Total capital costs financed:

Annual contract costs:

Debt service:

Performance period expenses:

Annual energy costs:

pre-impl. period:

post-impl. period:
$\$ 29,283$

$\$ 1,133,217$

$\$ 109,856$, fixed

$\$ 7,047$, increasing at $\mathbf{2 . 7 \%}$

Electricity: 4,584,396 kWh/yr at $\$ 0.04324 / \mathbf{k W h}$, commercial Natural Gas: 109,780 therms at $\$ 0.46 /$ therm, comm. 


\section{Alternative: ESPC (cont.)}

AR OM\&R costs

pre-impl. period:

contract period:

post-contract period:

Expected system life:

residual value:
$\$ 18,300$

included in contract payments

$\$ 4,871$

25 years

$4 \%$ 


\section{ESPC Project Timing}

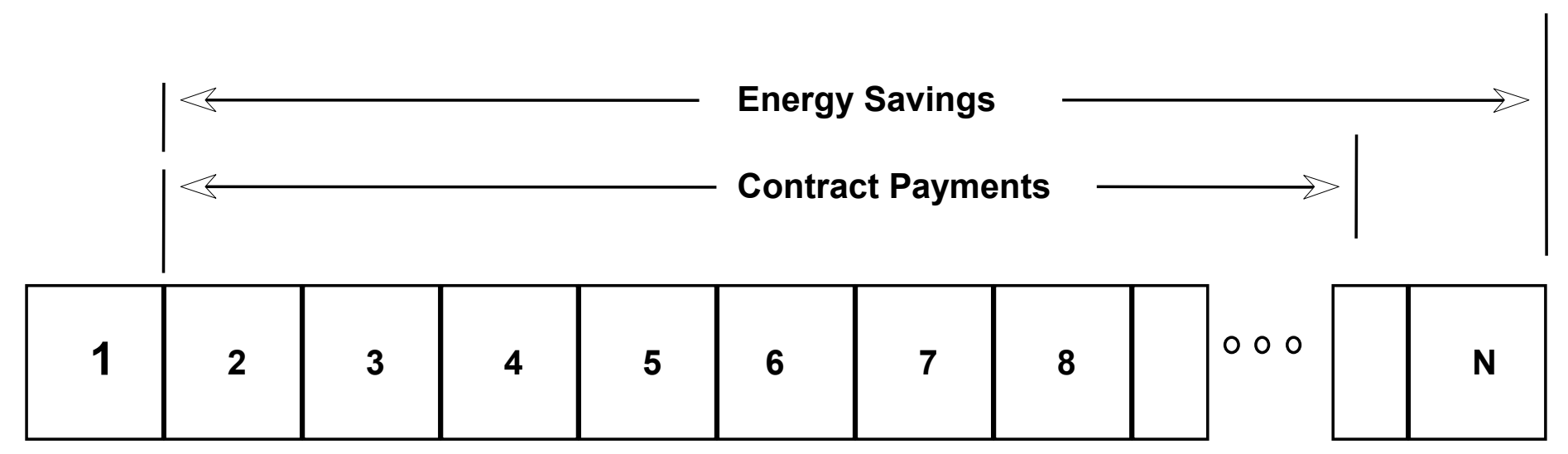

Implementation

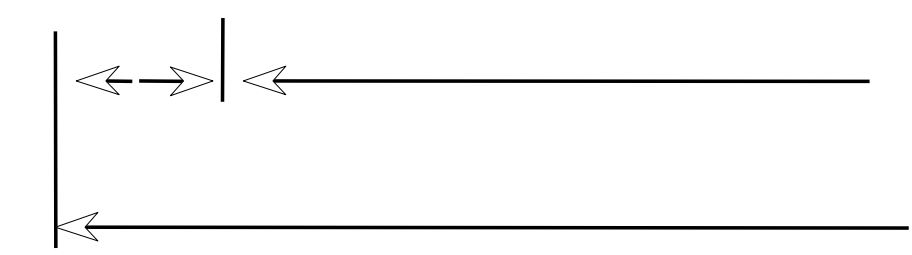

Base

Occupancy or Full

System Operation

Study

Period

End of

Study

Period 


\section{ESPC: Debt Service}

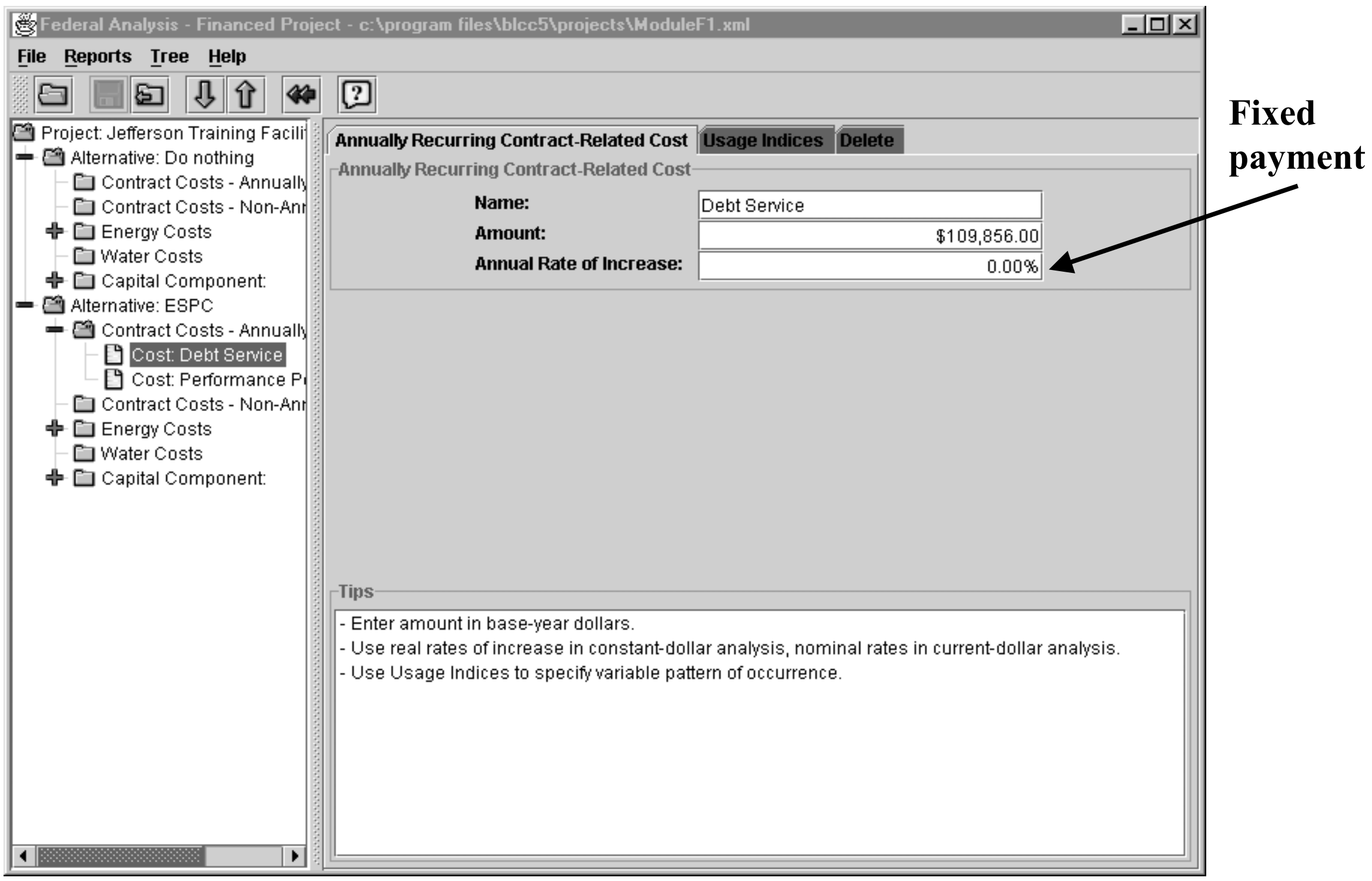




\section{ESPC: Performance Period Expenses}

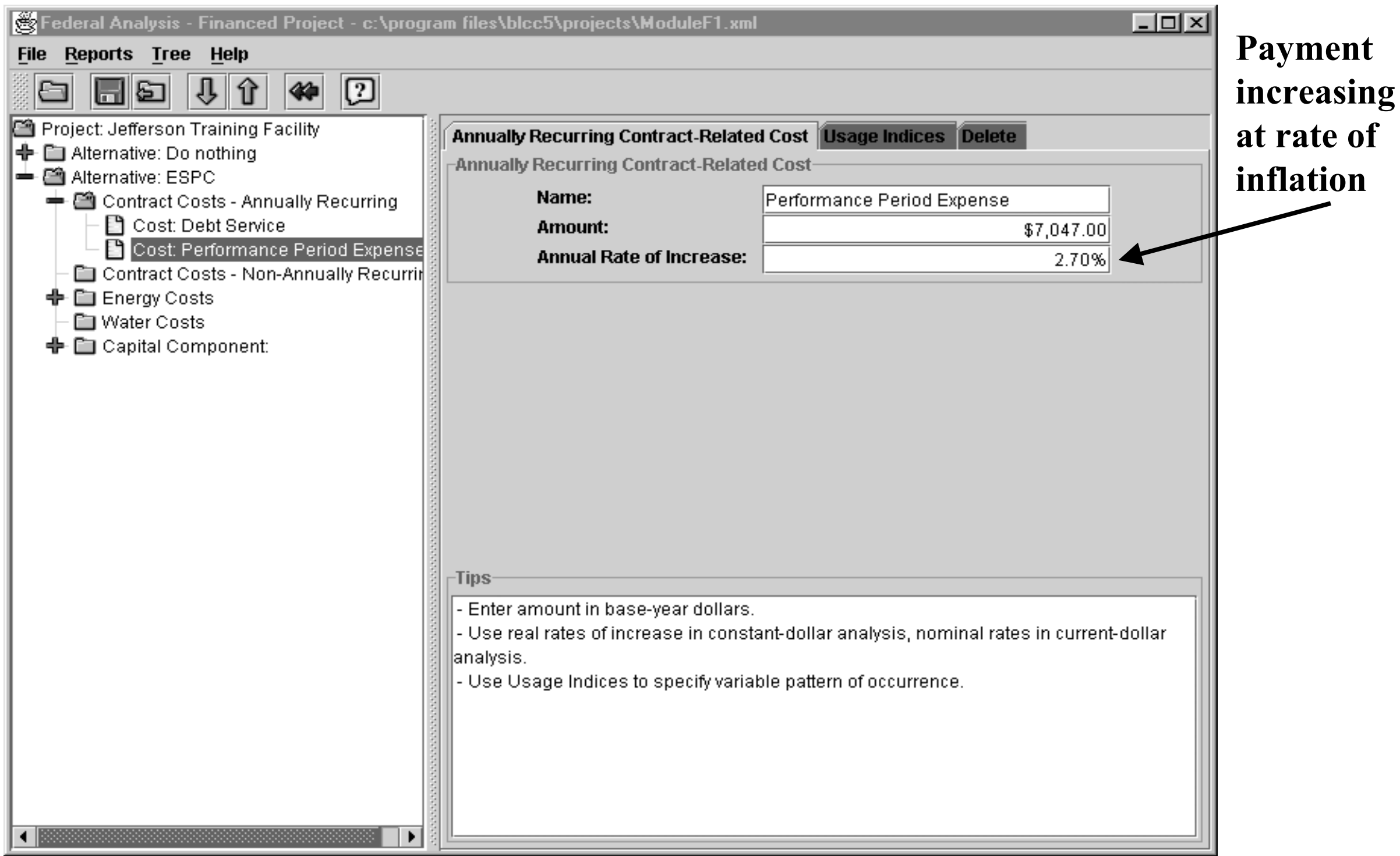




\section{ESPC: Electricity Usage}

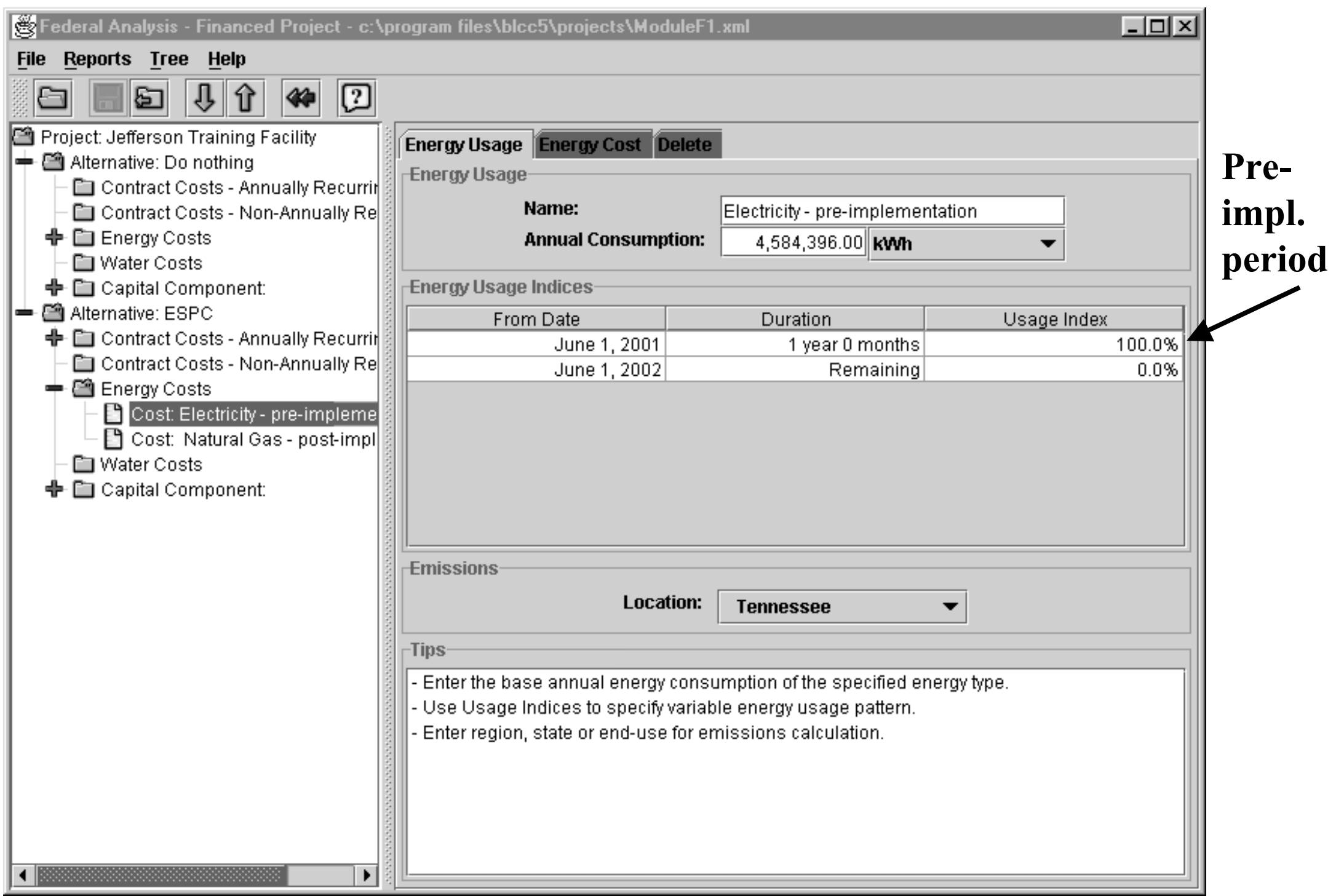




\section{ESPC: Natural Gas Usage}

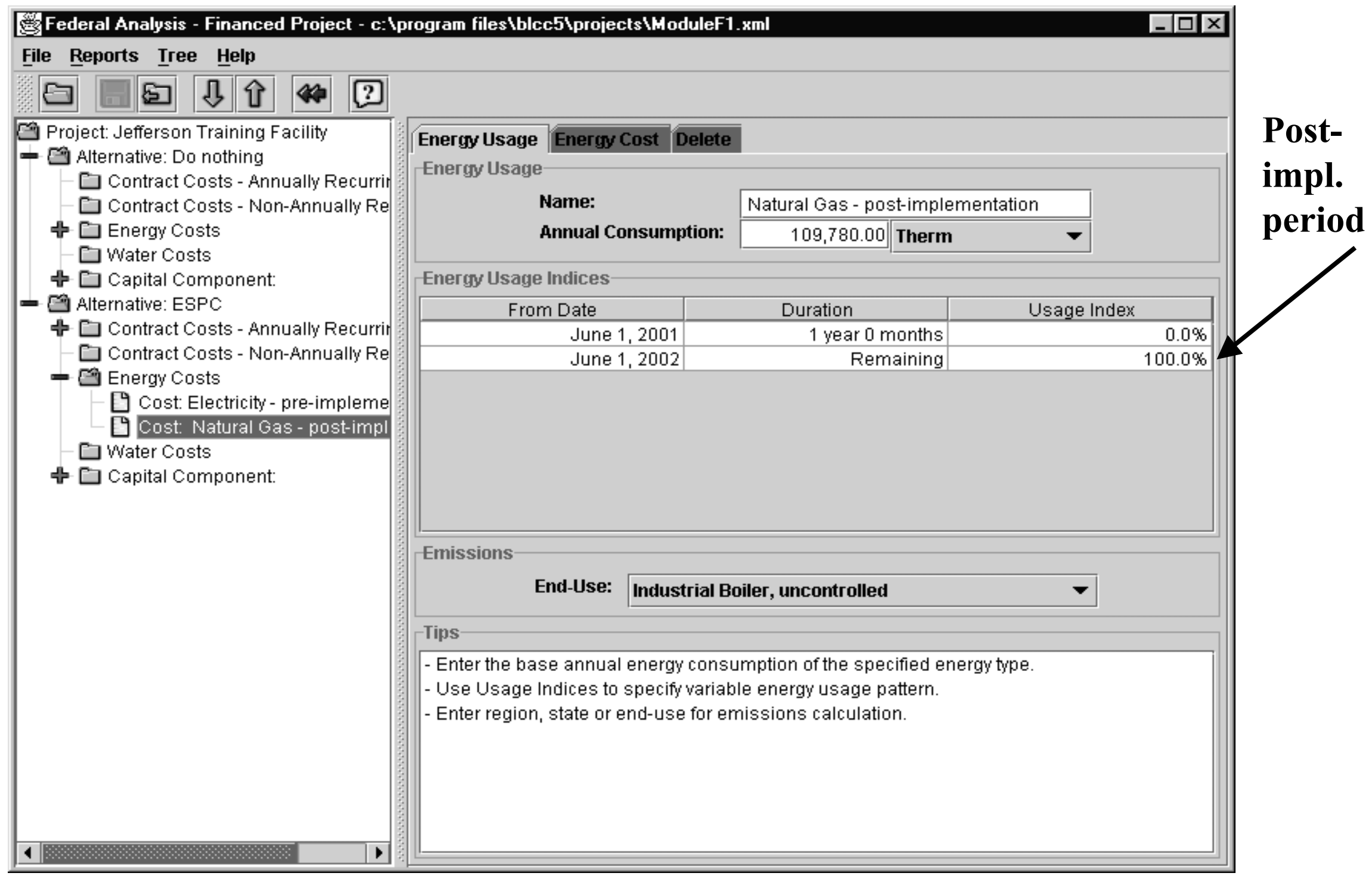




\section{ESPC: Initial Investment Costs}

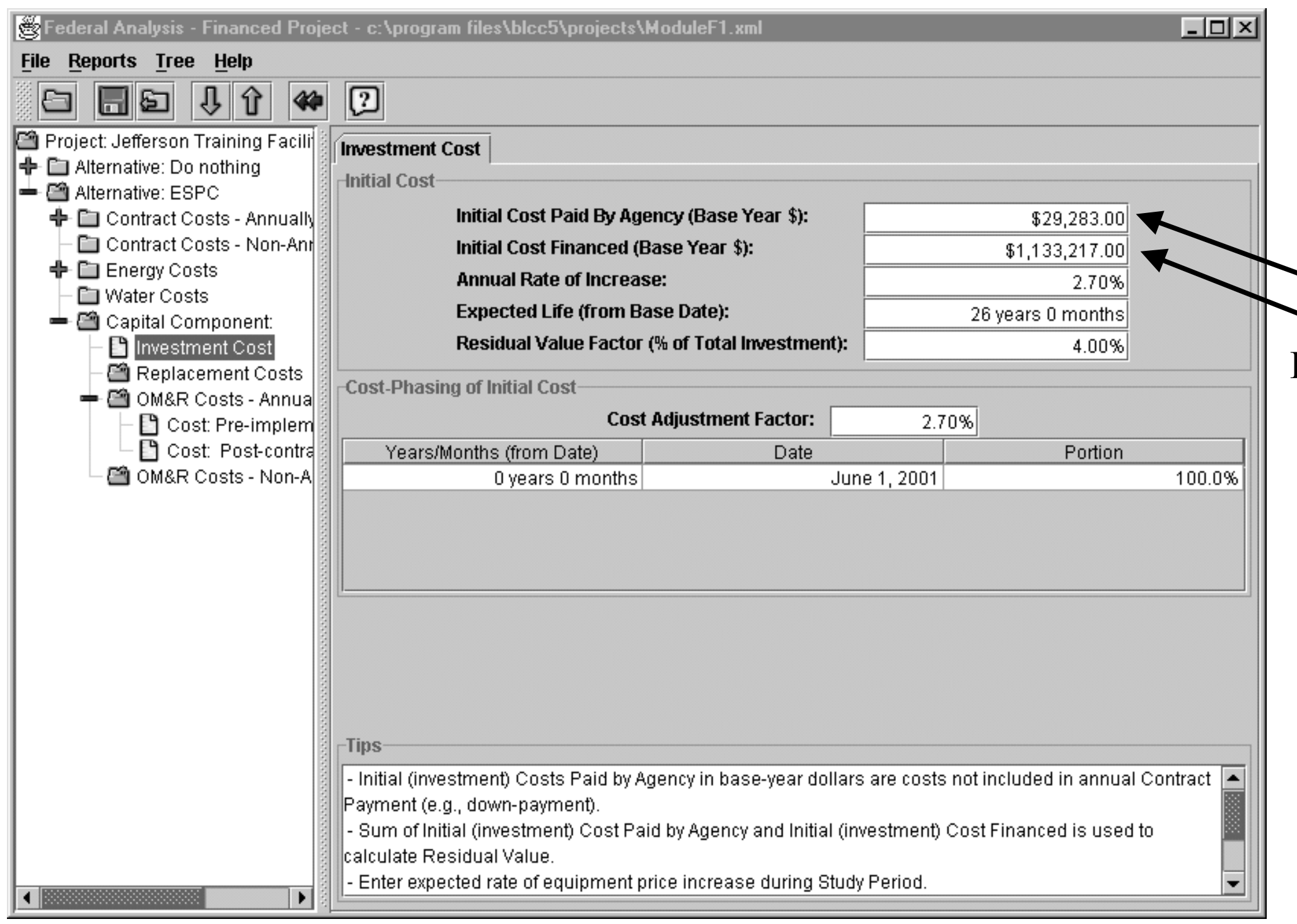




\section{ESPC: OM\&R Costs}

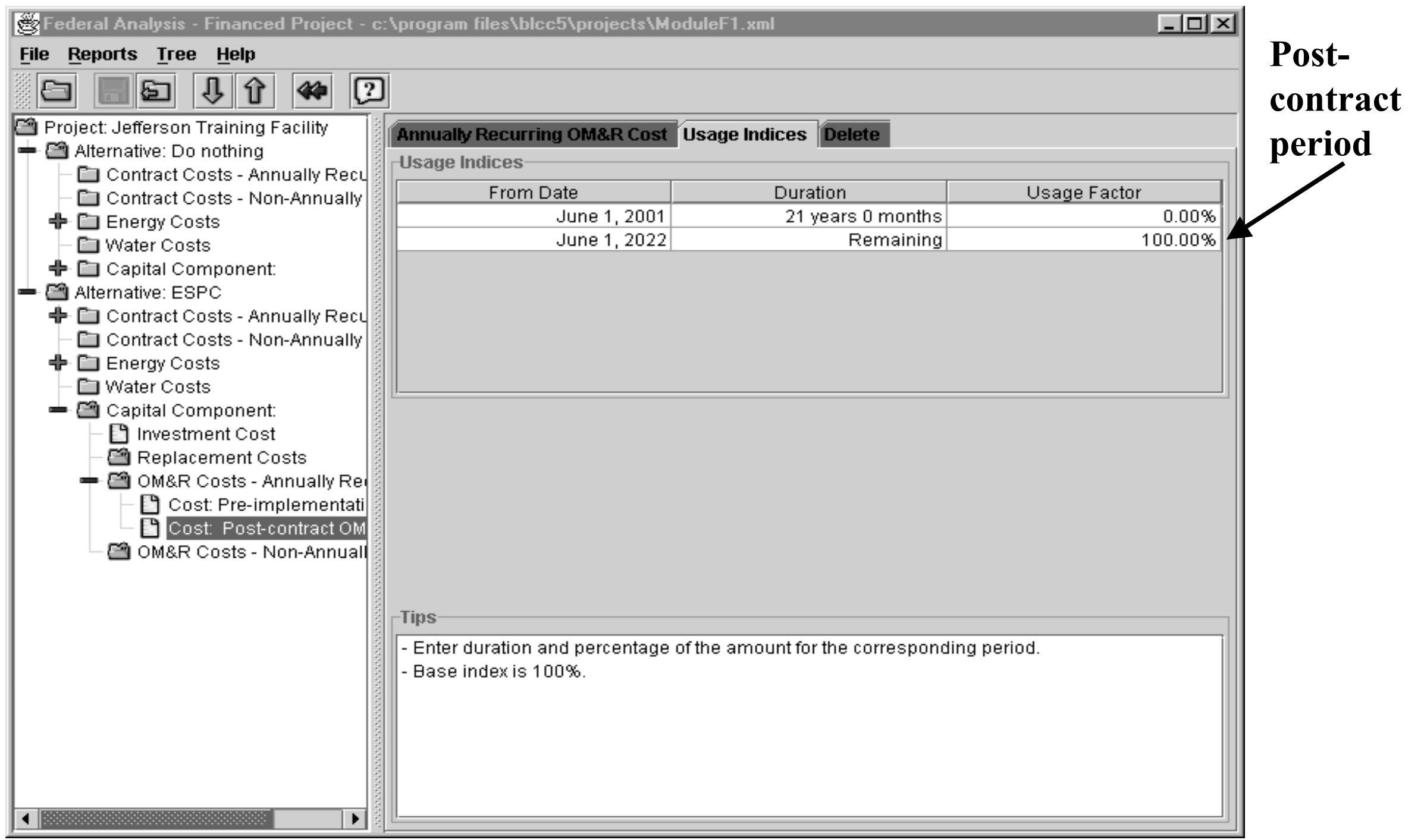




\section{Comparative Analysis Report}

菬 Comparative Analysis Report

File

Comparison of Present-Value costs

PV Life-Cycle Cost

Base Case Alternative Savings from Alternative

Initial Investment costs Paid By Agency:

Capital Requirements as of Base Date

$\$ 0 \quad \$ 29,283$

$-\xi 29,283$

Future Costs:

Recurring and Non-Recurring Contract Costs

Energy Consumption Costs

$\begin{array}{rrr}\$ 0 & \$ 1,278,134 & -\$ 1,278,134 \\ \$ 3,011,152 & \$ 926,995 & \$ 2,084,157 \\ \$ 0 & \$ 0 & \$ 0 \\ \$ 0 & \$ 0 & \$ 0 \\ \$ 0 & \$ 0 & \$ 0 \\ \$ 308,297 & \$ 26,809 & \$ 281,488 \\ \$ 0 & \$ 0 & \$ 0 \\ \$ 0 & -\$ 20,653 & ------------ \\ ---------- & ----------- & \$ 1,108,165 \\ \$ 3,319,449 & \$ 2,211,285 & ------------ \\ ---------- & ------------ & \$ 1,078,882\end{array}$

Total PY Life-CYcle cost

Net Savings from Alternative Compared with Base Case

$P V$ of Operational Savings $\$ 2,365,645$

- PV of Differential Costs $\$ 1,286,763$

Lowest LCC

Het Savings

$\$ 1,078,882$ 


\section{Comparative Analysis Report}






\section{Annualized PV Savings}

Use Uniform Capital Recovery Factor (UCR) to annualize Net Savings.

Annual NS $=$ Total Net Savings $x$ UCR

$=\$ 1,078,882 \times 0.0790$

$=\$ \mathbf{8 5 , 2 3 2}$

$($ UCR $=1 / U P V$, calculated using BLCC4 DISCOUNT Program) 


\section{Summary LCC Report}

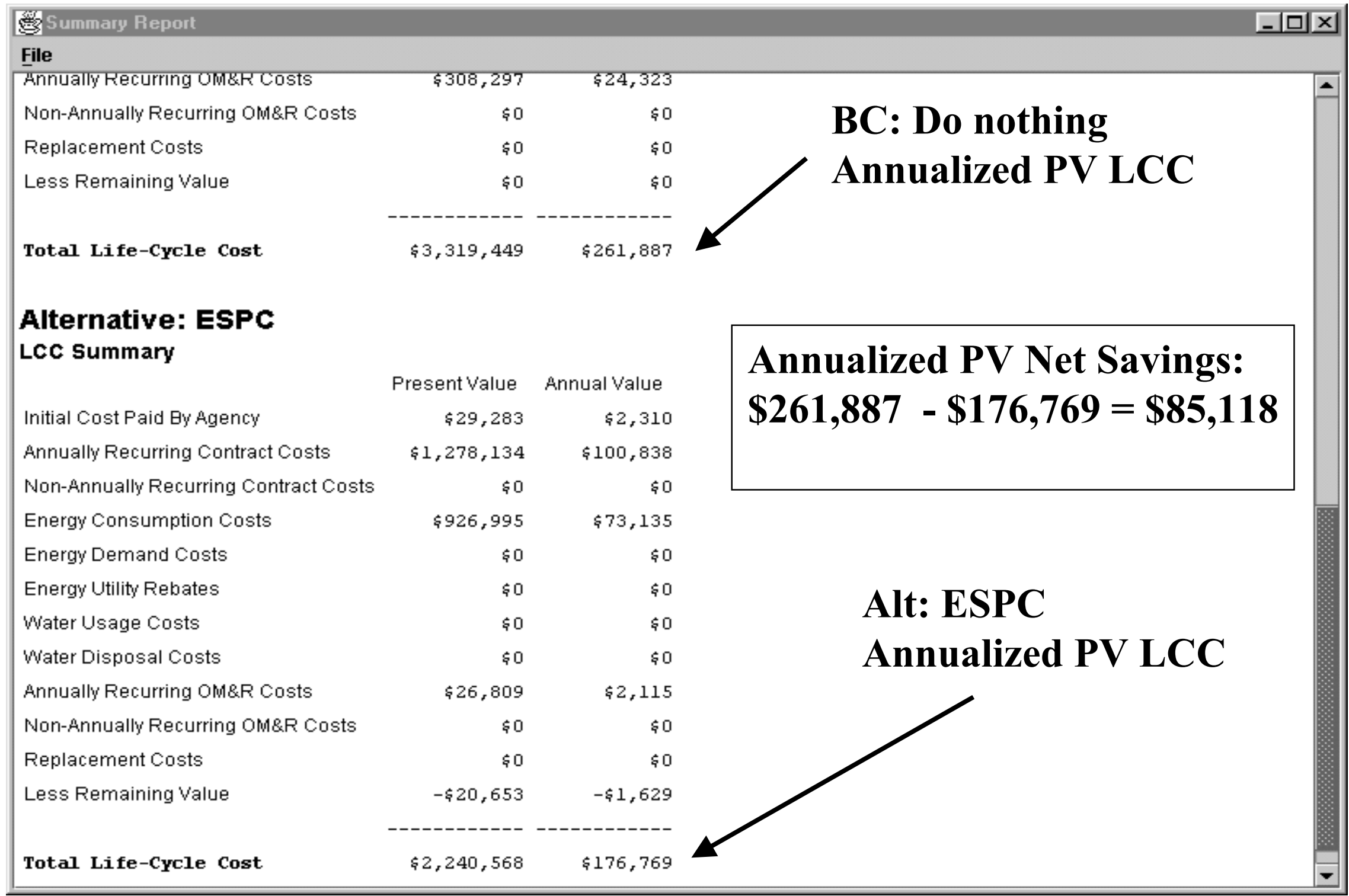




\section{Summary of Analysis Results}

- ESPC project is cost-effective.

- LCC lower than for status quo (Lowest LCC Report)

- positive NS for alternative (Comparative Analysis Report)

- annual non-discounted operational savings $>$ than contract payments (Comparative Analysis Report)

- operational savings proposed by ESCO confirmed

- Other considerations:

- emissions reduction achieved with ESPC project (Comparative Analysis Report) 


\section{Class Exercise F2}

\section{Financing Solar Water Heating System for A U.S. Coast Guard Base}

\section{PROBLEM STATEMENT}

The U.S. Coast Guard (CG) in Honolulu is seeking to evaluate the feasibility of utility financing to replace an existing electric resistance water heating system with a solar water heating system for 280 residences. To maintain the existing system, CG is planning to replace heater tanks at the rate of 28 tanks per year (assuming a 10-year useful life), with the first set of tank replacements being completed one year from the base date. As an alternative, they could replace the existing systems with an energy-efficient solar system that would be installed and financed through a contract with the local utility company and would be ready for operation in one year. CG would make a down payment of 15 percent of the total initial capital investment of $\$ 1,000,000$ at the base date and finance the remaining 85 percent over a contract term of 10 years, beginning one year from the base date. GG performs a life-cycle cost analysis to determine if the utility proposal is cost-effective relative to the base case of keeping the existing system.

\section{General Information}

\section{Location:}

Base date:

Service date:

Study period:

Government discount rate:

Discounting convention:

Rate of general inflation:

Electricity price:
Honolulu, HI

June 2001

June 2002 for both the base case and the alternative

20 years from base date

6.1 percent (including inflation)

Amounts discounted from end of each year to base date

2.7 percent (use current-dollar analysis)

$\$ 0.05 / \mathrm{kWh}$, industrial rate 


\section{Class Exercise F2 (cont.)}

\section{Base Case: Maintain and Repair Existing System}

Annual electricity cost:

Initial capital investment:

Capital replacement costs:

Years 6, 11, and 16:

Annually recurring $O M \& R$ costs:
$\$ 148,750(=2,975,000 \mathrm{kWh}$ at $\$ 0.05)$

None

$\$ 23,760$ for anode replacements

$\$ 32,220$ for tank replacements, at the rate of 28 tanks per year, assuming a 10-year tank life

\section{Alternative 1: Solar Water Heating System Financed through Utility Contract \\ Contract-related data:}

Contract term:

Loan payments:

Administrative costs:

Oversight costs:

Annual electricity cost:

Initial capital investment:
10 years, beginning one year from base date

$\$ 123,833$ per year during contract term, fixed

$\$ 1,000$ per year during contract term, increasing at the rate of inflation

$\$ 1,800$ at contract date

$\$ 27,100(=542,000 \mathrm{kWh}$ at $\$ 0.05)$

$\$ 1,000,000$

$15 \%(=\$ 150,000)$ down payment at base date

$85 \%$ ( $=\$ 850,000)$ financed through UC 


\section{Class Exercise F2 (cont.)}

Capital Replacement costs:

Year 11:

Year 11:

Year 16:

Annually recurring $O M \& R$ costs:
$\$ 30,000$ for replacing anodes and controls

$\$ 230,400$ for replacing tanks

$\$ 18,580$ for replacing valves, residual value $73 \%$

$\$ 7,600$ for routine maintenance, included in loan

payment during contract term 


\section{Solution to Class Exercise F2 \\ NIST BLCC 5.0-01: Input Data Listing \\ Consistent with Federal Life Cycle Cost Methodology and Procedures, 10 CFR, Part 436, Subpart A}

\section{General Information}

File Name:

Run Date:

Analysis Type:

Project Name:

Project Location:

Analyst:

Comment:

Base Date:

Study Period:

Discount Rate:

Discounting

Convention:
C: Program Files $\backslash B L C C 5 \backslash$ projects $\backslash$ Class Exercise F2.xml

Thu Sep 20 13:43:55 EDT 2001

Federal Analysis, Financed Project

Class Exercise F2

Hawaii

CDE

Evaluate feasibility of replacing electric resistance water heating system with solar system financed through utility energy services contract

June 1, 2001

20 years 0 months (June 1, 2001 through May 31, 2021)

$6.1 \%$

End-of-Year

Discount and Escalation Rates are NOMINAL (inclusive of general inflation)

\section{Alternative: Existing system}

Comment: Maintaining the system requires tank replacements at a rate of 28 tanks per year

\section{Energy: Electricity}

$\begin{array}{lr}\text { Annual Consumption: } & 2,975,000.0 \mathrm{kWh} \\ \text { Price per Unit: } & \$ 0.05000 \\ \text { Demand Charge: } & \$ 0 \\ \text { Utility Rebate: } & \$ 0 \\ \text { Location: } & \text { Hawaii } \\ \text { Rate Schedule: } & \text { Industrial } \\ \text { State: } & \text { Hawaii }\end{array}$

\section{Usage Indices}

From Date Duration Usage Index

June 1, 20011 year 0 months $\quad 0 \%$

June 1, 2002 Remaining 100\%

Escalation Rates

From Date Duration Escalation

April 1, 20011 year 0 months $\quad-1.36 \%$

April 1, 20021 year 0 months $\quad-1.16 \%$

April 1, 20031 year 0 months $\quad 1.16 \%$

April 1, 20041 year 0 months $\quad-2.15 \%$

April 1, 20051 year 0 months $\quad-1.74 \%$

April 1, 20061 year 0 months $\quad-3.57 \%$

April 1, 20071 year 0 months $\quad-1.14 \%$ 
April 1, 20081 year 0 months

April 1, 20091 year 0 months

April 1, 20101 year 0 months

April 1, 20111 year 0 months

April 1, 20121 year 0 months

April 1, 20131 year 0 months

April 1, 20141 year 0 months

April 1, 20151 year 0 months

April 1, 20161 year 0 months

April 1, 20171 year 0 months

April 1, 20181 year 0 months

April 1, 20191 year 0 months

April 1, 20201 year 0 months

April 1, 20211 year 0 months

April 1, 20221 year 0 months

April 1, 20231 year 0 months

April 1, 20241 year 0 months

April 1, 20251 year 0 months

April 1, 20261 year 0 months

April 1, 20271 year 0 months

April 1, 20281 year 0 months

April 1, 20291 year 0 months

April 1, 20301 year 0 months

April 1, 2031 Remaining

$$
\begin{array}{r}
1.37 \% \\
1.06 \% \\
1.53 \% \\
1.81 \% \\
2.8 \% \\
3.8 \% \\
3 \% \\
2.8 \% \\
3.88 \% \\
2.60 \% \\
2.41 \% \\
3.58 \% \\
3.09 \% \\
2.89 \% \\
2.89 \% \\
2.89 \% \\
2.89 \% \\
2.89 \% \\
2.89 \% \\
2.99 \% \\
2.89 \% \\
2.89 \% \\
2.89 \% \\
2.91 \% \\
\hline
\end{array}
$$

\section{Component:}

\section{Initial Investment}

Initial Cost Paid By Agency (base-year \$): $\quad \$ 0$

Initial Cost Financed (base-year \$): $\quad \$ 0$

Annual Rate of Increase: $\quad 2.7 \%$

Expected Asset Life: $\quad 20$ years 0 months

Residual Value Factor:

$0 \%$

\section{Cost-Phasing}

Cost Adjustment Factor: $2.7 \%$

Years/Months (from Date) Date Portion

0 years 0 months June 1, $2001 \quad 100 \%$

Replacement: Year 6 Anode Replacement

Years/Months: $\quad 6$ years 0 months

Amount: $\quad \$ 23,760$

Annual Rate Of Increase: $\quad 2.7 \%$

Expected Asset Life: $\quad 5$ years 0 months

Residual Value Factor: $\quad 0 \%$

\section{Replacement: Year 11 Anode Replacement}

Years/Months:

11 years 0 months 
Amount: $\quad \$ 23,760$

Annual Rate Of Increase: $\quad 2.7 \%$

Expected Asset Life: $\quad 5$ years 0 months

Residual Value Factor: $\quad 0 \%$

\section{Replacement: Year 16 Anode Replacement}

Years/Months: $\quad 16$ years 0 months

Amount: $\quad \$ 23,760$

Annual Rate Of Increase: $\quad 2.7 \%$

Expected Asset Life: $\quad 5$ years 0 months

Residual Value Factor: $\quad 20 \%$

\section{Recurring OM\&R: Tank replacement}

Amount: $\quad \$ 32,220$

Annual Rate of Increase: $\quad 2.7 \%$

Usage Indices

From Date Duration Factor

June 1, 20011 year 0 months $\quad 0 \%$

June 1, 2002 Remaining 100\%

\section{Alternative: Solar Water Heating System}

Comment: $85 \%$ of the cost of the solar water heating system will be financed through a utility contract

\section{Recurring Contract: Annual Loan Payment}

$\begin{array}{lr}\text { Amount: } & \$ 123,833 \\ \text { Annual Rate of Increase: } \quad 0 \%\end{array}$

Usage Indices

From Date Duration Factor

June 1, 20011 year 0 months $\quad 0 \%$

June 1, 200210 years 0 months $100 \%$

June 1, 2012 Remaining $\quad 0 \%$

Recurring Contract: Administrative Costs

Amount: $\quad \$ 1,000$

Annual Rate of Increase: $\quad 2.7 \%$

Usage Indices

From Date Duration Factor

June 1, 20011 year 0 months $\quad 0 \%$

June 1, 200210 years 0 months $100 \%$

June 1, 2012 Remaining $\quad 0 \%$

\section{Non-Recurring Contract: Oversight Cost}

Years/Months: $\quad 1$ year 0 months

Amount: $\quad \$ 1,800$

Annual Rate of Increase: $\quad 2.7 \%$ 


\section{Energy: Electricity}

Annual Consumption: $542,000.0 \mathrm{kWh}$

Price per Unit: $\quad \$ 0.05000$

Demand Charge: $\quad \$ 0$

Utility Rebate: \$0

Location: Hawaii

Rate Schedule: Industrial

State: Hawaii

\section{Usage Indices}

From Date Duration Usage Index

June 1, 20011 year 0 months $\quad 0 \%$

June 1, 2002 Remaining 100\%

\section{Escalation Rates}

\begin{tabular}{|c|c|}
\hline From Date & Escalation \\
\hline April 1, 20011 year 0 months & $-1.36 \%$ \\
\hline April 1, 20021 year 0 months & $-1.16 \%$ \\
\hline April 1, 20031 year 0 months & $1.16 \%$ \\
\hline April 1, 20041 year 0 months & $-2.15 \%$ \\
\hline April 1, 20051 year 0 months & $-1.74 \%$ \\
\hline April 1, 20061 year 0 months & $-3.57 \%$ \\
\hline April 1, 20071 year 0 months & $-1.14 \%$ \\
\hline April 1, 20081 year 0 months & $1.37 \%$ \\
\hline April 1, 20091 year 0 months & $1.06 \%$ \\
\hline April 1, 20101 year 0 months & $1.53 \%$ \\
\hline April 1, 20111 year 0 months & $1.81 \%$ \\
\hline April 1, 20121 year 0 months & $2.8 \%$ \\
\hline April 1, 20131 year 0 months & $3.8 \%$ \\
\hline April 1, 20141 year 0 months & $3 \%$ \\
\hline April 1, 20151 year 0 months & $2.8 \%$ \\
\hline April 1, 20161 year 0 months & $3.88 \%$ \\
\hline April 1, 20171 year 0 months & $2.60 \%$ \\
\hline April 1, 20181 year 0 months & $2.41 \%$ \\
\hline April 1, 20191 year 0 months & $3.58 \%$ \\
\hline April 1, 20201 year 0 months & $3.09 \%$ \\
\hline April 1, 20211 year 0 months & $2.89 \%$ \\
\hline April 1, 20221 year 0 months & $2.89 \%$ \\
\hline April 1, 20231 year 0 months & $2.89 \%$ \\
\hline April 1, 20241 year 0 months & $2.89 \%$ \\
\hline April 1, 20251 year 0 months & $2.89 \%$ \\
\hline April 1, 20261 year 0 months & $2.89 \%$ \\
\hline April 1, 20271 year 0 months & $2.99 \%$ \\
\hline April 1, 20281 year 0 months & $2.89 \%$ \\
\hline April 1, 20291 year 0 months & $2.89 \%$ \\
\hline April 1, 20301 year 0 months & $2.89 \%$ \\
\hline April 1, 2031 & 2.91 \\
\hline
\end{tabular}




\section{Component:}

\section{Initial Investment}

Initial Cost Paid By Agency (base-year \$): $\quad \$ 150,000$

Initial Cost Financed (base-year \$): $\quad \$ 850,000$

Annual Rate of Increase: $\quad 2.7 \%$

Expected Asset Life: $\quad 20$ years 0 months

Residual Value Factor: $\quad 0 \%$

\section{Cost-Phasing}

Cost Adjustment Factor: 2.7\%

Years/Months (from Date) Date Portion

0 years 0 months June 1, $2001 \quad 100 \%$

\section{Replacement: Anodes/Controls}

Years/Months: $\quad 11$ years 0 months

Amount: $\quad \$ 30,000$

Annual Rate Of Increase: $\quad 2.7 \%$

Expected Asset Life: 10 years 0 months

Residual Value Factor: $\quad 0 \%$

\section{Replacement: Tanks}

Years/Months: $\quad 11$ years 0 months

Amount: $\quad \$ 230,400$

Annual Rate Of Increase: $\quad 2.7 \%$

Expected Asset Life: 10 years 0 months

Residual Value Factor: $\quad 0 \%$

\section{Replacement: Valves}

Years/Months: $\quad 16$ years 0 months

Amount: $\quad \$ 18,580$

Annual Rate Of Increase: $\quad 2.7 \%$

Expected Asset Life: 15 years 0 months

Residual Value Factor: $\quad 73 \%$

\section{Recurring OM\&R: Routine OM\&R}

Amount: $\quad \$ 7,600$

Annual Rate of Increase: $\quad 2.7 \%$

Usage Indices

From Date Duration Factor

June 1, 200111 years 0 months $\quad 0 \%$

June 1, 2012 Remaining 100\% 


\section{NIST BLCC 5.0-01: Detailed LCC Analysis}

Consistent with Federal Life Cycle Cost Methodology and Procedures, 10 CFR, Part 436, Subpart A

\section{General Information}

File Name:

C: Program Files $\backslash B L C C 5 \backslash$ projects $\backslash$ Class Exercise F2.xml

Run Date:

Thu Sep 20 13:46:39 EDT 2001

Analysis Type:

Federal Analysis, Financed Project

Project Name:

Class Exercise F2

Project Location:

Hawaii

Analyst:

Comment:

Evaluate feasibility of replacing electric resistance water heating system with solar system financed through utility energy services contract

Base Date:

June 1, 2001

Study Period:

20 years 0 months (June 1, 2001 through May 31, 2021)

Discount Rate:

$6.1 \%$

Discounting

Convention:

End-of-Year

Discount and Escalation Rates are NOMINAL (inclusive of general inflation)

\section{Alternative: Existing system}

\section{Initial Cost Data (not Discounted)}

\section{Initial Capital Costs Paid By Agency}

(adjusted for price escalation)

Initial Capital Costs for All Components: $\$ 0$

Component:

Cost-Phasing

Date

June 1, 2001

Portion Yearly Cost

$100 \% \$ 0$

Total (for Component)

Initial Capital Costs Financed

(base-year dollars)

Initial Capital Costs for All Components: $\$ 0$

Component:

Initial Cost Financed $\$ 0$

Energy Costs: Electricity

(base-year dollars)

Average Average Average Average

Annual Usage Price/Unit Annual Cost Annual Demand Annual Rebate

$\begin{array}{lllll}2,826,331.5 \mathrm{kWh} & \$ 0.05000 & \$ 141,317 & \$ 0 & \$ 0\end{array}$

\section{Life-Cycle Cost Analysis}


Initial Capital Costs Paid By Agency

Contract-Related Costs

Annually Recurring Contract Costs

Non-Annually Recurring Contract Costs

Subtotal (for Contract):

\section{Energy Costs}

Energy Consumption Costs

Energy Demand Charges

Energy Utility Rebates

Subtotal (for Energy):

Water Usage Costs

Water Disposal Costs

Operating, Maintenance \& Repair Costs

Component:

Annually Recurring Costs

Non-Annually Recurring Costs

Subtotal (for OM\&R):

Replacements to Capital Components

Component:

Subtotal (for Replacements):

Residual Value of Original Capital Components

Component:

Subtotal (for Residual Value):

Residual Value of Capital Replacements

Component:

Subtotal (for Residual Value):

Total Life-Cycle Cost
Present Value Annual Value

$\$ 0$

$\$ 0$

$\begin{array}{rr}\$ 1,560,685 & \$ 137,063 \\ \$ 0 & \$ 0 \\ \$ 0 & \$ 0 \\ -1,560,685 & \$ 137,063 \\ & \\ \$ 0 & \$ 0 \\ \$ 0 & \$ 0\end{array}$

$\begin{array}{rr}\$ 435,177 & \$ 38,218 \\ \$ 0 & \$ 0 \\ ------- & ------- \\ \$ 435,177 & \$ 38,218\end{array}$

$\$ 50,312 \quad \$ 4,419$

$\$ 50,312 \quad \$ 4,419$
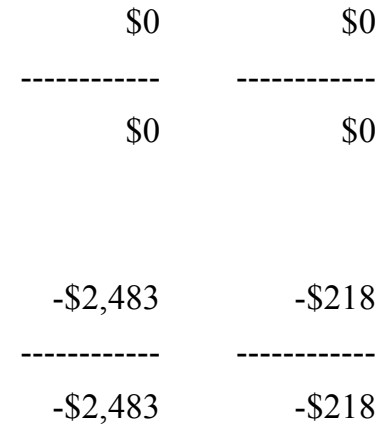

$\$ 2,043,691 \quad \$ 179,482$ 


\section{Emissions Summary}

Energy Name Annual Life-Cycle

Electricity:

$\begin{array}{rrr}\text { CO2 } & 2,206,103.08 \mathrm{~kg} & 44,116,021.53 \mathrm{~kg} \\ \text { SO2 } & 3,883.12 \mathrm{~kg} & 77,651.78 \mathrm{~kg} \\ \text { NOx } & 4,182.29 \mathrm{~kg} & 83,634.39 \mathrm{~kg}\end{array}$

Total:

CO2 2,206,103.08 kg 44,116,021.53 kg

SO2 $\quad 3,883.12 \mathrm{~kg} \quad 77,651.78 \mathrm{~kg}$

NOx $\quad 4,182.29 \mathrm{~kg} \quad 83,634.39 \mathrm{~kg}$

\section{Alternative: Solar Water Heating System Initial Cost Data (not Discounted)}

\section{Initial Capital Costs Paid By Agency}

(adjusted for price escalation)

Initial Capital Costs for All Components: $\$ 150,000$

Component:

Cost-Phasing

Date

Portion Yearly Cost

June 1, 2001

$100 \% \$ 150,000$

Total (for Component)

$\$ 150,000$

\section{Initial Capital Costs Financed}

(base-year dollars)

Initial Capital Costs for All Components: $\$ 850,000$

\section{Component:}

Initial Cost Financed $\$ 850,000$

Energy Costs: Electricity (base-year dollars)

$$
\text { Average Average Average Average }
$$

Annual Usage Price/Unit Annual Cost Annual Demand Annual Rebate

$\begin{array}{lllll}514,914.8 \mathrm{kWh} & \$ 0.05000 & \$ 25,746 & \$ 0 & \$ 0\end{array}$

\section{Life-Cycle Cost Analysis}

Initial Capital Costs Paid By Agency

Contract-Related Costs

Annually Recurring Contract Costs

Non-Annually Recurring Contract Costs
Present Value Annual Value

$$
\$ 150,000 \quad \$ 13,173
$$

$\begin{array}{rr}\$ 863,785 & \$ 75,860 \\ \$ 1,743 & \$ 153\end{array}$


Subtotal (for Contract):

\section{Energy Costs}

Energy Consumption Costs

Energy Demand Charges

Energy Utility Rebates

Subtotal (for Energy):

Water Usage Costs

Water Disposal Costs

Operating, Maintenance \& Repair Costs

Component:

Annually Recurring Costs

Non-Annually Recurring Costs

Subtotal (for OM\&R):

Replacements to Capital Components

Component:

Subtotal (for Replacements):

Residual Value of Original Capital Components

Component:

Subtotal (for Residual Value):

Residual Value of Capital Replacements

Component:

Subtotal (for Residual Value):

Total Life-Cycle Cost
$\$ 865,527 \quad \$ 76,013$

\begin{tabular}{rr}
$\$ 284,333$ & $\$ 24,971$ \\
$\$ 0$ & $\$ 0$ \\
$\$ 0$ & $\$ 0$ \\
\hdashline 284,333 & $\$ 24,971$ \\
& \\
$\$ 0$ & $\$ 0$ \\
$\$ 0$ & $\$ 0$
\end{tabular}

\begin{tabular}{rr}
$\$ 40,834$ & $\$ 3,586$ \\
$\$ 0$ & $\$ 0$ \\
- \hdashline 40,834 & $\$ 3,586$
\end{tabular}

$\begin{array}{rr}\$ 193,243 & \$ 16,971 \\ ---------- & -------- \\ \$ 193,243 & \$ 16,971\end{array}$

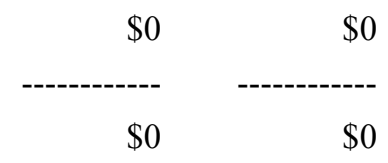

$\begin{array}{rr}-\$ 7,086 & -\$ 622 \\ -\$ 7,086 & -\$ 622\end{array}$

$\$ 1,526,852 \quad \$ 134,092$ 


\section{Emissions Summary}

$\begin{array}{crr}\begin{array}{c}\text { Energy Name } \\ \text { Electricity: }\end{array} & \text { Annual } & \text { Life-Cycle } \\ \text { CO2 } & 401,918.61 \mathrm{~kg} & 8,037,271.82 \mathrm{~kg} \\ \text { SO2 } & 707.45 \mathrm{~kg} & 14,146.98 \mathrm{~kg} \\ \text { NOx } & 761.95 \mathrm{~kg} & 15,236.92 \mathrm{~kg}\end{array}$

Total:

CO2 $401,918.61 \mathrm{~kg} 8,037,271.82 \mathrm{~kg}$

SO2 $\quad 707.45 \mathrm{~kg} \quad 14,146.98 \mathrm{~kg}$

NOx $\quad 761.95 \mathrm{~kg} \quad 15,236.92 \mathrm{~kg}$ 


\section{NIST BLCC 5.0-01: Comparative Analysis}

Consistent with Federal Life Cycle Cost Methodology and Procedures, 10 CFR, Part 436, Subpart A

Base Case: Existing system

Alternative: Solar Water Heating System

\section{General Information}

File Name:

Run Date:

Project Name:

Project Location:

Analysis Type:

Analyst:

Comment

Base Date of Study:

Service Date:

Study Period:

Discount Rate:

Discounting

Convention:
C:\Program Files $\backslash$ BLCC5 $\backslash$ projects $\backslash$ Class Exercise F2.xml

Thu Sep 20 13:52:25 EDT 2001

Class Exercise F2

Hawaii

Federal Analysis, Financed Project

CDE

Evaluate feasibility of replacing electric resistance water heating system with solar system financed through utility energy services contract

June 1, 2001

June 1, 2001

20 years 0 months(June 1, 2001 through May 31, 2021)

$6.1 \%$

End-of-Year

\section{Comparison of Present-Value Costs}

\section{PV Life-Cycle Cost}

Base Case Alternative Savings from Alternative

Initial Investment Costs Paid By Agency:

Capital Requirements as of Base Date

$\$ 0 \$ 150,000$

$-\$ 150,000$

Future Costs:

\begin{tabular}{|c|c|c|c|}
\hline Recurring and Non-Recurring Contract Costs & $\$ 0$ & $\$ 865,527$ & $-\$ 865,527$ \\
\hline Energy Consumption Costs & $\$ 1,560,685$ & $\$ 284,333$ & $\$ 1,276,352$ \\
\hline Energy Demand Charges & $\$ 0$ & $\$ 0$ & $\$ 0$ \\
\hline Energy Utility Rebates & $\$ 0$ & $\$ 0$ & $\$ 0$ \\
\hline Water Costs & $\$ 0$ & $\$ 0$ & $\$ 0$ \\
\hline Recurring and Non-Recurring OM\&R Costs & $\$ 435,177$ & $\$ 40,834$ & $\$ 394,343$ \\
\hline Capital Replacements & $\$ 50,312$ & $\$ 193,243$ & $-\$ 142,931$ \\
\hline Residual Value at End of Study Period & $-\$ 2,483$ & $-\$ 7,086$ & $\$ 4,603$ \\
\hline Subtotal (for Future Cost Items) & $\$ 2,043,691$ & $\$ 1,376,852$ & $\$ 666,840$ \\
\hline otal PV Life- & $\$ 2,043,691$ & $\$ 1,526,852$ & $\$ 516,840$ \\
\hline
\end{tabular}

Net Savings from Alternative Compared with Base Case

PV of Operational Savings \$1,670,694 
- PV of Differential Costs $\$ 1,153,855$

Net Savings

$\$ 516,840$

NOTE: Meaningful SIR, AIRR and Payback can not be computed for Financed Projects.

\section{Comparison of Contract Payments and Savings from Alternative}

(undiscounted)

Savings in Savings in Savings in Savings in

Year Beginning Contract Costs Energy Costs Total Operational Costs Total Costs

Jun 2001

Jun 2002

Jun 2003

Jun 2004

Jun 2005

Jun 2006

Jun 2007

Jun 2008

Jun 2009

Jun 2010

Jun 2011

Jun 2012

Jun 2013

Jun 2014

Jun 2015

Jun 2016

Jun 2017

Jun 2018

Jun 2019

Jun 2020
$\$ 0$

$-\$ 126,736$

-\$124,916

$-\$ 124,945$

$-\$ 124,975$

-\$125,006

-\$125,038

$-\$ 125,070$

-\$125,104

-\$125,138

$-\$ 125,173$

$\$ 0$

$\$ 0$

$\$ 0$

$\$ 0$

$\$ 0$

$\$ 0$

$\$ 0$

$\$ 0$

$\$ 0$
$\$ 0$

$\$ 119,101$

$\$ 119,827$

$\$ 117,330$

$\$ 114,938$

$\$ 111,293$

$\$ 110,474$

$\$ 111,931$

$\$ 113,206$

$\$ 114,985$

$\$ 117,256$

$\$ 120,728$

$\$ 125,149$

$\$ 128,856$

$\$ 132,697$

$\$ 137,561$

$\$ 141,095$

$\$ 144,760$

$\$ 149,834$

$\$ 154,396$
$\$ 0 \quad-\$ 150,000$

$\$ 153,081 \quad \$ 26,345$

$\$ 154,726 \quad \$ 29,810$

$\$ 153,171 \quad \$ 28,225$

$\$ 151,746 \quad \$ 26,771$

$\$ 149,094 \quad \$ 24,087$

$\$ 149,298 \quad \$ 52,137$

$\$ 151,802 \quad \$ 26,732$

$\$ 154,153 \quad \$ 29,049$

$\$ 157,037 \quad \$ 31,898$

$\$ 160,445 \quad \$ 35,272$

$\$ 154,620 \quad-\$ 162,607$

$\$ 159,956 \quad \$ 159,956$

$\$ 164,601 \quad \$ 164,601$

$\$ 169,410 \quad \$ 169,410$

$\$ 175,265 \quad \$ 175,265$

$\$ 179,816 \quad \$ 187,750$

$\$ 184,526 \quad \$ 184,526$

$\$ 190,675 \quad \$ 190,675$

$\$ 196,336 \quad \$ 211,347$

\section{Energy Savings Summary}

\section{Energy Savings Summary (in stated units)}

Energy -----Average Annual Consumption----- Life-Cycle

Type Base Case Alternative Savings Savings

Electricity 2,826,331.5 kWh 514,914.8 kWh 2,311,416.6 kWh 46,222,004.1 kWh

\section{Energy Savings Summary (in MBtu)}

$\begin{array}{lcccc}\text { Energy } & ---- \text { Average } & \text { Annual } & \text { Consumption---- } & \text { Life-Cycle } \\ \text { Type } & \text { Base Case } & \text { Alternative } & \text { Savings } & \text { Savings } \\ \text { Electricity } & 9,643.8 \mathrm{MBtu} & 1,757.0 \mathrm{MBtu} & 7,886.9 \mathrm{MBtu} & \text { 157,716.0 MBtu }\end{array}$




\section{Emissions Reduction Summary}

$\begin{array}{lcccc}\text { Energy } & -----A v e r a g e & \text { Annual } & \text { Emissions---- } & \text { Life-Cycle } \\ \text { Type } & \text { Base Case } & \text { Alternative } & \text { Reduction } & \text { Reduction }\end{array}$

Electricity

CO2 2,206,103.08 kg 401,918.61 kg 1,804,184.46 kg 36,078,749.71 kg

$\begin{array}{llll}\text { SO2 } & 3,883.12 \mathrm{~kg} & 707.45 \mathrm{~kg} & 3,175.67 \mathrm{~kg} \quad 63,504.80 \mathrm{~kg}\end{array}$

NOx $\quad 4,182.29 \mathrm{~kg} \quad 761.95 \mathrm{~kg} \quad 3,420.34 \mathrm{~kg} \quad 68,397.47 \mathrm{~kg}$

Total:

CO2 2,206,103.08 kg 401,918.61 kg 1,804,184.46 kg 36,078,749.71 kg

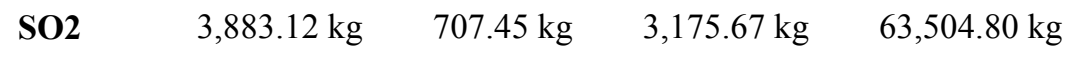

NOx $\quad 4,182.29 \mathrm{~kg} \quad 761.95 \mathrm{~kg} \quad 3,420.34 \mathrm{~kg} \quad 68,397.47 \mathrm{~kg}$ 



\section{Module G \\ Class Exercises}




\section{Class Exercise G1}

Water Conservation

A military barracks at Fort Meade, MD, housing 200 enlisted men, uses 800,000 gallons of water per year at a cost of $\$ 4.00 / 1000$ gallons of use plus $\$ 5.00 / 1000$ gallons sewer charge. This barracks is scheduled to be replaced with a new barracks in seven years. A water conservation project is proposed that will reduce usage and disposal by $25 \%$ at an initial cost of $\$ 5,000$ and which will not have maintenance costs over the seven years of remaining building life. All of the project components have a life expectancy of seven years or more. Water usage and disposal prices are expected to increase by an average of $5 \%$ year over general inflation for the remaining life of the building. During the last two years of the barracks' life, the occupancy level (and thus water consumption) is expected to be half of the current level.

The base date and service date are specified as June 2001. Use the mid-year discounting convention.

Using BLCC5, compute the life-cycle water-related costs before and after the retrofit project. Compute Net Savings and Savings-to-Investment Ratio. Would you recommend this project be undertaken? 


\section{Class Exercise G2}

Chiller Replacement

As energy manager of a federal research facility, you are tasked with replacing the existing 1000-ton chiller, which has an expected remaining life of 10 years but must be replaced to eliminate CFC usage. You have submitted technical specifications and operating conditions to all large chiller manufacturers and asked for bid responses which are to include the following cost and energy-related data: first cost, annual energy costs based on current electricity costs, and the operating schedule that you submit. The manufacturers must calculate annual energy usage and peak energy usage for their system using a standardized energy-estimating method. You inform the manufacturers that you will select the bid with the lowest 25-year life-cycle cost, using current FEMP LCC criteria (3.3\% discount rate and DOE escalation rates (South (Texas), industrial rates) and the BLCC computer program to perform the LCC calculations. Since you expect that maintenance costs after the end of the 10-year service contract will be similar for all systems, O\&M costs can be ignored after year 10. Current electricity costs are $\$ .048 / \mathrm{kWh}$ for electricity usage (same during winter and summer) and $\$ 104 / \mathrm{kW}$-y demand charge for peak $\mathrm{kW}$ demand. (Multiply the maximum annual $\mathrm{kW}$ demand by $\$ 104$ to get the annual demand charge.) Water costs and other operating costs are assumed to be similar for all systems for the purpose of this competition. The base date and service date for all LCC analyses are specified as June 2001. Use the end-of-year discounting convention. 


\section{Class Exercise G2 (cont.)}

Three manufacturers responded to this submission, with the following proposals:

\begin{tabular}{|l|r|r|r|}
\hline & \multicolumn{1}{|c|}{ Best Freeze } & \multicolumn{1}{|c|}{ Icy Nights } & \multicolumn{1}{c|}{ Snow Drift } \\
\hline First Cost & $\$ 360,000$ & $\$ 256,000$ & $\$ 310,000$ \\
\hline Annual kWh & $3,125,407$ & $2,984,564$ & $2,728,486$ \\
\hline Maximum kW & 600 & 560 & 530 \\
\hline $\begin{array}{l}\text { Service Contract } \\
\text { Year: }\end{array}$ & & & \\
\hline $\mathbf{1}$ & $\$ 4,000$ & $\$ 10,000$ & $\$ 0$ \\
\hline $\mathbf{2}$ & $\$ 4,000$ & $\$ 10,000$ & $\$ 0$ \\
\hline $\mathbf{3}$ & $\$ 6,000$ & $\$ 10,000$ & $\$ 0$ \\
\hline $\mathbf{4}$ & $\$ 6,000$ & $\$ 10,000$ & $\$ 0$ \\
\hline $\mathbf{5}$ & $\$ 8,000$ & $\$ 10,000$ & $\$ 15,000$ \\
\hline $\mathbf{6}$ & $\$ 8,000$ & $\$ 10,000$ & $\$ 15,000$ \\
\hline $\mathbf{7}$ & $\$ 10,000$ & $\$ 10,000$ & $\$ 15,000$ \\
\hline $\mathbf{8}$ & $\$ 10,000$ & $\$ 10,000$ & $\$ 15,000$ \\
\hline $\mathbf{9}$ & $\$ 20,000$ & $\$ 10,000$ & $\$ 15,000$ \\
\hline $\mathbf{1 0}$ & $\$ 20,000$ & $\$ 10,000$ & $\$ 15,000$ \\
\hline & & & \\
\hline LCC & $\mathbf{\$ 3 , 7 6 1 , 9 5 0}$ & $\mathbf{\$ 3 , 4 9 4 , 2 2 9}$ & $\mathbf{\$ 3 , 2 9 3 , 6 2 4}$ \\
\hline
\end{tabular}

Your job is to check the LCC computations submitted by each of the manufacturers before announcing who has won the bid competitions. 


\section{Class Exercise G3}

\section{Alternative Financing of Energy Conservation Project}

A federal agency in Arizona is considering replacing an existing lighting system in an office building with a new lighting/daylighting system financed through a utility contract. The existing lighting system is expected to be operational for another 15 years. Use BLCC5 to perform an LCC analysis.

\section{Project Information}

Location:

Base Date:

Study Period:

Contract Term:

Discount Rate:

Annual Rate of Inflation:

Discounting Convention:
Arizona

June 2001

15 years

10 years

$6.1 \%$

$2.7 \%$

end-of-year 


\section{Class Exercise G3 (cont.)}

\section{Base Case}

Initial Investment Cost:

Energy Type:

Annual Usage:

Price:
0

Electricity

$1,082,633 \mathrm{kWh}$

$\$ 0.04600 / \mathrm{kWh}$, commercial

Annual Demand Charge: \$30,105

Annual OM\&R costs:

$\$ 5,600$

\section{Alternative}

Amount Borrowed:

$\$ 390,480$

Expected Life:

20 years

Residual Value Factor:

$25 \%$

Annual Contract Payment:

$\$ 62,000$, fixed

Energy Type:

Electricity

Annual Usage:

$206,911 \mathrm{kWh}$

Price:

$\$ 0.04600 / \mathrm{kWh}$, commercial

Annual Demand Charge: \$3,311

Annual OM\&R:

$\$ 0$ during contract term

$\$ 3,000$ in years 11 through 15 


\section{Class Exercise G4}

\section{Lease Versus Buy Decision (BLCC4 Exercise)}

A federal government agency is considering building a new office building with 60,000 square feet of office space on land that it already owns at an initial cost of $\$ 5,000,000$. A private investment firm offers to build the same building on private land across the street from the proposed site and lease this facility to the government for 20 years at an annual lease rate of $\$ 500,000$, with an annual escalation clause that is tied directly to the rate of general inflation. Major building maintenance, which will cost the government $\$ 200,000$ per year at current prices, is included in the lease amount. All utility costs and other building operating-related costs will be the same for both buildings. The building has an expected life of 50 years and a residual value at the end of the study period equal to $50 \%$ of its initial cost, in constant dollar terms. Which alternative is more advantageous to the government?

Use the Federal Analysis--Projects Subject to OMB A-94 Module in BLCC4. June 2001 should be used for the base date and service date. Use the end-of-year discounting convention. The projected annual rate of general inflation is $2.7 \%$. Can this analysis be performed in constant dollars? 


\title{
Solution to Class Exercise G1 \\ NIST BLCC 5.0-01: Input Data Listing \\ Consistent with Federal Life Cycle Cost Methodology and Procedures, 10 CFR, Part 436, Subpart A
}

\section{General Information}

File Name:

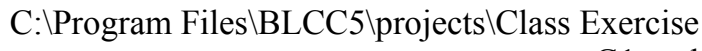

G1.xml

Run Date:

Thu Sep 20 14:08:19 EDT 2001

Analysis Type:

Project Name:

Class Exercise G1

Project Location:

Maryland

Analyst:

ASR

Comment:

Military Barracks at Fort Meade, MD

Base Date:

June 1, 2001

Service Date:

June 1, 2001

Study Period:

7 years 0 months (June 1, 2001 through May 31, 2008)

Discount Rate:

$3.3 \%$

Discounting Convention:

Mid-Year

Discount and Escalation Rates are REAL (exclusive of general inflation)

\section{Alternative: Existing}

Water: Water

\author{
Annual Usage Annual Disposal \\ Units/Year Price/Unit Units/Year Price/Unit
}

(a) Summer Rates 800.0 ThousGal $\$ 4.00000800 .0$ ThousGal $\$ 5.00000$

(a) Winter Rates $\quad 0.0$ ThousGal $\$ 0.00000 \quad 0.0$ ThousGal $\$ 0.00000$

Escalation Rates - Usage

From Date Duration Usage Cost Escalation

June 1, 2001 Remaining $\quad 5.00 \%$

Escalation Rates - Disposal

From Date Duration Disposal Cost Escalation

June 1, 2001 Remaining $\quad 5.00 \%$

Usage Indices - Usage

From Date Duration Index

June 1, 20015 years 0 months $100 \%$

June 1, 2006 Remaining 50\% 


\title{
Usage Indices - Disposal
}

From Date Duration Index

June 1, 20015 years 0 months 100\%

June 1, 2006 Remaining 50\%

\section{Component:}

\section{Initial Investment}

Initial Cost (base-year \$): $\quad \$ 0$

Annual Rate of Increase: $\quad 0 \%$

Expected Asset Life: $\quad 0$ years 0 months

Residual Value Factor: $\quad 0 \%$

\section{Cost-Phasing}

Cost Adjustment Factor: 0\%

Years/Months (from Date) Date Portion

0 years 0 months June 1, $2001 \quad 100 \%$

\section{Alternative: Water Project}

Water: Water

\author{
Annual Usage \\ Annual Disposal \\ Units/Year Price/Unit Units/Year Price/Unit
}

@Summer Rates 600.0 ThousGal $\$ 4.00000$ 600.0 ThousGal $\$ 5.00000$

@Winter Rates $\quad 0.0$ ThousGal $\$ 0.00000 \quad 0.0$ ThousGal $\$ 0.00000$

Escalation Rates - Usage

From Date Duration Usage Cost Escalation

June 1, 2001 Remaining $\quad 5.00 \%$

Escalation Rates - Disposal

From Date Duration Disposal Cost Escalation

June 1, 2001 Remaining

$5.00 \%$

Usage Indices - Usage

From Date Duration Index

June 1, 20015 years 0 months 100\%

June 1, $2006 \quad$ Remaining 50\%

Usage Indices - Disposal

From Date Duration Index

June 1, 20015 years 0 months 100\%

June 1, 2006 Remaining 50\%

\section{Component:}

\section{Initial Investment}

Initial Cost (base-year \$): $\quad \$ 5,000$ 
Annual Rate of Increase:

$0 \%$

Expected Asset Life: 7 years 0 months

Residual Value Factor: $\quad 0 \%$

\section{Cost-Phasing}

Cost Adjustment Factor: 0\%

Years/Months (from Date) Date Portion

0 years 0 months June 1, 2001 100\% 


\section{Base Case: Existing Alternative: Water Project \\ General Information}

$\begin{array}{lr}\text { File Name: } & \text { C: } \backslash \text { Program Files\BLCC5 } \backslash \text { projects } \backslash \text { Class Exercise G1.xml } \\ \text { Run Date: } & \text { Thu Sep 20 14:10:47 EDT 2001 } \\ \text { Project Name: } & \text { Class Exercise G1 } \\ \text { Project Location: } & \text { Maryland } \\ \text { Analysis Type: } & \text { Federal Analysis, Agency-Funded Project } \\ \text { Analyst: } & \text { ASR } \\ \text { Comment } & \text { Military Barracks at Fort Meade, MD } \\ \text { Base Date of Study: } & \text { June 1, 2001 } \\ \text { Service Date: } & \text { June 1, 2001 } \\ \text { Study Period: } & 7 \text { years } 0 \text { months(June 1, 2001 through May 31, 2008) } \\ \text { Discount Rate: } & 3.3 \% \\ \text { Discounting Convention: } & \text { Mid-Year }\end{array}$

\section{Comparison of Present-Value Costs}

\section{PV Life-Cycle Cost}

Base Case Alternative Savings from Alternative

Initial Investment Costs:

Capital Requirements as of Base Date

$\$ 0 \quad \$ 5,000$

$-\$ 5,000$

Future Costs:

Energy Consumption Costs

$\$ 0 \quad \$ 0 \quad \$ 0$

Energy Demand Charges

$\$ 0 \quad \$ 0$

$\$ 0$

Energy Utility Rebates

$\$ 0 \quad \$ 0$

$\$ 0$

Water Costs

$\$ 45,450$

$\$ 34,088$

$\$ 11,363$

Recurring and Non-Recurring OM\&R Costs

$\$ 0$

$\$ 0$

$\$ 0$

Capital Replacements

$\$ 0$

$\$ 0$

Residual Value at End of Study Period

$\$ 0$

$\$ 0$

$\$ 0$

Subtotal (for Future Cost Items)

$\begin{array}{rr}\$ 45,450 & \$ 34,088 \\ - & \end{array}$

$\$ 11,363$

Total PV Life-Cycle Cost

$\$ 45,450-\$ 39,088$

$\$ 6,363$

\section{Net Savings from Alternative Compared with Base Case}

\begin{tabular}{lr} 
PV of Non-Investment Savings & $\$ 11,363$ \\
- Increased Total Investment & $\$ 5,000$ \\
\hline & --------- \\
\hline Net Savings & $\$ 6,363$
\end{tabular} 


\section{Savings-to-Investment Ratio (SIR)}

$\operatorname{SIR}=2.27$

\section{Adjusted Internal Rate of Return}

AIRR $=16.16 \%$

\section{Payback Period}

Estimated Years to Payback (from beginning of Service Period)

Simple Payback occurs in year 3

Discounted Payback occurs in year 3 


\section{Solution to Class Exercise G2 \\ NIST BLCC 5.0-01: Input Data Listing \\ Consistent with Federal Life Cycle Cost Methodology and Procedures, 10 CFR, Part 436, Subpart A}

\section{General Information}

File Name:

C: $\backslash$ Program Files $\backslash$ BLCC5 $\backslash$ projects $\backslash$ Class Exercise

G2.xml

Run Date:

Thu Sep 20 14:23:51 EDT 2001

Analysis Type:

Project Name:

Class Exercise G2

Project Location:

Texas

Analyst:

ASR

Base Date:

June 1, 2001

Service Date:

June 1, 2001

Study Period:

25 years 0 months (June 1, 2001 through May 31, 2026)

Discount Rate:

$3.3 \%$

Discounting Convention:

End-of-Year

Discount and Escalation Rates are REAL (exclusive of general inflation)

\section{Alternative: Best Freeze}

\section{Energy: Electricity}

Annual Consumption: $3,125,407.0 \mathrm{kWh}$

Price per Unit:

$\$ 0.04800$

Demand Charge:

$\$ 62,400$

Utility Rebate:

Location:

Texas

Rate Schedule:

Industrial

State:

Texas

\section{Usage Indices}

From Date Duration Usage Index

June 1, 2001 Remaining 100\%

\section{Escalation Rates}

\begin{tabular}{|c|c|}
\hline From Date & Escalation \\
\hline April 1, 20011 year 0 months & $-1.99 \%$ \\
\hline April 1, 20021 year 0 months & $-1.22 \%$ \\
\hline April 1, 20031 year 0 months & $-0.25 \%$ \\
\hline April 1, 20041 year 0 months & $-1.32 \%$ \\
\hline April 1, 20051 year 0 months & $-1.09 \%$ \\
\hline April 1, 20061 year 0 months & $-1.52 \%$ \\
\hline pril 1, 20071 year 0 months & $-1.2 \%$ \\
\hline pril 1, 20081 year 0 months & $-0.87^{\circ}$ \\
\hline pril 1, 20091 year 0 mol & -0 . \\
\hline
\end{tabular}


April 1, 20101 year 0 months

April 1, 20111 year 0 months

April 1, 20121 year 0 months

April 1, 20131 year 0 months

April 1, 20141 year 0 months

April 1, 20151 year 0 months

April 1, 20161 year 0 months

April 1, 20171 year 0 months

April 1, 20181 year 0 months

April 1, 20191 year 0 months

April 1, 20201 year 0 months

April 1, 20211 year 0 months

April 1, 20221 year 0 months

April 1, 20231 year 0 months

April 1, 20241 year 0 months

April 1, 20251 year 0 months

April 1, 20261 year 0 months

April 1, 20271 year 0 months

April 1, 20281 year 0 months

April 1, 20291 year 0 months

April 1, 20301 year 0 months

April 1, 2031 Remaining
$-0.79 \%$

$-0.8 \%$

$-0.27 \%$

$0.36 \%$

$0.36 \%$

$0.62 \%$

$0.79 \%$

$0.79 \%$

$0.43 \%$

$0.61 \%$

$0.26 \%$

$0.26 \%$

$0.26 \%$

$0.17 \%$

$0.26 \%$

$0.25 \%$

$0.17 \%$

$0.25 \%$

$0.25 \%$

$0.25 \%$

$0.17 \%$

$0.22 \%$

\section{Component:}

\section{Initial Investment}

Initial Cost (base-year \$): $\quad \$ 360,000$

Annual Rate of Increase: $\quad \quad 0 \%$

Expected Asset Life: $\quad 25$ years 0 months

Residual Value Factor: $\quad 0 \%$

\section{Cost-Phasing}

Cost Adjustment Factor: 0\%

Years/Months (from Date) Date Portion

0 years 0 months June 1, $2001 \quad 100 \%$

Non-Recurring OM\&R: Year 1

Years/Months: $\quad 1$ year 0 months

Amount: $\quad \$ 4,000$

Annual Rate of Increase: $\quad 0 \%$

\section{Non-Recurring OM\&R: Year 2}

Years/Months: $\quad 2$ years 0 months

Amount: $\quad \$ 4,000$

Annual Rate of Increase: $\quad \quad 0 \%$

\section{Non-Recurring OM\&R: Year 3}

Years/Months: $\quad 3$ years 0 months 
Amount: $\quad \$ 6,000$

Annual Rate of Increase: $\quad 0 \%$

Non-Recurring OM\&R: Year 4

Years/Months: $\quad 4$ years 0 months

Amount: $\quad \$ 6,000$

Annual Rate of Increase: $\quad \quad 0 \%$

Non-Recurring OM\&R: Year 5

Years/Months: $\quad 5$ years 0 months

Amount: $\quad \$ 8,000$

Annual Rate of Increase: $\quad \quad 0 \%$

Non-Recurring OM\&R: Year 6

Years/Months: $\quad 6$ years 0 months

Amount: $\quad \$ 8,000$

Annual Rate of Increase: $\quad \quad 0 \%$

Non-Recurring OM\&R: Year 7

Years/Months: $\quad 7$ years 0 months

Amount: $\quad \$ 10,000$

Annual Rate of Increase: $\quad \quad 0 \%$

Non-Recurring OM\&R: Year 8

Years/Months: $\quad 8$ years 0 months

Amount: $\quad \$ 10,000$

Annual Rate of Increase: $\quad \quad 0 \%$

Non-Recurring OM\&R: Year 9

Years/Months: $\quad 9$ years 0 months

Amount: $\quad \$ 20,000$

Annual Rate of Increase: $\quad \quad 0 \%$

Non-Recurring OM\&R: Year 10

Years/Months: $\quad 10$ years 0 months

Amount: $\quad \$ 20,000$

Annual Rate of Increase: $\quad \quad 0 \%$

\section{Alternative: Icy Nights}

\section{Energy: Electricity}

Annual Consumption: $2,984,564.0 \mathrm{kWh}$

Price per Unit:

$\$ 0.04800$

Demand Charge:

$\$ 58,240$

Utility Rebate:

Location:

Texas

Rate Schedule:

Industrial

State:

Texas 


\section{Usage Indices}

From Date Duration Usage Index

June 1, 2001 Remaining 100\%

\section{Escalation Rates}

\begin{tabular}{|c|c|}
\hline From Date & Escalation \\
\hline April 1, 20011 year 0 months & $-1.99 \%$ \\
\hline April 1, 20021 year 0 months & $-1.22 \%$ \\
\hline April 1, 20031 year 0 months & $-0.25 \%$ \\
\hline April 1, 20041 year 0 months & $-1.32 \%$ \\
\hline April 1, 20051 year 0 months & $-1.09 \%$ \\
\hline April 1, 20061 year 0 months & $-1.52 \%$ \\
\hline April 1, 20071 year 0 months & $-1.2 \%$ \\
\hline April 1, 20081 year 0 months & $-0.87 \%$ \\
\hline April 1, 20091 year 0 months & $-0.35 \%$ \\
\hline April 1, 20101 year 0 months & $-0.79 \%$ \\
\hline April 1, 20111 year 0 months & $-0.8 \%$ \\
\hline April 1, 20121 year 0 months & $-0.27 \%$ \\
\hline April 1, 20131 year 0 months & $0.36 \%$ \\
\hline April 1, 20141 year 0 months & $0.36 \%$ \\
\hline April 1, 20151 year 0 months & $0.62 \%$ \\
\hline April 1, 20161 year 0 months & $0.79 \%$ \\
\hline April 1, 20171 year 0 months & $0.79 \%$ \\
\hline April 1, 20181 year 0 months & $0.43 \%$ \\
\hline April 1, 20191 year 0 months & $0.61 \%$ \\
\hline April 1, 20201 year 0 months & $0.26 \%$ \\
\hline April 1, 20211 year 0 months & $0.26 \%$ \\
\hline April 1, 20221 year 0 months & $0.26 \%$ \\
\hline April 1, 20231 year 0 months & $0.17 \%$ \\
\hline April 1, 20241 year 0 months & $0.26 \%$ \\
\hline April 1, 20251 year 0 months & $0.25 \%$ \\
\hline April 1, 20261 year 0 months & $0.17 \%$ \\
\hline April 1, 20271 year 0 months & $0.25 \%$ \\
\hline April 1, 20281 year 0 months & $0.25 \%$ \\
\hline April 1, 20291 year 0 months & $0.25 \%$ \\
\hline April 1, 20301 year 0 months & $0.17 \%$ \\
\hline April 1, $2031 \quad$ Remaining & $0.22 \%$ \\
\hline
\end{tabular}

\section{Component:}

\section{Initial Investment}

Initial Cost (base-year \$): $\quad \$ 256,000$

Annual Rate of Increase: $\quad 0 \%$

Expected Asset Life: $\quad 25$ years 0 months

Residual Value Factor: $\quad 0 \%$

\section{Cost-Phasing}

Cost Adjustment Factor: 0\% 
Years/Months (from Date) Date Portion

0 years 0 months June 1, $2001 \quad 100 \%$

Non-Recurring OM\&R: Year 1

Years/Months: 1 year 0 months

Amount: $\quad \$ 10,000$

Annual Rate of Increase: $\quad 0 \%$

Non-Recurring OM\&R: Year 2

Years/Months: 2 years 0 months

Amount: $\quad \$ 10,000$

Annual Rate of Increase: $\quad 0 \%$

Non-Recurring OM\&R: Year 3

Years/Months: 3 years 0 months

Amount: $\quad \$ 10,000$

Annual Rate of Increase: $\quad 0 \%$

Non-Recurring OM\&R: Year 4

Years/Months: $\quad 4$ years 0 months

Amount: $\quad \$ 10,000$

Annual Rate of Increase: $\quad 0 \%$

Non-Recurring OM\&R: Year 5

Years/Months: 5 years 0 months

Amount: $\quad \$ 10,000$

Annual Rate of Increase: $\quad 0 \%$

Non-Recurring OM\&R: Year 6

Years/Months: $\quad 6$ years 0 months

Amount: $\quad \$ 10,000$

Annual Rate of Increase: $\quad 0 \%$

Non-Recurring OM\&R: Year 7

Years/Months: $\quad 7$ years 0 months

Amount: $\quad \$ 10,000$

Annual Rate of Increase: $\quad 0 \%$

Non-Recurring OM\&R: Year 8

Years/Months: $\quad 8$ years 0 months

Amount: $\quad \$ 10,000$

Annual Rate of Increase: $\quad 0 \%$

Non-Recurring OM\&R: Year 9

Years/Months: $\quad 9$ years 0 months

Amount: $\quad \$ 10,000$

Annual Rate of Increase: $\quad 0 \%$ 
Non-Recurring OM\&R: Year 10

Years/Months: 10 years 0 months

Amount: $\quad \$ 10,000$

Annual Rate of Increase: $\quad 0 \%$

\section{Alternative: Snow Drift}

\section{Energy: Electricity}

$\begin{array}{lr}\text { Annual Consumption: } & 2,728,486.0 \mathrm{kWh} \\ \text { Price per Unit: } & \$ 0.04800 \\ \text { Demand Charge: } & \$ 55,120 \\ \text { Utility Rebate: } & \$ 0 \\ \text { Location: } & \text { Texas } \\ \text { Rate Schedule: } & \text { Industrial } \\ \text { State: } & \text { Texas }\end{array}$

\section{Usage Indices}

From Date Duration Usage Index

June 1, 2001 Remaining 100\%

\section{Escalation Rates}

From Date Duration Escalation April 1, 20011 year 0 months $\quad-1.99 \%$

April 1, 20021 year 0 months $\quad-1.22 \%$

April 1, 20031 year 0 months $\quad-0.25 \%$

April 1, 20041 year 0 months $\quad-1.32 \%$

April 1, 20051 year 0 months $\quad-1.09 \%$

April 1, 20061 year 0 months $\quad-1.52 \%$

April 1, 20071 year 0 months $\quad-1.2 \%$

April 1, 20081 year 0 months $\quad-0.87 \%$

April 1, 20091 year 0 months $\quad-0.35 \%$

April 1, 20101 year 0 months $\quad-0.79 \%$

April 1, 20111 year 0 months $\quad-0.8 \%$

April 1, 20121 year 0 months $\quad-0.27 \%$

April 1, 20131 year 0 months $\quad 0.36 \%$

April 1, 20141 year 0 months $\quad 0.36 \%$

April 1, 20151 year 0 months $\quad 0.62 \%$

April 1, 20161 year 0 months $\quad 0.79 \%$

April 1, 20171 year 0 months $\quad 0.79 \%$

April 1, 20181 year 0 months $\quad 0.43 \%$

April 1, 20191 year 0 months $\quad 0.61 \%$

April 1, 20201 year 0 months $\quad 0.26 \%$

April 1, 20211 year 0 months $\quad 0.26 \%$

April 1, 20221 year 0 months $\quad 0.26 \%$

April 1, 20231 year 0 months $\quad 0.17 \%$

April 1, 20241 year 0 months $\quad 0.26 \%$

April 1, 20251 year 0 months $\quad 0.25 \%$ 
April 1, 20261 year 0 months

April 1, 20271 year 0 months

$0.25 \%$

April 1, 20281 year 0 months

$0.25 \%$

April 1, 20291 year 0 months

$0.25 \%$

April 1, 20301 year 0 months

$0.17 \%$

April 1, $2031 \quad$ Remaining

$0.22 \%$

\section{Component:}

\section{Initial Investment}

Initial Cost (base-year \$): $\quad \$ 310,000$

Annual Rate of Increase: $\quad 0 \%$

Expected Asset Life: 25 years 0 months

Residual Value Factor: $\quad 0 \%$

\section{Cost-Phasing}

Cost Adjustment Factor: 0\%

Years/Months (from Date) Date Portion

0 years 0 months June 1, $2001 \quad 100 \%$

Non-Recurring OM\&R: Year 1

Years/Months: $\quad 1$ year 0 months

Amount: $\quad \$ 0$

Annual Rate of Increase: $\quad 0 \%$

Non-Recurring OM\&R: Year 2

Years/Months: $\quad 2$ years 0 months

Amount: $\quad \$ 0$

Annual Rate of Increase: $\quad \quad 0 \%$

Non-Recurring OM\&R: Year 3

Years/Months: $\quad 3$ years 0 months

Amount: $\quad \$ 0$

Annual Rate of Increase: $\quad \quad 0 \%$

Non-Recurring OM\&R: Year 4

Years/Months: $\quad 4$ years 0 months

Amount: $\$ 0$

Annual Rate of Increase: $\quad 0 \%$

Non-Recurring OM\&R: Year 5

Years/Months: $\quad 5$ years 0 months

Amount: $\quad \$ 15,000$

Annual Rate of Increase: $\quad \quad 0 \%$

Non-Recurring OM\&R: Year 6

Years/Months: $\quad 6$ years 0 months

Amount: $\quad \$ 15,000$

Annual Rate of Increase: $\quad 0 \%$ 
Non-Recurring OM\&R: Year 7

Years/Months: $\quad 7$ years 0 months

Amount:

$\$ 15,000$

Annual Rate of Increase:

$0 \%$

Non-Recurring OM\&R: Year 8

Years/Months: $\quad 8$ years 0 months

Amount: $\quad \$ 15,000$

Annual Rate of Increase: $\quad \quad 0 \%$

Non-Recurring OM\&R: Year 9

Years/Months: $\quad 9$ years 0 months

Amount: $\quad \$ 15,000$

Annual Rate of Increase: $\quad \quad 0 \%$

Non-Recurring OM\&R: Year 10

Years/Months: $\quad 10$ years 0 months

Amount: $\quad \$ 15,000$

Annual Rate of Increase: $\quad \quad 0 \%$ 


\section{NIST BLCC 5.0-01: Summary LCC \\ Consistent with Federal Life Cycle Cost Methodology and Procedures, 10 CFR, Part 436, Subpart A}

\section{General Information}

File Name:

Run Date:

Analysis Type:

Project Name:

Project Location:

Analyst:

Base Date:

Service Date:

Study Period:

Discount Rate:

Discounting Convention:
$\mathrm{C}: \backslash$ Program Files $\backslash$ BLCC $5 \backslash$ projects $\backslash$ Class Exercise

$\mathrm{G} 2 . \mathrm{xml}$

Thu Sep 20 14:28:42 EDT 2001

Federal Analysis, Agency-Funded Project

Class Exercise G2

Texas

ASR

June 1, 2001

June 1, 2001

25 years 0 months (June 1, 2001 through May 31, 2026)

$3.3 \%$

End-of-Year

Discount and Escalation Rates are REAL (exclusive of general inflation)

\section{Alternative: Best Freeze}

\section{LCC Summary}

Initial Cost

Energy Consumption Costs

Energy Demand Costs

Energy Utility Rebates

Water Usage Costs

Water Disposal Costs

Annually Recurring OM\&R Costs

Non-Annually Recurring OM\&R Costs

Replacement Costs

Less Remaining Value

Total Life-Cycle Cost
Present Value Annual Value

$\begin{array}{rr}\$ 360,000 & \$ 21,373 \\ \$ 2,348,369 & \$ 139,422 \\ \$ 976,794 & \$ 57,992 \\ \$ 0 & \$ 0 \\ \$ 0 & \$ 0 \\ \$ 0 & \$ 0 \\ \$ 0 & \$ 0 \\ \$ 76,787 & \$ 4,559 \\ \$ 0 & \$ 0 \\ \$ 0 & \$ 0 \\ --------- & ---------- \\ \$ 3,761,950 & \$ 223,345\end{array}$

\section{Alternative: Icy Nights}

\section{LCC Summary}

Initial Cost

Energy Consumption Costs

Energy Demand Costs

Energy Utility Rebates

Water Usage Costs

Water Disposal Costs
Present Value Annual Value

$\begin{array}{rr}\$ 256,000 & \$ 15,199 \\ \$ 2,242,542 & \$ 133,139 \\ \$ 911,675 & \$ 54,126 \\ \$ 0 & \$ 0 \\ \$ 0 & \$ 0 \\ \$ 0 & \$ 0\end{array}$


Annually Recurring OM\&R Costs

Non-Annually Recurring OM\&R Costs

Replacement Costs

Less Remaining Value

Total Life-Cycle Cost

\begin{tabular}{rr}
$\$ 0$ & $\$ 0$ \\
$\$ 84,012$ & $\$ 4,988$ \\
$\$ 0$ & $\$ 0$ \\
$\$ 0$ & $\$ 0$ \\
\hline $3,494,229$ & $\$ 207,451$
\end{tabular}

\section{Alternative: Snow Drift}

\section{LCC Summary}

Initial Cost

Energy Consumption Costs

Energy Demand Costs

Energy Utility Rebates

Water Usage Costs

Water Disposal Costs

Annually Recurring OM\&R Costs

Non-Annually Recurring OM\&R Costs

Replacement Costs

Less Remaining Value

Total Life-Cycle Cost
Present Value Annual Value

$\begin{array}{rr}\$ 310,000 & \$ 18,405 \\ \$ 2,050,130 & \$ 121,715 \\ \$ 862,835 & \$ 51,226 \\ \$ 0 & \$ 0 \\ \$ 0 & \$ 0 \\ \$ 0 & \$ 0 \\ \$ 0 & \$ 0 \\ \$ 70,659 & \$ 4,195 \\ \$ 0 & \$ 0 \\ \$ 0 & \$ 0 \\ ---------- & ----------- \\ \$ 3,293,624 & \$ 195,541\end{array}$




\section{Solution to Class Exercise G3 \\ NIST BLCC 5.0-01: Input Data Listing \\ Consistent with Federal Life Cycle Cost Methodology and Procedures, 10 CFR, Part 436, Subpart A}

\section{General Information}

File Name:

Run Date:

Analysis Type:

Project Name:

Project Location:

Analyst:

Comment:

Base Date:

Study Period:

Discount Rate:

Discounting Convention:
C: $\backslash$ Program Files $\backslash$ BLCC5 $\backslash$ projects $\backslash$ Class Exercise G3.xml

Thu Sep 20 14:31:20 EDT 2001

Federal Analysis, Financed Project

Class Exercise G3

Arizona

ASR

Replace existing lighting system with new system financed through a utility contract.

June 1,2001

15 years 0 months (June 1, 2001 through May 31, 2016)

$6.1 \%$

End-of-Year

Discount and Escalation Rates are NOMINAL (inclusive of general inflation)

\section{Alternative: Existing}

Comment: Base Case: Keep existing system for remaining 15 years of its useful life.

\section{Energy: Electricity}

$\begin{array}{lr}\text { Annual Consumption: } & 1,082,633.0 \mathrm{kWh} \\ \text { Price per Unit: } & \$ 0.04600 \\ \text { Demand Charge: } & \$ 30,105 \\ \text { Utility Rebate: } & \$ 0 \\ \text { Location: } & \text { Arizona } \\ \text { Rate Schedule: } & \text { Commercial } \\ \text { State: } & \text { Arizona }\end{array}$

\section{Usage Indices}

From Date Duration Usage Index

June 1, 2001 Remaining 100\%

\section{Escalation Rates}

\begin{tabular}{|c|c|}
\hline te & \\
\hline $1 \mathrm{ye}$ & $-0.6 \%$ \\
\hline 11,20021 year & \\
\hline $1 \mathrm{y}$ & \\
\hline 1, 20041 year $0 \mathrm{~m}$ & $-1.38 \%$ \\
\hline $1 y$ & \\
\hline 061 ye & $-2.21^{\circ}$ \\
\hline . & 0.04 \\
\hline 08 & \\
\hline
\end{tabular}


April 1, 20091 year 0 months

April 1, 20101 year 0 months

April 1, 20111 year 0 months

April 1, 20121 year 0 months

April 1, 20131 year 0 months

April 1, 20141 year 0 months

April 1, 20151 year 0 months

April 1, 20161 year 0 months

April 1, 20171 year 0 months

April 1, 20181 year 0 months

April 1, 20191 year 0 months

April 1, 20201 year 0 months

April 1, 20211 year 0 months

April 1, 20221 year 0 months

April 1, 20231 year 0 months

April 1, 20241 year 0 months

April 1, 20251 year 0 months

April 1, 20261 year 0 months

April 1, 20271 year 0 months

April 1, 20281 year 0 months

April 1, 20291 year 0 months

April 1, 20301 year 0 months

April 1, 2031 Remaining
$1.07 \%$

$1.96 \%$

$1.78 \%$

$2.87 \%$

$3.98 \%$

$2.93 \%$

$2.99 \%$

$3.78 \%$

$2.53 \%$

$2.13 \%$

$3.27 \%$

$3.04 \%$

$2.93 \%$

$2.87 \%$

$2.87 \%$

$2.87 \%$

$2.92 \%$

$2.87 \%$

$2.87 \%$

$2.92 \%$

$2.87 \%$

$2.92 \%$

$2.89 \%$

\section{Component: Existing System}

Comment: Keep existing system for the remaining 15 years of its useful life.

\section{Initial Investment}

Initial Cost Paid By Agency (base-year \$): $\quad \$ 0$

Initial Cost Financed (base-year \$): $\quad \$ 0$

Annual Rate of Increase: $\quad 2.7 \%$

Expected Asset Life: $\quad 15$ years 0 months

Residual Value Factor: $\quad 0 \%$

\section{Cost-Phasing}

Cost Adjustment Factor: $2.7 \%$

Years/Months (from Date) Date Portion

0 years 0 months June 1, $2001 \quad 100 \%$

\section{Recurring OM\&R: OM\&R Cost}

Amount: $\quad \$ 5,600$

Annual Rate of Increase： $2.7 \%$

\section{Usage Indices}

From Date Duration Factor

June 1, 2001 Remaining 100\% 


\section{Alternative: Lighting Retrofit}

\section{Recurring Contract: Annual Contract Payment}

Amount: $\quad \$ 62,000$
Annual Rate of Increase: $\quad 0 \%$

Usage Indices

From Date Duration Factor

June 1, 200110 years 0 months $100 \%$

June 1, $2011 \quad$ Remaining $\quad 0 \%$

Energy: Electricity

Annual Consumption: 206,911.0 kWh

Price per Unit: $\quad \$ 0.04600$

Demand Charge: $\quad \$ 3,311$

Utility Rebate: \$0

Location: Arizona

Rate Schedule: Commercial

State: Arizona

\section{Usage Indices}

From Date Duration Usage Index

June 1, 2001 Remaining 100\%

\section{Escalation Rates}

From Date Duration Escalation

April 1, 20011 year 0 months $\quad-0.6 \%$

April 1, 20021 year 0 months $\quad-0.34 \%$

April 1, 20031 year 0 months $1.51 \%$

April 1, 20041 year 0 months $\quad-1.38 \%$

April 1, 20051 year 0 months $\quad-0.65 \%$

April 1, 20061 year 0 months $\quad-2.21 \%$

April 1, 20071 year 0 months $\quad 0.04 \%$

April 1, 20081 year 0 months $1.64 \%$

April 1, 20091 year 0 months $\quad 1.07 \%$

April 1, 20101 year 0 months $\quad 1.96 \%$

April 1, 20111 year 0 months $1.78 \%$

April 1, 20121 year 0 months $\quad 2.87 \%$

April 1, 20131 year 0 months $3.98 \%$

April 1, 20141 year 0 months $\quad 2.93 \%$

April 1, 20151 year 0 months $\quad 2.99 \%$

April 1, 20161 year 0 months $\quad 3.78 \%$

April 1, 20171 year 0 months $\quad 2.53 \%$

April 1, 20181 year 0 months $2.13 \%$

April 1, 20191 year 0 months $\quad 3.27 \%$

April 1, 20201 year 0 months $\quad 3.04 \%$

April 1, 20211 year 0 months $\quad 2.93 \%$ 
April 1, 20221 year 0 months

April 1, 20231 year 0 months

April 1, 20241 year 0 months

April 1, 20251 year 0 months

April 1, 20261 year 0 months

April 1, 20271 year 0 months

April 1, 20281 year 0 months

April 1, 20291 year 0 months

April 1, 20301 year 0 months

April 1, 2031 Remaining

$$
\begin{aligned}
& 2.87 \% \\
& 2.87 \% \\
& 2.87 \% \\
& 2.92 \% \\
& 2.87 \% \\
& 2.87 \% \\
& 2.92 \% \\
& 2.87 \% \\
& 2.92 \% \\
& 2.89 \%
\end{aligned}
$$

\section{Component: New System}

Comment: Install new lighting/daylighting system financed through UC contract

\section{Initial Investment}

Initial Cost Paid By Agency (base-year \$): $\quad \$ 0$

Initial Cost Financed (base-year \$): $\quad \$ 390,480$

Annual Rate of Increase: $\quad 2.7 \%$

Expected Asset Life: $\quad 20$ years 0 months

Residual Value Factor: $\quad 25 \%$

\section{Cost-Phasing}

Cost Adjustment Factor: $2.7 \%$

Years/Months (from Date) Date Portion

0 years 0 months June 1, $2001 \quad 100 \%$

\section{Recurring OM\&R: Post-Contract OM Costs}

Amount:

$\$ 3,000$

Annual Rate of Increase： $2.7 \%$

Usage Indices

From Date Duration Factor

June 1, 200110 years 0 months $\quad 0 \%$

June 1, 2011 Remaining 100\% 


\section{NIST BLCC 5.0-01: Comparative Analysis}

Consistent with Federal Life Cycle Cost Methodology and Procedures, 10 CFR, Part 436, Subpart A

\section{Base Case: Existing}

\section{Alternative: Lighting Retrofit}

\section{General Information}

File Name:

Run Date:

Project Name:

Project Location:

Analysis Type:

Analyst:

Comment

Base Date of Study:

Service Date:

Study Period:

Discount Rate:

Discounting Convention:
C:\Program Files \BLCC5 $\backslash$ projects $\backslash$ Class Exercise G3.xml

Thu Sep 20 14:33:10 EDT 2001

Class Exercise G3

Arizona

Federal Analysis, Financed Project

ASR

June 1, 2001

June 1, 2001

15 years 0 months(June 1, 2001 through May 31, 2016)

$6.1 \%$

End-of-Year

\section{Comparison of Present-Value Costs}

\section{PV Life-Cycle Cost}

Base Case Alternative Savings from Alternative

Initial Investment Costs Paid By Agency:

Capital Requirements as of Base Date

$\$ 0$

$\$ 0$

$\$ 0$

Future Costs:

Recurring and Non-Recurring Contract Costs

$\$ 0 \quad \$ 454,492$

$-\$ 454,492$

Energy Consumption Costs

$\$ 93,365$

$\$ 395,155$

Energy Demand Charges

$\$ 488,520$

$\$ 32,479$

$\$ 262,834$

Energy Utility Rebates

$\$ 295,313$

$\$ 0$

$\$ 0$

Water Costs

$\$ 0$

$\$ 0$

$\$ 0$

Recurring and Non-Recurring OM\&R Costs

$\$ 65,432$

$\$ 9,847$

$\$ 55,585$

Capital Replacements

Residual Value at End of Study Period

$\$ 0 \quad-\$ 59,988$

$\$ 59,988$

Subtotal (for Future Cost Items)

$\$ 849,264$

$\$ 530,195$

$\$ 319,070$

Total PV Life-Cycle Cost

$\$ 849,264 \$ 530,195$

$\$ 319,070$ 


\section{Net Savings from Alternative Compared with Base Case}

PV of Operational Savings $\$ 713,574$

- PV of Differential Costs $\$ 394,504$

Net Savings $\$ 319,070$

NOTE: Meaningful SIR, AIRR and Payback can not be computed for Financed

Projects.

\section{Comparison of Contract Payments and Savings from Alternative}

(undiscounted)

$$
\text { Savings in Savings in Savings in Savings in }
$$

Year Beginning Contract Costs Energy Costs Total Operational Costs Total Costs

$\begin{array}{lrrrr}\text { Jun 2001 } & -\$ 62,000 & \$ 66,707 & \$ 72,457 & \$ 10,457 \\ \text { Jun 2002 } & -\$ 62,000 & \$ 66,682 & \$ 72,588 & \$ 10,588 \\ \text { Jun 2003 } & -\$ 62,000 & \$ 67,374 & \$ 73,439 & \$ 11,439 \\ \text { Jun 2004 } & -\$ 62,000 & \$ 66,526 & \$ 72,755 & \$ 10,755 \\ \text { Jun 2005 } & -\$ 62,000 & \$ 65,923 & \$ 72,320 & \$ 10,320 \\ \text { Jun 2006 } & -\$ 62,000 & \$ 64,710 & \$ 71,280 & \$ 9,280 \\ \text { Jun 2007 } & -\$ 62,000 & \$ 64,906 & \$ 71,653 & \$ 9,653 \\ \text { Jun 2008 } & -\$ 62,000 & \$ 65,909 & \$ 72,839 & \$ 10,839 \\ \text { Jun 2009 } & -\$ 62,000 & \$ 66,709 & \$ 73,825 & \$ 11,825 \\ \text { Jun 2010 } & -\$ 62,000 & \$ 67,993 & \$ 75,302 & \$ 13,302 \\ \text { Jun 2011 } & \$ 0 & \$ 69,327 & \$ 72,812 & \$ 72,812 \\ \text { Jun 2012 } & \$ 0 & \$ 71,443 & \$ 75,022 & \$ 75,022 \\ \text { Jun 2013 } & \$ 0 & \$ 74,159 & \$ 77,834 & \$ 77,834 \\ \text { Jun 2014 } & \$ 0 & \$ 76,336 & \$ 80,111 & \$ 80,111 \\ \text { Jun 2015 } & \$ 0 & \$ 78,712 & \$ 82,589 & \$ 228,159\end{array}$

\section{Energy Savings Summary}

\section{Energy Savings Summary (in stated units)}

Energy -----Average Annual Consumption----- Life-Cycle

Type Base Case Alternative Savings Savings

Electricity 1,082,633.0 kWh 206,911.0 kWh $875,722.0 \mathrm{kWh} 13,134,031.8 \mathrm{kWh}$

\section{Energy Savings Summary (in MBtu)}

$\begin{array}{lcccc}\text { Energy } & ---- \text { Average } & \text { Annual } & \text { Consumption----- } & \text { Life-Cycle } \\ \text { Type } & \text { Base Case } & \text { Alternative } & \text { Savings } & \text { Savings }\end{array}$

Electricity 3,694.1 MBtu 706.0 MBtu 2,988.1 MBtu 44,815.2 MBtu 


\section{Emissions Reduction Summary}

$\begin{array}{lcccc}\text { Energy } & ---- \text { Average } & \text { Annual } & \text { Emissions----- } & \text { Life-Cycle } \\ \text { Type } & \text { Base Case } & \text { Alternative } & \text { Reduction } & \text { Reduction }\end{array}$

Electricity

CO2 $881,777.18 \mathrm{~kg} 168,523.77 \mathrm{~kg} 713,253.41 \mathrm{~kg} 10,697,336.55 \mathrm{~kg}$

SO2 $\quad 1,080.53 \mathrm{~kg} \quad 206.51 \mathrm{~kg} \quad 874.02 \mathrm{~kg} \quad 13,108.51 \mathrm{~kg}$

NOx $\quad 2,880.63 \mathrm{~kg} \quad 550.54 \mathrm{~kg} \quad 2,330.09 \mathrm{~kg} \quad 34,946.56 \mathrm{~kg}$

Total:

CO2 $881,777.18 \mathrm{~kg} 168,523.77 \mathrm{~kg} 713,253.41 \mathrm{~kg} 10,697,336.55 \mathrm{~kg}$

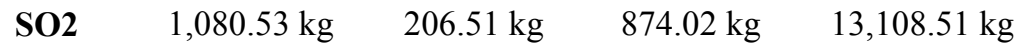

NOx $\quad 2,880.63 \mathrm{~kg} \quad 550.54 \mathrm{~kg} \quad 2,330.09 \mathrm{~kg} \quad 34,946.56 \mathrm{~kg}$ 


\section{Solution to Class Exercise G4}

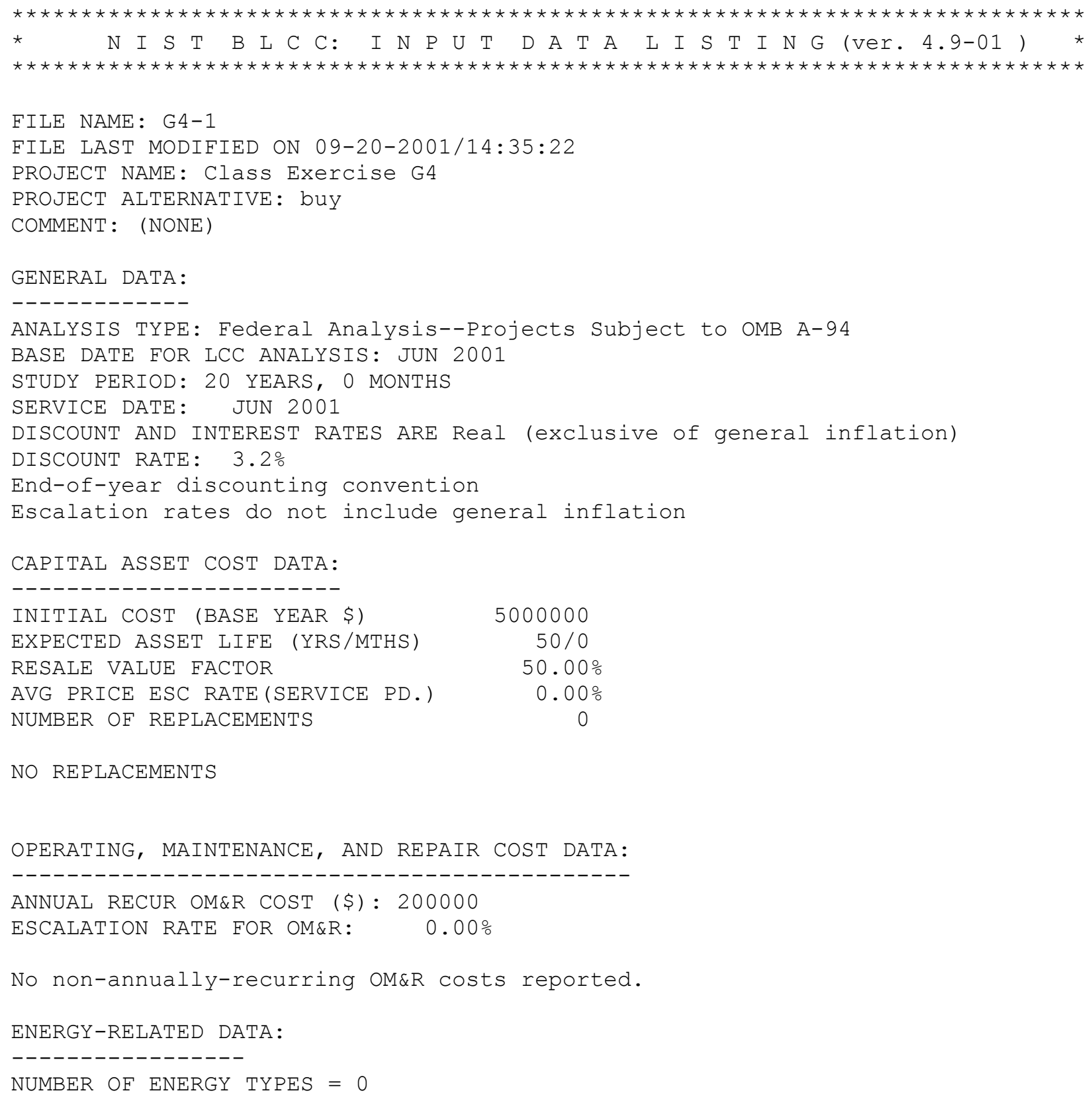

NO REPLACEMENTS

OPERATING, MAINTENANCE, AND REPAIR COST DATA:

---------------------------------------------

ANNUAL RECUR OM\&R COST (\$): 200000

ESCALATION RATE FOR OM\&R: $0.00 \%$

No non-annually-recurring $O M \& R$ costs reported.

ENERGY-RELATED DATA :

NUMBER OF ENERGY TYPES $=0$ 


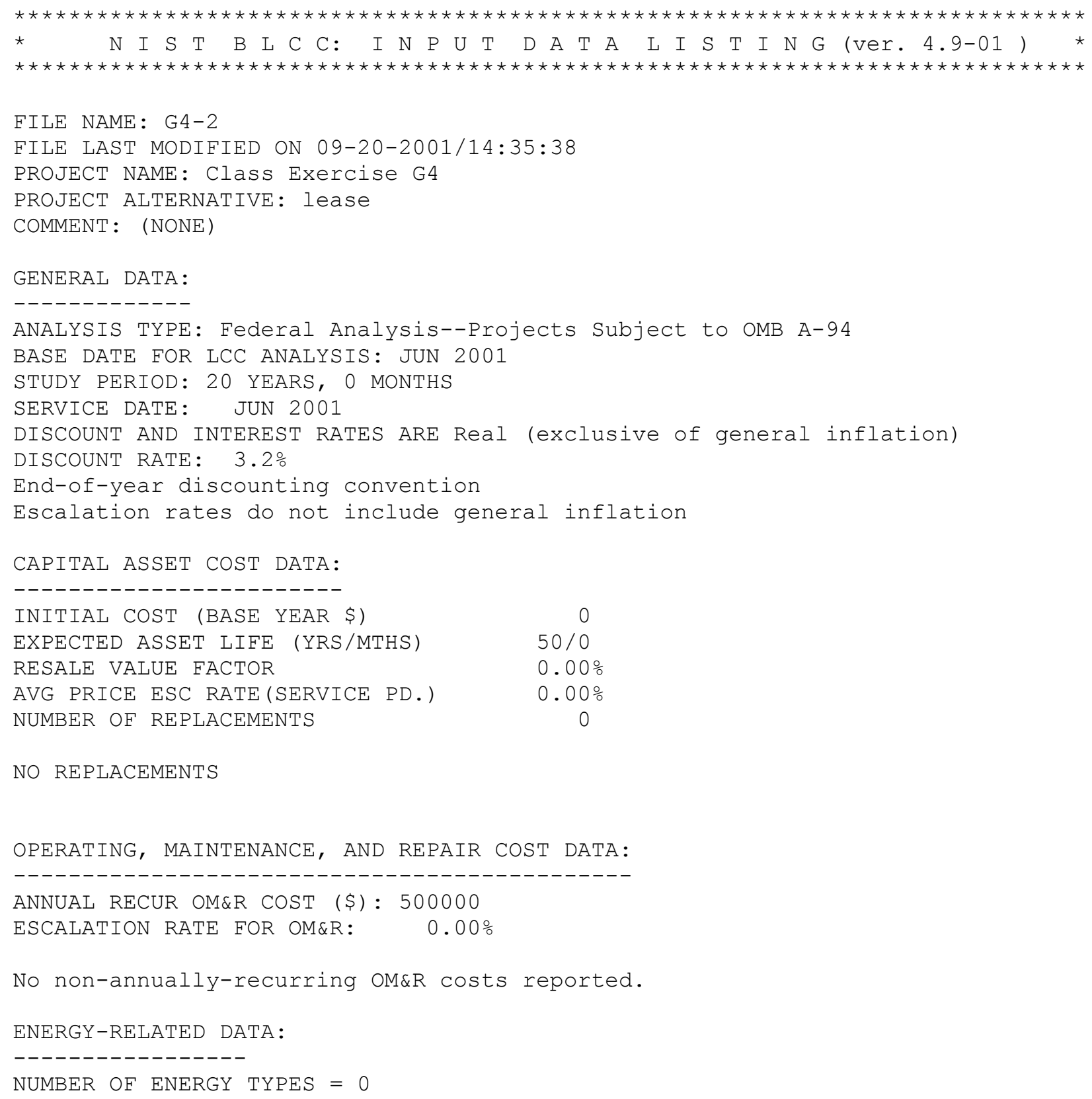


BLCC Summary for Project: Class Exercise G4

Alternative: buy

Filename: G4-1.DAT Date of Analysis: 09-20-2001/14:37:18

Analysis Type: Federal Analysis--Projects Subject to OMB A-94

Study Period: 20.00 Years (JUN 2001 through MAY 2021)

Discount Rate: $3.20 \%$

\begin{tabular}{|c|c|c|}
\hline & Present Value & Annual Value \\
\hline Initial Cost (as of Service Date) & $\$ 5,000,000$ & $\$ 342,324$ \\
\hline Annually Recurring OM\&R Costs & $\$ 2,921,209$ & $\$ 200,000$ \\
\hline Less: Remaining Value & $\$ 1,331,516)$ & $\$ 91,162)$ \\
\hline-------------------------------------- & ------------ & ------------ \\
\hline Total LCC & $\$ 6,589,693$ & $\$ 451,162$ \\
\hline
\end{tabular}

BLCC Summary for Project: Class Exercise G4

Alternative: lease

Filename: G4-2.DAT Date of Analysis: 09-20-2001/14:37:30

Analysis Type: Federal Analysis--Projects Subject to OMB A-94

Study Period: 20.00 Years (JUN 2001 through MAY 2021)

Discount Rate: $3.20 \%$

\begin{tabular}{|c|c|c|}
\hline & Present Value & Annual Value \\
\hline Initial Cost (as of Service Date) & $\$ 0$ & $\$ 0$ \\
\hline Annually Recurring OM\&R Costs & $\$ 7,303,022$ & $\$ 500,000$ \\
\hline Less: Remaining Value & $\$ 0)$ & $\$ 0)$ \\
\hline 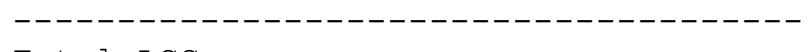 & ----------- & ------------ \\
\hline Total LCC & $\$ 7,303,022$ & $\$ 500,000$ \\
\hline
\end{tabular}




\section{Economic Measures of Evaluation and Their Uses}

\begin{tabular}{|c|c|c|c|c|c|}
\hline \multirow{2}{*}{ Type of Decision } & \multicolumn{5}{|c|}{ Appropriate LCC Economic Measures (Evaluation Criterion) } \\
\hline & $\mathrm{LCC}$ & NS & SIR & AIRR & DISCOUNTED PB \\
\hline Accept/Reject & $\begin{array}{c}\text { yes } \\
\text { (minimum) }\end{array}$ & $\begin{array}{l}\text { yes } \\
(>0)\end{array}$ & $\begin{array}{c}\text { yes } \\
(>1.0)\end{array}$ & $\begin{array}{c}\text { yes } \\
(>\text { discount rate) }\end{array}$ & $\begin{array}{c}\text { conditional }^{*} \\
(<\text { or }=\text { study period })\end{array}$ \\
\hline Level of Efficiency & $\begin{array}{c}\text { yes } \\
\text { (minimum) }\end{array}$ & $\begin{array}{c}\text { yes } \\
\text { (maximum) }\end{array}$ & no & no & no \\
\hline System Selection & $\begin{array}{c}\text { yes } \\
\text { (minimum) }\end{array}$ & $\begin{array}{c}\text { yes } \\
\text { (maximum) }\end{array}$ & no & no & no \\
\hline $\begin{array}{c}\text { Combination of } \\
\text { Interdependent Systems }\end{array}$ & $\begin{array}{c}\text { yes } \\
\text { (minimum combined } \\
\text { LCC) }\end{array}$ & $\begin{array}{c}\text { yes } \\
\text { (maximum combined } \\
\text { NS) }\end{array}$ & no & no & no \\
\hline $\begin{array}{c}\text { Project Priority } \\
\text { (Independent Projects) }\end{array}$ & no & no & $\begin{array}{c}\text { yes } \\
\text { (descending order)** }\end{array}$ & $\begin{array}{c}\text { yes } \\
\text { (descending order)** }\end{array}$ & no \\
\hline
\end{tabular}

* Discounted Payback measure is consistent with LCC only if (1) cumulative net savings after payback is reached do not turn negative, and (2) residual values, if any, are included if payback is $>$ or $=$ study period.

** Fund in descending order of SIR or AIRR until budget is exhausted. Group of projects that fits within budget and has greatest overall net savings is best. 



\title{
Acronyms
}

\author{
AIRR \\ Adjusted Internal Rate of Return \\ BOA \\ Basic Ordering Agreement \\ Btu \\ British Thermal Units \\ DoD \\ Department of Defense \\ DOE \\ Department of Energy \\ DPB \\ Discounted Payback \\ ECM \\ Energy Conservation Measure \\ ESCO \\ ESPC \\ Energy Services Company \\ FEMP \\ Federal Energy Management Programs \\ HVAC \\ Heating, Ventilation, and Air Conditioning \\ GJ \\ kWh \\ Gigajoule ( $10^{9}$ joules $)$ \\ Kilowatt Hours \\ LCC \\ Life-Cycle Costs or Life-Cycle Costing \\ MBtu \\ MBtu $\left(10^{6} \times\right.$ Btu $)$ \\ NS \\ OM\&R \\ Net Savings \\ OMB \\ Operation, Maintenance, and (Routine) Repairs \\ PB \\ Office of Management and Budget \\ $\mathrm{P} / \mathrm{C} / \mathrm{I}$ \\ Payback \\ SIR \\ Planning/Contructions or Installation Period \\ Savings-to-Investment Ratio \\ SPB \\ Simple Payback
}




\author{
SPV \\ TLCC \\ Single Present Value (Factor) \\ Total Life-Cycle Costs \\ UC or UESC \\ Utility Contract or Utility Energy Services Contract \\ UPV \\ Uniform Present Value (Factor) \\ UPV* \\ Modified Uniform Present Value (Factor)
}




\section{Glossary}

\section{Adjusted Internal Rate of Return (AIRR)}

Annual yield from a project over the Study Period, taking into account investment of interim amounts.

\section{Alternative Building System}

An installation or modification of an installation in a building intended primarily to reduce energy or water consumption or allow the use of renewable energy sources, or a primarily energy- or water-saving building system, including a renewable energy system, for consideration as part of the design for a new federal building.

\section{Amount Financed}

Includes Implementation Costs and usually Financing Procurement Costs to comprise the amount borrowed by the Government agency to implement energy conservation measures.

\section{Annually Recurring Costs}

Those costs incurred each year in an equal, constant dollar amount throughout the Study Period, or that change from year to year at a known rate.

Annual Value (Annual Worth)

The time-equivalent value of past, present, or future cash flows expressed as an Annually Recurring Uniform amount over the Study Period.

\section{Annual Value (Annual Worth or Uniform Capital Recovery) Factor}

A discount factor by which a present dollar amount may be multiplied to find its equivalent Annual Value, based on a given Discount Rate and a given period of time.

\section{Base Case}

The situation against which an Alternative Building System is compared.

\section{Base Date}

The beginning of the first year of the Study Period, generally the date on which the Life-

\section{Base Year}

Cycle Cost analysis is conducted.

The first year of the Study Period, generally the year in which the Life-Cycle Cost analysis is conducted.

\section{Base-Year Energy Costs}

The quantity of energy delivered to the boundary of a Federal Building in the Base Year, multiplied by the Base-Year Price of fuel.

\section{Base-Year Price}

\section{Cash Flow}

The price of a good or service as of the Base Date.

The stream of costs and benefits (expressed for the purpose of this requirement in Constant Dollars) resulting from a project investment.

\section{Compound Interest Factors or Formulas}

See Discount Factors or Formulas.

\section{Constant Dollars}

Dollars of uniform purchasing power tied to a reference year (usually the Base Year) and exclusive of general price inflation or deflation.

\section{Contract Payments}

An agreed-upon payment made annually or non-annually by the agency to repay the loan provided by an ESCO or UC for implementing energy savings measures. 


\section{Contract Period or Contract Term}

The time period proposed by the contractor for repaying the loan provided to a Government agency to implement energy savings measures. It begins at the contract award date and includes the Installation Period and the Energy Savings Performance Period.

\section{Cost Adjustment Factor}

The average annual rate at which the phased-in cost of a capital component is adjusted to its value in any year of the Planning/Construction/Installation Period. The Cost Adjustment Factor can, for example, be a contractual rate (sometimes equal to zero) or a rate determined by the agency.

\section{Cost Effective}

The condition whereby an Alternative Building System saves more than it costs over the Study Period, where all Cash Flows are assessed in Constant Dollars and discounted to reflect the Time Value of Money.

\section{Current Dollars}

Dollars of nonuniform purchasing power, including general price inflation or deflation, in which actual prices are stated. (With zero inflation or deflation, current dollars are identical to constant dollars.)

\section{Debt Service}

The sum of interest payments and principal payments which comprise or are part of the Contract Payment to an ESCO or UC.

\section{Demand Charge}

That portion of the charge for electric service based on the plant and equipment costs associated with supplying the electricity consumed.

\section{Differential Cost}

The difference in the costs of an Alternative Building System and the Base Case.

\section{Differential Energy Price Escalation Rate}

The difference between a projected general rate of Inflation and the projected rate of price increase assumed for energy.

\section{Discount Factors}

Multiplicative numbers used to convert Cash Flows occurring at different times to their equivalent amount at a common time. Discount factors are obtained by solving Discount Formulas based upon one dollar of value and an assumed Discount Rate and time.

\section{Discount Formula}

An expression of a mathematical relationship which enables the conversion of dollars at a given point in time to their equivalent amount at some other point in time.

\section{Discount Rate}

The rate of interest, reflecting the investor's Time Value of Money (or opportunity cost), that is used in Discount Formulas or to select Discount Factors which in turn are used to convert ("discount") Cash Flows to a common time. Real Discount Rates reflect Time Value of Money apart from changes in the purchasing power of the dollar and are used to discount Constant Dollar Cash Flows; Nominal Discount Rates include changes in the purchasing power of the dollar and are used to discount Current Dollar Cash Flows.

\section{Discounted Payback Period}

The time required for the cumulative savings from an investment to pay back the Investment Costs and other accrued costs, taking into account the Time Value of Money. 


\section{Discounting}

A technique for converting Cash Flows occurring over time to time-equivalent values, at a common point in time, adjusting for the Time Value of Money.

\section{Disposal Cost}

See Residual Value.

\section{Economic Life}

That period of time over which a Building or Building System is considered to be the lowestcost alternative for satisfying a particular need.

\section{Energy Conservation Measure (ECM)}

Defined as the installation of new equipment/facilities, modification, or alteration of existing government equipment/facilities, or revised operations and maintenance procedures to reduce energy consumption of facilities/energy systems.

\section{Energy Cost}

The annual cost of fuel or energy used to operate a building or building system, as billed by the utility or supplier (including Demand Charges, if any). Energy Costs are incurred during the Service Period only. Energy consumed in the construction or installation of a new building or building system is not included in this cost.

\section{Energy Savings Performance Contracts}

Contracts authorized by the Energy Policy Act of 1992 (EPACT), which offer alternative financing of energy and water efficiency improvements in federal buildings and allow the Federal Government to retain a portion of the energy savings and all equipment installed.

\section{Energy Savings Performance Period (ESPC)}

The period (typically in years) from the date an ECM is operational and accepted by the Government agency to the end of the Contract Period. The Energy Savings Performance Period may also be referred to as the "service period."

\section{Federal Government}

The U.S. Government.

\section{Financing Procurement Costs}

May be added to Implementation Costs to comprise the total amount financed by an ESCO or $\mathrm{UC}$.

\section{Future Value}

The time-equivalent value of past, present, or future Cash Flows expressed as of some future point in time.

\section{Implementation Costs}

May include survey costs, feasibility study costs, design expenses, and construction costs, which may be paid by an agency or included in the Contract Payment proposed by ESCO or UC.

\section{Initial Investment Costs}

The initial costs of design, engineering, purchase, and installation, exclusive of "Sunk Costs," all of which are assumed to occur as a lump sum at the beginning of the Base Year or during the Planning/Construction/Installation Period for purposes of making the life-cycle cost analysis.

\section{Inflation}

A rise in the general price level, or, put another way, a decline in the general purchasing power of the dollar. 


\section{Installation Period}

The period from the date of contract award to the date all contracted energy conservation measures are operational and accepted by the agency. Installation period may also be referred to as "construction period."

Internal Rate of Return

Annual yield from a project over the Study Period, i.e., the compound rate of interest which, when used to discount Cash Flows of an Alternative Building System, will result in zero Net Savings (Net Benefits).

\section{Life-Cycle Cost (LCC)}

The total discounted dollar costs of owning, operating, maintaining, and disposing of a building or building system over the Study Period (see Life-Cycle Cost Analysis).

\section{Life-Cycle Cost Analysis (LCCA)}

A method of economic evaluation that sums discounted dollar costs of initial investment (less Resale, Retention, or Salvage Value), replacements, operations (including energy and water usage), and maintenance and repair of a building or building system over the Study Period (see Life-Cycle Cost). Also, as used in this program, LCCA is a general approach to economic evaluation encompassing several related economic evaluation measures, including Life-Cycle Cost (LCC), Net Benefits (NB) or Net Savings (NS), Savings-to-Investment Ratio (SIR), and Adjusted Internal Rate of Return (AIRR), all of which take into account long-term dollar impacts of a project.

\section{Liquid Petroleum Gas (LPG)}

Propane, butane, ethane, pentane, or natural gasoline.

\section{Market Interest Rate}

The nominal loan interest rate (including inflation) applied by the ESCO or UC to the Amount Financed to compute annual Contract Payments.

\section{Measures of Economic Evaluation}

The various ways in which project cash flows can be combined and presented to describe a measure of project cost effectiveness. The measures used to evaluate FEMP projects are LifeCycle Cost (LCC), Net Savings (NS), Savings-to-Investment Ratio (SIR), Adjusted Internal Rate of Return (AIRR). Discounted Payback (DPB) and Simple Payback (SPB) are measures of evaluation not fully consistent with the LCC method but are used as supplementary measures in some federal programs.

\section{Modified Uniform Present Value (Worth) (UPV* or UPW*) Factor}

A discount factor used to convert an annual amount escalating at a constant rate to a timeequivalent Present Value. The FEMP UPV* Factor indicates a discount factor from a special set published by the U.S. Department of Energy, Federal Energy Management Program, for computing present value energy costs based on variable energy price projections.

\section{Mutually Exclusive Projects}

Projects where the acceptance of one precludes acceptance of the others. Examples are whether to use single-glazing, double-glazing or triple-glazing for a window; or R11, R19, or R30 levels of insulation in an attic.

\section{Net Savings (Net Benefits)}

Time-adjusted savings (or benefits) less time-adjusted differential costs taken over the Study Period for an Alternative Building System relative to the base case.

\section{Nominal Discount Rate}

The rate of interest (market interest rate) reflecting the time value of money stemming from both inflation and the real earning power of money over time. 


\section{Nonmutually Exclusive Projects}

Projects where the acceptance of one alternative does not preclude the acceptance of the others. Examples are wall insulation and ceiling insulation.

\section{Nonrecurring Costs}

Costs that are not uniformly incurred annually over the Study Period.

\section{Nonfuel Operation, Maintenance, and Repair (OM\&R) Costs}

Labor and material costs required for routine upkeep, repair, and operation, exclusive of energy costs.

\section{Nonmutually Exclusive Projects}

Projects where the acceptance of one does not preclude the acceptance of the others. Examples are wall insulation and ceiling insulation. (For contrast, see Mutually Exclusive.)

\section{Performance Period Expenses}

May include management/administration costs, operation and maintenance costs, repair and replacement costs, measurement and verification costs, permits and licenses costs, insurance costs, property taxes, and other costs (e.g., "margin"), which may be paid by agency or included in the Contract Payment proposed by ESCO or UC.

\section{Planning/Construction Period}

The period beginning with the Base Date and continuing up to the Service Date, during which only Initial Investment Costs are incurred.

\section{Post-Contract Period}

The period between the end of the Contract Period (Contract Term) and the end of the Study Period.

\section{Present Value (Present Worth)}

The time-equivalent value of past, present or future Cash Flows as of the beginning of the Base Year.

\section{Present Value (Present Worth) Factor}

A discount factor by which a future dollar amount may be multiplied to find its equivalent Present Value as of the Base Date. Single Present Value Factorsare used to convert single future amounts to Present Values. Uniform Present Value Factors and Modified Present Value Factors are used to convert Annually Recurring amounts to Present Values.

\section{Real Discount Rate}

The rate of interest reflecting the portion of the time value of money attributable to the real earning power of money over time and not to general price inflation.

\section{Renewable Energy}

Energy obtained from sources that are essentially inexhaustible (unlike, for instance, fossil fuels of which there is a limited supply). Renewable sources of energy include wind energy, geothermal energy, hydroelectric energy, photovoltaic and solar energy, biomass, and waste.

\section{Replacement Costs}

Future costs included in the capital budget to replace a building system during the Study Period.

\section{Resale Value}

See Residual Value.

\section{Residual Value}

The estimated value, net of any Disposal Costs, of any building or building system removed or replaced during the Study Period; or remaining at the end of the Study Period; or recovered through resale or reuse at the end of the Study Period (also called Resale Value or Salvage Value, or Retention Value). 


\section{Retention Value}

\section{Retrofit}

See Residual Value.

The installation of an Alternative Building System in an Existing Federal Building.

\section{Risk Attitude}

The willingness of decision makers to take chances or to gamble on investments of uncertain

Risk Exposure outcome. Risk attitudes are generally classified as risk-averse, risk-neutral, or risk-taking.

The probability of investing in a project whose economic outcome is less favorable than what is economically acceptable.

\section{Salvage Value}

See Residual Value.

\section{Savings-to-Investment Ratio (SIR)}

A ratio computed from a numerator of discounted energy and/or water savings, plus (less) savings (increases) in Nonfuel Operation and Maintenance Costs, and a denominator of increased Investment Costs plus (less) increased (decreased) Replacement Costs, net of Residual Value (all in present-value terms), for an Alternative Building System as compared with a Base Case.

\section{Sensitivity Analysis}

Testing the outcome of an evaluation to changes in the values of one or more system parameters from the initially assumed values.

\section{Service Date}

The point in time during the Study Period when a building or building system is put into use, and operating, maintenance, and repair costs (including energy and water costs) begin to be incurred.

\section{Service Period}

The period of time starting with the Service Date and continuing through the end of the Study Period.

\section{Simple Payback Period (SPB)}

A measure of the length of time required for cumulative savings from a project to recover the Investment Cost and other accrued costs, without taking into account the Time Value of Money.

\section{Single Present Value (Worth) (SPV or SPW) Factor}

The discount factor used to convert single future benefit and cost amounts to Present Value.

\section{Study Period}

The length of the time period covered by the economic evaluation. This includes both the

\section{Sunk Costs} Planning/Construction Period and the Service Period.

Costs which have been incurred or committed to prior to the Life-Cycle Cost analysis and which, therefore, should not be considered in making a current project decision since the costs cannot be changed.

\section{Time-of-Use Rate}

The charge for service during periods of the day based on the cost of supplying the service at that particular time of the day.

\section{Time Value of Money}

The time-dependent value of money. If project Cash Flows are stated in Constant Dollars, their adjustment to a common time basis is necessary to take into account the real earning potential of investments over time. If project cash flows are stated in Current Dollars, their 
adjustment to a common time basis is necessary to take into account not only the real earning potential over time, but also price inflation or deflation.

\section{Uniform Present Value (Worth) (UPV or UPW) Factor}

The discount factor used to convert uniform annual values to a time-equivalent Present Value.

\section{Useful Life}

The period of time over which a Building or Building System continues to generate benefits or savings.

\section{Utility Contracts (UC) or Utility Energy Services Contracts (UESC)}

Contracts (Area-Wide Contracts or Basic Ordering Agreements) between a government agency and a utility company, which allow the Federal Government to implement energy and water conservation measures through financing provided by the utility. 



\section{COURSE EVALUATION}

PURPOSE: It is our objective to present a useful and effective training course. You are the final authority on whether that objective has been met. Your completion of this form, therefore, will play an important part in our future planning. Please do not feel bound to limit your remarks to questions on this form. Your comments on any aspect of the course will be appreciated.

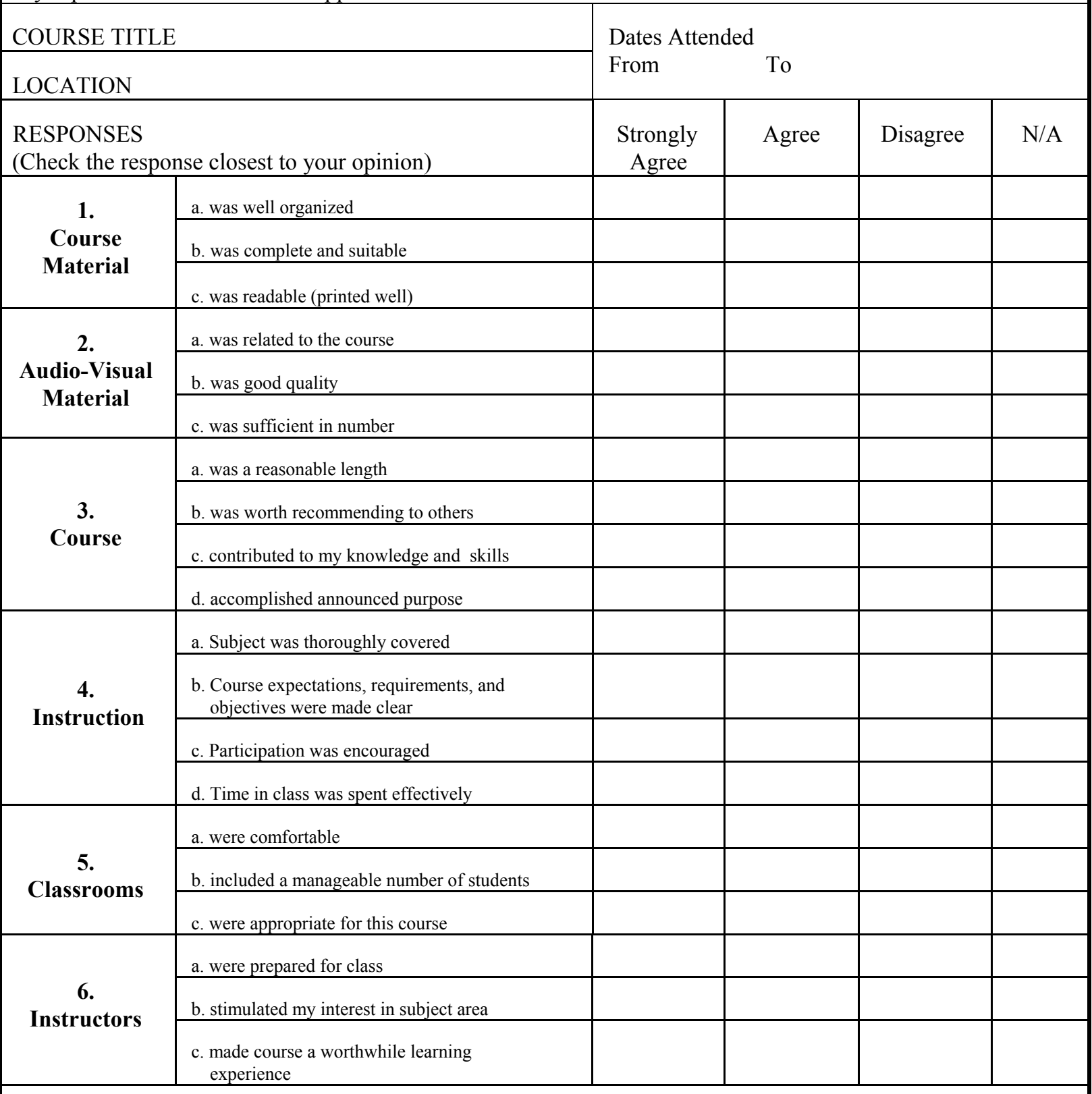

REMARKS: 
COURSE EVALUATION (Continued)

7. OVERALL INSTRUCTOR EVALUATION (Check your opinion)

a. Knowledge of the subject $\square$ Excellent $\square$ Good $\square$ Fair $\square$ Poor

b. Ability to teach $\square$ Excellent $\square$ Good $\square$ Fair $\square$ Poor

8. WOULD YOU ADD OR EMPHASIZE ANY SUBJECT MATTER AREAS IN SUBSEQUENT COURSE SESSIONS?

$\square$ yes $\square$ no If "yes," list these areas and give your reasons:

9. WOULD YOU DELETE OR DE-EMPHASIZE ANY SUBJECT-MATTER AREAS?
$\square$ yes
$\square$ no
If "yes," list these areas and give your reasons:

10. AS A RESULT OF YOUR PARTICIPATION IN THIS COURSE, WHAT ADDITIONAL RELATED

TRAINING SHOULD BE MADE AVAILABLE?

11. OTHER COMMENTS. PLEASE MAKE ANY COMMENTS RELATIVE TO THIS COURSE, EITHER GENERAL OR SPECIFIC. 